$$
\text { UNIVERSIDADE DE SÃO PAULO }
$$

FACULDADE DE FILOSOFIA, LETRAS E CIÊNCIAS HUMANAS PROGRAMA DE PÓS-GRADUAÇÃO EM ANTROPOLOGIA SOCIAL

\title{
Distinções eyiguayegui
}

\author{
Versão Corrigida
}

São Paulo

2018 


\title{
GABRIELA DE CARVALHO FREIRE
}

\section{Distinções eyiguayegui}

\author{
Versão Corrigida
}

Dissertação de Mestrado apresentada ao Programa de PósGraduação em Antropologia Social da Faculdade Filosofia, Letras e Ciências Humanas da Universidade de São Paulo como parte dos requisitos para obtenção do título de Mestre em Antropologia Social.

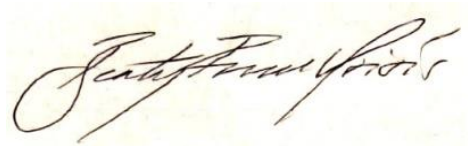

Orientadora: Prof ${ }^{a}$. Dra ${ }^{a}$. Beatriz Perrone-Moisés

São Paulo 
FREIRE, Gabriela de Carvalho. Distinções eyiguayegui. Dissertação de Mestrado. Programa de Pós-Graduação em Antropologia Social. Faculdade de Filosofia, Letras e Ciências Humanas da Universidade de São Paulo (USP). São Paulo, 2018, 216 p.

Aprovada em:

Banca Examinadora:

Prof. Dr. Spensy Kmitta Pimentel (Instituto de Humanidades, Artes e Ciências Universidade Federal do Sul da Bahia).

Julgamento: Assinatura:

Prof. Dr. Antônio Roberto Guerreiro Junior (Departamento de Antropologia - Universidade de Campinas).

Julgamento: Assinatura:

Prof. Dr. Renato Sztutman (Departamento de Antropologia - Universidade de São Paulo). Julgamento: Assinatura: 
À Lilian Rose, minha mãe e fonte de toda a inspiração. 


\section{Agradecimentos}

Idealizar, planejar, escrever e, finalmente, revisar uma dissertação é uma empreitada que dura muito mais de dois anos e meio. No meu caso, ela começou por volta dos meus dezesseis anos quando eu, aflita por me livrar dos pressupostos que fundamentavam a "educação bancária" que me foi oferecida desde criança por uma escola financiada por um dos maiores bancos do Brasil, decidi que era meu objetivo cortar todas essas amarras por meio da dedicação ao conhecimento. A jornada terminou mais de dez anos depois, e o resultado é fruto das mudanças e impermanências que me acompanharam durante esse período.

No esforço de voltar ao início, percebi que meus agradecimentos precisam começar pela pessoa que me ajudou a questionar, desde os treze anos, tudo o que estava à minha volta. Francine Souza, sem você e sem nossas discussões (e revoltas) adolescentes acerca do "sistema", dos problemas do mundo, da vida, esse mestrado não teria sido tão sonhado e desejado e, enfim, finalmente se realizado.

O questionamento de cada premissa, detalhe e situação, tão característica da minha personalidade e, espero, deste trabalho, é resultado da educação (totalmente contrária àquela "bancária") que recebi em casa. Agradeço ao meu pai, Alair Freire, pela confiança que depositou em mim desde sempre, ainda que eu tenha seguido caminhos tão diferentes dos seus. Ao meu irmão, Júlio César, por todo o amor, a compreensão e o ombro amigo quando eu mais precisei. À minha mãe devo um agradecimento especial: obrigada por ter me inspirado, desde que me entendo por gente, a procurar por algo maior do que eu e a realidade à minha volta e, ao mesmo tempo, por me fazer acreditar em mim mesma e no meu "jeito" que, afinal, "é o jeito certo". A você devo o traço marcante desse trabalho, o incessante questionamento e a procura do porquê de todas as coisas. Obrigada aos três por fazerem possível a realização da pesquisa.

Agradeço também às mulheres da minha família, que me ensinaram, desde quando eu era criança, a perseguir meus objetivos com todas as forças que pudesse reunir. As páginas seguintes são apenas mais outras que se somam a uma história escrita por todas vocês (avós, tias, primas e mãe), todas elas repletas de sonhos e perseverança. Obrigada por me ensinarem que os limites impostos a nós mulheres podem ser ultrapassados quando persistimos. Um agradecimento especial à minha tia Eliziane Carvalho, que me ajudou com o abstract e com quem tenho dividido tantos interesses ultimamente. 
Ao meu avô, Antônio Roque, e à minha avó, Maria da Conceição, agradeço pelas tardes que passamos juntos nesses anos e o cuidado que sempre me dedicaram. Ouvir suas histórias, suas risadas, sentir sua confiança em mim foi parte decisiva neste processo.

Desde meu planejamento inicial, passando pelo momento em que a pesquisa começou a ser gestada, pelo final da graduação e início do mestrado, muitas pessoas passaram e todas contribuíram, direta ou indiretamente, para este resultado final. À Fernanda Verzinhassi agradeço pelos anos que dividimos, pela alegria quando passei na prova teórica, na prova de línguas e na entrevista - todo esse processo teria sido muito pior sem você. Pelo esforço conjunto de compreensão uma da outra, pelas viagens, pelos questionamentos... Continuo afirmando que você tem alma de antropóloga, ainda que não goste de Antropologia.

Aos amigos da graduação que continuo encontrando no bar: obrigada à Maraiza Adami por inspirar a todas com sua determinação e família maravilhosa; à Roberta Novello pelas tardes na rede ouvindo Janis Joplin, Billie Holiday e Nina Simone; à Izabela Nalio, com quem compartilho o mesmo local de nascimento, a mesma escola, a mesma faculdade e muito carinho; ao Rafael Tannus pelas paradas (salvadoras) para o café em meio à escrita; ao Rafael Pacheco por me abrigar em sua casa, me apresentar uma Curitiba maravilhosa e misturar etnologia com cerveja; e ao Igor Costa pela força compartilhada em momentos complicados, pelos desabafos de ambos os lados e pela amizade imprevista.

Todo o meu amor à Marina Macedo Rego e Danielle Sousa, com quem vivi histórias épicas e, com certeza, as melhores viagens. Sinto-me privilegiada por ter em minha vida histórias de amizade tão bonitas quanto as nossas, sempre compostas por sentimentos intensos. Vocês são parte inalienável de mim e fico extremamente feliz de poder dedicar-lhes meus mais sinceros agradecimentos, mesmo depois de anos conturbados. Obrigada pelo esforço de compreensão e por compartilharem suas vidas e crescimento comigo.

Agradeço imensamente por ter encontrado, nos colegas e amigos da Sala 26, a força que buscava nos momentos em que a escrita parecia não se desenvolver: nossas conversas fora de hora fizeram toda a diferença e me ajudaram a seguir em frente. Meus agradecimentos ao Bernardo Machado, sempre pronto para nos ajudar com referências, pen drives e palavras confortantes; à Aline Murillo que faz a Antropologia ficar mais bonita e inspira a todos quando fala com paixão de sua pesquisa; à Paula, mulher incansável que trouxe seu dinamismo e sensibilidade para seu trabalho, para as reuniões da Cadernos de Campo e para o Butantã (pelo menos temporariamente), e ao Rafael Quintanilha pelas piadas de araque.

Ao Lucas Ramiro e ao Frank Nabeta, do CEstA, agradeço pelo período em que trabalhamos juntos, pelos workshops de photoshop e pelas horas ouvindo Wendy Sulca. 
Obrigada também aos amigos pesquisadores do CEstA que tanto me ensinaram quanto me fizeram rever diversos pontos cruciais da pesquisa. Agradeço ao Augusto Ventura pelas conversas sempre agradáveis nas tardes do CEstA; ao Leonardo Braga pelo (quase-)abrigo em Santarém; à Larissa Barcellos pelas angústias compartilhadas e gosto musical duvidoso; ao Fernando Fileno pela companhia imprevista nos congressos; e à Raquel Duran, companheira nos estudos sobre os Kadiwéu. À Ana Yano e ao André Drago devo um agradecimento mais do que especial: desde o início da escrita do projeto até o final da dissertação tive em vocês amigos e mestres imprescindíveis. Muito obrigada pelas leituras, críticas, discussões e áudios de whatsapp, essa dissertação está fundamentada no conhecimento que vocês e a Bia me transmitiram ao longo desses anos. À Beatriz PerroneMoisés agradeço por confiar naquela menina de 19 anos encantada pelos escritos clastreanos e por fazê-la se (re-)encantar, de novo e de novo, pela antropologia, além de ensiná-la a ouvir seus dados antes de qualquer teoria. Finalmente, meus agradecimentos aos Professores Renato Sztutman, Antônio Guerreiro e Spensy Pimentel, que constituíram minha banca e contribuíram com valiosos comentários.

À minha turma de mestrado agradeço pelas trocas proporcionadas nas discussões do primeiro ano da nossa formação. Ao Henrique Pougy e Bruno Ribeiro, à Aline Aranha e Carolina Mazzarielo, agradeço não apenas pelas discussões acadêmicas, mas também os momentos que compartilhamos fora da USP. À Renata Cortez agradeço especialmente os comentários na disciplina de Metodologia de Projetos. Ao Gustavo Berbel agradeço pela poesia em cada encontro; à Mari Machini pelo carinho presente em cada ato e que acaba nos contagiando; ao Lucas Bulgarelli pela comida maravilhosa e cumplicidades escorpianas; e ao Artur Fontgaland, ou Caipora, pela doçura na fala e no olhar e pela escuta sempre atenta.

O mestrado me presenteou com dois irmãos que me ensinaram não apenas sobre Antropologia, mas também sobre a vida. Ao Rafael Hupsel agradeço não só as risadas, o companheirismo nas comissões da Cadernos e as conversas durante a escrita, mas também todas as reflexões que me estimularam a seguir caminhos diferentes. Ao Hélio Menezes, cuja genialidade (que já é muita) não é nada perto da grandiosidade de sua alma, gostaria de agradecer todos os conselhos, os puxões de orelha, os incentivos, as noites na varanda e todo o amor. Muito obrigada aos dois, que ajudaram a transformar o mestrado em um período tão rico.

Por fim, agradeço ao Diogo Maciel, que está presente em todas as linhas deste trabalho. Obrigada por dar vida ao que eu achei que já tinha morrido, por escutar o que fazia tempo que eu mesma não ouvia, por criar comigo um cotidiano de valetes e indecisões, e por contar comigo sempre. Assim como nessa dissertação, em você está o fruto de todas as 
transformações que vivi. Agradeço, com amor, por todas as revisões, todas as horas ouvindo sobre o Chaco e todas as conversas reconfortantes.

Agradeço, por último, à CAPES, que me concedeu uma bolsa para o mestrado, permitindo que eu me dedicasse integralmente à pesquisa. 
FREIRE, Gabriela de Carvalho. Distinções eyiguayegui. Dissertação de Mestrado. Programa de Pós-Graduação em Antropologia Social. Faculdade de Filosofia, Letras e Ciências Humanas da Universidade de São Paulo (USP). São Paulo, 2018, 216 p.

\section{Resumo}

A dissertação pretende contribuir num esforço mais amplo de revisão do que tem sido comumente identificado como organização hierárquica nas Américas. Trata-se de explorar os desafios colocados pela suposta hierarquia eyiguayegui/kadiwéu: escravos tratados com carinho e que não são obrigados ao trabalho, servos voluntários, populações tributárias que recebem presentes de seus senhores, capitães que não comandam, estatutos hereditários que se ganha ou se perde à força do caráter e das habilidades, mulheres guerreiras, homens cantores e uma estratificação social aparentemente em tudo análoga à da Europa feudal, mas na qual até escravos podiam ascender à posição de nobre, ou de capitão. Partindo desse panorama construído pela literatura especializada, o trabalho analisa, à luz das reflexões atuais da etnologia americanista, os dados trazidos pela documentação colonial e pelas etnografias de modo a esmiuçar (e questionar) a construção de um regime epistêmico que lê as relações eyiguayegui/kadiwéu como baseadas em uma hierarquia e em uma separação entre o "doméstico" e o "político". O exame minucioso destes dados levou à indagação de vários termos utilizados, ao longo dos séculos, nas descrições das relações políticas eyiguayegui/kadiwéu, como "escravidão", "trabalho”, "servidão”, "simbiose”, "propriedade”, "estratificação social" e a própria ideia de "hierarquia". Esse questionamento levou, enfim, à reflexão acerca da construção dos corpos eyiguayegui e, consequentemente, daquilo que denomino distinções ou diferenciações entre as pessoas eyiguayegui.

\section{Palavras-chave}

Etnologia ameríndia; Gran Chaco; Eyiguayegui; Kadiwéu; Hierarquia. 
FREIRE, Gabriela de Carvalho. Eyiguayegui distinctions. Dissertação de Mestrado. Programa de Pós-Graduação em Antropologia Social. Faculdade de Filosofia, Letras e Ciências Humanas da Universidade de São Paulo (USP). São Paulo, 2018, 216 p.

\begin{abstract}
The dissertation aims to contribute to a broader review effort of what has been commonly identified as hierarchical organisation in the Americas. It is a question of exploring the challenges posed by the supposed eyiguayegui/kadiwéu hierarchy: slaves treated with affection and who are not forced to work; voluntary servants; taxpayers who receive gifts from their masters; captains who do not command; hereditary status that are won or lost by force of character or skills; female warriors; male singers and a social stratification seemingly analogous to that of feudal Europe, but in which even slaves could rise to the rank of nobleman or captain. Starting from this panorama constructed by the specialized literature, lightened by the current reflections of Americanist ethnology, the dissertation exams the data collected by the colonial documentation and the current ethnographies in order to analyze (and to question) the construction of an epistemic regime that reads the relations eyiguayegui/kadiwéu as based on a hierarchy system and on a separation between "domestic" and "political" domains. A close examination of these data has led to the questioning of various terms used over the centuries in the descriptions of the eyiguayegui/kadiwéu political relations, such as "slavery", "labor", "servitude", "symbiosis", "ownership" "social stratification" and the idea of "hierarchy" itself. This questioning has led, finally, to the reflection about the construction of the eyiguayegui bodies and, consequently, of what I denominate distinctions or differentiations between eyiguayegui people.
\end{abstract}

\title{
Key-words
}

Amerindian ethnology; Gran Chaco; Eyiguayegui, Kadiwéu; Hierarchy. 


\section{Lista de Mapas}

Mapa 1 - Localização aproximada dos grupos chaquenhos na época da chegada dos europeus 21

Mapa 2 - Localização aproximada das habitações chaquenhas no fim do século XIX 60 Mapa 3 - Mapa chaquenho da primeira metade do XX 64

\section{Lista de figuras}

Figura 1 - Couro de cervo ornamentado 32

Figura 2 - Nigaana-ake na festa da moça 119

Figura 3 - Pintura corporal feminina 123

Figura 4 - Pintura facial feminina 124

Figura 5 - Pintura facial de uma "escrava" chamacoco 124

Figura 6 - Pintura facial feminina 129

Figura 7 - Jhivajhâá 165

Figura 8 - Chefe dos Guaicurús partindo para comerciar com os brancos 186

Figura 9 - Tribu guaicurú procurando novas pastagens 186

Figura 10 - Carga de cavalaria guaicurú 187 


\section{Abertura 13}

\section{Capítulo 1. Assimetrias entrelaçadas 19}

1.1 Guerra de nomes: a dança chaquenha dos etnônimos 19

\subsection{Eyiguayegui 28}

1.2.1 Toldos, tolderias, parcialidades, nações: os contornos sociais eyiguayegui 28

1.2.2 Niniotageleudi, niniotagilionigi, uneleiguá, nibotagi, niyolola: distinções eyiguayegui 33

\subsection{0 "complexo hierárquico" Eyiguayegui - Guaná 36}

1.3.1 Ideários nacionalistas, sociedades e poder: a definição dos contornos eyiguayegui e guaná 36

1.3.2 Colonialismo Guaná 42

1.3.3 Assimetrias entrelaçadas 46

1.3.4 Simbiose 52

\subsection{Novas alianças, novas guerras 58}

\section{Capítulo 2. Elementos de diferenciação eyiguayegui 66}

\subsection{Elementos de diferenciação eyiguayegui 71}

2.1.1 Estatutos "vocacionais" 71

2.1.2 Escravidão como essência feminina 83

\subsection{Sobre o trabalho: o que se fazia nas tolderias 87}

2.2.1 Doméstico e público; suplício e prazer 89

2.2.2 "Eterno domingo"? 92

2.2.3 Da economia contra o trabalho 96

2.3 Sobre a servidão: como as tarefas eram feitas 101

2.4. Nobreza eyiguayegui 108

\section{Capítulo 3. 0 que pode o corpo eyiguayegui 118}

\subsection{Corpos nobres 128}

3.1.1 Expedições guerreiras 132

3.1.2 Corpos guerreiros 137

\subsection{Fome de crianças 139}

3.2.1 Criação e cativação 139

3.2.2 Caduveização 147

3.2.3 'Virar' outro 152

\subsection{Arte, Guerra e Bebedeira 162}

3.3.1 As mulheres e a guerra 162

3.3.2 As "velhas" e as borracheiras 168

3.3.3 Os homens e a arte 176

\subsection{Avós ou proprietários 181}

Cama de palha e pele de onça: algumas considerações finais $\mathbf{1 8 6}$

Nota metodológica 195

Fontes e referências bibliográficas 200

Anexos 210 


\section{Abertura}

[...] os mbayá têm sempre uma multidão de guanás que os servem como escravos voluntária e gratuitamente, que cultivam a terra para eles e lhes prestam outros serviços. Além destes escravos ou domésticos os mbayás encontram outros muitos nas crianças e mulheres que tomam na guerra e que não são somente índios, mas também espanhóis, de maneira que o mbayá mais pobre tem três ou quatro escravos. Estes vão pegar lenha, cozinham, levantam as tendas ou cabanas, cuidam da alimentação dos cavalos e de prepará-los para a montaria, e também cultivam as terras, o que é bem pouca coisa. Os mbayás não se reservam mais do que a caça, a pesca e a guerra; de maneira que me aconteceu de presentear um mbayá que não quis receber o regalo, ordenando a um de seus escravos recebê-lo: tão vãos e preguiçosos são (Azara 1809:63, tradução minha).

Ao mesmo tempo em que eram reconhecidos como os "índios cavaleiros", opositores ferozes da colonização espanhola e portuguesa nas regiões do $\mathrm{Chaco}^{1}$ e de Cuiabá, os índios Eyiguayegui - referidos por Azara como "mbayá” e conhecidos atualmente como Kadiwéu ou Caduveo - eram também recorrentemente representados nas fontes históricas como "vãos e preguiçosos", inimigos “da agricultura e do trabalho"2. De forma curiosa, a imagem de incansáveis guerreiros convivia com a de nobres fajutos e entregues ao ócio. Segundo os documentos, eles podiam passar dias inteiros sem comer, se isso os pusesse a salvo da vergonha que sentiriam ao cultivar a terra. De acordo com Almeida Serra (1849:204-5), comandante da Coroa Portuguesa, a "altivez e negação ao trabalho" dos capitães eyiguayegui os teria feito "desprezar as fadigas da agricultura" e negar qualquer tipo de atividade que pudesse colocar em risco sua nobreza. Sua solução para esse impasse parecia ser simples: saqueavam dos outros, povos agricultores, o sustento de que precisavam para se manterem vivos. Os primeiros relatos escritos dentro do Forte Assunção narram os diversos ataques empreendidos pelos Eyiguayegui às roças guarani, além das trocas amigáveis que aconteciam entre esses povos. Em todas essas descrições, os "índios cavaleiros" saíam carregados de provisões: milhos, batatas, feijões, abóboras...

Já no final do século XIX, quando os portugueses tentavam aproximar-se dos índios e valer-se de sua mão de obra, uma oferta foi apresentada aos Eyiguayegui: poderiam eles "plantar milho, feijão e criarem porcos" para os militares residentes no Forte Coimbra, sendo-lhes garantido como retribuição o pagamento em forma de "ferramentas, panos brancos, rapaduras, aguardente” etc. Depois de discutir longamente a proposta com o conselho de chefes, o capitão dos Eyiguayegui veio dizer aos portugueses que "tudo estava

\footnotetext{
${ }^{1}$ A área correspondente ao Gran Chaco, bem como as populações presentes na região, serão apresentadas no capítulo 1.

2 Almeida Serra (1850: 370).
} 
muito bem e que elles assim o queriam", completando logo: quantos "escravos" haviam de mandar para fazer aquelas roças? Porque, segundo afirmava, eles não eram cativos. Da mesma forma agiram quando lhes trouxeram madeiras para a construção de novas cabanas: disseram "que as madeiras para elles eram muito duras, e molestavam os hombros, que todos as queriam, mas que lh'as fossem fazer os portugueses" ${ }^{3}$. Cultivar a terra e carregar madeiras pesadas, pelo que se depreende das descrições, não era tarefa para boa parte dos Eyiguayegui. Aliás, o "desprezo" desses índios pela agricultura foi um dos principais motivos alegados para o fracasso das sucessivas tentativas de aldeamento empreendidas pelos jesuítas no século XVIII: os missionários não tinham o que comer porque os índios se recusavam a trabalhar nas roças ${ }^{4}$. De acordo com eles, essa era uma tarefa para seus servos e escravos e - por que não? - para os próprios missionários.

Como conjugar o gênio marcial e aristocrático eyiguayegui à "preguiça" desmoralizante que muitas vezes lhes era atribuída? De que maneira os autores das narrativas coloniais conectavam essas características, antagônicas à primeira vista? $\mathrm{O}$ presente trabalho se debruça sobre questões como essas, procurando interpretar, à luz da contribuição de etnografias relativamente recentes sobre os Kadiwéu ${ }^{5}$, as informações sobre os "índios cavaleiros" trazidas pelas fontes históricas. De saída, é necessário atentar para o fato de que as fontes analisadas nesta dissertação não configuram a totalidade da documentação colonial sobre os Eyiguayegui, e não foi minha intenção explorar esse universo de relatórios, cartas e livros do período que vai do século XVI ao XX. Como a principal intenção dessa pesquisa foi a de dialogar com as obras que fundamentam as análises da política eyiguayegui e kadiwéu, acabei por focar nos documentos geralmente citados como base para a caracterização desses povos como "hierárquicos" e na apreensão das diferenças que os compõem ${ }^{6}$.

A leitura paralela dos documentos históricos e da produção antropológica posterior nos faz perceber que, em grande parte dos antigos relatos, a nobreza e a "preguiça" são tomadas como consequência uma da outra, sendo a "indolência” dos Eyiguayegui uma das facetas (e indícios evidentes) de seu caráter qualificado como aristocrático. Como se verá a seguir, toda a construção da ideia de aristocracia eyiguayegui pela documentação colonial

\footnotetext{
${ }^{3}$ Almeida Serra (1850: 349).

${ }^{4}$ Susnik (1972:79); Herberts (2011:22).

${ }_{5}^{5}$ Ainda que os índios denominados pela literatura contemporânea como "Kadiwéu" se reconheçam também como eyiuayegui, optei aqui por me referir a eles por aquele primeiro nome, de modo a dialogar com as etnografias atuais. A escolha do etnônimo "kadiwéu" em detrimento a eyiuayegui não é discutida nos trabalhos aqui analisados e é um dos temas que merece maior atenção por parte dos etnólogos americanistas.

${ }_{6}$ Realizo a apresentação das obras analisadas no Capítulo I. Além disso, apresento uma discussão mais aprofundada sobre a metodologia da leitura de fontes históricas na Nota Metodológica que, para aqueles que se interessarem, pode ser lida como uma continuidade da Abertura.
} 
tem como base o fato de tais "senhores" não trabalharem. A noção de "trabalho" mobilizada nas fontes, por sua vez, parece estar ligada a atividades "domésticas" e agrícolas, aquelas evitadas pelos "capitães, que se reservavam, como já escrevia Azara, apenas à "caça, a pesca e a guerra". Veremos que o "horror" dos Eyiguayegui pelo "trabalho", que consideravam "próprio de escravos", era diretamente relacionado pelos autores coloniais à sua "innata soberba"7.

O saque, como mencionado, era interpretado como uma das soluções encontradas pelos chamados capitães eyiguayegui para ter acesso a produtos agrícolas sem que precisassem lavrar a terra. Além dessa, parecia haver também uma (ou duas) outra(s) maneira(s) de se livrar desse tipo de trabalho: aquilo que grande parte dos documentos históricos denomina, indiscriminadamente, como escravidão, e que a literatura antropológica convencionou dividir em servidão e escravidão ${ }^{8}$.

De maneira geral, essas duas categorias remetem às relações supostamente hierárquicas entre os grupos eyiguayegui e índios ou não-índios de outras populações. As descrições são bem claras em afirmar que qualquer contato dos índios cavaleiros com outros grupos era permeado por um sentimento de "superioridade", "arrogância” e "soberba" de sua parte: eles se distinguiam como a "primeira e dominante nação de índios, contando todas as outras por suas cativeiras”, não se julgando inferiores sequer aos espanhóis e portugueses ${ }^{9}$, fato que evidentemente alarmava os autores das narrativas e mesmo antropólogos. Pierre Clastres (2004: 272), aliás, afirmava que os Eyiguayegui "pouco se perturbavam com sutilezas nas distinções sociais”, considerando o resto das nações chaquenhas suas escravas.

"Escravidão" e "servidão" aparecem tanto em fontes históricas quanto em análises antropológicas como consequências lógicas dessa maneira eyiguayegui de se relacionar com o outro: segundo essa linha de raciocínio, sua "nação" se considerava nobre, logo seria superior às outras, subjugando-as e transformando-as em populações servis. Essa noção de servidão, por sua vez, é mobilizada na literatura especializada de duas maneiras. Na primeira, denomina uma relação mais específica - aquela entre os "senhores" eyiguayegui e seus "servos" guaná - fundamentada no suposto pagamento anual de tributos agrícolas. Na segunda, refere-se mais amplamente à situação de sujeição e dependência a que estariam submetidos tanto "servos" quanto "escravos" (os cativos de guerra). O que está na base dessa noção de "servidão", porém, não é explicitado pelas fontes e nem parece ser unanimidade: os

\footnotetext{
7 Almeida Serra (1850: 348).

8 Já nos documentos históricos há a diferenciação entre dois tipos de "sujeição", mas essa separação só é claramente efetuada depois da análise dessas fontes por antropólogos como Alfred Métraux (1946), Branislava Susnik (1971; 1972) e Herbert Baldus (1975).

9 Almeida Serra 1849: 204.
} 
próprios autores relativizavam essa noção, descrevendo-as por vezes como “doce”. A qualificação das relações a que chamaríamos políticas entre os Eyiguayegui, portanto, parece ser resultado da junção entre o conceito europeu de servidão e a "doçura" dos senhores chaquenhos.

Nesse sentido, interessa-me aqui elucidar aquilo que era chamado pelas fontes de "una esclavitud muy dulce" ${ }^{10}$. Parto do pressuposto de que essas descrições tratam "sem dúvida de alguma coisa bem real, mesmo que se lhe queira dar outro nome; se não um modo de ser, era um modo de aparecer" 11 dos Eyiguayegui aos olhos dos autores das fontes. Esse "modo de aparecer" eyiguayegui, por sua vez, era marcado por relações desconhecidas pelos observadores e colocava problemas às suas próprias classificações. Na contramão do que pensavam os autores dos relatos históricos, portanto, proponho questionar a suposição de que essas relações são bem entendidas por meio do conceito de servidão. Sugiro que, mesmo quando qualificada como "doce", a noção traz consigo pressupostos quanto ao que sejam estratificações sociais, trabalho, propriedade e mesmo humanidade.

Os capítulos que se seguem efetuam um esforço de distanciamento e questionamento de muitas das categorias que vicejam na literatura sobre os antigos Eyiguayegui e atuais Kadiwéu. Um questionamento inicial - o que se convencionou chamar de hierarquia eyiguayegui? - acabou por abrir um panorama muito mais amplo em que termos como “escravidão", "servidão", "simbiose”, "estratificação social” e a própria ideia de "hierarquia” passaram por reflexões necessárias para o entendimento do que agora denomino distinções ou diferenciações entre as pessoas eyiguayegui. Ainda que eu não tenha a pretensão de afirmar, nas linhas que se seguem, o que "realmente" acontecia nas tolderias eyiguayegui descritas pelas fontes, meu esforço foi o de seguir as narrativas nelas presentes de modo a esmiuçar a construção de um regime epistêmico que lê as relações eyiguayegui/kadiwéu como baseadas em uma hierarquia e em uma separação entre os domínios “doméstico” e "político”.

Longe de pretender ler a documentação colonial e as análises antropológicas por meio de um conceito - o de "hierarquia" -, portanto, intento aqui exatamente o contrário: liberar as descrições dos capitães eyiguayegui e seus cativos dos "constrangimentos ou limites" que elas mesmas se impõem "ao reivindicar um confinamento cujo traçado se decidiu de antemão [...], como condição de sua própria operação, e, simultaneamente, de levantar os temas relacionados ao seu confinamento" ${ }^{12}$, fazendo do próprio conceito matéria mesma da investigação e objeto de questionamento. É importante notar que o presente trabalho não

\footnotetext{
10 Azara (1809: 56).

${ }^{11}$ A citação é de Eduardo Viveiros de Castro (2002: 190), em seu ensaio sobre a suposta "inconstância” dos Tupinambá da costa.

${ }^{12}$ Drago (2012:24).
} 
dialoga diretamente com a noção antropológica de hierarquia, desenvolvida principalmente por Louis Dumont em sua obra Homo Hierarchicus (2008). Ainda que os paralelos entre o material chaquenho e alguns dos temas trazidos pelo autor francês - como os diferentes valores atribuídos às diversas atividades; o modelo do "englobamento do contrário", basilar para a construção do dravidianato amazônico; e a crítica à associação direta entre hierarquia e poder - sejam diversos e provavelmente muito produtivos, optei por dissecar uma "hierarquia" específica, aquela construída na literatura sobre o Chaco. Nesse sentido, pretendo apresentar algumas armadilhas colocadas pelo vocabulário das fontes e análises antropológicas e, ao mesmo tempo, apontar possíveis saídas e alternativas.

No capítulo I, intitulado “Assimetrias entrelaçadas”, me aproveito de um breve histórico dos índios inicialmente denominados Guaicurú e posteriormente Eyiguayegui para realizar também a exposição dos autores, documentos e etnografias aqui analisados. A apresentação dos dados relativos aos povos chaquenhos abriu também a possibilidade de discutir as dificuldades de efetuar um mapeamento preciso fundamentado apenas nas fontes históricas devido àquilo que denomino a "dança chaquenha dos etnônimos", ou seja, a grande variabilidade dos nomes empregados nas descrições europeias sobre o Chaco e a aparente facilidade com a qual esses etnônimos (muitas vezes cristalizados pela literatura) surgem e/ou desaparecem. Discuto, ainda nesse capítulo, a suposta (e também famosa) "relação de servidão" entre os índios eyiguayegui e guaná, bem como a noção de "simbiose" muitas vezes utilizada nas descrições desse chamado "complexo hierárquico”.

Se o primeiro capítulo se dedica àquilo que chamei de "servidão mais específica” entre os "senhores" eyiguayegui e os "servos" guaná, o segundo (denominado "Elementos de diferenciação eyiguayegui”) se concentra naquela servidão "mais ampla” e na situação de inferioridade a que estariam sujeitos, segundo as fontes históricas, tanto "servos" e "escravos" quanto mulheres. A reflexão acerca da relação entre as noções de servidão e trabalho ganha corpo neste segundo capítulo, que também apresenta as diferentes atribuições como indícios das distinções eyiguayegui, além de abordar a constituição de sua "nobreza”.

Por fim, o capítulo 3, "O que pode o corpo eyiguayegui”, tem como ponto central a relação entre a construção do corpo e as atribuições e estatutos apresentados no segundo capítulo. Demonstro que a instabilidade dos corpos - constituinte dos nobres guerreiros, dos cativos de guerra, dos homens e das mulheres - era o que fazia com que os autores das fontes coloniais ficassem inseguros quanto às formas de qualificação de suas relações, denominandoas como "doces". Em todos esses casos, o destino de "virar" outro está colocado e é buscado por meio das expedições guerreiras e das bebedeiras. Neste capítulo analiso também os diversos problemas colocados pelas fontes à oposição muitas vezes efetuada pela literatura 
especializada entre "senhores da guerra" e "senhoras da arte" e à noção de "propriedade", ainda hoje entendida como fundamental na relação entre senhores e cativos. 


\title{
Capítulo 1. Assimetrias entrelaçadas
}

\author{
Sordos \\ Yucatán, unos cuantos nativos les salieron al encuentro. \\ castellana: \\ - ¿Dónde estamos? ¿Cómo se llama este lugar? \\ $\Upsilon$ los nativos dijeron, en lengua maya yucateca: \\ - Tectetán, tectetán. \\ Los españoles entendieron: \\ - Yucatán, Tucatán. \\ $\Upsilon$ desde entonces, asi se llama esta península. \\ Pero en su lengua, los nativos habian dicho: \\ - No te entiendo, no te entiendo.
}

Cuando los conquistadores españoles pisaram por vez primer a las arenas de

Según contó Toribio de Benavente, los españoles les preguntaron, en lengua

"El cazador de historias", Eduardo Galeano.

\subsection{Guerra de nomes: a dança chaquenha dos etnônimos}

A costa do Rio Paraguai, frequentemente inundada pelas águas correntes, cercada por "magníficos arvoredos" e envolvida por calor abrasante e "chuvas torrenciais" ${ }^{1}$ na maior parte do ano foi o cenário do encontro dos Eyiguayegui com os europeus. Na primeira metade do século XVI, suas habitações situavam-se às margens ocidentais do rio, na região conhecida pelos espanhóis como Gran Chaco (do quíchua chacu, "território de caça”) e localizada entre os atuais territórios do Brasil, Paraguai, Argentina e Bolíviaª . Eles estavam assentados no Chaco boreal, não muito abaixo do atual município de Corumbá, quando foram surpreendidos por uma expedição de índios guarani que vinha do litoral catarinense e era acompanhada pelo explorador português Aleixo García? . Com eles, os “índios Mbayáes" - como os Eyiguayegui eram

\footnotetext{
${ }^{1}$ As citações são de Taunay (1874:4) e Sánchez-Labrador ([1770-1776], v. I:150), respectivamente. Muitas das fontes analisadas na pesquisa contêm belas descrições da região habitada pelos Eyiguayegui. ${ }^{2} \mathrm{O}$ Chaco tem como limites naturais os rios Paraná e Paraguai a leste, as cordilheiras andinas a oeste, o planalto mato-grossense a norte e a bacia do rio Salado ao sul (Tola 2013:12). Os estudos do Chaco convencionaram dividi-lo, de acordo com seus níveis pluviométricos, em três sub-regiões: Chaco úmido, em sua porção oriental, Chaco central e Chaco seco, a leste. Pode-se também subdivir a região chaquenha em Chaco boreal, ao norte do rio Pilcomayo, Chaco central, entre os rios Pilcomayo e Bermejo e o Chaco austral, a sul do Bermejo (Tola 2013:12). As línguas faladas pelos povos chaquenhos são: Guaicurú (Toba/Qom, Pilagá, Toba-Pilagá, Mocoví e Mbayá/Kadiwéu), Mataco-Mataguaya (mataco-wichí, chulupi/nivaklé, chorote e maká); Tupi-Guarani (chiriguano/avá, taiete, chané, isoseño/guarani, guarani ocidental); Enlhet-enenlhet (enxet/lengua, enlhet, angaité, sanapaná, guaná, e toba-maskoy/enenlhet) e Lule-Vilela (vilela/chulupí) (Tola 2013:13).

${ }^{3}$ A data dessa visita não é certa, mas sabe-se que a expedição aconteceu entre os anos de 1521 e 1526 (Métraux 1946:199).
} 
denominados pelos Guarani, em referência às esteiras utilizadas por aqueles na construção de suas casas - teriam trocado algumas placas de prata por produtos manufaturados europeus. A expedição dos índios guarani e de García seguiu, então, na direção noroeste, onde se encontravam as aldeias Guaná, vizinhas às dos Mbayá (Herberts 1998:66).

Os exultantes diários de García, em conjunto com as barras de ouro e prata por ele enviadas, chegaram à Europa expondo a riqueza da região andina e descrevendo os caminhos chaquenhos que levavam à terra do já lendário império Inca (ver Bueno 1987). Ocasionou-se então uma corrida pelo ouro: a Coroa Espanhola não poupou esforços para a construção de fortes no Chaco e sua consequente colonização. Em 1536, os espanhóis fundaram o Forte Assunção, que passou a servir de base para a exploração da região, considerada no momento uma "porta de entrada para as fabulosas terras do oeste" ${ }^{5}$. Até então, o Chaco em si carecia de importância aos olhos dos exploradores.

Um ano depois, em fevereiro de 1537, chegou às terras eyiguayegui o explorador espanhol Juan de Ayolas, tendo como destino o Forte Assunção. Para chegar até os Eyiguayegui, Ayolas atravessou o rio Paraguai e, já nas margens ocidentais, caminhou na direção oeste, passando primeiramente pelos Payaguá6. Também Ayolas deixou as terras dos "Mbayá” para conhecer o território Guaná, localizado Chaco adentro. Na mesma época, entre 1540 e 1550 , aqueles índios receberam ainda a visita do alemão Ulrich Schmidel $([1602])^{7}$, também enviado ao Forte Assunção pela Coroa Espanhola. Descrito por seus pares como um homem de espírito curioso e aventureiro, o soldado havia chegado muito jovem à América do Sul, onde se quedou por aproximadamente 20 anos, incentivado, assim como muitos outros exploradores, pela busca da Serra da Prata. Em 1547, Schmidel descreveu os "Mbayá" em uma localização parecida com aquela informada por Ayolas, próxima às margens ocidentais do Rio Paraguai e vizinha dos aldeamentos guaná.

\footnotetext{
4 Também encontrado como Mbayá, Mbaia, Maieaiss, Mayeaiess, Maipais, Albaias. A acepção da palavra em guarani é informada pelo missionário Sánchez-Labrador ([1770-1776], v. I:268).

${ }^{5}$ Métraux (1946:199, tradução minha).

${ }_{6}^{6}$ Também reconhecidos nas fontes como Agaces.

7 Considerando a data da primeira publicação das obras aqui analisadas uma informação de grande importância para o desenvolvimento do argumento, optei por informar, nas citações, apenas esta data, entre colchetes. A edição consultada e citada é informada nas Fontes e Referências Bibliográficas. No caso dos relatórios militares publicados na Revista do Instituto Histórico e Geográfico Brasileiro, cita-se apenas a data de publicação do volume da revista.
} 
Mapa 1 - Localização aproximada dos grupos chaquenhos na época da chegada dos europeus

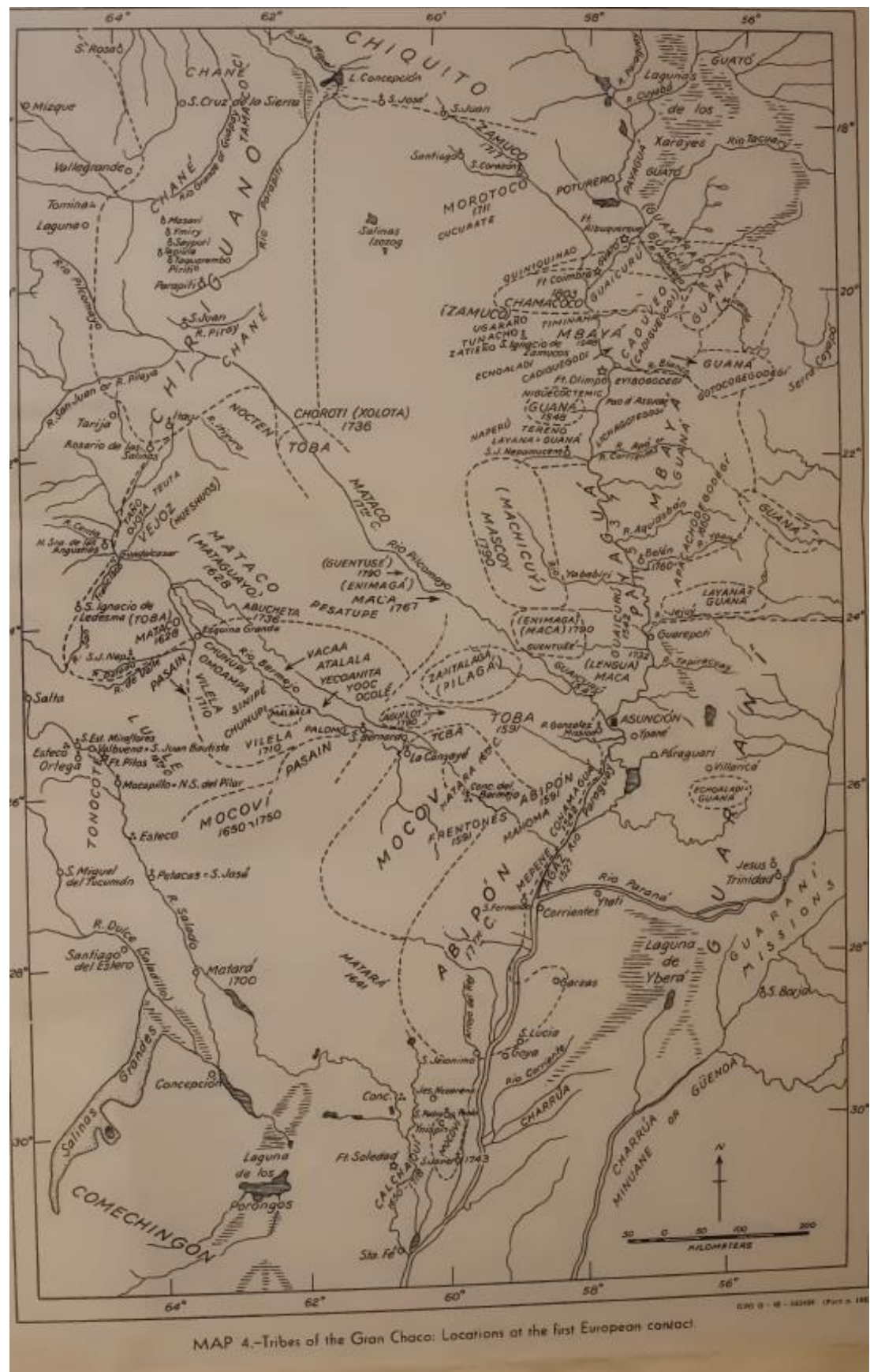

Fonte: Métraux (1946: 198)

Alguns dos grupos mbayá teriam se instalado também mais a noroeste, próximos à primeira cidade de Santa Cruz, hoje San Jose de Chiquitos, de acordo com descrições de um certo "povo de mayaes" datadas de 1561 (Richard \& Combès 2015:234). E essa não é a única fonte a apontar sua localização longe do local em que eles foram "originalmente" encontrados. Os documentos estão repletos de descrições que os posicionam em locais diversos, algumas vezes próximos e em outras muito 
distantes entre si. Além de sua localização, as maneiras de denominá-los também são diversas: vimos que García, Ayolas e Schmidel chamam essas populações "Mbayá", adotando o nome pelo qual eram conhecidos pelos Guarani, que os guiavam na maior parte das vezes. Em outras ocasiões, porém, populações que parecem ser as mesmas são denominadas "Guaicurú8" (em língua guarani, "gente malvada e suja"9 ou "sarnentos"10).

Essa variabilidade dos etnônimos se explica por seu caráter contex tual: como os nomes têm origem em relações (como a Guarani-Eyiguayegui), tendem a mudar de descrição para descrição, transformando-se conforme muda o ponto de vista de quem os vê. Os "Guaicurú”, nesse sentido, só eram um grupo homogêneo na visão "dos Guarani”, que uniam os "sarnentos” em uma só categoria. “A oposição”, já afirmavam Perrone-Moisés e Stutzman (2010:418), “é o fato primeiro, grupos há porque se opõem e na medida em que se opõem. Conforme mudam as oposições, mudam os grupos”. Incapazes de descrever o Chaco sem recorrer a identidades substanciais - inexistentes entre os chaquenhos e outras populações americanas -, as fontes ${ }^{11}$ acabam criando a impressão de uma "descontinuidade etnonímica”: em pouco tempo, distintos nomes são utilizados para descrever a mesma área, ou a mesma região é descrita por meio de etnônimos totalmente diferentes, que não levam em consideração nem os diferentes níveis de relações ali implicados, muito menos as formas nativas de conceitualização da sociabilidade (ver Villar \& Córdoba 2010; Wagner 2010). A leitura das informações históricas aqui salientadas, portanto, precisa levar em consideração o fato de que os etnônimos ali presentes designam “[ $[.$.$] una trama variable de categorías que reflejan$ articulaciones, mediaciones y relaciones"12 entre os grupos aos quais os europeus se referiam. A realização de um mapeamento mais preciso das antigas populações chaquenhas, nesse sentido, não está no escopo deste trabalho, que se debruça apenas sobre as descrições europeias dessas populações ${ }^{13}$.

\footnotetext{
8 Também encontrado nas fontes como Guaycurú, Guaikuru, Aicurus, Aycurús, Uaicurús.

${ }^{9}$ Herberts $(2011: 17)$

10 Richard (2011:214).

${ }^{11}$ E não apenas as fontes: Roy Wagner (2010) mostra como a própria antropologia social construiu seu vocabulário analítico por meio da ideia da formação de "grupos", tomando como premissa a participação consciente dos indivíduos a uma entidade maior, a sociedade.

12 Villar \& Córdoba (2010:35).

13 A dissertação de Jaime Siqueira Jr. (1993) e a tese de Mônica Pechincha (1994), por sua vez, trazem diversas narrativas dos próprios Kadiwéu acerca da presença histórica de seus antepassados, os Eyiguayegui, nas terras até hoje habitadas por eles. Estas sim, quando cotejadas às informações trazidas pelos documentos coloniais, podem trazer dados mais confiáveis sobre a antiga ocupação da Reserva Indígena Kadiwéu.
} 
Uma das primeiras menções aos índios denominados Guaicurú, realizada em meados de 1540, é a de Álvar Nuñez Cabeza de Vaca, então recém-nomeado Governador da região do Rio da Prata. Cabeza de Vaca era reconhecido como um grande explorador, homem "intrépido e incomum"14: dada a impossibilidade de se deslocar de Santa Catarina até Assunção de cavalo, Cabeza de Vaca seguiu seu trajeto a pé, utilizando o Peabiru, caminho milenar dos Guarani, que havia trazido também Aleixo García ao território chaquenho. Antes da chegada de Cabeza de Vaca ao Forte Assunção, os militares que o guardavam haviam estreitado relações com grupos de língua guarani, de quem recebiam informações sobre os territórios e povos ainda desconhecidos da bacia do Rio da Prata ${ }^{15}$. Destes índios, Cabeza de Vaca (e todos os exploradores até então referidos) recebia $(\mathrm{m})$ grande parte de suas informações sobre as nações indígenas chaquenhas, inclusive os "Guaicurú".

Importante notar que todos os relatos citados até aqui mostram claramente a localização dos povos Guarani nessa época: as margens ocidentais e orientais chaquenhas, justamente onde os espanhóis estabeleciam seus assentamentos até os fins do século XVI, quando o empreendimento de atravessar o Chaco era ainda incomum. Com vistas a "pacificar" os povos indígenas do interior chaquenho, os espanhóis contaram por muito tempo com o sentimento - anterior à invasão europeia - de inimizade entre seus anfitriões guarani e os grupos do Chaco central. Longe de serem aliciados inocentemente pelos colonizadores, como os documentos sugerem, porém, os Guarani se aproveitavam das trocas com os europeus e de seu aparato bélico para colocar em movimento o ciclo de guerras com os "sarnentos" do interior chaquenho. Como acontecia entre os Tupinambá da $\operatorname{costa}^{16}$, havia ali uma lógica antecedente à chegada dos colonizadores: os povos por vezes referidos como "Guarani” eram inimigos mortais dos povos denominados por eles "Guaicurú".

Aliando-se aos exploradores espanhóis, os Guarani atuavam frequentemente como guias, formando suas opiniões sobre as outras populações habitantes do interior do Chaco, suas oponentes. A influência dos Guarani sobre os recém-chegados era tanta que Branislava Susnik ${ }^{17}$ (1971:9) chega a afirmar que, enquanto estes eram considerados "amigos" pelos espanhóis,

\footnotetext{
${ }^{14}$ Bueno (1987:17-8).

${ }^{15}$ Herberts (2011:20).

16 A respeito dos blocos compostos por europeus e índios, como aquelas que opuseram, em um determinado contexto, grupos tupi da Costa aliados aos franceses de um lado e outros (inimigos daqueles) aos portugueses de outro, ver Perrone-Moisés (2004; 2008) e Perrone-Moisés \& Sztutman (2010).

${ }^{17}$ Antropóloga eslovena que se dedicou, desde a década de 1950 até sua morte, ao trabalho de
} 
este primer status político de amistad se negaba a los chaqueños y a otras tribos en el área de las travesías hacia El Dorado; estas tribus no eran más que 'escraverías', generaciones rebeldes, hostiles y potencialmente traicioneras.

Jogando com as noções dicotômicas europeias - em que aquele que não é "amigo" só pode ser mesmo "escravo" - os Guarani partiam para expedições guerreiras contra os Guaicurú acompanhados de militares espanhóis, atualizando conflitos muito mais antigos que a chegada dos assucenhos ${ }^{18}$. Essas disputas eram permeadas também por outra tendência europeia ao maniqueísmo, que colocava em uma mesma categoria todos os povos de língua guarani, como os Carió e os Chiriguano, distintos entre si na maior parte do tempo, mas aliados quando se tratava de guerrear contra seus inimigos. Mesmo ciente dessa pulverização dos grupos denominados nas fontes “Guarani”, opto por manter esse etnônimo, mobilizado aqui como parte do argumento de que estes nomes nunca são fixos, mas contextuais. Os "Guarani” aparecem neste capítulo, portanto, como um grupo circunstancial de opositores dos "Guaicurú".

Além de informar os estrangeiros sobre a "selvageria" dos povos do interior, os Guarani comunicavam-lhes também sobre a localização desses grupos. Guaicurú e Mbayá - nomes adotados pelos europeus em suas descrições - são "termos guarani utilizados para designar as populações não falantes do guarani situadas depois da fronteira colonial paraguaiense"19. Sendo já em sua origem um vocativo genérico, o termo Guaicurú acabou, enfim, por ser utilizado indistintamente pelos europeus, passando a designar uma família linguística apenas posteriormente. De acordo com Susnik (1971:23), “el apelativo 'Guaycurú' estaba tan arraigado en la consciencia colonial a través de la preocupación por 'el peligro guaycurú', que el mismo apelativo aplicábase a cualquier banda o cualquier tribu atacante e incursionista ecuestre”. $\mathrm{O}$ etnônimo Guaicurú foi estendido, assim, aos povos que habitavam as franjas chaquenhas e apresentavam um comportamento belicoso e "traiçoeiro" ou, nas palavras de Susnik (1971:18), um "etos guerrero"20. Ao sul, os Guaicurú estariam nas proximidades do Forte Assunção e ao norte os Mbayá - tidos como "os Guaicurú do norte” (Susnik 1971:45) - seriam encontrados às margens do Rio Paraguai.

sistematização das informações acerca dos povos chaquenhos. Seus estudos são fundamentais para a literatura especializada na região.

18 Segundo Carvalho (2002:467), “os próprios Guarani exigiam dos espanhóis 'expedições punitivas' [contra os Guaicurú], das quais participavam de bom grado”.

19 Richard (2011:221, tradução minha).

${ }^{20}$ Os espanhóis acabavam por fazer uma contraposição ingênua e simplista em que os "povos Guaicurú” apareciam como guerreiros impiedosos e os Guarani como agricultores amistosos. Veremos que essa antítese construída pelos documentos coloniais encontra diversos paralelos em toda a literatura chaquenha. 
A relação entre os Mbayá e os Guaicurú, porém, não fica muito clara nas fontes e mesmo os antropólogos não chegaram a um consenso. Segundo Herbert Baldus (1975:17), por exemplo, antigamente, sob os nomes de Guaicurú e Mbayá “se compreendia um número de tribos do Chaco e também da parte oriental da bacia do Paraguai, das quais sabemos hoje que têm na sua cultura, ao lado de certas analogias, profundas divergências e pertencem a famílias linguísticas inteiramente diversas". Já Branislava Susnik vê diversos pontos de contato entre as populações Guaicurú do sul e do norte, como seu desdém pela agricultura, gosto pelo rapto aos cativos e presença de "rituais de guerra”. Segundo Susnik (1971:22), "los documentos coloniales" chegam a falar em "confederaciones guaycurúes", que uniam determinados grupos por meio de seu caráter belicoso. O fato é que, mesmo que essas populações tenham se unido eventualmente em contextos conflituosos, elas logo se separavam novamente, não permanecendo unas por muito tempo - mais uma vez, de modo muito parecido com o dos Tupi da costa e dos Iroqueses (Perrone-Moisés 2006; Perrone-Moisés e Sztutman 2010). A história chaquenha, assim como a de diversos contextos etnográficos, revela processos de "fisión y de fusión, de concentraciones y de atomizaciones, de aceleraciones y repliegues, de mutaciones, mediaciones y relaciones" que eram incompreendidos pelos europeus, o que tornava a fixação dos antigos grupos chaquenhos no tempo-espaço uma tarefa complicada ${ }^{21}$. Mais interessante é tentar acompanhar nos documentos coloniais os movimentos indígenas e seus jogos relacionais que fazem nomes e designações dependerem dos contextos, dos interlocutores e das circunstâncias.

Mesmo não sendo possível, por meio da análise das fontes, fazer grandes declarações sobre a localização exata dos grupos identificados pelos diferentes etnônimos ao longo dos séculos, pode-se afirmar que os nomes por meio dos quais os Eyiguayegui foram geralmente conhecidos se referiam - pelo menos na visão dos europeus - à sua índole guerreira. Os relatos do final do século XVI e início do XVII ${ }^{22}$ ressaltam o domínio que esses povos pareciam ter sobre o território chaquenho, o que fez com que o apelativo "Guaicurú" se convertesse " $[\ldots]$ en un símbolo del peligro potencial para la economía y demografía hispano-colonial” (Susnik 1971:23). O conjunto dos relatos do século XVII, mesmo não sendo muito grande, conseguiu formar uma imagem grandiloquente dos Guaicurú, que estariam vivendo nessa época

\footnotetext{
${ }^{21}$ Sobre a dificuldade do mapeamento de etnônimos por meio de fontes históricas, ver Villar \& Córdoba 2010:42; ver também Tola 2010.

${ }^{22}$ Período em que os espanhóis chegaram finalmente à Serra da Prata e perceberam que as tropas de Pizarro já a haviam conquistado, inutilizando todas as suas tentativas de colonização do Peru via Chaco.
} 
seu "apogeu étnico" (Herberts 2011:36). Grande parte desse clímax guerreiro reconhecido pelas fontes teria origem na já famosa "adoção do cavalo" pelos índios, que teria ocasionado "uma revolução econômica, social e política" naquelas "sociedades guerreiras e sem gosto pela agricultura” (Métraux 1946:202). Sem dúvida, os cavalos adotados pelos Guaicurú os ajudaram nos assaltos aos fortes espanhóis, permitindolhes vencer diversas batalhas contra os estrangeiros e voltar para suas habitações sem nenhuma represália. Esses ataques, por sua vez, faziam com que estes povos roubassem cada vez mais cavalos, ficando portanto mais poderosos e passando a impressão de serem onipresentes, sendo encontrados por todo o território chaquenho (Susnik 1972:63). Suas expedições guerreiras em busca de cativos passaram a ser cada vez mais frequentes e seus assaltos às cidades dos colonizadores eram fatais: os ataques à vila de Corrientes, na segunda metade do XVII, por exemplo, destruíram-na praticamente em sua totalidade (Herberts 2011:24). As sucessivas tentativas de sedentarização empreendidas pelos jesuítas fracassavam por conta do que as fontes descreviam como um “desprezo" daqueles índios pela agricultura (a que se dedica o capítulo 2) e por seus ataques frequentes a outras populações (Herberts 2011:22). Quando aceitavam o estabelecimento de missões, concordando em "servir aos espanhóis" (Cabeza de Vaca [1555]:163), os povos denominados Guaicurú tinham muitas vezes como intenção se aproximar das cidades para então atacá-las, costume que fez com que o Forte Assunção passasse por um período de prostração econômica até meados do século XVIII ${ }^{23}$.

Ainda assim, a pressão da frente colonizadora espanhola ao longo do século XVII fez com que os "Guaicurú do sul” se deslocassem gradualmente para o norte, em um movimento que Susnik (1971:46) descreve como uma "agregação" destes aos Mbayá setentrionais. Embora essa "agregação" seja discutível, é perceptível que as fontes, já ao final deste século, passaram a registrar os Mbayá-Guaicurú principalmente no Chaco boreal. É nessa época que os documentos relatam a travessia de algumas dessas populações para a margem oriental do rio Paraguai (no atual Mato Grosso do Sul) e o domínio inconteste dos Guaicurú sobre suas duas margens. Segundo Susnik (1972:61), a travessia do rio teria sido motivada pela busca da palma eyiguá, que oferecia fibras têxteis, frutos comestíveis e a farinha que era base de sua alimentação, da bebida fermentada e da tintura branca com a qual faziam as pinturas corporais. O nome dessa planta encontra-se na origem do etnônimo Eyiguayegui -

${ }^{23}$ Herberts (2011:24); Susnik (1972:60); Cabeza de Vaca ([1555]:163); Almeida Serra (1850:369); Rodrigues do Prado (1795:48). 
"oriundos da terra em que abunda o eyiguá, segundo Sánchez-Labrador ([1770-1776], v. II: 5$)^{24}$.

O jesuíta José Sánchez-Labrador, que fundou entre os Mbayá do norte a missão Nossa Senhora de Belém em agosto de 1760, é o autor do relato mais minucioso - e considerado um dos mais preciosos - desse período. A missão contava com cerca de 1.300 pessoas e tentou reunir em um mesmo lugar os Apacachodegodegis e Lichagodegis, grupos distintos e por vezes rivais. O empreendimento de SánchezLabrador foi uma das últimas tentativas jesuíticas de pacificar os grupos chaquenhos "rebeldes" que as tropas espanholas não haviam conseguido subjugar (Métraux 1963:201). Suas tentativas, porém, não obtiveram sucesso: "contra a tarefa da evangelização" se ergueu, "insuperável, o obstáculo da diabólica paixão guerreira dos índios"25; os padres não conseguiram obrigar nem convencer os Mbayá a trabalhar nas roças; os unigene (xamãs mbayá-guaicurú) e as "velhas” não pararam de realizar suas curas; os conflitos internos e constantes clivagens grupais não permitiam que o grupo de pessoas estabelecidas nas missões fosse permanente e, pior de tudo, os índios sentiam-se "visitantes" nas missões, encontrando-se no direito de exigir dos espanhóis "carne, sal e tabaco" e de partir logo depois de terem seus desejos satisfeitos (Susnik 1972: 79).

Depois que os jesuítas foram expulsos pela Coroa Espanhola e substituídos pelos franciscanos, o Gran Chaco passou a ser conhecido na Europa, o que fez com que os diários dos missionários fossem publicados e sirvam até hoje como base dos estudos historiográficos, arqueológicos e antropológicos sobre a região²6. O século XVIII é reconhecido, portanto, como o século de ouro da documentação histórica sobre ela (Métraux 1946:206). Foi esse boom de produções hispânicas sobre o Chaco nesse período que trouxe à luz descrições mais detalhadas sobre o cotidiano daqueles povos, cunhou certos termos característicos da literatura da região até os dias de hoje - como tolderia, parcialidade e capitania - e tornou conhecida a "hierarquia” 27 dos Mbayá-

24 A palma eyiguá tem uma importância central na alimentação em épocas de resguardo e na pintura corporal, sendo portanto um dos principais elementos na construção das potencialidades do corpo eyiguayegui.

${ }_{25}$ Clastres (2004: 262).

26 Segundo P. Clastres (2004: 262-3), grande parte dos nossos conhecimentos sobre as antigas populações chaquenhas se devem às "soberbas descrições" dos missionários, "enriquecidas por anos de contato com os índios, pelo conhecimento de suas línguas, por uma real simpatia dos jesuítas em relação aos ferozes guerreiros. É assim que desde agora está associado à tribo dos Abipones o nome de Marin Dobrizhoffer, aos Mocovi o de Florian Paucke, aos famosos Guaykuru-Mbayá o de José Sanchez Labrador, sem esquecer a obra de Pedro Lozano, historiador da Companhia de Jesus, dedicou especialmente às sociedades do Chaco".

27 O termo é utilizado por Sánchez-Labrador ([1770-1776], v. I: 27) em suas descrições sobre a organização social eyiguayegui. Daqui em diante, utilizarei o termo todas as vezes em que estiver me 
Guaicurú. Se antes os escritos sobre os índios chaquenhos baseavam-se principalmente em impressões resultantes das expedições exploratórias ${ }^{28}$, no século XVIII, com o estabelecimento de mais fortes e missões na região, os europeus puderam entrar em contato com os antes genéricos "Mbayá-Guaicurú” e diferenciá-los melhor. Não por acaso a autodesignação dos até então conhecidos "Mbayá do norte", Eyiguayegui, aparece na literatura justamente neste período mais monográfico da história chaquenha. Conforme mudavam o caráter e a riqueza dos escritos sobre esses povos mudavam também seus etnônimos. Os vocativos "Guaicurú”, "Mbayá”, "MbayáGuaicurú" e "Eyiguayegui” aqui utilizados, portanto, não devem ser medidos por uma régua de veracidade, como se uns fossem mais verdadeiros do que outros. Devem, sim, ser entendidos como resultantes das relações em jogo entre os grupos envolvidos, e daquelas entre os grupos e os autores dos relatos em que são nomeados ${ }^{29}$. Nesse sentido, opto por manter o etnônimo Eyiguayegui de modo a deixar clara a intenção de analisar os relatos sobre aqueles de que os atuais Kadiwéu (hoje habitantes da Reserva Indígena Kadiwéu, no Mato Grosso do Sul) se consideram descendentes - os povos oriundos da terra em que abunda a palma eyiguá.

\subsection{Eyiguayegui}

\subsubsection{Toldos, tolderias, parcialidades, nações: os contornos sociais eyiguayegui}

É a partir do século XVIII que as habitações eyiguayegui nos são apresentadas. De acordo com os relatos dessa época, cada capitão eyiguayegui vivia com seus parentes e cativa/os em seu toldo, habitação típica chaquenha, reunindo em torno de si outros toldos que formavam, em conjunto, uma tolderia ${ }^{30}$. Esse vocábulo castelhano era correntemente utilizado pelos jesuítas e é usado até hoje na denominação do que, em outros contextos etnográficos, seria chamado de "aldeia" ou "grupo local". O próprio Guido Boggiani ([1895]:85) - célebre paisagista e comerciante italiano que viveu entre os então Kadiwéu em 1892 - afirma que o termo tolderia “[p]oder-se-ia

referindo à suposição (tanto dos autores das fontes quanto dos antropólogos) de que as relações eyiguayegui se baseiam em uma sujeição, ou inferiorização de uns pelos outros. Outras expressões, como “estratificação social”, serão mantidas acompanhando seu uso pelos autores das fontes em questão.

28 Nas palavras de Richard e Combès (2015: 231), até a metade do século XVIII os Guaicurú “[a]pareciam nas fronteiras do espaço colonial para assaltar povoados e roubar gados antes de se perderem novamente na imensidão sem que ninguém soubesse exatamente onde se localizavam seus acampamentos, nem como se pareciam”.

29 Sobre a ruptura na carta etnográfica do Chaco, ver Richard (2008; 2011). O autor relaciona o aparecimento dos novos etnônimos chaquenhos à escrita monográfica na região, aparentemente simultâneos.

30 Sánchez-Labrador ([1770-1776], v. I:273). 
traduzir por aldeia; mas assim não se exprimiria tão bem o verdadeiro sentido daquele vocábulo”, julgando "conveniente adotá-lo de preferência a qualquer outro".

As tolderias eram formadas por uma fila de toldos, unidos uns aos outros de maneira a formar uma meia-lua ${ }^{31}$. Em algumas descrições, afirma-se que o capitão da tolderia e os seus viviam no toldo central, que em alguns casos era mais alto e, em outros, igual aos demais, existindo também relatos em que sua habitação era separada das outras. Os toldos eram construídos com troncos de madeira que os sustentavam, cobertos por esteiras trançadas com a palha eyiguá, e seu interior era ocupado pelos jiraus, sobre os quais jaziam couros de boi e de cervídeos em que os Eyiguayegui e seus cativos dormiam ${ }^{32}$.

Segundo Sánchez-Labrador ([1770-1776], v. I:42), se o número de parentes e de criado(a)s era muito grande, construía-se outro toldo, que era anexado ao do capitão. De acordo com as crônicas, as tolderias eram constituídas, assim, por um capitão "grande" e sua esposa, filho(a)os e cativo(a)s, que se dividiam pelos toldos adjacentes ao seu. Quando um homem se casava, ia morar no toldo de sua esposa, salvo nos casos em que os capitães se casavam com as capitãs Guaná, que nessas situações passavam a morar com seu marido, trazendo consigo seus próprios "escravos".

Os conjuntos de tolderias, por sua vez, formavam o que Sánchez-Labrador denominou parcialidades ${ }^{33}$ ou capitanias que, na época do missionário, eram quatro e estavam situadas nas duas margens do Rio Paraguai. Como vimos, o missionário instalou sua missão entre as parcialidades dos Apacachodegodegis e Lichagodegis, que viviam no lado ocidental daquele rio, e se dividiam em aproximadamente dez tolderias. O critério utilizado pelo missionário para a delimitação das parcialidades - e mesmo de outros tipos de grupos sociais, como as "nações" 34 - parece ser o das coalizões motivadas pela guerra, quando algumas tolderias se uniam sob o "comando" de apenas um capitão, com um inimigo em comum. É interessante notar que, assim como o termo tolderia, parcialidade também parece descrever muito bem o contexto chaquenho (e ameríndio) de conexões e alianças contextuais, que variam em "tamanho, duração e

\footnotetext{
${ }^{31}$ Boggiani ([1895]:86); Sánchez-Labrador ([1770-1776], v. I:272).

32 Sánchez-Labrador ([1770-1776]); Rivasseau (1936).

33 De acordo com Richard e Combès (2015:232), parcialidade designa geralmente "grupos indígenas considerados 'parte' de um grupo maior, assim como uma 'tribo' pode ser parte de um 'grupo étnico'”. A suposição da unidade étnica, nos contextos ameríndios, esbarra, como aqui, na chamada flutuação de alianças e inimizades que teriam de ser consideradas "intra-étnicas"; veja-se a análise de Fernandes (2006).

${ }^{34}$ Mesmo a denominação dos grupos sociais que hoje podem ser denominados "povos" variou ao longo da história chaquenha. Segundo Richard (2011), no século XVI eles eram referidos como "generaciones"; no XVIII como "naciones" e no XIX como "tribos".
} 
finalidade" 35 - melhor do que termos como bando, grupo local, tribo ou sociedade, correntemente usados por antropólogos e historiadores.

No mais, o termo parcialidade, tal como delimitado por Sánchez-Labrador, exprime também uma ideia formulada por Sterpin (1993: 52) sobre os Nivacle, habitantes do médio Pilcomayo do Chaco: a de que a guerra e as borracheiras (sempre em conjunto) definem as marcações temporais, espaciais e sociais chaquenhas ${ }^{36}$. No mesmo sentido, Perrone-Moisés (2015: 76) afirma que as "aldeias" ameríndias (ou tolderias no caso chaquenho) constituem "turmas de festa e de guerra", delimitadas contextualmente de acordo com os convidados e/ou com os inimigos, pois sem o outro, como afirmávamos, não há grupos, nem tolderias ou parcialidades. Portanto, ainda que falar em "partes” possa nos levar a pensar num “todo" virtual, o que não se aplica, mantenho aqui esses termos empregados já pelos primeiros cronistas e com eles a variação constante dos grupos conforme os contextos, que os termos correntes não permitem perceber.

Ainda que fossem definidos pelos relatos coloniais como povos nômades, que não paravam "mais que dois dias num mesmo lugar" ${ }^{7}$, os Eyiguayegui seguiam um certo ritmo em suas mudanças sazonais e no estabelecimento de suas tolderias, que eram instaladas, durante o inverno seco - entre meados de maio até início de setembro -, aos pés das serras do pantanal. Esses acampamentos de inverno acompanhavam os cursos dos rios, que têm seus volumes significativamente reduzidos nessa época do ano ${ }^{38}$, e aproveitavam da maior facilidade da pesca nessa estação e da caça de jacarés e capivaras. Quando a estação chuvosa retornava, os Eyiguayegui subiam as serras, instalando-se nas terras planas, onde havia espaço para a criação dos bois, ovelhas e cavalos, e dedicavam-se à caça de animais como os cervídeos, antas, porcos do mato, lobos e onças de pequeno porte. Os pontos de acampamento dos Eyiguayegui eram, portanto, “[ [... sucessivamente abandonados e reocupados, segundo a estação e o crescer ou diminuir dos frutos e da caça" ${ }^{9}$.

De acordo com Almeida Serra (1850:213),

[a]lém d'estas repetidas e annuaes mudanças para o pasto de tantos animaes, e para a pesca e caça [...], faz[ia]m os Uaicurús outras muitas e diversas digressões para acharem em outros logares

\footnotetext{
${ }_{35}$ Perrone-Moisés (2015: 76).

${ }^{36}$ Segundo a autora, é no período do ano em que se coleta a algarroba que se faz a cerveja. As bebedeiras ocasionadas por ela, por sua vez, trazem consigo uma exaltação à guerra e, consequentemente, as expedições guerreiras.

37 Cabeza de Vaca $([1555]: 150)$.

38 Almeida Serra (1850: 212).

${ }^{39}$ Rodrigues do Prado (1795:66).
} 
sustento e palmitos, maiormente no tempo em que a bucayuba, espécie de palmeira, dá o seu fructo, do qual fazem durável provimento, tanto da polpa, como do côco que ella cobre (...).

A palma "bucayuba" era conhecida pelos Eyiguayegui como namoculi e utilizada na alimentação e nas borracheiras. Não está suficientemente clara na literatura a relação ou as diferenças entre as palmas namoculi e eyiguát ${ }^{40}$, mas elas parecem ser dois tipos parecidos que eram utilizados para fins similares. Em conjunto com a coleta da namoculi ou eyiguá, era feita também a coleta do mel, muito apreciado por aqueles índios, que o consumiam durante suas refeições e o submetiam a um processo de fermentação que durava três ou quatro dias e que o transformava em bebida alcóolica, assim como aquelas palmas. Essa bebida - denominada nudagi - era consumida durante as célebres borracheiras, descritas pela documentação colonial como "quase transcendentais" 4 , por conta da propriedade alucinógena do vinho produzido da mistura de mel com algarroba. Nessas ocasiões, tanto homens quanto mulheres se sentavam em cima da pele de cervos e bebiam por horas fio, até serem carregados de volta a seus toldos para descansarem e então voltarem para a bebedeira ${ }^{42}$.

Além de ser usado para cobrir os jiraus dentro das tolderias, como mencionado, o couro de cervo e de outros animais era utilizado em diversas ocasiões: nas borracheiras, nas cantorias, nos tratamentos de cura realizados pelo unigene e até como canoa portátil para transportar alimentos e objetos na travessia dos rios. As produções atuais acerca dos Kadiwéu afirmam que esses couros eram (e ainda são) pintados com os mesmos motivos utilizados na pintura corporal feita pelas mulheres. Eles parecem, nas ocasiões das borracheiras, marcar a posição das pessoas que se sentam em roda e bebem. Durante essas festas, existem momentos em que canções chamam determinadas pessoas a ocupar seus lugares em cima do couro ${ }^{43}$ (Lecsnieski 2005:206).

\footnotetext{
${ }^{40} \mathrm{E}$ isso mereceria ser objeto de uma investigação de campo junto aos Eyiguayegui.

${ }^{41}$ Sánchez-Labrador ([1770-1776], v. II:6).

${ }_{42}$ Desenvolverei as descrições sobre as borracheiras no capítulo 3.

${ }^{43}$ A literatura especializada não se detém em análises sobre os couros, mas é perceptível sua importância em diversos momentos da vida social eyiguayegui. É digno de nota também o fato de que, entre os Nivacle ou Chulupi do Chaco central, o couro é um dos distintivos da nobreza do caanvacle, nobre guerreiro (ver Sterpin 1993).
} 


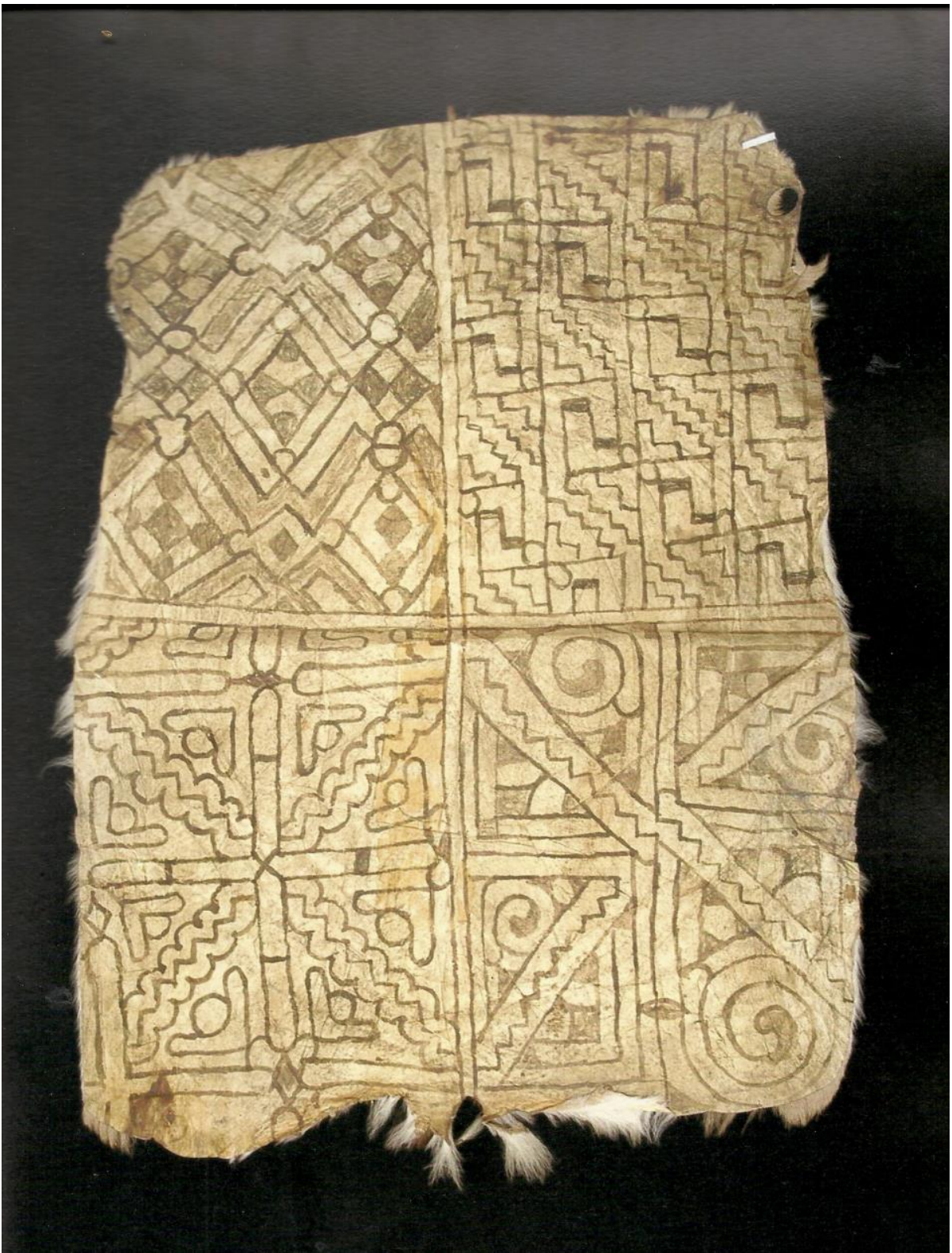

Fonte: Schwarcz \& Pedrosa (2015: 271).

Segundo Claude Lévi-Strauss (1996:189), que pôde presenciar uma bebedeira por ocasião de uma "festa da moça" durante sua curta estadia entre os Kadiwéu, nessas famosas festas "os chefes se sentavam de acordo com seu nível, [e eram] servidos pelos escudeiros, enquanto os arautos enumeravam os títulos do bebedor e recitavam suas façanhas”. A posição ocupada por capitães e cativos, homens e mulheres, marcada muitas vezes pelo couro, costuma ser determinada de acordo com o "nível” das pessoas, assim como os lugares dentro das tolderias que, como veremos, é seccionada em 
lugares de capitães e cativos. Em ambos os casos, as relações entre "nobres" e "escravos" encontram ecos na organização espacial eyiguayegui ${ }^{44}$.

1.2.2 Niniotageleudi, niniotagilionigi, uneleiguá, nibotagi, niyolola: distinções eyiguayegui

"Nobres”, “escravos”, “cativos”, “capitães” e "servos” são outros daqueles termos trazidos pela literatura do século XVIII, mas não apenas por ela. Fala-se em hierarquia eyiguayegui desde Ulrich Schmidel, no século XVI. Mas, novamente, a melhor descrição dessas relações é a de Sánchez-Labrador. Por meio de seus diários, recebemos a notícia de que os Eyiguayegui dividiam-se em três camadas supostamente endogâmicas: “capitães” (os “senhores” ou “nobres"); "plebeus” (ou "gente comum”); e os "escravos" e "servos"45. A primeira compunha-se de dois tipos de capitães: os niniotageleudi, capitães grandes, e os niniotagilionigi, capitães de segunda classe, que recebiam o título em situações especiais, como por exemplo por nascerem no mesmo dia que um capitão grande. O título dos primeiros era hereditário, e o dos segundos, apenas vitalício. A segunda camada era formada pelos uneleiguá, os Eyiguayegui “comuns", ditos "misturados" 46.

Havia, ainda, a camada daqueles que boa parte dos cronistas chama de "escravos", os nibotagi. Em seus ataques, os Eyiguayegui tomavam mulheres e crianças como cativos e, em geral, aniquilavam os homens adultos. Índios, brancos ou negros, mas nunca pessoas nascidas de pai e mãe eyiguayegui, os estrangeiros capturados, apartados de suas famílias e costumes, serviam aos "senhores" em atividades domésticas, na lavoura, na construção de canoas, toldos, no abastecimento de água e lenha e, ainda, como bens de troca em negociação com outros grupos ${ }^{47}$. Além dos nibotagi, também faziam parte dessa terceira classe aqueles que a literatura colonial reconhece como "servos", as populações servis ou tributárias chamadas pelos Eyiguayegui de niyolola ${ }^{t s}$.

\footnotetext{
${ }^{44} \mathrm{O}$ mesmo acontece, por exemplo, no Conselho dos Sachems iroques (Morgan 1851) e nas festas da Columbia Britânica (Boas 1925: passim), onde cada participante tem seu lugar de sentar (e falar e/ou comer) demarcado conforme seu nome/família.

${ }^{45}$ Desenvolverei mais profundamente a descrição dos estatutos eyiguayegui no próximo capítulo. No momento, pretendo apenas apresentar um panorama de como a "organização social" eyiguayegui foi descrita ao longo do tempo.

${ }^{46}$ Sánchez-Labrador ([1770-1776], v. I: 273).

${ }^{47}$ Sánchez-Labrador ([1770-1776], v. I:90).

${ }^{48}$ Sánchez-Labrador ([1770-1776], v. I:130).
} 
É importante atentar para o fato de que a maioria das crônicas, ao contrário de Sánchez-Labrador, tende a descrever a hierarquia eyiguayegui sem dividir a "parte" 49 dos cativos em "escravos" e "servos": todos figuram como "cativos", "cativeiros" ou mesmo "escravos". Ainda assim, como notado acima, o relato de Sánchez-Labrador (e sua diferenciação entre servos e escravos) é o mais utilizado pelos estudos atuais acerca da já assente "hierarquia" daqueles índios, por levar em consideração um fato central: os próprios Eyiguayegui designavam uns como niyolola e outros como nibotagi. De modo a dialogar com essa literatura, seguirei discutindo a diferenciação entre "escravos" e "servos", que foi afirmada e reconfigurada posteriormente pela antropologia e interpretada como resultado de dois fatores.

O primeiro elemento de diferenciação entre nibotagi e niyolola, segundo fontes históricas e antropólogos, é o caráter da relação - individual ou coletivo - que esses tinham com seus "senhores". Ao contrário dos nibotagi, cuja relação com os capitães era individual - ou seja, entre um niniotageleudi, niniotagilionigi ou uneleigá e seu nibotagi-, a relação dos niyolola com os oquilidi - "senhores" - é muitas vezes entendida como coletiva, ou seja, entre duas sociedades diferentes ${ }^{50}$. Essas populações, por sua vez, eram divididas em "guerreiras" e "agricultoras", categorias às quais eram relacionados os Eyiguayegui e os Guaná respectivamente. A essa divisão está atrelada a hipótese de que os Guaná seriam, em sua essência, populações servis que teriam evitado a luta com os Eyiguayegui, preferindo entabular com estes uma relação de servidão ${ }^{51}$, ao passo que os Eyiguayegui seriam, também em sua natureza, povos de gênio extremamente belicoso. Os Guaná, nesse sentido, são descritos pelas fontes como predispostos à servidão, pois eram "pacíficos" e "submissos" (qualidades que acompanhariam sua “índole agrícola”), de modo que os "ferozes" Eyiguayegui não tardaram em subjugá$\operatorname{los}^{52}$. De acordo com Aguirre (1898:472), militar espanhol responsável pela delimitação das fronteiras entre o Brasil e o Paraguai, em contraposição aos Eyiguayegui, índios guerreiros e cavaleiros, os Guaná eram “[ ...] índios labradores, de a pie, dóciles [...]”,

${ }_{49}$ O termo "parte" (discutido adiante) é utilizado por Rodrigues do Prado (1795) para se referir aos diferentes estatutos eyiguayegui. Ainda que remeta virtualmente a um "todo", o que, novamente, não se aplica, o vocábulo parece interessante por não evocar nenhuma relação de inferioridade como acontece com os termos "classes", "camadas" ou "estratos", muitas vezes utilizados pelos documentos.

50 De acordo com Baldus, em seu Dicionário de Etnologia e Sociologia (1939:204, grifos do autor), por "servidão" deve-se entender "uma relação de dependência muito mais frouxa e muito menos individual entre uma camada inteira e uma outra sobreposta isto é, uma aristocracia”. De forma parecida, SantosGranero (2009: 81, tradução minha) considera o fato de que as populações servis eram "subjugadas coletivamente e não individualmente" como uma de suas principais diferenças em relação aos cativos.

${ }^{51}$ Quanto à servidão ser relacionada com um certo tipo de atividade, a agrícola, ver adiante, capítulo 2.

52 Sánchez-Labrador ([1770-1776], v. I:267). 
que tinham em si um desejo de servir ${ }^{53}$. Segundo Almeida Serra (1850: 208), os Eyiguayegui, "estragando-lhes as suas plantações, e espreitando-os tanto nas suas roças, como quando iam e voltavam d'ellas; ou no campo matando e captivando os que apanhavam em descuido", haviam levado os Guaná a "pedirem-lhes paz, e a deixaremse chamar seus captiveiros, dando-lhes voluntariamente parte de suas colheitas, para pouparem o resto, e as mortes que cada anno sofriam”. O fato de os Guaná terem se rendido aos Eyiguayegui por conta do seu gênio "dócil”, quando poderiam ter enfrentado aquela nação guerreira confere um certo tom de "servidão voluntária" ${ }^{44}$ a essa relação, ponto ao qual voltarei adiante.

O segundo fator de diferenciação entre "escravos" e "servos" estaria na diferença do grau de liberdade concedida aos niyolola. Mesmo que "servos" e cativos de guerra fossem submetidos aos ataques constantes dos guerreiros eyiguayegui e a seu poder coercitivo, os grupos servis teriam uma margem de escolha muito maior que aqueles índios (ou europeus) raptados (ver Susnik 1971, 1972; Métraux 1946, Baldus 1975 e Santos-Granero 2009). Segundo Santo-Granero (2009: 81), ao contrário dos cativos, os servos não eram deslocados de suas terras, podendo manter suas famílias, laços de parentesco e liderança. O preço dessa autonomia concedida aos Guaná, segundo essa hipótese, seriam os "tributos" agrícolas pagos pelos "servos" a seus "senhores" nas visitas realizadas pelos últimos às aldeias guaná, descritas adiante.

A premissa de que uma sociedade poderia subjugar a outra aliada à interpretação de que a diferença entre os nibotagi e os niyolola é o grau de liberdade a eles oferecido parecem se originar de concepções de poder e de sociedade específicas. E é importante notar que, na base dessa construção teórica da diferença entre "escravos" e "servos" encontra-se a suposição (presente tanto nas fontes quanto em obras antropológicas contemporâneas) de que “os Eyiguayegui”, em sua totalidade, teriam dominado "os Guaná”.

A elaboração dessa ideia de dois organismos diferentes relacionados por uma gradação hierárquica é o tema das próximas páginas, nas quais ilumino as trilhas percorridas pelos documentos e antropólogos na construção dessas fronteiras. Demonstrarei como esses caminhos estavam permeados por ideias essencialistas (quando as fontes definem a "índole" de cada sociedade, por exemplo) e mesmo

\footnotetext{
${ }^{53}$ Esse rótulo de "pacíficos" e "parceiros" ecoa até os dias de hoje e foi base de políticas indigenistas que tentaram transferir famílias Terena e Kinikinau (auto-denominados descendentes dos Guaná) para o oeste paulista, a fim de "civilizar" e "servirem de exemplo" para os Guarani-Kaiowá e os Kaingang (Franco 2011: 16).

54. Ver La Boétie (1987); Clastres (2004).
} 
evolucionistas (quando antropólogos consideram os "agricultores" Guaná mais avançados que seus vizinhos Eyiguayegui, "simples" caçadores e coletores, e associam "povos agricultores" a "povos pacíficos"). O esfacelamento dessa dicotomia, em conjunto com a problematização da ideia mesma de "nação" ou "sociedade" fundamento da noção de servidão - faz emergir fatos que contradizem claramente o conceito de hierarquia suposto em tais descrições e análises, improdutivo quando se trata de pensar o Chaco $^{55}$.

\subsection{0 “complexo hierárquico” Eyiguayegui - Guaná}

1.3.1 Ideários nacionalistas, sociedades e poder: a definição dos contornos eyiguayegui e guaná

Discuti acima a dificuldade de delimitar os "grupos sociais" chaquenhos. De saída, portanto, podemos considerar no mínimo complicada a afirmação de que uma "nação" domina a outra. Onde estaria o limite entre essas populações?

As mesmas complicações em determinar os grupos Guarani, Guaicurú, Mbayá ou Eyiguayegui são encontradas quando tentamos definir os contornos dos "povos Guaná”. O termo "Guaná” surgiu no século XVIII para designar os Chané 56 - povos de língua arawak chaquenhos - situados na franja oriental do Chaco, próximos ao Rio Paraguai ${ }^{57}$. Segundo Sánchez-Labrador ([1770-1776], v. II:267), o etnônimo é, na verdade, fruto de uma confusão:

Guaná en idioma de los Chanás es pronombre relativo de tercera persona, esto es, aquél. Preguntaría algún Español, viendo á estos indios: ¿quién és aquél? Y le responderían: Guaná; y de aquí o de cosa semejante vendrá atribuir á toda la nación Chaná el nombre de Guaná.

Em sua sistematização dos dados chaquenhos, Alfred Métraux propôs chamar os Arawak do piemonte andino de Chané e os das margens do Rio Paraguai de Guaná, classificação que persiste até os dias de hoje $\mathrm{e}^{58}$ e que adotarei neste trabalho. É interessante notar que a "confusão" descrita por Sánchez-Labrador parece se multiplicar no Chaco: os etnônimos nunca designam "nações" bem definidas, como vimos, e sim qualificam relações. Também atento a esse desencontro de conceitos,

\footnotetext{
55 Inequado, ao que tudo indica, para pensar qualquer forma ameríndia de relação entre "diferenças sociais"; ver Perrone-Moisés \& Lolli (2017).

${ }_{56}$ Também designados Chaná. Grupos arawak que habitavam o Chaco boliviano, aos pés dos Andes, e o Alto Paraguai. Suas aldeias eram próximas aos locais em que Eyiguayegui foram encontrados nos primeiros registros apresentados acima (ver mapa 1).

${ }^{57}$ Richard e Combès (2015:232).

${ }^{58}$ Richard e Combès (2015:232).
} 
Félix de Azara (1809: 225), comissário e comandante das fronteiras espanholas no Paraguai de 1781 a 1801 , se queixa:

Se pergunta a eles se são de diferentes nações dirão que sim, mas porque não sabem o que é uma nação e creem que cada horda forma uma diferente. Consequentemente, indicam o lugar de cada horda e daí procede que de uma única nação dos Guaná se tenham feito todas as que figuram nos mapas.

O desencontro das maneiras indígenas e europeias de pensar a socialidade, claramente demonstrado na citação de Azara, permeia grande parte das narrativas sobre as relações entre aquilo que convencionamos chamar "grupos" do Chaco. A categoria "nação", referida no excerto acima e utilizada por muitos autores do século XVIII, parece remeter a um projeto ideal de organização social ${ }^{59}$ : no ideário europeu da época, uma nação era constituída por uma língua, uma cultura e um território. Visualizando no Chaco organizações que pareciam se encaixar nessa definição, os autores das fontes tendem a interpretar os conflitos chaquenhos como guerras "intranacionais”, que seriam resultado da ignorância indígena acerca de suas próprias formas de organização social ${ }^{60}$.

Fundamentadas na ideia de que as populações chaquenhas podiam ser divididas em nações (ainda que ignorassem esse fato), muitas fontes utilizam-se de um componente intrínseco a essa forma de organização social para diferenciá-las: aquilo que elas chamam de "índole”, que talvez possa ser comparado a algo como o "espírito" de cada nação. As “índoles” guaná e eyiguayegui, nesse sentido, são usualmente mobilizadas nos momentos em que as fontes opõem uma "nação" a outra. Nesse sentido, de acordo com os documentos, os Eyiguayegui, de um lado, seriam povos essencialmente guerreiros e a adoção dos cavalos teria aumentado seu aparato bélico e mesmo sua "vocação" para a guerra. De outro, os Guaná seriam fundamentalmente pacíficos, tendo como principal preocupação a manutenção de suas roças, e teriam um pendor pela servidão. Essas diferentes "índoles", por sua vez, acabariam por reforçar as "fronteiras nacionais" percebidas pelos documentos, demarcando as diferenças entre uma população e outra.

\footnotetext{
59 A “ideologia nacionalista” europeia da época entendia "nação" como a forma mais razoável (no sentido de baseada na "Razão") de organização social, considerando-a, portanto, o destino de todos os povos. Foi essa certeza da "iluminação" que permitiu aos europeus que aqui aportaram afirmarem, de um lado, a ignorância dos povos americanos (que não saberiam tanto quanto eles por não terem atingido a "Razão") e, de outro, desenvolverem projetos de colonização e civilização das populações consideradas inferiores. ${ }^{60}$ Em comunicação pessoal, a Prof ${ }^{a}$ Beatriz Perrone-Moisés notou que o mesmo descompasso afeta os documentos sobre Tupi da Costa: nesse caso, algumas fontes chegam a falar em "guerras civis"; como se as "hordas" de algo que parece caber num certo conceito de nação não entendessem mesmo qual o conceito e o projeto (supostamente universais) de se constituírem enquanto tal. Note-se que já em 1904 Marcel Mauss discutia as possibilidades e consequências de empregar termos como nação nos estudos de populações não-ocidentais - no caso, ao que chama de “sociedades esquimós” (Mauss 2003: 425).
} 
Já alguns antropólogos, como Alfred Métraux (1946), Branislava Susnik (1971; 1972) e Paul Radin (1948), delimitam os grupos indígenas chaquenhos por meio dos tipos de "economia" e de "organização social”. Esses critérios de classificação parecem ecoar - no caso de Métraux de forma mais óbvia, visto que contribui para seus volumes - a tipologia basilar da série Handbook of South American Indians (1936-1948) idealizada e organizada pelo americano Julian Steward. Em linhas gerais, o projeto tratava de estudar as "variações de tamanho e composição" das unidades sociais dos indígenas sulamericanos, "reportando-as sempre às atividades de subsistência e aos modos pelos quais tais unidades - sociedades - organizavam-se para realizá-las - perguntando-se, sobretudo, quanto à existência ou (im)possibilidade de produzir excedentes" (Drago 2012: 16, grifos do autor). Os tipos culturais em que foram classificadas as sociedades estudadas e que fundamentaram a divisão dos volumes da coletânea eram alinhavados por uma lógica na qual "algumas instituições seriam necessariamente anteriores a outras" (Drago 2012: 16). Grupos pequenos de caçadores-coletores, vistos como reminiscências de um período pré-agrícola politicamente rudimentar, estariam logicamente em desvantagem diante de grupos horticultores demograficamente mais expressivos, possíveis geradores de excedentes e, portanto, de classes sociais diferenciadas e centralização do poder - indicativos de um bom desenvolvimento ${ }^{61}$.

Em sua contribuição ao volume dedicado às "tribos marginais" do HSAI (1946), Métraux dividiu os povos chaquenhos seguindo um raciocínio parecido: primeiramente, haveria os indios pedestres ("bandos" de caçadores e coletores seminômades); depois os índios cavaleiros e canoeiros (categoria constituída por aqueles "bandos" seminômades que teriam passado por um desenvolvimento econômico trazido pelos cavalos e canoas) e, por fim, a família linguística arawak (populações maiores, agricultoras e sedentárias). A família linguística é distinguida nesse último caso porque Métraux levanta a hipótese de que essas populações teriam influências culturais andinas, distinguindo-se (em todos os sentidos) dos outros tipos culturais chaquenhos, considerados muito mais simples tanto econômica quanto politicamente.

Nesse sentido, a demarcação antropológica da fronteira entre "os Eyiguayegui” e "os Guaná", de maneira bem parecida com a das fontes, seria aquela entre povos (caçadores-coletores) cavaleiros e povos Arawak agricultores. Os Eyiguayegui eram tidos - tanto pelos documentos históricos quanto por antropólogos - como uma

\footnotetext{
${ }^{61}$ A América foi dividida, no HSAI, entre os povos de tipo "Marginal" - categoria à qual pertenciam os grupos chaquenhos -, os grupos horticultores da "Floresta Tropical", o "Circum-Caribe e o Sub-Andes" e, por fim, os "Andes". Sobre a classificação dos povos nos 7 volumes do HSAI, ver Faron e Steward (1959) e Drago (2012).
} 
"nação" subdividida em parcialidades unidas contextualmente e formadas por tolderias que eram demograficamente pouco densas, visto que precisavam se deslocar, ao longo das estações, em busca de provimentos. Os aldeamentos Guaná, ao contrário, foram sempre descritos como os mais densos da região, com uma população entre 20.000 a 45.000 pessoas - o "país chaná" se estendia, de acordo com os antropólogos Richard e Combès (2015:236), entre Corumbá, no Brasil, e o Forte Olimpo, no Paraguai62. Também de forma antagônica aos Eyiguayegui, os Guaná não se deslocavam periodicamente pelo território chaquenho, segundo os documentos: eles eram um povo considerado essencialmente agricultor e permaneciam longos períodos em um mesmo lugar. O "argumento de peso" mobilizado por grande parte da literatura especializada bebia dessa dicotomia: segundo a hipótese clássica ${ }^{63}$, os "dóceis agricultores arawak [...] teriam sido submetidos e dominados por grupos guerreiros [...] que os subordinaram à força até fundi-los em uma sociedade duramente hierarquizada" (Richard e Combès 2015:232).

Essa visão dicotômica e fixa das duas "populações”, porém, encontra diversos obstáculos na literatura colonial que, mesmo permeada por essa perspectiva, traz diversos relatos que a questionam, como veremos adiante. A própria etnologia americanista criticou esse tipo de interpretação dos dados presentes nas fontes históricas, apoiando-se em exemplos de sociedades ameríndias consideradas até então materialmente pobres mas socialmente complexas, que desafiavam esse tipo de leitura $^{64}$. Mesmo os Eyiguayegui desafiam esse modelo: seu refinamento político, multiplicador de categorias sociais, é uma afronta à sua classificação como "povos marginais" e não combina com a imagem de "caçadores-coletores", tal como definida pelo HSAI. Também a presença, em uma área denominada "marginal", de populações agricultoras com "influências andinas" e consideradas por Métraux (1946: 211) mais desenvolvidas coloca questões a esse modelo. Mais desafiador ainda é o fato de pequenos "bandos" de caçadores-coletores "subjugarem" grandes povos agricultores

\footnotetext{
${ }^{62}$ A descrição das "vilas" guaná efetuada por Sánchez-Labrador ([1770-1776], v. II:25) são um exemplo da grandiosidade transmitida pela literatura quando se trata de se referir aos "índios agricultores". Segundo o missionário, as "vilas" eram "[ ...] población formada en calles divididas en cuadras, y en medio tiene una plaza muy grande, más larga que ancha. La gente de este pueblo es mucha, y pasará de 800 famílias, todos son labradores y se mantienen del fruto de sus sementeras, en que semean e plantan lo necesario para vivir con menos miseria [...]” (p. 25).

${ }^{63}$ Susnik (1971: 35), por exemplo, afirma que, no encontro entre Eyiguayegui e Guaná, enfrentaram-se duas "pautas distintas, la de los cazadores-guerreros con plena consciência de ser advenedizos y que la hostilidad era su fuerza 'de derecho', y la de los cultivadores deseando conservar su unidad aldeana y también protegerse contra peligros periféricos; se estableció así entre las dos tribus una relación de convivencia político-tribal, llamada por los cronistas generalmente 'vasallaje".

${ }^{64}$ Ver, por exemplo, "A noção de arcaísmo em etnologia", de Lévi-Strauss (2012).
} 
tidos por mais "desenvolvidos" nessa classificação. Ao tentar contornar essa questão, Métraux encontra duas explicações: em primeiro lugar, a adoção do cavalo trazido pelos europeus, que lhes teria possibilitado dominar o Chaco praticamente em sua totalidade ${ }^{65}$. Em segundo, o "empréstimo cultural" da hierarquia arawak, resultante da "simbiose" entre os dois povos, como veremos adiante. Interessante notar que os dois motivos considerados por Métraux são exógenos à "cultura mbayá-guaicurú", que não teria, na visão do antropólogo, meios materiais para desenvolver por si só diferenciações sociais tão complexas.

Essa linha evolucionária de interpretação dos dados chaquenhos é abandonada pelo antropólogo Fernando Santos-Granero (2009: 42), que não considera indicativos como a prática da agricultura e a produção de excedentes como evidências de um maior desenvolvimento. De acordo com o autor, Eyiguayegui e Guaná estavam imersos em um sistema regional heterogêneo ${ }^{66}$, ou seja, um complexo regional formado por sociedades com tamanhos, complexidades e habilidades militares diferentes (Santos-Granero 2009: 18). Em contraste com os sistemas regionais homogêneos - onde as sociedades teriam capacidades militares parecidas -, aqueles tinham como principal característica a (tentativa de) dominação de um grupo por outro. Portanto, segundo Santos-Granero, "a distinção entre povos dominantes e subordinados nesses sistemas regionais de poder é menos aquela entre sociedades guerreiras e pacíficas e mais aquela entre sociedades mais e menos poderosas” (Santos-Granero 2002: 42, tradução minha).

Mesmo rejeitando certos padrões socioeconômicos (como o "desenvolvimento da agricultura”) como evidências da superioridade de uma população e da inferioridade de outras, portanto, Santos-Granero acaba por considerar outros desses padrões em sua análise. Segundo o autor, a subsistência e a "capacidade bélica” influenciavam a configuração desses sistemas na medida em que faziam uma população ser mais poderosa que a outra. De acordo com Santo-Granero (2009: 43), todas as populações

\footnotetext{
${ }^{65} \mathrm{O}$ cavalo, segundo Métraux, teria estimulado um gosto pela guerra anterior à invasão europeia, e desenvolvido uma hierarquia antes incipiente. Sobre a guerra, ver capítulo 3. Sobre esse gosto dos Eyiguayegui pelas diferenciações sociais - denominada por Métraux hierarquia -, considero oportuno dizer, assim como Viveiros de Castro o fez sobre a guerra entre os Tupinambá, que "era um dado irredutível dessa sociedade, sua condição reflexiva e seu modo de ser, que, se foi potencializado pela introdução de objetos estrangeiros e eventualmente explorado pelos europeus, não foi posto lá por eles" (Viveiros de Castro 2002: 246).

66 Santos-Granero se baseia na diferenciação proposta por Patrick Menget (1985: 135-5) entre sistemas regionais homogêneos (em que os grupos relacionados não diferem muito em suas noções cosmológicas e sociológicas, além de terem “naturezas” parecidas) e sistemas regionais heterogêneos (unidades de tipos diferentes, seja porque eles não tenham a mesma cultura nem os mesmo objetivos, seja porque o sistema inclui sociedades de naturezas diferentes).
} 
dominantes de complexos regionais como esse ${ }^{67}$ tinham em comum o fato de habitarem as regiões mais férteis e o autor considera o fato de os Eyiguayegui morarem às margens do Rio Paraguai, o maior da região, com solos ricos e fontes aquáticas uma evidência de seu argumento. Além de ser entendido como uma das bases para o poder de alguns grupos, o território é também visto por Santos-Granero como um dos motivos da servidão: as migrações em busca de territórios mais férteis trariam, por sua vez, mais poder. Segundo o autor, muitas relações de servidão na América tropical começavam por conta das migrações dos grupos poderosos para territórios de grupos mais fracos. Estes últimos, sem querer sair de seus territórios, preferiam ficar como servos (Santos-Granero 2009: 66). Os contornos dos Eyiguayegui e Guaná são delineados por Santo-Granero, portanto, por meio da concepção de poder (apoiada em fatores econômicos): a população mais forte - porque ocupa os territórios mais férteis domina a mais fraca.

Os dados presentes nas fontes coloniais colocam problemas para todas essas análises, fundadas em “índoles", "tipos culturais" ou "sistemas regionais de poder". Em primeiro lugar, o aparente expansionismo guaná em direção ao interior chaquenho (discutido adiante), sua participação nas guerras chaquenhas e sua estratificação social são evidências de que os Guaná não podem ser qualificados como povos de "natureza pacífica”, democráticos (em oposição aos Eyiguayegui) e nem mesmo menos poderosos. Além disso, os casamentos entre capitães eyiguayegui e capitãs guaná contribuem para dificultar uma delimitação exata desses dois "grupos”, o que certamente influi na “dança dos etnônimos” já mencionada. Por fim, as negociações e movimentos contrahierárquicos presentes nessas relações, cuja compreensão depende de suspendermos pressupostos quanto à economia, à política e a tipos de organização social como os que vêm sendo aplicados por observadores e analistas ao longo dos séculos, são suficientes para nos fazer rever os fundamentos deste "complexo hierárquico" - denominação de Combès, Lowrey e Villar (2009: 73) ao sistema de relações entre esses dois "blocos". Vamos aos dados.

\footnotetext{
${ }^{67}$ Santos-Granero compara os Eyiguayegui a outras sociedades que ele classifica como guerreiras: os Chiriguano, no Chaco boliviano; os Kalinago, nas pequenas Antilhas das Bahamas; os Conibo, no leste do Peru; os Tukano no Alto Rio Negro e os Calusa no golfo do México.
} 


\subsubsection{Colonialismo Guaná}

$\mathrm{Na}$ época das primeiras viagens dos exploradores espanhóis, as habitações eyiguayegui e guaná eram, como vimos, vizinhas. Em uma análise extremamente cuidadosa dos diários de Sánchez-Labrador, os antropólogos Isabelle Combès e Nicolas Richard (2015) percebem ter havido um padrão nos modos de habitação desses povos: os aldeamentos que o jesuíta identificou como guaná e que seguiam o curso do rio Paraguai estavam sempre em pares. Ao visitar uma vila Terena (entendida pelo missionário como uma "parcialidade” guaná), por exemplo, o missionário se deparou com uma aldeia vizinha, a "dos Echoaladi”, que ora aparecem na literatura como outra parcialidade guaná, ora como "escravos" dos Terena. Em outro momento, ele se depara com pares de aldeamentos Terena e Layana, cujo etnônimo dá margem ao mesmo questionamento. E os diários do jesuíta não trazem apenas essa revelação: depreende-se de sua leitura que, “[s]e é verdade que sobre a margem ocidental do rio, as aldeias chaná distribuem-se de duas em duas, para cada um desses pares corresponde, sobre a outra margem do rio, um acampamento mbayá” (Richard e Combès 2015:238).

Temos aqui uma cadeia de relações que nos é apresentada de acordo com o posicionamento dos autores das fontes. Quando em contato mais próximo com os Guarani, tendem a chamar os Eyiguayegui de Guaicurú (“sarnentos”). Esses Guaicurú, habitantes das fronteiras chaquenhas, ou das zonas "intermediárias" entre o espaço recém-ocupado pelos europeus e o centro do Chaco, têm suas tolderias erguidas próximas aos aldeamentos denominados pelos documentos Guaná, cujos habitantes são chamados por eles (em língua Guaicurú) niyolola. Como já notado, as fontes muitas vezes traduzem niyolola por "servos” ou “escravos”, tradução em si duvidosa, que parece ter mais a ver com a interpretação europeia das relações chaquenhas do que uma similaridade entre a relação de "servos"/"escravos" e "senhores" e aquela entre niyolola e oquilidi (como eram chamados os eyiguayegui pelos niyolola). Seguindo sempre a oeste, em direção ao interior do Chaco, encontramos os vizinhos dos niyololas, os Echoaladi, termo também traduzido para “escravos”, mas dessa vez em língua arawak, a língua dos Guaná. Em outros casos, perto dos Guaná encontravam-se os Chamacoco, também entendidos como "escravos", segundo os autores das fontes. Além de demonstrar, mais uma vez, a profusão de etnônimos que podem ser encontrados nos documentos históricos, essa "cadeia de nominação"68 aponta também outro fato: não

\footnotetext{
${ }^{68}$ A expressão é de Richard (2008: 221).
} 
eram apenas os Eyiguayegui que estavam a fazer "servos" na época da invasão, mas também seus "vassalos" Guaná69.

Mais uma vez fundamentados nos diários de Sánchez-Labrador, Richard e Combès nos mostram como as grandes populações chané e guaná (entendidas como as mais populosas da região, como mencionado) foram consideradas uma totalidade pelas fontes, mas pareciam mesmo ser formadas por diferentes coletivos. De acordo com os autores (Richard e Combès 2015:234), "Chané" é um termo arawak que pode ser traduzido como "gentio" ou "multidão". Gentes diferentes eram chamadas de "chané" por índios denominados "guaná" pelos autores das fontes não porque formavam todas uma mesma "nação", mas porque constituíam uma multidão habitante de um mesmo lugar. Já Sánchez-Labrador ([1770-1776], v. II:255) notava que essas populações se percebiam como diferentes. Segundo ele, Chané é "un nombre que compreende todas las parcialidades, aunque estas para distinguirse entre si, se aproprian otros nombres”. Portanto, afirmam os antropólogos, é necessário fazer uma distinção entre aquilo que chamam de "colônias" chané e suas "matrizes" - que seriam os "verdadeiros" aldeamentos guaná (Richard e Combès 2015:244).

A formação dessas "multidões", por sua vez, estaria ligada ao processo de colonização do interior chaquenho efetuado pelos Guaná. Segundo Susnik (1972:179), sendo reconhecidos por seus "etos" agricultor, os Guaná tinham uma "tendência à maximização do aproveitamento agrícola”, procurando em outras populações "braços" que pudessem trabalhar em suas roças. Mas, ao contrário dos Eyiguayegui, a “conquista chané no era una 'conquista guerrera', sino una 'conquista' del gentío productivo" (Susnik: 1972:197). Sua intenção ao trazer outras populações para perto de si seria a de maximizar a produção de suas roças, e não a de aumentar seu poderio militar (que Susnik acreditava ser a intenção dos Eyiguayegui). A formação das colônias Guaná seria, portanto, bem diferente do modo eyiguayegui de relação com outros grupos: não havia uma imposição bélica às aldeias diferentes ou rivais, e sim uma atração e organização em aldeias e populações de diversas origens (Richard e Combès: 244). Enquanto a relação entre os Eyiguayegui e os Guaná seria “tributária” (voltarei ao tema na próxima seção), a dos Guaná com suas colônias seria a de

\footnotetext{
${ }^{69}$ No mais, a corrente tradução dos nomes chaquenhos por "escravos" nos mostra que os europeus pareciam ter uma tendência a descrever relações de alteridade como "escravidão”, talvez por sua própria maneira de lidar com o diferente. Vimos acima que os espanhóis se referiam aos povos que não se agregavam a seus fortes como "escravos", tratando como "amigos" apenas os Guarani, que acreditavam ter conquistado. Essa separação é semelhante àquela efetuada pelos colonizadores portugueses, que distinguia “índios aldeados e aliados" e "índios inimigos espalhados pelos 'sertões”, povos a quem se aplicaria o direito de guerra (justa) e cujo destino legal seria a escravidão (Perrone-Moisés 1992: 117).
} 
"dependência socioperiférica"70, em que certas populações não estariam inteiramente subjugadas, mas dependeriam de outras (Richard 2011:223). Assim, os grandes núcleos chaná/guaná do Alto Paraguai estariam exercendo uma ação colonizadora no interior do Chaco, atraindo e reagrupando populações heterogêneas em torno de 'colônias' que dependiam de suas 'matrizes"' (Richard e Combès: 244).

Atrelado ao ímpeto expansionista guaná estaria sua estratificação social, por sinal muito parecida com a dos Eyiguayegui. Segundo Susnik (1972:149-50), sua linhagem nobre era constituída pelos unati, ou capitães. Os wahere-txane, os "comuns", eram os trabalhadores agrícolas, cultivadores e "gente de serviço", e era nessa camada que se "recrutavam" pessoas para ir trabalhar nas tolderias eyiguayegui. O shuna-asheti eram os guerreiros, uma classe mais "ocupacional”, que podia unir tanto nobres quanto comuns e "escravos". Por último, vinha a classe dos kauti, cativos de guerra ${ }^{71}$.

Essas duas evidências etnográficas - o expansionismo e a "estratificação social" guaná - são contra-argumentos indubitáveis àquele "argumento de peso": nos fazem ver complexidades antes apagadas da história da relação Eyiguayegui-Guaná72. Richard e Combès (2015), porém, vão além, entendendo esses dados como prova de que, na realidade, a hierarquia subjacente à relação entre os Eyiguayegui e os Guaná não seria resultado da superioridade militar dos primeiros e sim de uma estrutura préexistente a essa relação: segundo os autores, a hierarquia era, primeiramente, um traço da organização social arawak que teria se estendido aos Eyiguayegui.

Essa "hipótese inversa" (Richard e Combès 2015: 232), como vimos, não é novidade na literatura especializada: Herbert Baldus (1975:24), por exemplo, já havia afirmado que a "força da personalidade cultural" dos Guaná - população que tinha, segundo certas especulações ${ }^{73}$, influências andinas - teria feito os Eyiguayegui adotarem sua estratificação social. Já Alfred Métraux (1946:239) escreve que o fato de cada "vila" guaná ser submetida por um "bando" eyiguayegui fez com que as duas culturas, inicialmente diversas, se tornassem idênticas. De um lado, os Eyiguayegui teriam aprendido com seus "servos" a tecelagem do algodão, as técnicas da cerâmica e do roçado e sua estratificação e, de outro, os Guaná teriam modificado sua estrutura social, adotando cavalos, tornando-se mais guerreiros e adquirindo "escravos".

\footnotetext{
70 A expressão é de Susnik (1978) e foi adotada por Richard (2011) e Richard e Combès (2015).

${ }^{71}$ Roberto Cardoso de Oliveira (1983:35) faz uma apresentação das classes sociais guaná bem parecida. Segundo ele, aquela sociedade era formada pelos naati, "nobres”; os waherê-txané, "comuns”; e os kauti, cativos de guerra.

72 A grande densidade demográfica das aldeias guaná aliada à produção agrícola proveniente dessa concentração de pessoas é também apontada por Santos-Granero, que classifica “os Guaná” não como povos servis, mas como populações tributárias, como discutirei na próxima seção.

${ }^{73}$ Ver Métraux (1946: 211); Baldus (1975: 24); Radin (1948: 211 ).
} 
O pressuposto de que a "estratificação social” (em conjunto com a cerâmica, a tecelagem e a agricultura) é na verdade um "traço cultural” roubado pelos Eyiguayegui dos Guaná fundamenta-se, como afirmado, em uma premissa fundamentalmente evolucionária. Mesmo a denominação das habitações eyiguayegui como tolderias ou bandos, em contraste com as vilas ou aldeamentos guaná mostra uma constante diferenciação assimétrica, em que se considera os "cavaleiros" menos avançados do que os "agricultores". A ênfase no "etos expansionista" guaná - hipótese aventada por Susnik - também vai no mesmo sentido. Tudo se passa como se os povos guaicurú rústicos caçadores-coletores - se contentassem com relações mais imediatas, tecendo relações apenas com seus vizinhos, enquanto os arawak - agricultores de maior visão, mais "evoluídos" - tivessem um plano de unificação pan-chaquenha.

Simplesmente "inverter" a hipótese da dominação baseando-se no “expansionismo" e na "estratificação" guaná, portanto, não parece suficiente. Em primeiro lugar, porque colocar os Eyiguayegui no polo de guerreiros e os Guaná no de agricultores pacíficos não se sustenta. Entre estes últimos havia, assim como entre os primeiros, uma categoria de pessoas guerreiras que gozava de grande prestígio ${ }^{74}$ e, mesmo que não se pudesse visualizar, entre os Guaná, "guerras empíricas visíveis"75, esse fato não seria suficiente para defini-los como pacíficos por natureza. O antropólogo francês Patrick Menget (1985:135) refletiu já há algum tempo, em relação ao Alto Xingu, acerca do erro que cometemos quando aplicamos às sociedades ameríndias certos critérios do que consideramos ser a guerra (constituída por expedições bélicas, uma categoria de pessoas que só se dedica aos ataques, enfim, a parte mais evidente da guerra). A guerra nas Américas está em muitos outros níveis e se expressa de tantas maneiras diversas às nossas (como na feitiçaria ou nas festas, por exemplo) que não podemos classificar seus povos como guerreiros ou pacíficos a priori ${ }^{76}$.

Em segundo lugar, não há como saber se os Guaná tinham planos de colonizar o interior chaquenho. Mas o fato de, ao longo do tempo, os documentos descreverem diferentes povos unindo-se e separando-se faz pensar que eles estavam mesmo relatando blocos constituídos por mecanismos de fusão e fissão, ou "blocos espaçotemporais”, nas palavras de Perrone-Moisés e Sztutman (2010:417). Ou seja, em alguns momentos os Guaná se aliavam aos "Echoaladi" e em outros aos "Zamuco". Da mesma maneira podia acontecer com os Eyiguayegui: quando os espanhóis chegaram ao

\footnotetext{
${ }^{74}$ Cardoso de Oliveira (1983:41-4).

${ }_{75}$ A expressão é de Sztutman (2012: 246).

${ }^{76}$ As diferentes formas de guerra chaquenha e, mais especificamente, eyiguayegui, será discutida no capítulo 3.
} 
Chaco, eles estavam unidos por "relações de vassalagem" (Schmidel [1567]:45) com os Guaná mas, com o passar do tempo, começaram a construir uma relação bem parecida com os Chamacoco. Além de não caberem nas categorias de sociedades guerreiras e pacíficas, portanto, as relações entre Eyiguayegui e Guaná, bem como entre os Guaná e suas "colônias" pareciam ser contextuais, sendo cristalizadas apenas pelas fontes que as descreviam e pela antropologia posterior. O que permanece comum a todas as análises é a relação por elas efetuada entre diferenças nas tarefas ${ }^{77}$ de dois grupos vizinhos e entrelaçados, que da perspectiva europeia apareceu como evidência de "vassalagem" e, consequentemente, fez pensar na relação nobres/servos.

Além de contextuais, essas relações pareciam ter outra característica, à revelia do que afirmam as fontes e diversos antropólogos: elas não se construíam em blocos, ou seja, entre "os Eyiguayegui” e "os Guaná”. Para seguir na tentativa de entender esse “complexo hierárquico”, portanto, é preciso questionar, antes, a própria existência dos tais blocos, um dos principais pressupostos da noção de "servidão”.

\subsubsection{Assimetrias entrelaçadas}

Os maiores indícios da submissão dos Guaná pelos Eyiguayegui apontados nas fontes são as visitas que os oquilidi faziam aos niyolola em determinados períodos do $a^{78}$ e os mutirões de "trabalhadores" guaná que se deslocavam até as tolderias eyiguayegui periodicamente para cultivar suas terras ${ }^{79}$. Demonstro a seguir que essas duas evidências caem por terra quando consideramos os casamentos entre os capitães eyiguayegui e as capitãs guaná. Aliás, todo esse complexo de relações - as visitas, os mutirões e os casamentos - nos mostram também que enxergá-las como um relacionamento entre "mônadas" não parece ser o melhor caminho: se as tomarmos partindo de relações mais localizadas, poderíamos visualizá-las em uma rede de relações ${ }^{80}$ muito mais ampla que aquela do Alto Paraguai, em que os ditos "blocos" eyiguayegui e guaná tampouco aparecem.

\footnotetext{
77 As tarefas serão melhor discutidas no próximo capítulo.

78 As melhores descrições dessas visitas são feitas por Sánchez-Labrador. Ver, por exemplo, Sánchez Labrador ([1770-1776], v. II:23).

${ }^{79}$ Segundo Azara (1809:26), “[e]n la época de la primera llegada de los españoles los guanás acudían [...] a reunirse en tropas con los mbayás para obedecerlos y servirlos y cultivar sus tierras sin ningún salario. De aquí procede que los mbayás los llamen siempre sus esclavos”.

${ }^{80}$ Para uma discussão do interesse teórico-metodológico em considerar redes regionais, evitando a atomização dos grupos evolvidos, ver Gallois (2005).
} 
Sánchez-Labrador ([1770-1776], v. I:267) afirma em seus diários que os Guaná haviam sido conquistados pelos Eyiguayegui não pela coerção, mas pela "unión de sus casamientos”. O jesuíta explica: “[a]lgunos caciques o capitanes Eyiguayeguis se casaron a su modo con cacicas o capitanas Guanás. Los vasallos de estas, muertas ellas, quedaron en un perpetuo feudo a los descendientes de los maridos de sus señoras”. De acordo com o missionário, portanto, a relação de dominação que parecia acontecer entre os Eyiguayegui e os niyolola era na verdade um sistema de "vassalagem" complexo, em que era absolutamente normal que servos - ou melhor, servas - se casassem com seus "senhores", os capitães eyiguayegui, e trouxessem consigo seus próprios "escravos", aqueles da classe dos kauti (cativos).

Foi a partir desse relato do missionário que alguns antropólogos defenderam a hipótese de que os Guaná teriam “transmitido” sua estratificação para os Eyiguayegui. Essa tentativa de encontrar a origem da hierarquia, porém, não parece produtiva precisamos saber, antes, se ela realmente existe. O fato a ser considerado é que, assim que os europeus aportaram no Chaco, eles observaram duas "nações" que compartilhavam uma mesma matriz relacional operante em todos os níveis, do que chamaríamos "intra-aldeão" ao regional; em cada um desses níveis havia diferenciações que constituíam grupos diferentes. No primeiro, havia as distinções entre niniotagi e nibotagi (no caso eyiguayegui) e entre unati e kauti (no caso guaná). No segundo, havia as diferenças entre "os Eyiguayegui” e os "os Guaná”. O caso é que, em nenhum desses níveis, essas diferenças eram cristalizadas: assim como os etnônimos, elas existiam (e ainda existem) apenas em relação ao outro, que era definido contextualmente. Todas as descrições sobre as relações entre índios eyiguayegui e guaná parecem se fundamentar nessa projeção: desde os nomes dos grupos até sua existência como grandes blocos, todos esses elementos são resultado de uma leitura do Chaco feita por meio de um “ideário nacionalista”.

Aliado a esse compartilhamento do que chamei de "matriz relacional" havia o fato de que os niniotagi (os "nobres" eyiguayegui) se casavam com as unati (as "nobres" guaná). Quando as capitãs guaná se casavam, elas se mudavam para as tolderias de seus maridos, trazendo consigo seus kauti, cativos de guerra. Aí se explica a quantidade relativamente grande de "guanás" 81 nas tolderias eyiguayegui: eles se mudavam junto com suas "senhoras". Justifica-se também os "mutirões" de wahere-txané - a parte dos "trabalhadores” guaná - que vinham cultivar as roças eyiguayegui: tudo indica que os

${ }^{81}$ Vimos que as fontes tendem a colocar sobre esse etnônimo-guarda-chuva uma grande diversidade de pessoas que muitas vezes não falavam a língua arawak e nem mesmo se consideravam guaná. 
Guaná tinham uma divisão de atribuições muito parecida com a dos Eyiguayegui, em que a parte dos capitães não devia cultivar a terra ${ }^{82}$. Esses mutirões de wahere-txané vinham, portanto, realizar serviços que não deveriam ser feitos pelos "senhores". Por último, explica-se também as visitas realizadas pelos "senhores" eyiguayegui às vilas guaná: eles iam visitar as famílias de suas esposas.

Nessas ocasiões, de acordo com Sánchez-Labrador, os "senhores" se hospedavam nas aldeias de seus "servos" e recebiam homenagens, produtos agrícolas como arroz, mel, frutos e raízes, milho e abóboras, grãos e urucum, além de mantas de algodão tecidas pelas capitãs guaná. Em troca, os nobres eyiguayegui davam "aos Guaná" tudo que lhes era solicitado, em especial bens obtidos através do contato com não-índios, como facas, lâminas de ferro, agulhas, pinças e anzóis ${ }^{83}$.

O vocabulário utilizado pelo missionário - "servos" e "senhores", além dos etnônimos de "nações" inteiras - muda totalmente o cenário dessas visitas. Descritas por meio desse aparato vocabular, esses eventos parecem mesmo um indício da sujeição de um pelo outro, ainda que o relato nos mostre uma situação de troca - de um tipo bastante frequente, aliás, nas festas ameríndias. Somos levados a enxergar essa relação como resultado de um contrato de vassalagem em que os poderosos nobres ao mesmo tempo ameaçavam e ofereciam proteção aos agricultores, recebendo em troca os frutos da terra por eles cultivada. A interpretação de Santos-Granero (2009: 83) sobre as relações constituintes do "complexo hierárquico" é bem parecida com essa (ainda que não as aproxime da vassalagem europeia): o autor afirma que “os Guaná” podiam ser entendidos como populações tributárias porque, ainda que os capitães eyiguayegui se casassem com as donas guaná, essa relação estava sempre permeada pela guerra. Segundo o antropólogo, a "hostilidade crônica" era a maneira encontrada pelos Eyiguayegui para trazer os Guaná, que eram mais numerosos porém “mais fracos", para uma relação tributária. Por meio de um viés no poder e na coerção, portanto, os produtos agrícolas entregues pelos Guaná são vistos como tributos e "os Guaná” como "populações tributárias”.

A comparação com as relações de vassalagem se complica quando percorremos a extensa lista dos bens manufaturados que os Eyiguayegui davam a seus "servos" em troca dos produtos agrícolas. Aliado a isso está também o fato de que os nobres pareciam ser totalmente espoliados quando voltavam das vilas arawak, ficando sem praticamente nada. Segundo Sánchez-Labrador ([1770-1776], v. II:23), os capitães

\footnotetext{
${ }^{82}$ As atribuições eyiguayegui são tema do capítulo 2.

${ }^{83}$ Sánchez-Labrador ([1770-1776], v. II:23); Richard e Combès (2015:240).
} 
saíam das vilas guaná "ricos y contentos com sus bollos de nibadena [urucum]” e ao voltar para suas esteiras, davam quase tudo o que tinham recebido:

En la primera jornada, al parar poco después de mediodía, cada capitán hace alarde de sus riquezas. Después reparte mantas y color a los de su capitanía; pero es tan poco, que o no les alcanza, o en tan corta cantidad, que quedan poco menos surtidos que a la ida. Así sus viajes a las tierras de los Niyololas les acarrean gran molestia y utilidad casi ninguna.

Nesse sentido, a relação em questão não pode ser reduzida à "economia”, como acontece com a vassalagem na Europa feudal. O próprio "esbanjamento" dos chefes parece ser, inclusive, próprio dos encontros festivos entre os índios, que extrapolam em muito o plano "econômico" (Perrone-Moisés 2015). Por fim, é necessário lembrar que, na realidade, as visitas tratavam-se de eventos que envolviam famílias, tolderias ou até vilas - nunca "os Eyiguayegui” e "os Guaná”.

Segundo Robert Lowie (1948: 348), um fato "curioso" sobre a relação "Eyiguayegui-Guaná” era o de que "os Guaná nunca se viram como inferiores aos Mbayá comuns, mas apenas aos chefes”. Essa afirmação, aliada às descrições de Sánchez-Labrador, parece ser mais uma evidência de que não havia, no Alto Paraguai, uma hierarquia entre dois blocos impermeáveis. Sugiro que os dados trazidos pelas fontes acerca dos casamentos eyiguayegui-guaná sejam lidos como evidência de que as "partes" dos "nobres" (niniotagi e unati) e dos "comuns" de cada grupo (eyiguayegui ou guaná, contextualmente definidos) formavam algo como "metades exogâmicas" que precisavam casar fora, mas com pessoas “do mesmo nível”. Mesmo Susnik (1972: 86) parece trazer essa ideia, quando afirma que os "comuns" eyiguayegui tinham o "costume de casar com as mulheres de origem chané, ainda que mantivessem certa distância dos nibotagi” - eles preferiam contrair matrimônio com pessoas de fora (os "comuns" guaná) a se casar com "membros" de outra "camada".

É importante lembrar que essa hipótese já foi levantada por Roberto Cardoso de Oliveira (1983:48) sobre os Terena. Segundo o antropólogo, os unati terena, por conta da restrição de seu mercado matrimonial causada por sua nobreza, precisavam procurar esposas em outros aldeamentos e se casar com capitãs de outras localidades. De acordo com ele, a existência da "sociedade terena" só se fazia possível com esse movimento ao exterior realizado pelos capitães, uma vez que os nobres não podiam se restringir a seus aldeamentos se quisessem casar e ter filhos. Não é preciso dizer que o mesmo parecia acontecer entre os "índios cavaleiros": os "senhores" eyiguayegui, para não se casarem com pessoas de outros "níveis" acabavam procurando nobres de outras 
tolderias ou vilas, como as dos índios guaná ${ }^{84}$. Interessante notar que essa hipótese acaba por dialogar com a reflexão feita por Lévi-Strauss (1996: 208), que se perguntava se era possível a sobrevivência da sociedade kadiwéu mesmo que seus nobres se preocupassem tanto com as aparências, em "não perder a dignidade e, sobretudo, não contrair um casamento com gente inferior". Ao que parece, a "assimetria desvairada" 85 eyiguayegui, que foi entendida pelo francês como uma ameaça, se entrelaçava às assimetrias guaná e tornava a existência desses grupos possível exatamente porque os colocava em relação.

Em suma, vistas do ângulo dos casamentos, e não da dominação e coerção, as visitas trazem outro problema à suposta hierarquia desse sistema, nos fazendo ver também quão complicado é falar em relações entre "os Guaná” e "os Eyiguayegui" como duas totalidades. As assimetrias encontradas pelos autores das fontes pareciam ser mais localizadas, entre famílias ou entre pessoas que tinham um trânsito entre tolderias guaicurú e vilas arawak. Longe de restringir essas relações a pequenos espaços, como se poderia objetar, essa constatação permite pensar essa matriz relacional funcionando em diversos contextos. O que os exploradores, viajantes e missionários estavam observando fazia parte de uma rede muito maior de relações, ainda que seu pequeno alcance devido à sua colocação às margens do Chaco não lhes permitisse ter senão uma visão muito limitada, além de claramente enviesada.

Pois não eram apenas grupos "guaná” que os capitães eyiguayegui visitavam: eles também iam ao encontro, rotineiramente, de outras tolderias e parcialidades, bem como outras populações, como grupos guarani e chiquito. Elas pareciam, enfim, ser uma etiqueta presente em todo o Chaco. Nem mesmo os europeus escaparam a essa lógica. As visitas a seus fortes eram muito similares: Cabeza de Vaca descreve que, certo dia, cerca de 20 homens guaicuru postaram-se "ante o governador" e se apresentaram como "os principais de sua nação de guaicurus”, dizendo

que eles e todos os seus antepassados haviam tido guerras frequentes com todas as nações daquelas terras [...]. Sempre haviam vencido e maltratado os derrotados, nunca aparecendo quem os derrotasse. Mas que agora, finalmente, haviam encontrado quem era mais forte do que eles, e assim vinham se entregar como escravos, para servir aos espanhóis. (Cabeza de Vaca [1555]:163).

\footnotetext{
${ }^{84}$ Não custa lembrar que na América o status de "nobre" ou "comum" sempre tem de ser feito e refeito em corpo e comportamento; nunca é dado uma vez por todas por uma mera questão de genealogia. Voltarei a essa questão nos próximos capítulos.

${ }^{85}$ Lévi-Strauss utiliza a expressão em seu artigo sobre as arte da Ásia e da America (ver Lévi-Strauss 2012: 347-387).
} 
A esse "acordo de paz", como o interpreta Cabeza de Vaca, se seguiram algumas visitas em que alguns índios denominados por ele "guaicurús" levavam "carne de veado, de porco montanhês assada e grelhada, pescado, couros de "tigre", anta e veado e mantas e trocavam por "milho, mandioca, arco, flechas" dos índios aldeados ao redor dos Forte Assunção, definido como “os Guarani” pelo explorador. Nessas visitas aos fortes europeus, grupos de eyiguayegui também conseguiam objetos como facas, garfos, contas de vidro e agulhas, que eles trocavam com guanás e outras populações chaquenhas por objetos como "[ $[\ldots]$ mantas, plumas de varios colores, tabacos, cañas para flechas y víveres" (Sánchez-Labrador [1770-1776], v. I:64). As trocas realizadas com estes povos de língua arawak, portanto, não eram as únicas e pareciam ser uma maneira de estabelecer relações com os estrangeiros, fossem eles índios ou não.

Não por acaso o Gran Chaco foi qualificado por Carvalho (1992) como "encruzilhada de povos", local em que diversos povos se encontravam e se "misturavam". A mesma autora utiliza a expressão corredor de povos (1992: 458) para descrever a mobilidade das populações da região. Spensy Pimentel (2012:62), na mesma direção, chama atenção para a existência de um intenso comércio de metais entre os povos andinos, a oeste, e os povos guarani, a leste. Esse comércio movimentava toda o Chaco e o Alto Paraguai, intensificando a mobilidade de suas populações, imersas em um contexto de intenso intercâmbio, em que os índios que se auto-denominavam Eyiguayegui tinham um papel ativo. $\mathrm{O}$ fato de esses índios participarem da "grande cadeia de troca de metal andino" (Richard e Combès 2015:233), estendendo relações comerciais até a Bolívia deixa também em aberto a possibilidade de que suas visitas e relações matrimoniais não estivessem restritas ao Alto Paraguai. Mais do que pensar em dois blocos se relacionando por um certo recorte espaço-temporal, portanto, devemos ter em mente essa cadeia de relações Chaco adentro, entrelaçando guanás, eyiguayeguis, guaranis, e mais além.

Falar na subjugação de uma totalidade social por outra, assim, é não levar em consideração aquilo que Richard (2011:219) entende como a especificidade da região chaquenha, ou seja, a “[ [...] maleabilidade de suas formações sociais, a extrema rapidez dos processos de recomposição e rearranjo étnico" e a grande facilidade "com a qual os povos de línguas e de horizontes diferentes se misturam, se decompõem e se recompõem" em períodos relativamente breves ${ }^{86}$.

\footnotetext{
${ }^{86}$ Note-se que essa parece ser uma característica ameríndia mais do que chaquenha (ver, por exemplo,
} Perrone-Moisés 2006; Perrone-Moisés e Sztutman 2010). 
Em cada local e momento dado, é certamente possível encontrar no Chaco grupos que se autodenominam Eyiguayegui ou Terena, Layana e Kinikinau, por exemplo, e sempre relacionados uns aos outros por suas diferenças (porque assim se concebem relações na América indígena). Mas nem os grupos nem as relações entre eles são fixos. Aplica-se ao Chaco, como ao resto da América (a julgar pelas evidências e contando com as análises de Lévi-Strauss) o retrato feito por Viveiros de Castro (2002: 220) de sociedades que pareciam não existir fora "de uma relação imanente com a alteridade. [...] Tratava-se, em suma, de uma ordem onde o interior e a identidade estavam hierarquicamente subordinados à exterioridade e à diferença, onde o devir e a relação prevaleciam sobre o ser e a substância”.

Por fim, é necessário pontuar que a "mistura" à qual Richard se refere não deve ser confundida com a ideia de "simbiose" aventada por Alfred Métraux (1946:239) que, segundo o suíço-argentino, estaria ligada ao suposto processo de assemelhamento entre Guaná e Eyiguayegui citado acima. Basilar na caracterização do “complexo hierárquico” Eyiguayegui - Guaná, tal como definido por Combès, Lowrey e Villar (2009: 73), o conceito é tema da próxima seção.

\subsubsection{Simbiose}

Utilizada por muitos antropólogos de modo a suavizar as descrições da "dominação" de uns pelos outros, que - desde os tempos coloniais - nunca foi irrevogável, a noção de simbiose tem origem nos estudos de botânica. Trazido à baila em 1878 pelo botânico alemão Heinrich Anton de Bary, o conceito se refere, em poucas palavras, à "vida conjunta de organismos diferentes" 87 . Em seu estudo sobre a associação entre fungos e algas, de Bary percebeu que este convívio interespecífico acabava constituindo uma terceira espécie: a dos líquens. Uma terceira unidade, portanto, seria formada a partir da agregação de dois organismos inicialmente separados. Posteriormente, essas relações entre organismos foram divididas pela botânica entre aquelas harmônicas (que não prejudicam nenhum dos dois indivíduos) e as desarmônicas (que causam danos a pelo menos um dos organismos envolvidos) ${ }^{88}$.

Obviamente, o uso antropológico do conceito não está plasmado a seu significado na botânica, mas parece levar consigo três de suas características. Primeiramente, a noção de interdependência entre "espécies" diferentes. No caso dos estudos sobre o Chaco, como demonstrado, parecia-se entender as sociedades

${ }^{87}$ Oulhen, Schulz e Carrier (2016: 135); Lopes (199:552).

${ }^{88}$ Lopes (1999:551-2). 
envolvidas na relação de simbiose - constituídas ora por caçadores-coletores guerreiros, ora por agricultores pacíficos - como entidades fundamentalmente distintas que, com o passar do tempo, acabaram se fundindo e formando uma só sociedade hierarquizada. Segundo, a ideia de que dois "organismos" se beneficiam da relação de complementaridade que define a simbiose. Baldus (1975:24), por exemplo, afirma ter existido entre as duas populações uma "simbiose com vantagens mútuas" 89 . Por fim, a unidade resultante da simbiose entre dois organismos.

A primeira característica emprestada do conceito botânico pela antropologia já foi amplamente discutida: sabemos que essa diferenciação das populações em "espécies" diferentes não se aplica, pelo menos nos termos até agora apresentados. A complementaridade entre duas "nações" - conceito também já discutido -, definidora da simbiose, por sua vez, merece uma reflexão pormenorizada.

Como afirmado anteriormente, a noção de simbiose aparece na literatura muitas vezes de modo a abrandar a de hierarquia. Segundo essa visão, Eyiguayegui e Guaná estavam ligados por uma relação de hierarquia, porém estavam também conectados por uma simbiose que os fazia viver de forma praticamente harmônica, casando-se entre si, visitando-se amigavelmente, trocando seus produtos... A "hierarquia" parece ser, aos poucos, colocada em um plano subjetivo, mais formal: as diferenciações entre niniotageleudi, niniotagilionigi, uneleiguá, nibotagi e niyolola, bem como aquelas entre unati, wahere-txané, shuna-asheti e kauti operariam apenas no nível do discurso. A simbiose, por sua vez, estaria no plano do vivido.

Esse "estatuto ontológico" dos dois conceitos é também alvo de críticas do antropólogo Eduardo Viveiros de Castro (1983:255) em sua resenha dedicada ao livro de Alcida Ramos, Hierarquia e simbiose (1980), que pretende discutir três casos em que essas duas formas de relação se conjugam: Sanumá/Maiongong (Roraima), Makú/Tukano (noroeste amazônico) e Guarani/Kaingang (Paraná). Segundo o autor, o modo como esses dois conceitos são articulados pela autora (de maneira muito parecida com o que acontece na literatura chaquenha) faz com que a hierarquia seja tomada como “fenômeno no ‘plano ideológico’ (i.e. das representações), e a simbiose como seu equivalente que o nega parcialmente no "plano do comportamento"” (Viveiros de Castro 1983:255-6). Nas obras de Métraux e Baldus, a assimetria entre "senhores"

89 Como é o caso do mutualismo e da protocooperação. No primeiro caso os dois indivíduos da relação mantêm relações de dependência, enquanto no segundo apenas um deles se beneficia, enquanto o outro não sofre nenhum prejuízo (Lopes 1999: 552). Se fôssemos mais a fundo e quiséssemos classificar o tipo de simbiose encontrada no Chaco, a identificaríamos como mutualismo, levando em consideração a suposta interdependência entre "os Guaná” e "os Eyiguayegui”. 
eyiguayegui e os "escravos" de suas esposas, de forma parecida com a interpretação de Ramos, parecem ser apenas subjetivas, como se essas distinções não operassem na "vida real”. Essa forma de explicar os movimentos contra-hierárquicos chaquenhos, posicionando a suposta hierarquia desses sistemas em um plano subjetivo, não resolvem, porém, as contradições desse modelo analítico: a hierarquia continua a parecer furada, mas agora com menos importância, já que existiria apenas no plano das ideias.

No livro de Alcida Ramos a ênfase na complementaridade tem também o objetivo de contrastar as relações intertribais (entre populações indígenas) daquelas interétnicas" (entre índios e "brancos"). Segundo Ramos - que considera a relação Eyiguayegui-Guaná um exemplo da convivência entre simbiose e hierarquia -, sua intenção é a de

$$
\begin{aligned}
& \text { mostrar como sociedades tribais em conjunção, que apresentam } \\
& \text { relações de desigualdade entre si, desenvolveram um tipo de } \\
& \text { interação tal, que permite a coexistência de dois ou mais grupos, sem } \\
& \text { que haja a tentativa de eliminação de um grupo, considerado inferior, } \\
& \text { pelo outro, tido como superior [como seria o caso das relações } \\
& \text { interétnicas] (Ramos 1980:5). }
\end{aligned}
$$

A especificidade dessas formações simbióticas e hierárquicas seria sua contraposição àquelas entre as sociedades indígenas e a "sociedade nacional” (Ramos 1980:5). Roberto Cardoso de Oliveira (1980: xi), em prefácio ao livro de Ramos, explica que enquanto a hierarquia entre povos indígenas se refere a relações de status, mais brandas, as relações entre índios e não-índios remetem a relações de classe, mais violentas. Assim, a existência de uma "relação simbiótica" entre, por exemplo, os Eyiguayegui e os Guaná, possibilitaria relações complementares - "sem assumir a forma rígida de castas" - enquanto a "estrutura contraditória" que tem lugar na relação índios e "brancos" só poderia trazer a desigualdade mais profunda e a "dominação política”.

Não posso deixar de comentar que, de saída, a simbiose e a hierarquia indígenas são definidas na obra a partir das relações com a "sociedade nacional" (Viveiros de Castro 1983: 254). Quando se trata das relações chaquenhas, porém, as possibilidades de divisão entre as relações entre diferentes povos indígenas e entre índios e não-índios são mais complicadas. Como demonstrado, os europeus entraram em círculos de trocas, de visitas e de guerras pré-existentes à sua chegada, sendo tratados como um novo

\footnotetext{
90 Definida por Cardoso de Oliveira (1972:85-129 apud Ramos 1980: 5) como aquelas em que "o índio enfrent [a] as pressões de outra sociedade, avassaladoramente mais poderosa tecnológica e politicamente que a sua”.
} 
inimigo/aliado. No mais, é no mínimo complicado instituir tamanho abismo entre povos indígenas e a genérica "sociedade nacional" em toda a América, onde as "condições de vida" de seus povos, "suas formas de organização e suas representações de si encontravam-se todas conectadas à 'exterioridade', fossem elas constituídas a partir das alteridades dos 'brancos', dos inimigos, etc” (Gallois 2005:8).

O importante a salientar é que a ideia de simbiose surge como uma tentativa de focar a "complementaridade" e a facilidade na resolução dos conflitos dessas relações interlocais. Aliado a ela estaria o conceito de hierarquia, que se referiria mais aos status, distintivos de pessoas que, no plano material, não seriam tão diferentes assim. Simbiose desponta, enfim, como uma maneira de suavizar o complexo conceito de hierarquia. Complexo porque ele tem que comportar em si o seu contrário: o casamento entre "nobres" e "servos", o comércio e a festa entre eles.

Nesse sentido, tanto Métraux quanto Baldus e Ramos tecem seus argumentos de modo a dar a entender que duas sociedades - essencialmente diferentes entre si - se juntaram em relações harmônicas permeadas, porém, por status hierárquicos. Longe de resolver as contradições colocadas pela utilização do conceito de hierarquia para descrever essas relações, entretanto, a adição da noção de simbiose parece apenas multiplicá-las, separando indevidamente alguns aspectos dessas relações em subjetivos e materiais. A partir da leitura de Baldus, Robert Lowie (1948: 349) chega a solapar a ideia de hierarquia nesse caso, considerando a ideia de simbiose - entendida como fundamentada principalmente na troca - muito mais aplicável à relação EyiguayeguiGuaná. A troca, como vimos, estava mesmo presente nesse caso, mas as assimetrias ali presentes não podem ser deixadas de lado, nem colocadas em um nível apenas subjetivo. Permitindo que esses movimentos aconteçam, a simbiose acabou por adicionar mais uma dose de contradição a essas relações.

Além disso, a noção de simbiose atrelada à ideia de troca acaba por trazer (de novo) a discussão para um campo "econômico": acredita-se que ambos os "organismos" envolvidos na relação têm "vantagens mútuas". "Os Guaná” se beneficiariam com a proteção dos guerreiros e "os Eyiguayegui” com a comida ofertada por seus parceiros. Discutirei no próximo capítulo as dificuldades de enxergar as assimetrias chaquenhas como fundamentadas naquilo que chamamos de "economia". Por ora, basta afirmar que essas assimetrias entrelaçadas não pareciam ter em vista nenhuma vantagem visando algum acúmulo: o que estava em jogo era o relacionar-se com o outro.

No mais, partindo da ideia da relação entre diferentes, a noção de simbiose acaba por criar a ideia de que esses diferentes, no fim, se tornarão um, englobados por uma 
mesma relação: a de hierarquia. Essa unidade final - tanto demográfica quanto cultural -, porém, nunca foi alcançada. Aliás, vimos que não havia nem uma "unidade inicial": os grupos que se relacionavam formando o que hoje se chama "complexo hierárquico" existiam apenas contextualmente, não formando "nações" em nenhum nível.

Não podemos nem mesmo afirmar que as relações denominadas "hierárquicas" englobavam todas as relações entre pessoas eyiguayegui e guaná: quando olhamos esse complexo a partir de diferentes ângulos, o enxergamos de modos muito diversos. Vimos que os "servos" Guaná, por exemplo, se aproveitavam muito bem da relação com os Eyiguayegui, espoliando-os em suas visitas e muitas vezes "usando-os" como intermediários nas negociações com os europeus. Essa posição de "intermediários" dos Eyiguayegui é uma das evidências que faz Richard e Combès (2015: 241) "inverter" a hipótese de dominação dos Guaná pelos índios de língua Guaicurú, afirmando que “o sistema de hierarquias mbayá é uma prolongação da sociologia chaná”. Essa mesma posição de intermediários, porém, é muitas vezes vista, em outros contextos etnográficos, como uma evidência do privilégio dessas populações habitantes de regiões de confluência, que tinham fácil acesso a diferentes populações indígenas e nãoindígenas ${ }^{91}$. Dependendo da perspectiva, portanto, a posição de intermediários dos Eyiguayegui pode ser vista tanto positiva quanto negativamente, assim como o lugar dos Guaná, que pode ser lido como sinal de sujeição ou dominação.

A própria definição das relações inter-regionais dos Guaná feita por Susnik (1972:201) já traz consigo elementos contra-hierárquicos. De acordo com a antropóloga, elas geralmente obedeciam a três padrões: a) se impunham sobre populações agrícolas menores, colonizando-as e integrando-as como braços na agricultura; b) firmavam amizade com populações que pudessem oferecer alguma vantagem e trocas; c) com populações belicosas e agressivas, não ofereciam resistência guerreira, e sim se "sujeitavam" como niyolola, criando uma situação de reciprocidade sociopolítica.

O primeiro padrão apontado pela eslovena é relacionado à sua hipótese do colonialismo guaná, já discutido, e a segunda parece ser a descrição de trocas regulares com populações vizinhas. O terceiro padrão, que mais nos interessa aqui, acaba por sugerir que a "sujeição" guaná fazia parte de uma estratégia prévia à relação com os Eyiguayegui. A "servidão voluntária” à qual me referi acima, portanto, parecia mesmo encontrar lugar em terrenos chaquenhos, não por conta da “índole” pacífica dos Guaná (hipótese aventada nas fontes históricas), mas por um artifício dessas populações. Ao

\footnotetext{
${ }^{91}$ Sobre esse privilégio dos grandes anfitriões regionais, ver Perrone-Moisés (2015: 85-6).
} 
levar a sério a voluntariedade dessa "servidão", torna-se possível enxergar o "serviçalismo" característico dessa relação como fruto da vontade dos Guaná e não de sua submissão forçada.

Esse tipo de leitura de relações à primeira vista hierárquicas não é novo nos estudos sobre os povos ameríndios. Ao escrever sobre os Paumari, povo de língua arawá habitante do médio Purus e geralmente descrito como "pacífico" e "inofensivo", Oiara Bonilla (2005: 42) demonstra uma maneira pouco usual de entender as relações entre esses índios e seus "patrões" (regionais que os empregam em diversos serviços). Segundo a autora, os Paumari não apenas não fogem desse tipo de relação como as procuram. De acordo com seus interlocutores, ser empregado garante o acesso a bens e aos cuidados do patrão, que lhes é oferecido em troca dos serviços. "Estar servindo alguém’ é então estar sob sua proteção e ser alimentado direta ou indiretamente por ele"92 (Bonilla 2005: 48). Não é apenas aos empregados que essa relação rende trabalho, portanto: segundo a autora, o empregador tem que ter astúcia e capacidade de sedução através do domínio de técnicas corporais e verbais (Bonilla 2005: 55).

A procura pelo cuidado dos patrões faz com que os Paumari busquem esse tipo de relação, transformando predadores potenciais (ou seja, possíveis empregadores fazendeiros ou pescadores) em patrões. Longe de ser entendida como sujeição forçada, esse processo é percebido pelos Paumari como

[...] a pacificação dos estrangeiros vistos como potencialmente perigosos e vorazes. Ou seja, a autocolocação dos Paumari em uma posição de presa domesticável obriga o estrangeiro a adotar a posição correspondente de pacificador domesticador (ou familiarizador), o que permitiria afastar o perigo da predação e da devoração, mas também controlar a predação potencial pelos próprios Paumari (2005: 58)93.

Sua "capacidade de submissão" e de servir a seus patrões é, portanto, uma "arma” dos Paumari, que obrigariam "qualquer interlocutor em posição de dominação a apiedar-se deles" (Bonilla 2005:59). A submissão nesse caso torna-se uma forma de manter os perigos dos potenciais patrões sob controle.

As relações entre os Guaná e os Eyiguayegui poderiam ser lidas de maneira parecida: a proteção oferecida pelos cavaleiros eyiguayegui em troca dos produtos agrícolas pode ser uma maneira de "cuidado" buscada pelos Guaná. Aliás, talvez não tenham sido os Eyiguayegui os primeiros a se interessarem por essa relação. Os dados

\footnotetext{
92 Algo semelhante acontece entre os Qom do Chaco argentino. Segundo Tola (2012 :121) há, entre alguns qom, uma busca pelo "cuidado" dos brancos, que se procura conseguir por meio do sentimento de compaixão. A afirmação de que são extremamente pobres, continuamente reiterada por eles, por exemplo, é uma tentativa de obter a generosidade de algumas pessoas.

93 O vocabulário aqui utilizado por Bonilla, como "familizarização,, "domesticação" e "predação", se referem às teorias de predação e familiarização de Fausto (2002) e Vilaça (2002).
} 
trazidos pelas fontes não são suficientes para negar esse tipo de leitura, ainda que não sejam o bastante também para confirmá-lo. O caso é que mesmo os cronistas, que definiam esse complexo de relações como "vassalagem”, não podiam negar os benefícios que alguns aldeamentos Guaná tinham na manutenção do relacionamento com certos capitães Eyiguayegui, tanto que, quando o cerco colonial começou a efetivamente enclausurar os Eyiguayegui a uma só área, os Guaná afastaram-se de seus "senhores”, entabulando relações diretas com os não-índios. Essa afirmação, ainda que não explique profundamente o caráter dessas relações, é suficiente para que nos afastemos de interpretações fundamentadas na ideia de hierarquia: pensar esse "complexo" como sujeito a uma única "regra” é extremamente delicado porque no Chaco - assim como nos outros "mundos ameríndios" - é "impossível que uma só perspectiva englobe as outras" (Guerreiro Jr. 2012:119). Tornar-se um, como sabemos, não é o destino ideal nas Américas (Clastres 2003; Lévi-Strauss 1993).

\subsection{Novas alianças, novas guerras}

A época em que ocorreu a denominada "crise da relação Mbayá-Chané" 94 é definida pela literatura especializada como a segunda metade do século XVIII, quando muitas parcialidades eyiguayegui são descritas do lado oriental do Rio Paraguai, próximas ao rio Aquidaban ${ }^{95}$. Nesse período, os Eyiguayegui passaram tanto por seu "apogeu étnico" 96 quanto pelo início de sua sedentarização forçada pelos europeus. Sobre o começo desse período, Susnik (1971:62) escreve:

En la segunda década del siglo XVIII, los Mbayáes alcanzaron una maximilidad 'territorial', de asientos 'económicos' y de zonas incursionistas; el etos guerrero-adquisitivo hallábase estimulado por la continuidad fácil del botín; intensificaron los Mbayáes sus incursiones en todas las direcciones, hacia la provincia de Chiquitos, hacia Mattogrosso y hacia la Cordillera al sur del R. Jejuí; buscaban cautivos en el Chaco y entre los Chiquitos, buscaban metal en cercanías de Cuyabá y buscaban caballar y ganado en las poblaciones coloniais $[\ldots]$.

Foi também nessa época em que os Eyiguayegui entravam recorrentemente em contato com os bandeirantes, por vezes trocando cativos por bens manufaturados, por

\footnotetext{
94 A expressão é de Richard e Combès (2015: 247).

${ }^{95}$ Herberts (1998: 77).

${ }^{96}$ Herberts (2011:36).
} 
outras investindo em sua aliança com os Payaguá ${ }^{97}$ (índios canoeiros que tinham o domínio do Rio Paraguai) para derrotá-los. No final do XVIII, porém, sua aliança com os Payaguá se desfez, povos como os Lengua e os Enimagá começaram a disputar suas terras e os espanhóis passaram a atacar as tolderias de forma muito mais sistemática: as expedições punitivas do governador geral Rafael de La Moneda passaram a surtir o efeito esperado pelos europeus e os Eyiguayegui começaram a se concentrar na região em que hoje está sua Terra Indígena, em território brasileiro ${ }^{98}$. Em resposta aos espanhóis, cuja proposta de relacionamento era o da escravidão a todos os povos do interior, os Eyiguayegui se uniram aos portugueses em diversos contextos, aproveitando-se da oportunidade da troca com os militares ${ }^{99}$. Em suas visitas aos fortes lusitanos eles faziam aliados na luta contra grupos guarani e espanhóis, realizando, num mesmo ato de amizade, a atualização daquela hostilidade histórica e a recusa do modelo de relação proposto pelos espanhóis. Estes últimos, aliás, nunca haviam se acertado com os povos Guaicurú: segundo Susnik (1971:33), os espanhóis teriam quebrado, por diversas vezes, certas regras de hospitalidade de seus capitães. Não era apenas contra alguns grupos guarani que os "índios cavaleiros" - como os MbayáGuaicurú passaram a ser denominados pelos europeus - estavam lutando, portanto: os espanhóis eram também seus inimigos desde o momento de suas primeiras interações.

Longe de divergir dos primeiros colonizadores do Chaco em seus planos de pacificação forçada dos povos chaquenhos, os portugueses souberam se aproveitar da “amizade” com os Mbayá-Guaicurú e conseguiram finalmente penetrar no território chaquenho. O fim do século XVIII e o início do XIX foram marcados pela construção dos Fortes de Nova Coimbra, Albuquerque e Mondego, que garantiram a presença do exército lusitano em terras antes inexploradas pelos europeus e o consequente aumento da pressão pelo aldeamento dos povos nativos ${ }^{100}$. Os relatórios feitos pelos comandantes da Coroa Portuguesa - como Francisco Rodrigues do Prado (1795), Ricardo Franco de Almeida Serra $(1844 ; 1845 ; 1850)$ e Luiz D’Albuquerque Cáceres (1865) aqui citados - enviados às terras eyiguayegui para verificar as possibilidades de aldeamento daqueles povos foram escritos nessa época. Para os portugueses, “[e]stava na ordem do dia $[\ldots]$ ocupar efetivamente as regiões em litígio com os espanhóis para,

\footnotetext{
${ }^{97}$ Os Payaguá (ou Agaces), assim como os Mbayá, eram falantes de língua Guaicurú e reconhecidamente belicosos. Essas semelhanças os fizeram ser descritos como um único povo - Guaicurú - por muitas crônicas, que posteriormente passaram a dividi-los entre povos canoeiros e cavaleiros.

${ }^{98}$ Herberts (1998: 36); Susnik (1971: 67); Santos-Granero (2009: 41).

99 Os Eyiguayegui trocavam com os portugueses carnes de caça, couros de "tigre", anta e veado por produtos europeus como facões, agulhas e espelhos (Herberts 2011:25).

${ }^{100}$ Herberts (2011:30).
} 
assim, garanti-las", de modo que os povos indígenas da região começaram a ser vistos como “[ [...] povoadores das regiões de fronteira, além de uma promissora reserva de mão de obra" (Rodrigues 2009: 12).

\section{Mapa 2 - Localização aproximada das habitações chaquenhas no fim do século XIX}

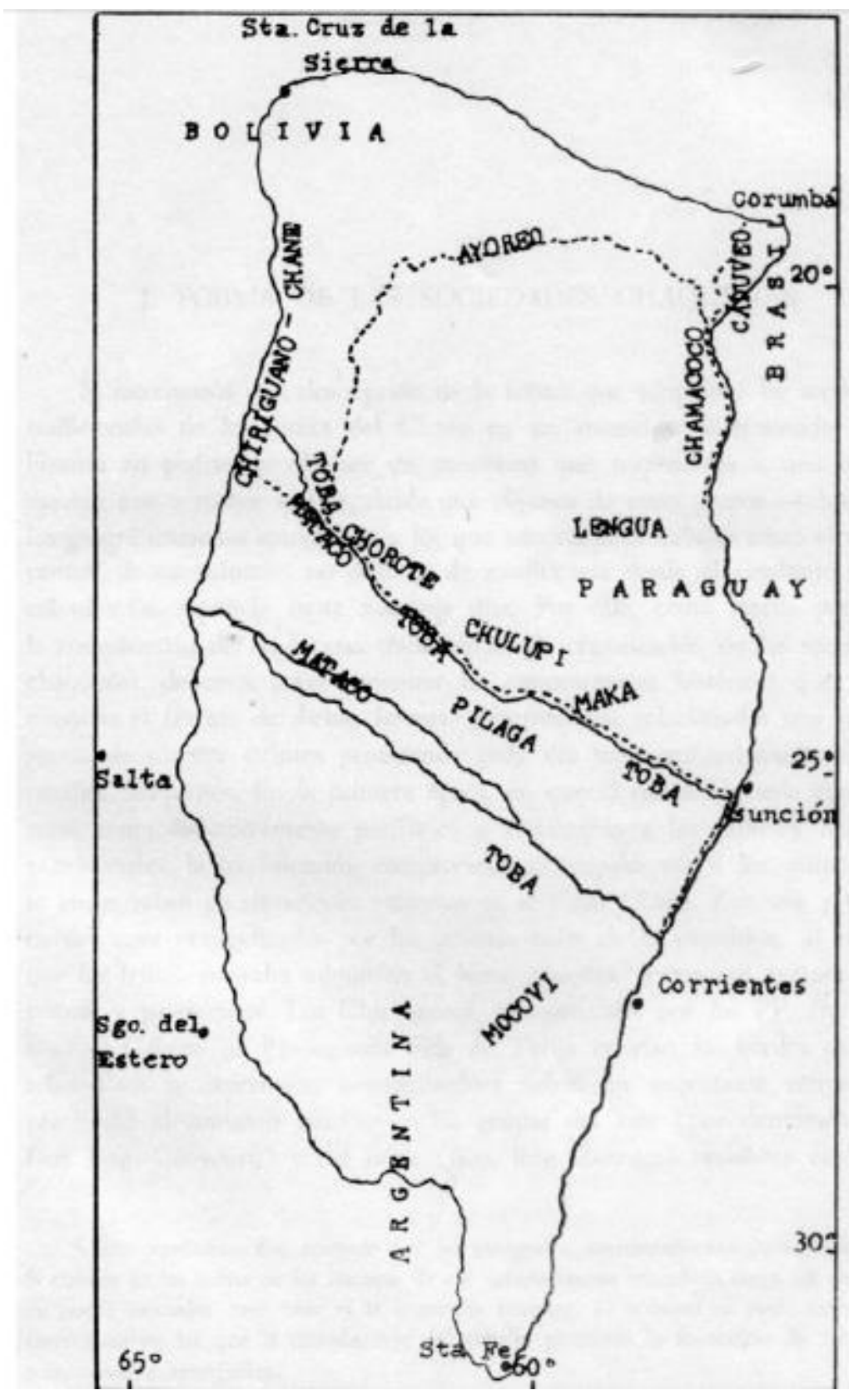

Fonte: Braunstein (1983:7)

Essa relação dos portugueses com os índios, por sua vez, é entendida por Richard e Combès (2015: 247) como um dos motivos para a "crise" do complexo Eyiguayegui-Guaná. Sem precisar mais da proteção dos “índios cavaleiros" e nem 
mesmo de seu papel de intermediários, eles teriam começado a entabular relações diretas com os lusitanos, deixando cada vez mais de lado sua relação de "servidão" com os Eyiguayegui. Essa hipótese é corroborada por alguns dados das fontes, que narram a gradual aproximação de alguns chefes guaná dos fortes portugueses. Rodrigues do Prado (1795: 43), por exemplo, afirma que já em sua época os Guaná passaram a perceber "a superioridade do seu numero", passando então a "sacudi[r] o jogo tyrannico a que estavam submetidos". Prova disso seria que, "no anno de 1793, no mez de Junho" foram "ao presidio da Nova Coimbra pedir a proteção dos Portuguezes mais de trezentos, conduzidos por um sobrinho do chefe de sua nação, ao qual chamam capitão Guassú, que em língua geral quer dizer Grande”. Em recompensa, teriam recebido dos portugueses "sapatos, fivelas de prata, botas, camisas de punhos, bastão, e outras cousas de valor". Aos poucos, as fontes começam a narrar aquilo que antes seria (em sua concepção) inimaginável: o desmantelamento da "vassalagem” por iniciativa dos próprios "vassalos” e sua opção de lutar ao lado dos portugueses e contra os Eyiguayegui - seus antigos "senhores" - em algumas batalhas (Rodrigues 2009: 46).

A seguinte citação de Azara (1809: 230) é também fundamento para o argumento de Richard e Combès:

Vê-se cotidianamente grupos de cinquenta a cem Guaná descerem
para o Paraguai para oferecerem aos espanhóis seu trabalho como
agricultores e, inclusive, como marinheiros, [...] Quando entram em
território espanhol, deixam suas armas no primeiro Juez de Paz que
encontram para recuperá-las ao voltar. [...] As tropas guaná tomam
frequentemente essa última opção [retornar a suas aldeias] após um
ou dois anos, levando consigo o que ganharam, ou seja, roupas e
utensílios de ferro.

Alguns Guaná trocaram, portanto, as visitas às tolderias pelas visitas aos fortes portugueses, oferecendo-lhes seu serviço nessas ocasiões. Quando lida à luz da etnografia de Bonilla supracitada, esse dado se abre a outra possibilidade de interpretação: mais do que terem deixado de ver utilidade nos capitães eyiguayegui por conta de sua então reduzida capacidade de proteção e intermediação, os Guaná podem ter passado a enxergar os portugueses como, primeiramente, "predadores" muito mais perigosos que os Eyiguayegui e, em segundo lugar, "patrões” que podiam despender cuidados muito maiores que os dos índios cavaleiros. No mais, não podemos deixar de reconhecer que o interesse no cuidado dos europeus, que lhes rendia uma sorte de produtos manufaturados, estava imerso numa rede de relações mais ampla "onde o ser como os brancos - e o ser dos brancos - era um valor disputado no mercado simbólico 
indígena" ${ }^{101}$, por conta do perigo sedutor que eles representavam. Nesse sentido, os produtos europeus, "além de sua óbvia utilidade, eram também signos dos poderes da exterioridade, que cumpria capturar, incorporar e fazer circular [...]”. Uma parte do privilégio que os Eyiguayegui gozavam enquanto intermediários, portanto, parecia provir de sua capacidade de fazer circular o que vinha de fora. Aquilo que muitos estudiosos consideram o período de seu declínio, portanto, corresponde ao momento em que seus capitães deixaram de ser os grandes propulsores da circulação de bens estrangeiros por conta da gradativa diminuição de suas expedições de visita e guerra. Nesse mesmo período, os europeus conseguiram entradas antes impossíveis ao centro chaquenho, o que fez as populações de seu interior terem um acesso direto a seus bens.

O gradual isolamento dos Eyiguayegui pôde ser melhor documentado na metade do século XIX, quando a penetração dos não-índios no Gran Chaco, antes movida por motivos militares e missionais, passou cada vez mais a servir a interesses econômicos. No início daquele século, as atividades pecuárias e agrícolas passaram a invadir as planícies chaquenhas, isolando cada vez mais os Eyiguayegui e todas as outras populações indígenas ${ }^{102}$. Os Eyiguayegui do lado oriental do Rio Paraguai faziam algumas incursões guerreiras ao lado ocidental do rio, mas essas eram cada vez mais raras, visto que suas terras estavam ameaçadas por fazendeiros portugueses que começaram a se instalar na região de Miranda, no Mato Grosso do Sul.

Na última metade do século XIX, algumas de suas tolderias se engajaram em batalhas da Guerra do Paraguai ${ }^{103}$, onde lutaram pelo domínio de suas terras. A participação dos Eyiguayegui na guerra se inseria em um quadro de inimizade com outros povos aliados aos paraguaios, além de ser o prolongamento de um processo mais antigo de relação com os portugueses, que vinha, como afirmado, desde o século XVII. Nesse conflito, eles não apenas atuaram como "remeiros, carregadores, guias, militares" em conjunto com as tropas lusitanas, mas também formaram suas próprias "milícias", atualizando seu gosto pela guerra ${ }^{104}$. Algumas de suas batalhas foram descritas pelo então engenheiro militar do exército brasileiro Alfredo d'Escrangolle Taunay, que conta, por exemplo, sobre a ocasião em que os Eyiguayegui se "aproveitaram [d]o ensejo para atacar os paraguayos no Apa, assim como para

\footnotetext{
101 Viveiros de Castro (2002: 224).

102 Braunstein (1983:9).

${ }^{103}$ Maior conflito armado internacional ocorrido na América do Sul, a Guerra do Paraguai foi travada entre o Paraguai e a chamada Tríplice Aliança (constituída por Brasil, Argentina e Uruguai) entre 1864 e 1870. A guerra tinha como plano de fundo a disputa dos países envolvidos pela hegemonia da Região da Prata, que garantia, à época, o livre comércio com a Europa. Sobre a participação dos Eyiguayegui na Guerra do Paragui, ver Corradini (2007 e 2014).

${ }^{104}$ Rodrigues (2009: 54).
} 
assassinar famílias brasileiras [...]”, em dezembro de 1864 (Taunay 1931:26). Segundo os interlocutores kadiwéu de Mônica Pechincha (1994: 153), os brasileiros

precisaram do Kadiwéu para assegurar o território da nação. Houve uma aliança temporária, atendendo as necessidades de ambos os povos que, contudo, não se confundem. O Kadiwéu não é brasileiro, luta não pelas terras brasileiras, mas por suas terras, que também estavam ameaçadas, porque dentro do território brasileiro. Índios guerreiros elegeram uma guerra como evento fundamental na história da relação com os brancos. Porque é guerreiro, irá defender as suas terras, reeditando atos descritos pelos mitos que contam sua história. Porque é guerreiro, venceu para os brasileiros a Guerra do Paraguai. Porque é guerreiro, ganhou as suas terras.

Já no início do século XX, o Dr. José Manoel de Barros Maciel e seu ajudante, o agrimensor francês Émile Rivasseau, foram contratados pelo governo de Matto Grosso $^{105}$ para demarcar as terras sob domínio do governo brasileiro, além do território Kadiwéu ${ }^{106}$, que lhes havia sido cedido pelo imperador D. Pedro II no tratado de paz de $1791^{107}$. O francês acabou descrevendo intensos conflitos dos índios Eyiguayegui com um fazendeiro português, ex- coronel da Guarda Nacional de Matto Grosso, e dono da fazenda do Barranco-Branco. Por conta desses conflitos, algumas expedições do exército brasileiro foram enviadas às terras dos Eyiguayegui que, mesmo sob pressão do governo brasileiro, tiveram suas terras demarcadas oficialmente em 1903, ocupando grande parte de seu território atual, na margem brasileira do Rio Paraguai ${ }^{108}$. Já nessa época, os viajantes e representantes do Estado brasileiro denominavam os habitantes daquelas terras como Kadiwéu ${ }^{109}$, etnônimo que seria uma corruptela de Cadiguegodi - segundo Susnik (1972: 77), "oriundos de onde cresce a planta cadi (planta não identificada pela autora) -, uma das "parcialidades" dos Eyiguayegui chaquenhos. De fato, já no século XIX Almeida Serra (1845:206) havia denominado uma das parcialidades dos Eyiguayegui como "Cadiué-os”, que contariam com aproximadamente 680 pessoas em suas tolderias. Em sua rápida (mas profícua) passagem pelos Kadiwéu em 1935, o antropólogo francês Claude Lévi-Strauss (1996: 184) faz um levantamento de 200 pessoas habitantes das antigas tolderias, agora denominadas aldeias. Pouco mais de dez anos depois, entre 1947 e 1948, Darcy Ribeiro fez campo os Kadiwéu e contabilizou algo entre 235 pessoas (Ribeiro 1980a:56).

\footnotetext{
${ }^{105}$ Então província do Estado brasileiro, cujo traçado incluía os atuais estados do Mato Grosso e do Mato Grosso do Sul.

${ }^{106}$ De acordo com Rivasseau, a terra destinada aos Eyiguayegui se situava entre o córrego Niutaca, ao norte, a serra de Bodoquena a leste, o rio Aquidauana ao sul e os rios Paraguai e seu braço Nabileque a oeste (Rivasseau 1934:55). Sobre o processo de demarcação da Terra Indígena Kadiwéu e as mudanças em seus limites, ver José da Silva (2004; 2011).

${ }^{107}$ Siqueira Jr. (1993:192).

${ }^{108}$ José da Silva (2011:49).

${ }^{109} \mathrm{Ou}$ Caduveo e Cadiueo.
} 
Até esse momento, os limites das terras Kadiwéu não era oficial e os índios aproveitavam para formar aldeias em locais de grande circulação. É o exemplo da aldeia Xatelodo, que “(...) ficava próxima à trilha que os Kadiwéu usavam para chegar à estação ferroviária Guaicurus, constituindo-se uma importante parada para a maioria dos que viajavam para as cidades, gerando ocasiões propícias para a manutenção das relações intercomunitárias" (José da Silva 2011: 60). As incertezas a respeito do limite do território kadiwéu, porém, trazia também consequências negativas: nessa época, diversos fazendeiros não-indígenas começaram a pedir autorização ao Serviço de Proteção ao Índio (SPI) para arrendar as terras kadiwéu. Os pedidos eram oficialmente negados, mas grande parte dos funcionários do órgão estatal via com bons olhos essa ocupação, deixando-a aumentar cada vez mais (José da Silva 2011: 62).

Mapa 3 - Mapa chaquenho da primeira metade do XX

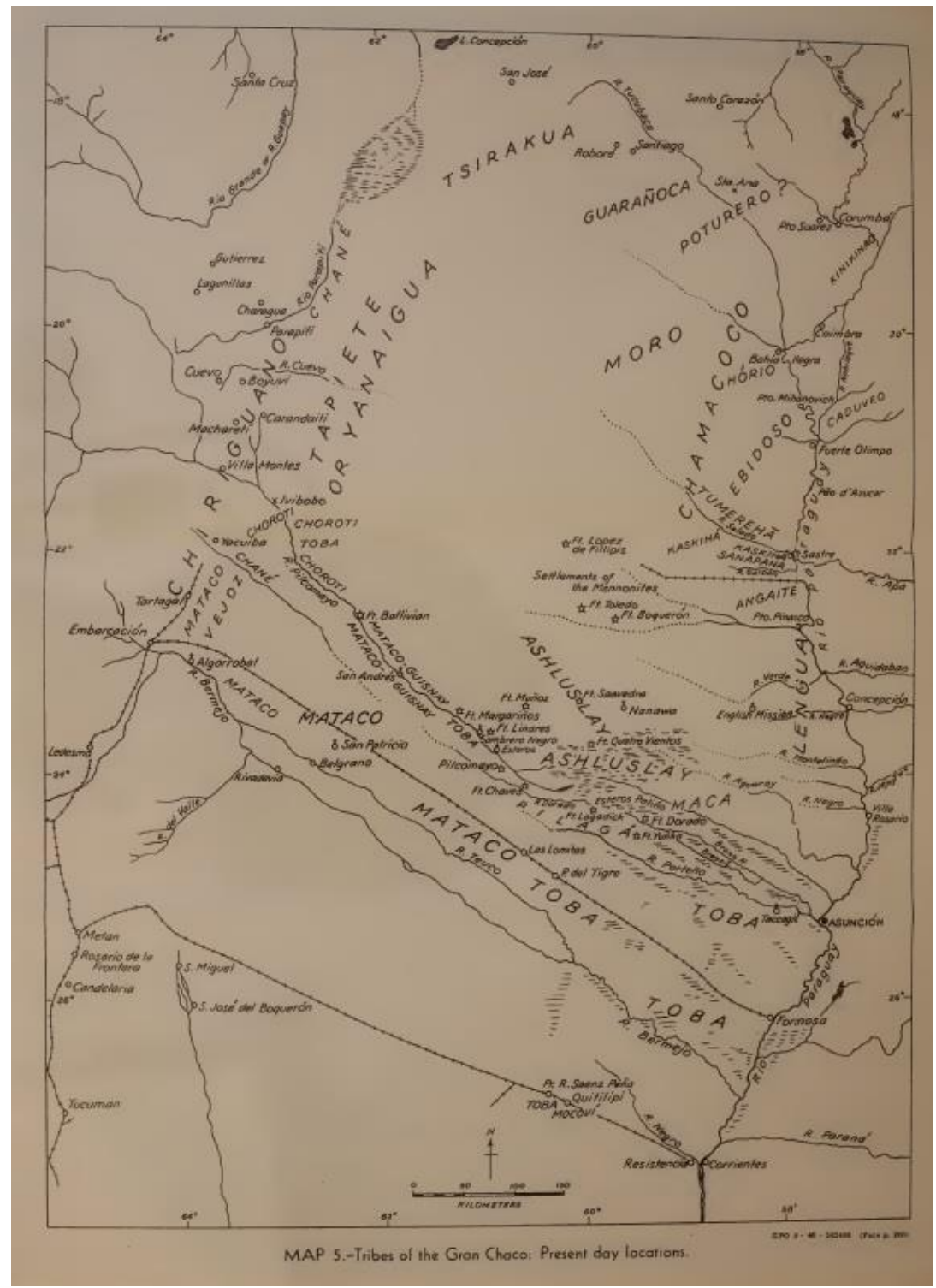

Fonte: Métraux (1946: 200) 
Foi nessa época em que o coronel Horta Barbosa trouxe algumas famílias kinikinau e terena para viverem dentro da R.I. Kadiwéu, com a intenção de "povoá-la”, evitando mais invasões ${ }^{110}$. A aldeia São João, reconhecida na literatura como "mais terena”, foi constituída neste período.

A demarcação oficial e definitiva da Reserva Indígena Kadiwéu foi empreendida pela Fundação Nacional do Índio (Funai - órgão que substituiu o SPI) no início da década de 80. "Na época", segundo José da Silva (2011: 69), a Funai se mostrou favorável à continuidade dos arrendamentos, ainda que os índios fossem contrários a ela. “O 'capitão' Kadiwéu João Príncipe, por exemplo, denunciou que pecuaristas e posseiros da região da Serra da Bodoquena estavam invadindo e demarcando terras dentro dos limites da área indígena, chegando a proibir os índios de cuidarem de suas plantações”.

Iniciou-se, assim, outro ciclo de guerras e visitas entre kadiwéu e fazendeiros do Mato Grosso do Sul, narradas por viajantes (Boggiani e Rivasseau) e antropólogos como Jaime Siqueira Jr. (1993), Mônica Pechincha (1994) e Lisiane Lecznieski (2005). As dissertações e teses desses três antropólogos trazem diversas descrições sobre as relações de arrendamento das terras kadiwéu pelos fazendeiros da região, que acabou por criar laços empregatícios, econômicos e de parentesco entre índios e não-índios, além de conflitos permanentes. As categorias cativo e capitão também são largamente discutidas até os dias atuais: como mencionado, algumas famílias Terena e Kinikinau têm suas aldeias localizadas na R.I. Kadiwéu, e muitos descendentes de cativos se reconhecem como tal. As etnografias supracitadas fizeram grandes avanços na tentativa de entender as distinções operantes nas tolderias/aldeias Eyiguayegui e Kadiwéu. A leitura paralela das etnografias atuais e das fontes históricas é base para os próximos capítulos.

${ }^{110}$ José da Silva (2011:61). 


\section{Capítulo 2. Elementos de diferenciação eyiguayegui}

O filho do capitão nasce no toldo central ${ }^{1}$.

Aos poucos, todos os habitantes da tolderia tomam conhecimento do fato. As velhas pintam imediatamente seu rosto com nibadena - tinta do urucum. As moças e velhas do toldo do capitãozinho começam a tecer, muito entusiasmadas, uma esteira cujos materiais são fios de várias cores, que se entrelaçam formando aquele que será futuramente o berço da criança. Todas se esmeram em manifestar o prazer que aquela atividade lhes proporciona. Essas mesmas mulheres - velhas e jovens - competem pra amamentar seu capitãozinho, tornando-se todas suas amas de leite.

Alguns homens da tolderia organizam uma expedição para ir em busca do mel, base do nudagi - bebida alcoólica. A aproximadamente doze metros do toldo do capitãozinho, levantam-se quatro esteiras que dão origem ao toldo de armazenamento do hidromel. Até agora, porém, ele está repleto de potes vazios à espera do nudagi. Doze homens anciões pintados e armados guardam a cabana: não confiam o cuidado da taberna senão a homens respeitados e de juízo. Assim que é trazido, o mel é depositado nas vasilhas e passa pelo processo de fermentação na cabana.

As velhas e moças fazem várias rodas em volta do bebê, dançando e cantando de mãos dadas e fazendo-lhe reverências. O baile das mulheres dura até depois do poente, seguindo noite adentro.

Durante as manhãs dos sete dias seguintes, ao nascer do sol, os nachigue tenagadi - jovens instrumentistas eyiguayegui - tocam a corneta e o tambor ao lado do toldo central, chamando aqueles que devem expor sua criatividade. As canções de um velho nibotagi acompanham as batidas do tambor. Quando o sol nasce, ele canta as felicidades que estarão presentes na longa vida do bebê. Ele destruirá inimigos e será conhecido por suas façanhas. O nibotagi canta apenas felizes anúncios e, em troca, recebe uma manta em nome do recém-nascido.

Chegam ao toldo do bebê 18 pessoas dispostas em duas fileiras pareadas. À frente estão dois jovens eyiguayegui devidamente pintados. Cada um leva nas mãos duas flechas com bandeiras nas pontas. Na outra extremidade a flecha está ornamentada com diversas plumas de várias cores. As outras 16 pessoas que seguem os

\footnotetext{
${ }^{1}$ A descrição da festa celebrada no nascimento do filho do cacique fundamenta-se nos dados trazidos por Sánchez-Labrador ([1770-1776], v. II: 14-18) e em sua sistematização feita por Mônica Pechincha (1994: 42-44).
} 
guerreiros são mulheres e, com exceção de quatro, todas elas são as mais velhas da tolderia.

Os dois jovens guerreiros caminham e dançam tocando a terra com as pontas das flechas, fazendo várias contorções com o corpo. Ao mesmo tempo, cantam em saudação ao capitãozinho. Depois de terem andado cerca de 20 passos eles param sem interromper a dança e o canto, dando lugar às senhoras, que saem das filas dirigindo-se àqueles que os assistem. A primeira, muito velha e cheia de pinturas, segura uma flauta entre os dentes, soprando-a de quando em quando, em um sibilo desalentado. A segunda leva lanças e, as outras, arcos e flechas. Todas estão cobertas por suas tradicionais mantas e em seus braços e ombros há uma variedade de desenhos pretos, vermelhos e brancos. Quatro delas levam nas mãos ou mesmo na cabeça perucas de crina de cavalo, nas quais estão presas algumas plumas. A procissão percorre todos os toldos duas ou três vezes.

Enquanto isso, na frente da cabana do nudagi, um tambor é tocado incessantemente durante o tempo de fermentação, convidando os vizinhos para a bebedeira. Os homens que estavam a guardar o toldo experimentam a bebida e dizem se aprovam. Depois de passar por sua decisão, o nudagi é levado para as esteiras do capitãozinho, onde as fileiras de guerreiros e guerreiras têm sua parada final.

Ali todos almoçam, bebem nudagi e se divertem com os jogos do touro - lutas de socos entre duplas de mulheres e de homens - e do cervo - espécie de pega-pega em que uma pessoa segura os chifres de cervos acima da cabeça e foge dos outros participantes -, que tem como figuras centrais os jovens pintados e as velhas. Durante a bebedeira, o nachigue tenagadi toca e canta, celebrando o valor dos bebedores, enquanto algumas pessoas servem o nudagi em cabaças. Os que beberam (alguns homens e mulheres) vomitam e ficam incapacitados de andar até seus toldos, precisando da ajuda daqueles que não se embriagaram. Esse ciclo se repete durante os sete dias, tendo pausas apenas nas horas do sono. Nos momentos despertos, a borracheira, as danças e os cantos são o que move os toldos.

No penúltimo dia da festa - o sétimo -, o pequeno capitão faz um amigo. Escolhe-se um recém-nascido nibotagi a quem será concedido o título de capitão menor. À tarde, quando cai o sol, levam o capitãozinho e seu dossel colorido ao toldo de seu novo amigo. Os dois dormem juntos naquele toldo por toda a noite, como se fossem irmãos. De manhã homens e mulheres se vestem de folhas, outros se pintam, e todos formam uma procissão muito ordenada, que acaba no dossel do capitãozinho. Ao lado do cacique uma velha canta e dança. Outras vão ao dossel do recém-feito capitão. Fecha 
a comitiva um nibotagi com um cavalo, que será dado de presente ao capitãozinho como agradecimento pelo título do outro recém-nascido. Depois todos vão ao toldo do capitão, onde as crianças ficam o dia e a noite inteiros. A usual borracheira segue. No outro dia, o novo capitão volta a seu toldo.

Depois, homens e mulheres bebem até se embriagar e os jovens jogam peteca, feita de raízes da mandioca e plumas coloridas. Jogam também o jogo das máscaras, em que uma moça vestida com folhagens e com o rosto pintado de carvão foge dos rapazes, que seguem em seu percalço, tentando tirar-lhe as folhagens. Quando conseguem agarrá-la, levam-na ao rio para que tire o pó de carvão do rosto. A moça ganha do capitãozinho uma outra manta. O fim da celebração se dá quando o cabelo do capitãozinho é cortado e os lóbulos de suas orelhas e seu lábio inferior são perfurados.

Considerada por Sánchez-Labrador ([1770-1776], v. II: 14) a festa eyiguayegui mais completa, “[...] un compendio de cuantas diversiones se celebran en el círculo del año", a cerimônia de criação do capitão ${ }^{2}$ parecia condensar elementos de diferentes esferas da vida social daqueles índios ${ }^{3}$. Além das relações entre capitães e nibotagi, também relações geracionais e de gênero encontravam espaço de ação na festa. É na descrição dessa cerimônia que as distinções eyiguayegui aparecem com mais clareza: os capitães maiores e menores, os nibotagi, as mulheres e homens velhos, as mulheres e homens jovens, os guerreiros, os tamborileiros... Mesmo o jesuíta que nos traz este relato se diz instigado pela festa a procurar entender melhor as distinções operantes em suas tolderias. O presente capítulo também se inspira na descrição de SánchezLabrador para destrinchar essas diferenciações, mas pretende ir além da proposta do missionário, mostrando como a noção de trabalho influenciou e ainda hoje influencia a leitura das relações entre essas categorias.

\footnotetext{
${ }^{2}$ Decidi manter a denominação de Sánchez-Labrador ([1770-1776], v. II: 19), "cerimônia de criação do capitão", para enfatizar os processos de fabricação da nobreza e da chefia entre os Eyiguayegui, já evidentes mesmo para quem, como ele, tenderia a pensar na chefia como algo automaticamente dado por nascimento.

${ }^{3}$ Entendo a festa da criação do capitão como um evento "completo" de forma parecida com a leitura que Sztutman (2012: 190-1) faz das cerimônias antropofágicas tupi, que afirmariam relações entre o matador e sua vítima, grupo convidado e anfitrião, homens e mulheres, deuses e humanos... A festa do capitãozinho (assim como a festa da moça descrita no próximo capítulo) remete até mesmo ao potlach da Colúmbia Britânica, considerado por Mauss (2003) um "fato social total" por agregar elementos dos mais variados campos da vida social, e ao mesmo tempo não se resumindo a nenhum deles. De maneira similar ao potlach, portanto, a festa do capitãozinho não pode ser resumida à "economia", ao "ritual" ou à "política" tais como os entendemos pois, sendo as distinções eyiguayegui (e mesmo ameríndias) outras, recortá-las a partir de nossas categorias não contribuiria para sua leitura. Discuto adiante as festas eyiguayegui em diálogo com a reflexão feita por Perrone-Moisés (2015).
} 
A festa de criação do capitão ilumina diferentes aspectos do que chamaríamos de política eyiguayegui, dos quais podemos citar, no momento, pelo menos três. Em primeiro lugar, coloca o capitão na posição central. Ao contrário do que poderíamos imaginar, porém, essa posição não é ocupada por uma noção de poder ou de superioridade: ela está intrinsecamente ligada ao papel de anfitrião do capitão e de seu filho, o capitãozinho. Seu toldo é palco para todas as borracheiras durante o “octavário”. No mais, a maior parte das dádivas que aparecem na descrição de SánchezLabrador (as mantas de algodão) são presentes do capitão para os nibotagi, ou para outras pessoas que têm papel de destaque na festa, sendo a generosidade do capitão extremamente valorizada. Por fim, os oito dias de festa são repletos de atos guerreiros: veremos no próximo capítulo que as pinturas utilizadas pelos jovens e pelas senhoras, o tambor tocado pelos nachigue tenagadi e mesmo as previsões do velho guaná fazem parte de uma rotina de guerra. A construção do capitãozinho como anfitrião, generoso e guerreiro exemplar é o ápice da festa.

Esses aspectos da chefia eyiguayegui iluminados pela cerimônia serão discutidos no presente capítulo. Os outros dois, a saber, a constante fabricação do corpo operada na cerimônia e as possibilidades de rearranjo dos estatutos - em que um nibotagi pode virar capitão, por exemplo - serão discutidas no próximo capítulo. Pois parece ser essa constante reconstrução, ou mesmo instabilidade ${ }^{4}$ dos corpos eyiguayegui, que permitem a não-fixidez das categorias, ainda que existam algumas predisposições a um ou a outro estatuto. Um cativo de guerra, por exemplo, traz em si uma marca de exterioridade que o faz ser, inicialmente, um nibotagi. Um filho de capitão, por outro lado, tem em si uma predisposição à chefia. Mas essas posições podem se rearranjar, dependendo das aptidões desenvolvidas e demonstradas pelas pessoas. Antes de entrar nesse ponto, porém, é necessário entender como e por que essas aptidões foram dispostas em uma gradação hierárquica por documentos históricos e análises antropológicas.

No capítulo anterior afirmei que entender as distinções eyiguayegui como “apenas” subjetivas acaba por trazer mais contradições à sua suposta hierarquia do que esclarecê-la. As diferentes categorias sociais descritas por viajantes, missionários e militares eram um dado do vivido, e não apenas do imaginado, ainda que tenham sido lidas de maneiras muitas vezes equivocadas. O grande problema, na maioria das vezes, é que a confusão feita pelos documentos históricos perdura mesmo nas produções

\footnotetext{
${ }^{4} \mathrm{O}$ caráter transformacional e instável dos corpos não apenas eyiguayegui mas ameríndios, tal como apresentado por Vilaça (2005) será discutido no próximo capítulo.
} 
atuais: a diferença entre capitães e criados, por exemplo, é usualmente explicada por antropólogos como fundamentada em relações de servidão. A fim de iluminar o conceito de "servidão", basilar para a "hierarquia" chaquenha ${ }^{5}$, proponho um olhar mais atento à noção de trabalho que, embora seja fundamental para a qualificação de uns como "nobres" e de outros como "escravos", ainda não foi analisada profundamente. De fato, parece ser no encontro entre essas duas noções que a "estratificação social" eyiguayegui começa a tomar forma: é perceptível a associação direta entre (um determinado tipo de) trabalho e servidão efetuada não apenas nos documentos históricos, mas também em análises antropológicas.

Essa conexão automática entre as duas noções, por sua vez, parece ter origem na forma como foram vistas as diferentes atribuições eyiguayegui. Em primeiro lugar, os autores das fontes já distinguiam o tipo de tarefas realizadas, ou seja, o que "nobres" e "escravos" faziam de acordo com seus próprios termos. De saída, algumas atribuições (categorizadas como "trabalho") eram entendidas como inferiores às outras. Em segundo lugar, há uma preocupação com a maneira pela qual se realizavam as tarefas, ou seja, como os "escravos" e "servos" executavam algumas atividades. De acordo com as fontes e alguns antropólogos, a particularidade dos nibotagi e niyolola era que eles não apenas executavam certas tarefas, mas as faziam a serviço de seus "senhores", servindo-os em qualquer momento. Sugiro que na base dessa visão estão certas definições de trabalho e servidão que fazem com que atividades diferentes - mas não necessariamente percebidas pelos índios como desiguais em valor - sejam vistas como base de uma hierarquia.

Como demonstro adiante, a noção de trabalho parece estar, desde sua origem, vinculada à ideia de poder que acaba sendo transplantada para nossas análises. Minha sugestão, portanto, é a de refinar nosso vocabulário quando nos referimos às tarefas realizadas pelos índios. No lugar de trabalho, utilizo daqui em diante o termo atribuição quando estiver me referindo aos afazeres das pessoas, tentando, ao mesmo tempo, me afastar do pressuposto de que essas relações se fundamentam na exploração e me aproximar do que uma vez disse Eduardo Viveiros de Castro: o trabalho não é a essência do homem (e nem da mulher) - "a atividade talvez seja, mas trabalhar não”6.

\footnotetext{
${ }^{5}$ Assim como para outras organizações ditas hierárquicas; ver Perrone-Moisés \& Lolli (2017).

${ }^{6}$ Em entrevista concedida a Rafael Cariello, para a Revista Piauí, ed. 88.
} 


\subsection{Elementos de diferenciação eyiguayegui}

\subsubsection{Estatutos "vocacionais"}

Passavam de vinte aqueles que se denominavam chefes na redução Nossa Senhora de Belém7. A princípio, Sánchez-Labrador conjecturou que ascender a tal posto não seria assim tão difícil, levando em consideração o vasto número de pessoas distintas por meio daquele "nome marcial". Todos os chefes deviam adquirir seus títulos à custa de algumas façanhas e provas de coragem, imaginava ele, "coisa ordinária em outras nações da América”. A festa de criação do capitão, porém, provou para o missionário que as coisas eram mais complicadas: em seu diário, ele escreve que, ao contrário do que pensava, as proezas não eram suficientes para elevar ao maior título de capitão aqueles que não eram sublimados pelo sangue ou pelo favor do capitãozinho recém-nascido ${ }^{8}$. Segundo o jesuíta, era necessário que o cacique recebesse seu título por leis da hereditariedade. Séculos mais tarde, sua descrição da festa - que não é mais celebrada - acabou por basear as "recorrentes afirmações sobre a ‘importância do cacicado hereditário’ entre os Kadiwéu” (Lecznieski 2005: 201).

De fato, a festa lança luz sobre os dois tipos de "nobreza" eyiguayegui. O primeiro era composto pelos que "goza[va $] \mathrm{m}$ daquela regalia" por conta de seu sangue e o segundo por aqueles que a recebiam em outras ocasiões, como a festa acima descrita. Todos se chamavam niniotagi. Ao capitão grande - o herdeiro da capitania dava-se o nome de niniotageleudi, uma junção de iniwtagodi (meu senhor) e eleudi (grande). Este último adjetivo, eleudi ou elegi, era sua forma de denominação mais cotidiana. O capitão pequeno chamava-se niniotagilionigi, onde niniotagi pode ser traduzido como "capitão" ou "senhor" e ionigi como "filho". Os capitães pequenos eram também denominados inionigi-iguaga, ou "semelhante a capitão" 9.

O título de elegi era aplicável não apenas aos capitães grandes, mas também a suas mulheres e filhas. Ainda que os documentos históricos afirmem muitas vezes que a nobreza era transmitida via linha paterna, eles trazem dados também de elegi filhos apenas de uma "senhora" e de pai "comum" ou mesmo nibotagi. O título de niniotageleudi podia, portanto, ser transmitido tanto por linha paterna quanto materna $^{10}$, e não havia uma propensão maior para o lado masculino, como em outros

\footnotetext{
7 Sánchez-Labrador [1770-1776], v. II: 19.

${ }^{8}$ Sánchez-Labrador ([1770-1776], v. II: 19, tradução minha).

9 A denominação dos capitães é informada por Sánchez-Labrador ([1770-1776], v. II: 19) e a tradução dos nomes é trazida por Mônica Pechincha (1994: 34).

${ }^{10}$ Cabeza de Vaca ([1555]:159).
} 
$\operatorname{contextos}^{11}$. Tampouco há dados que demonstrem uma menor potência da nobreza quando apenas um dos pais era nobre: segundo as fontes, capitães grandes podiam ser filhos tanto de pai e mãe nobres como apenas de um pai ou mãe de linhagem aristocrática.

Os elegi - também denominados por Sánchez-Labrador "caciques" - eram os chefes das tolderias, apresentando características muito parecidas com aquelas do titular chief (ou "chefe titular") de Robert Lowie (1948: 273-6). A generosidade, a boa oratória e a habilidade de agregar um grupo de pessoas e mantê-lo em certa harmonia eram certamente requisitos de um bom elegi $^{i^{2}}$. Aliado a esses aspectos, a posição de chefia parecia ser também esvaziada de poder, como no modelo proposto por $\mathrm{P}$. Clastres (2003) inspirado nas observações de Lowie. Apoiado em sua tese de que as sociedades indígenas americanas são sociedades contra o Estado, o etnólogo francês encontra a conjuração do poder centralizado primeiramente na "filosofia da chefia indígena"13: segundo o etnólogo francês, o chefe ameríndio ocuparia um posto esvaziado da possibilidade de efetivamente poder exercer alguma autoridade; longe de poder mandar ou punir seus "chefiados", muito pelo contrário, ele seria praticamente um prisioneiro do grupo. A função da chefia nas terras baixas sul-americanas aparece em Clastres, portanto, mais como um encargo do que como privilégio ${ }^{14}$ : obrigado a representar seu grupo e a mantê-lo unido, suas contrapartidas seriam praticamente nulas, visto sua ausência de poder. A descrição de Paul Radin (1946) baseada no testemunho do jesuíta Martín Dobrizhoffer ([1784]) sobre o posto de “cacique” entre os povos de língua Guaicurú é exemplar desse caso. Segundo o antropólogo, ser capitão entre aqueles índios era

mais uma carga do que uma honra e com frequência este posto traz [ia $]$ mais perigo do que proveito. Pois não reverencia $[\mathrm{va}] \mathrm{m}$ a seu cacique como um mestre nem lhe paga $[\mathrm{va}] \mathrm{m}$ tributo ou ajuda como é costume em outras nações. Não o invest [ia $] \mathrm{m}$ com a autoridade de um juiz, um árbitro ou um vingador... Se repreend[ia] alguém por suas transgressões, com uma só palavra dura ser[ia] castigado na seguinte bebedeira, para beber com os punhos dos selvagens embriagados, e o encheriam publicamente de insultos, como amigo dos espanhóis e como alguém que ama mais a tranquilidade do que a seu povo (Radin 1946: 188, tradução minha).

\footnotetext{
${ }^{11}$ Refiro-me aqui ao contexto alto-xinguano e, mais especificamente, o Kalapalo, tal como descrito por Guerreiro Jr. (2012).

12 Os interlocutores krahô de Perrone-Moisés (2012: 858) também descrevem um chefe ideal muito parecido: segundo eles, "um bom chefe tem de falar bem, de saber acalmar qualquer briga que ocorra na sua aldeia e dar tudo o que lhe pedirem".

13 A tese da chefia sem poder é primeiramente apresentada no ensaio "Troca e Poder", publicada originalmente em 1962.

${ }^{14}$ Sobre a "filosofia da chefia indígena", ver Clastres (2003), Sztutman (2012) e Perrone-Moisés (2012; 2015).
} 
Os "proveitos" do posto de chefia, nesse sentido, eram poucos. $\mathrm{Na}$ verdade, os elegi pareciam estar sempre tentando atingir o ideal de um bom chefe, que correspondesse às expectativas do grupo. Entre as "cargas" que não apenas os elegi, mas os niniotagi em geral tinham que carregar para continuarem a ser "nobres" estava a função de anfitrião das festas, como vimos na abertura do capítulo. A seguinte descrição de Boggiani ([1895]:188) esclarece esse ponto:

Por quanto tenho observado até aqui parece que os Caduveo gostam de fazer exibição de grandiosidade e generosidade, mal se achem em condições de fazê-lo. Não gostam de embriagar-se egoisticamente sozinhos; precisam para tanto de boa companhia; parece-lhes necessário que todos saibam que tal indivíduo está em condições de oferecer aos amigos o prazer imenso de tomar uma solene bebedeira, que se cante, se dance alegremente, se faça rumor; que os garrafões de aguardente de que dispõe sejam esvaziados com toda cerimônia e com grande pompa; que a memória do festim dure longamente e o anfitrião chegue a superar, com a sua generosidade e o esplendor da sua festa, as festas anteriores.

O esbanjamento descrito por Boggiani não era simples mostra de fartura dos anfitriões, ou apenas a procura pela companhia nas bebedeiras, como interpreta o comerciante. De acordo com a afirmação do próprio italiano, os ofertantes das cerimônias tinham a preocupação de "superar, com a sua generosidade e o esplendor de suas festas, as festas anteriores", ou seja, as festas dos outros anfitriões ${ }^{15}$. Os niniotagi (e também os aspirantes a niniotagi) estavam sob constante pressão de afirmar sua nobreza sobre a dos outros. Essa confirmação, por sua vez, se dava por meio de exibições de "grandiosidade e generosidade". "Embriagar-se egoisticamente sozinho", nesse caso, seria visto como uma grande afronta a seu grupo e como sinal de mesquinhes: um dos grandes xingamentos eyiguayegui era exatamente a acusação de sovinice, acami aquilegi $i^{16}$. A nobreza dos niniotagi é indissociável, portanto, de sua generosidade e capacidade de distribuição: vimos no último capítulo que, assim que voltavam das vilas guaná, os chefes davam aos outros habitantes das tolderias tudo o que haviam recebido de presente. Sendo o momento mais propício para a mostra de generosidade, as festas são centrais na construção da nobreza e dos estatutos eyiguayegui.

Nesse sentido, e como afirma Perrone-Moisés (2015: 53), a festa ameríndia não deve ser vista como acessória à política; ela efetivamente é (o que chamaríamos de) política. Merekuku Apalay, interlocutor da etnóloga, ao comentar que “dono de festa é

\footnotetext{
${ }^{15} \mathrm{O}$ que evoca diretamente as competições em forma de potlatch entre os "chefes" da Columbia Britânica. ${ }_{16}$ "Tú eres un menguado, miserable, mezquino y nada liberal”, segundo Sánchez-Labrador ([1770$1776]$, v. I: 252).
} 
como chefe", resumia a conexão que, segundo a autora, é evidente: como um anfitrião, o chefe deve ser generoso, bom orador, promotor da concórdia ${ }^{17}$; e os chefes ameríndios têm, de modo geral, a obrigação de oferecer festas, de saber cantar e dançar e de ser "detentor" de objetos de festa, como afirmava Boggiani sobre as festas eyiguayegui; em suma, tem que saber como oferecer momentos de alegria (Perrone-Moisés 2015: 5). Por isso Boggiani descrevia anfitriões preocupados em fazer com "que todos saibam que tal indivíduo está em condições de oferecer aos amigos o prazer imenso de tomar uma solene bebedeira, que se cante, se dance alegremente”.

As atribuições dos niniotagi não paravam por aí. A última passagem do excerto de Radin - aquela que coloca em contradição "amar a tranquilidade" e, ao mesmo tempo, "seu povo" - parece remeter a outra característica dos chefes ameríndios tal como descritos na tese clastreana, também presente no Chaco: sua ferocidade e predisposição para a guerra. Segundo P. Clastres, por serem sociedades contra o Estado as populações ameríndias seriam também sociedades-para-a-guerra, sendo a atividade guerreira - e sua consequente pulverização demográfica - entendida como central na conjuração da autoridade ${ }^{18}$. Se a guerra é, para o francês, o motor que faz a sociedade indígena se reinventar em sua recusa do Estado, o chefe acaba por assumir o papel elementar de impulsionar o movimento guerreiro de seu grupo. Ao mesmo tempo em que deve ser generoso e bom anfitrião, agregando em volta de si o maior número de pessoas possível, o chefe ameríndio - e eyiguayegui, como as fontes parecem mostrar deve também ser feroz, lutando contra uma unificação que levaria à centralização (Clastres 2004).

O título de chefe que geralmente é entendido como intrínseco àquele de elegi não se estendia necessariamente à nobreza dos niniotagilionigi - capitães pequenos -, que era apenas vitalícia, não sendo transmissível para as gerações futuras, como no caso dos capitães grandes. Eles podiam adquiri-la nas festas de criação dos capitães e também quando demonstravam certas aptidões para o cargo, como a capacidade de ser um bom anfitrião e a vocação para a guerra. As façanhas e provas de coragem aventadas por Sánchez-Labrador como maneira de ascensão à chefia, portanto, não estavam fora da equação política eyiguayegui. O missionário parece ter se apressado ao

\footnotetext{
${ }^{17}$ Em um caminho inverso, também as relações entre os chefes e suas “turmas”, sugere Perrone-Moisés (2015: 76), podem ser vistas na relação entre "anfitrião e convidado: o primeiro chama, vai à frente, oferece algo; os demais seguem, porque querem, prestam serviço, recebem algo. Anfitrião não manda, tem obrigação de zelar pelo bom relacionamento entre os que reúne, é responsável tanto pelo empreendimento em si quanto por cada um de seus seguidores. Seu prestígio atrai seguidores, tanto mais numerosos quanto forem bem sucedidos os empreendimentos que propicia”.

${ }_{18}$ Dada a suposta correlação entre densidade demográfica e "complexidade sociopolítica"; ver PerroneMoisés e Lolli (2017).
} 
jogar fora essa possibilidade: os "caciques" eram feitos tanto pela hereditariedade quanto pelo "favor" e pelo desenvolvimento de determinadas aptidões.

É importante notar que "comuns" ou nibotagi que apresentassem as qualidades esperadas de um bom chefe podiam muito bem virar capitães de uma tolderia inteira, enquanto pessoas que recebiam, por nascimento, o "título de nobreza" e não se esmerassem em desenvolver as aptidões do cargo, ou cujos pais não investissem na festa de criação do capitão e outras festas iniciáticas, não eram tidas como chefes. A criação gradual do chefe parece ser, nesse sentido, muito mais importante que a hereditariedade da posição. Ainda assim, opto por continuar a utilizar aqui o termo "nobreza", por haver algumas similaridades com a noção europeia: ambas parecem se referir a um porte específico, comedimento e boa educação. Não deixo de notar, porém, que existem grande diferenças entre a "nobreza" eyiguayegui e a dos europeus: a hereditariedade e a "pureza" que parecem ser requisitos no último caso, por exemplo, não são nem de longe o ideal da aristocracia chaquenha. Aliás, um dos aspectos definidores dos "nobres" eyiguayegui, segundo Susnik (1972: 69), era sua "prerrogativa” de manter relações maritais com suas "servas" - as capitãs guaná -, conforme relação descrita no capítulo anterior, e de adotar quantos cativos conseguissem apanhar em guerra.

De acordo com Branislava Susnik (1972: 67), os cativos de guerra da primeira geração, designados iiôdiimiguit, "agarrados”, considerados potencialmente perigosos por serem estrangeiros, ficavam nos toldos de seus captores, podendo ser vendidos a qualquer momento. A eles e aos nibotagi - aqueles da segunda geração, já nascidos entre os Eyiguayegui - cabia o cumprimento de trabalhos considerados pelas fontes "menores", como veremos adiante. A diferença entre os dois estatutos parece ser o grau de "caduveização" 19 nulo ou muito baixo no primeiro caso e já bem maior no segundo. Esse processo de incorporação dos estrangeiros aos Eyiguayegui será discutido no capítulo a seguir. Por ora, devemos atentar à similaridade das duas categorias: a ambas cabiam serviços considerados pelos documentos inferiores, além de sua suposta “obrigação” de servir aos niniotagi. Talvez por isso grande parte da literatura sobre os Eyiguayegui não diferencie nibotagi e iiôdimiguit, denominando-os simplesmente como nibotagi $i^{20}$. Como o presente capítulo visa discutir as atribuições desses estatutos,

\footnotetext{
19 Termo usado por Boggini ([1895]: 354) e discutido no próximo capítulo.

20 Outro motivo para o apagamento do estatuto iôdiimiguit na literatura está no fato de que, aos poucos, os Eyiguayegui deixaram de fazer cativos efetivamente, devido à pressão europeia contrária à guerra ameríndia. Os cativos de hoje em dia - denominados niotagipe (Siqueira Jr. 1993 79) - parecem ser todos descendentes de cativos.
} 
seguirei chamando-os nibotagi, assim como as fontes ${ }^{21}$.

Além dos nibotagi, também eram encontrados "servindo" os capitães aqueles mutirões de "servos" guaná - os niyolola - que vinham trabalhar nas roças eyiguayegui periodicamente ${ }^{22}$. Eles eram contrapostos aos nibotagi e iiôdimiguit por morarem fora das tolderias, em seus próprios aldeamentos. Sua ocupação com tarefas consideradas “ordinárias"23, porém, acabou por fazer com que eles também fossem denominados, muitas vezes, como "escravos". Desse modo, as fontes parecem fazer uma distinção entre os nibotagi - "escravos" co-residentes - e os niyolola - "escravos" estrangeiros.

Entre as "partes" dos niniotagi e dos nibotagi/niyolola havia um grupo considerado intermediário pelas fontes, os uneleiguá. Sánchez-Labrador o identificou como a camada dos plebeus ou comuns, e Rodrigues do Prado a descreveu como a parte dos soldados. Essa "parte" parece ser composta por aqueles que as fontes não conseguiam colocar em nenhum dos polos da oposição entre senhores e escravos. Nele eram colocados aqueles "soldados" que lutavam nas guerras mas não chegavam a ser capitães de guerra e as pessoas que não tinham "sangue" nobre mas se consideravam eyiguayegui "puras". Também parecem compor essa "parte" os nibotagi que lutavam sob o comando dos niniotagi. Essa tripartição não é novidade nas fontes históricas sobre os povos ameríndios, podendo até mesmo ser considerada "clássica": a descrição de sociedades divididas entre nobres, comuns e servos encontra-se também na Colúmbia Britânica, por exemplo (ver Perrone-Moisés \& Lolli 2017).

Ao longo do tempo, as diferenciações operantes nas tolderias eyiguayegui foram descritas por meio de termos como "classes"24, "camadas"25, "níveis”26 e até "estratos"27, que expressam claramente uma noção de gradação hierárquica. Encontra-se também vocábulos como "parte" ou mesmo "segmento", utilizados respectivamente pelo capitão Rodrigues do Prado (1975) e pela antropóloga Mônica Pechincha (1994). Por não expressar nenhuma noção de superioridade ou dominação de um grupo por outro, como fazem as outras expressões, essa divisão por "partes" ou "segmentos" pode remeter, não por acaso, às subdivisões em metades de algumas populações ameríndias, como as Timbira que, por mais seccionadas que sejam, nunca foram lidas como “sociedades hierárquicas". Porém, elas continuam a remeter a um "todo" virtual, o que

\footnotetext{
${ }^{21}$ No próximo capítulo, que visa discutir os processos de “caduveização”, retomarei essa distinção.

${ }^{22}$ Sánchez-Labrador ([1770-1776], v. I:130).

${ }^{23}$ Aguirre (1793: 478).

24. Almeida Serra (1850: 379).

${ }^{25}$ Siqueira Jr. (1993: 126).

${ }^{26}$ Lévi-Strauss (1996: 179).

27 Siqueira Jr. (1993: 79).
} 
não é o caso, como vimos no capítulo anterior. Daqui em diante, portanto, utilizarei essas expressões quando estiver me remetendo aos documentos ou análises antropológicas que as mobilizam, de modo a demonstrar as diferentes leituras das distinções eyiguayegui.

A opção vocabular de Rodrigues do Prado, porém, não deve ser ignorada: ao descrever as tolderias eyiguayegui como dividida por "partes", o militar nos apresenta distinções que não necessariamente geram o que costumamos chamar "desigualdade social”. Logicamente, essas distinções fazem com que essas pessoas sejam desiguais, no sentido de não serem iguais; suas tarefas, seus corpos e suas relações as fazem diferentes. Mas essa desigualdade, como afirmado, nada tem a ver com a desigualdade social que remete a diferenças de renda e de concentração econômica e política. Nesse sentido, assim como "nobreza", o termo "desigualdade" pode também descrever as relações eyiguayegui quando entendido de maneira mais ampla do que a usual.

Veremos que as relações entabuladas dentro das tolderias são lidas pelas fontes por meio da oposição niniotagi/nibotagi. Praticamente todas as descrições de um nobre presentes nos documentos históricos, por exemplo, são feitas em oposição à de um "escravo" ou "servo", não havendo, pois, nobreza sem que haja "escravidão"/"servidão". A matéria prima dessa distinção parece ser os tipos de tarefas realizadas pelos niyolola, nibotagi e niniotagi, descritas nas fontes como anteriores a eles, definindo-os. A discussão sobre as “índoles” agrícola e guerreira efetuada no capítulo anterior encontra aqui um paralelo: da mesma maneira que, para os registros coloniais, os niyolola teriam certa vocação para a agricultura, os nibotagi teriam vocação para os serviços domésticos. "Vocação" aqui pode ser lida como definida por Weber (2004:77, grifos do autor): "aquilo que o ser humano tem de aceitar como desígnio divino, ao qual tem que se 'dobrar'[ ...]”. A agricultura e os trabalhos “domésticos” aparecem na própria definição do "gênio" dos niyolola e nibotagi, ao passo que os niniotagi eyiguayegui são percebidos como guerreiros, agressivos e preguiçosos, pois estavam sempre às voltas com suas festas, pensando em maneiras de se embriagar. Tendo apresentado preliminarmente as atribuições de um bom niniotagi, apresento nas próximas páginas as tarefas dos nibotagi e niyolola.

Nobres cavaleiros e nobres damas se divertiam nos torneios; estavam livres dos trabalhos subalternos graças a uma população instalada havia mais tempo, diferente pelo idioma e pela cultura, os Guaná. [...] Esses Guaná cultivam a terra e pagam um tributo em produtos 
agrícolas aos senhores mbaiá em troca de sua proteção, para se preservarem da pilhagem e das depredações feitas pelos bandos de cavaleiros armados, entende-se (Lévi-Strauss 1996: 191).

A descrição de Lévi-Strauss, feita com base na leitura dos documentos históricos, versa sobre a já discutida "relação de servidão". Além desse pacto hipotético que teria fundado a relação entre as duas populações, já discutido no capítulo anterior, há outra particularidade dos "servos", como se depreende da leitura do excerto e das fontes: sua especialização nas tarefas da terra, que acabaria por deixar "livres dos trabalhos subalternos" os "nobres cavaleiros", ocupados com a "diversão" proveniente das festas e dos jogos (os “torneios”).

Como vimos, ainda que as fontes descrevam, muitas vezes, os niyolola "servindo" a seus senhores em diversas atividades, sua atenção recai sempre na vocação para a agricultura: "los Guaná" cultivavam "la tierra en trabajosas rosas; pero gran parte de sus sudores" serviam de "alimento para sus amos vagabundos", conta SánchezLabrador ([1770-1776], v. I:305). Seu trabalho da terra seria trocado, por sua vez, pela vocação para a guerra de seus "senhores", como afirma Lévi-Strauss. O "contrato de vassalagem” entre essas duas populações criaria uma relação entre uma sociedade-paraa-guerra e uma sociedade-para-a-agricultura, fazendo-as trocar suas especializações entre si.

De forma parecida, os nibotagi também eram reconhecidos por suas atividades. Segundo os autores, eles eram indispensáveis ao cotidiano dos toldos, pois todos os serviços do seu dia-a-dia estavam ao seu encargo. Fazia parte de suas atribuições “abastecer os toldos dos senhores de água, lenha e coisas semelhantes"28, além de cozinhar, buscar palmas de eyiguá, construir e limpar os toldos, cuidar dos cavalos e, às vezes, caçar e pescar ${ }^{29}$.

É importante notar que, embora existam diversas descrições dos niniotagi fazendo todos esses tipos de tarefas, apenas nibotagi e niyolola são por elas definidos. Boggiani ([1895]:133), por exemplo, afirma que aos escravos competia "os trabalhos grosseiros de serviço e o lavrar a terra”, serviços condizentes com sua condição "selvagem”. De maneira parecida, o antropólogo Fernando Santos-Granero (2009: 95) também relaciona os cativos de guerra às "tarefas mais árduas", definindo-os como "serviçais domésticos". Branislava Susnik (1972: 89), por sua vez, afirma que aos escravos cabia todo o trabalho e conta da ocasião em que os Eyiguayegui se

\footnotetext{
${ }^{28}$ Sánchez-Labrador [1770-1776, v. I]:133, tradução minha.

${ }^{29}$ Métraux 1946:308.
} 
comprometeram a ajudar os portugueses a construir o Forte Bourbon, mas se recusaram a fazer o serviço, deixando-o para seus "escravos", pois o consideravam um "trabalho pesado".

É perceptível que a definição de "escravos" e "servos" como pessoas que se ocupam com certas tarefas está diretamente relacionada à definição de outras pessoas os nobres - que não se ocupam com essas atividades. Lisiane Lecznieski (2005:225), por exemplo, escreve que muitos Kadiwéu não executam "tarefas consideradas árduas e menores", preferindo contratar outras pessoas que possam "lavar roupa no riacho, 'levantar uma casa' ou buscar matéria-prima para 'levantar cerâmica”'. Ela conta que, no início de sua estadia entre os Kadiwéu, seus nobres anfitriões - ela estava hospedada na casa do capitão Paulínio e sua esposa Durvalina, descendentes da família Silva, uma das famílias nobres kadiwéu - insistiam para que ela não fizesse nenhum "trabalho pesado”, "na 'torreira do sol”" pois, segundo eles, esse não era "serviço para brancos” e eles tinham "outras pessoas para fazer esse tipo de serviço" ${ }^{30}$. A antropóloga narra que, mesmo com essa inicial reprovação, ela e seu marido continuaram a fazer atividades consideradas "menores", fato que logo passou a ser aceito pelos Kadiwéu. Tanto que, aos poucos, eles começaram a ser requisitados para efetuar aquele tipo de tarefa para seus anfitriões e familiares. “[S]e nos recusávamos a ser nobres, então que fôssemos cativos!", escreve Lecznieski (2005:201).

A autora conta que atualmente os Kadiwéu contratam, de tempos em tempos, alguém para cultivar as roças. Segundo a antropóloga, eles manifestam abertamente um "desagrado em relação às atividades agrícolas, explicando que a contratação de empregados se deve sobretudo ao fato de se tratar de um trabalho árduo, que maltrata a pessoa, obrigada a passar muito tempo 'com a cabeça rachando no sol”". Nessas ocasiões, eles assumem a posição de "coordenadores do trabalho", assim como os antigos Eyiguayegui faziam com os Guanás1. Não é de se estranhar, portanto, que a maior parte dos agricultores da R.I. Kadiwéu sejam os Terena e Kinikinau, descendentes auto-declarados dessa população chaquenha.

Segundo as etnografias atuais, os Terena e Kinikinau tendem a se concentrar em aldeias separadas da maioria dos nobres kadiwéu, como as aldeias Campina e São João. De acordo com Jaime Siqueira Jr. (1993:128), mesmo sendo "visivelmente mais pobres", seus moradores são reconhecidos por "suas qualidades de lavradores e suas capacidades de trabalho, uma vez que as maiores e melhores roças estão localizadas na

\footnotetext{
${ }^{30}$ Lecznieski (2005:13).

${ }^{31}$ Os “mutirões" de agricultores guaná são descritos no capítulo 1.
} 
Campina”. A vocação dos descendentes dos Guaná para a agricultura é também expressada por Martinho Silva (nobre kadiwéu) quando este conta sobre a época meados nos anos 1940 - em que o SPI realocou algumas famílias Kinikinau e Terena para a RI Kadiwéu constituindo, na ocasião, a aldeia São João (José da Silva 2011:61).

Nas palavras de Martinho,

\begin{abstract}
[e]sses Terenas, vem sendo aliado com os Kadiwéu, sempre vivendo subordinados, os Kinikinau subordinados aos Kadiwéu. Não podia fugir porque eles tinham uma tarefa a fazer [...]. Então eles, os patrícios ${ }^{32}$ disseram: - Então vocês ficam aqui [...], aqui é o canto da nossa área, aqui qualquer coisa, qualquer irregularidade que vocês vê, procuram nos localizar, nos avisar o que está acontecendo. Agora vocês têm obrigação, planta milho, arroz, feijão, tudo o que se dá aqui vocês planta, e nós vamos comercializar entre nós mesmos, lá pelo rio Paraguai, por aí, tudo o que nós conseguir nós entrega aqui, nós não temos como negociar [ …] Nós vamos negociando isso aí, vocês ficam como vigilante nosso, como ponto de segurança nosso. Aí toparam, onde existe o PI São João (Siqueira Jr 1993:130).
\end{abstract}

Os Terena e Kinikinau foram levados à RI Kadiwéu por Horta Barbosa com a intenção declarada de povoar o território para que os ataques de fazendeiros diminuíssem. Segundo Martinho, a "obrigação" dos Terena e Kinikinau seria a de avisar caso houvesse alguma invasão, ficando como "vigilantes", "pontos de segurança”. O relato de Martinho nos faz ver, além disso, que acoplada a essa função encontra-se outra, bem conhecida: a de plantar "milho, arroz, feijão". Segundo o nobre kadiwéu, o estabelecimento dessa obrigação faria com que os recém-chegados não pudessem mais fugir, vocabulário que nos remete diretamente àquele utilizado pelas fontes históricas, que estranhavam o fato de "escravos" e "servos" não escaparem do "domínio" de seus "senhores", ainda que estes lhes dessem total liberdade. Em resposta a essa inquietação de viajantes, missionários e exploradores, a fala de Martinho parece sugerir que essa relação de "trabalho" é um dos pilares de sustentação da relação niniotaginibotagi/niyolola. Os Terena teriam a obrigação moral de cumprir uma espécie de código de honra: “[n]ão podia $[\mathrm{m}]$ fugir porque eles tinham uma tarefa a fazer".

Podemos depreender, ainda do testemunho de Martinho, que há uma contrapartida às obrigações dos Terena e Kinikinau. Segundo ele, os agricultores tinham a tarefa de plantar e os Kadiwéu a de comercializar entre eles ou "lá pelo rio Paraguai" tudo o que conseguissem. Mais uma vez, esse acordo lembra muito aquele

\footnotetext{
${ }^{32}$ É comum encontrar fala dos capitães e seus cativos referindo-se à parte dos nobres como patrícios, termo que geralmente se refere aos membros da nobreza da Roma antiga e àqueles que tem atitudes distintas, de aristocrata. O uso desses termos, assim como "nobre" e "cativo" indica a adoção de um vocabulário que lhes foi aplicado ao longo dos séculos por agentes coloniais e antropólogos, adoção esta que, ainda que tenha sido imposta, nunca foi efetuada de maneira impensada pelos Kadiwéu, como veremos adiante.
} 
descrito pelos documentos históricos, em que os Eyiguayegui trocavam os produtos agrícolas guaná pelas manufaturas dos europeus. A vocação de "comerciantes" dos Eyiguayegui aparece também nas descrições coletadas por Susnik, quando esta afirma que os senhores deixavam seus "escravos" trabalharem no forte Bourbon para ficarem livres "para fazerem alianças e trocas" com os portugueses (1971: 82).

Além de se ocuparem com os "negócios", a festa e a guerra, os niniotagi realizavam muitas outras tarefas. Segundo a documentação colonial, os "capitães" - que pareciam não fazer outra coisa senão estar em guerras ${ }^{33}$ - ocupavam-se também com as expedições de caça, com a prataria, a confecção de lanças e flechas, a construção de canoas, a preparação dos couros de cervos, veados e gado ${ }^{34}$ e a coleta de carandás, palmitos e mel ${ }^{35}$. Além disso, eram descritos como exímios veterinários pois cuidavam sempre do gado, das ovelhas e dos cavalos. Estes últimos, aliás, eram centrais tanto nas expedições guerreiras quanto dentro das tolderias - de acordo com Sánchez-Labrador, os (nobres) donos dos cavalos conheciam “[...] las enfermidades de sus caballos mejor que las suyas próprias”, e lhes direcionavam o melhor dos cuidados, gastando muito de seu tempo com eles ${ }^{36}$. A relação dos "senhores" com seus cavalos era (e continua sendo) tão próxima que a antropóloga Branislava Susnik chegou a falar sobre a possibilidade de uma "crise étnica" eyiguayegui nos fins do século XVIII, quando os paraguaios tentaram colocar em prática um plano de "desequestrização" daqueles índios, visando diminuir seu poder bélico: segundo Susnik (1972: 91), os aristocratas eyiguayegui não podiam se ver sem seus cavalos, correndo o risco de virarem "escravos" ou, em língua eyiguayegui, nibotagi.

A "preguiça” eyiguayegui narrada pelas fontes e apresentada na Abertura, nesse sentido, não se refere à falta absoluta de afazeres por parte dos "senhores". Na realidade, a acusação de que a aristocracia vivia em um "eterno domingo" parece se ancorar não na ausência de atividades, mas em sua não ocupação com certas atividades. Como afirmei acima, a definição dos nobres está diretamente ligada àquela dos escravos: segundo as descrições, o que um fazia o outro não fazia. O termo nibotagi é um exemplo disso. Mesmo que ele tenha sido muitas vezes traduzido por "escravo" ou “cativo”, seu significado exato não é conhecido. A interpretação mais razoável parece ser a de Susnik (1972: 67), que define aqueles reconhecidos como nibotagi não por si, mas em relação àqueles que não se encaixam nessa categoria, de maneira parecida com a

\footnotetext{
33 Schmidel $[1602]: 79$.

${ }^{34}$ Sánchez-Labrador [1770-1776], v. I:297.

${ }^{35}$ Rodrigues do Prado 1795:33.

${ }^{36}$ Sánchez-Labrador [1770-1776], v. I:298.
} 
dupla niyolola-oquilidi. Segundo a antropóloga, o termo nibotagi significava "os que trabalham” e se referia àqueles que, em oposição ao "hombre eyiguayegui', el hombre con lanza, guerrero y cazador", eram conhecidos como homens "sin lanza, el siervo; a estos nibotagi, hombres y mujeres, correspondía todo el trabajo”. Ou seja, os niniotagi eram definidos por não fazerem as atividades das quais se ocupavam os nibotagi pois, como já escreveu Susnik (1972: 67), “[c]iertos trabajos de por sí indicaban luego el status de nibotagi; por esta razón, todos los comunes ${ }^{37}$ poseían dos o más 'nibotagi' para no caer en la vergüenza social del trabajo”.

Ainda que estivesse se referindo à suposta vergonha que os niniotagi sentiriam na realização de atividades consideradas por ela "inferiores”, Susnik parece ter acertado ao usar o termo "vergonha". Muito encontrada na literatura sobre os Jê, a noção de "vergonha" se refere, naquele contexto, à observância de certos protocolos de comportamento que acabam por introduzir e manter distâncias entre recém-casados, sogros e genros e amigos formais, mas não só: segundo Coelho de Souza (2004: 30), a pertinência da "vergonha” ultrapassa largamente o campo das relações entre afins. Entre os Krahô, por exemplo, "denota timidez, reserva, autocontrole, observância da etiqueta, distância social, desempenho de papéis sociais" em diversos níveis ${ }^{38}$. Ainda que essa não tenha sido a intenção de Susnik, sugiro ser possível ler a "vergonha" dos nobres eyiguayegui em uma chave parecida com aquela dos jê, podendo ser entendida como um acatamento a certas normas de comportamento que marcam distinções entre estatutos diversos, recorrentemente construídos pela observação cotidiana desses protocolos 39 .

Como afirmei acima, a "aristocracia" eyiguayegui parecia se distinguir por seu "porte específico, comedimento e boa educação". Todas essas características, por sua vez, parecem constituir essa "vergonha" ameríndia, que parecem ser, não apenas entre os Eyiguayegui, o maior distintivo de classes mais "prestigiosas"; entre os Ramkokamekra, por exemplo, existem grupos de pessoas que são mais suscetíveis à "vergonha”: segundo Coelho de Souza (2004: 31), os indivíduos da classe dos hamren, constituído por pessoas que ocupam certas posições de prestígio, têm muito pahâm (vergonha) em relação a outras classes. Uma comparação entre as divisões de tarefas eyiguayegui e os escritos sobre o decoro entre vários grupos jê poderia indicar vários

\footnotetext{
${ }^{37}$ Como afirmado, ao descrever as partes eyiguayegui, muitos autores descrevem aquela dos comuns, que não seriam nem nibotagi nem nibotagi. Porém, como se depreende da citação, mesmo não sendo nobres eles fazem de tudo para não ter que se ocupar com tarefas de nibotagi.

${ }^{38}$ Carneiro da Cunha (1978:123).

${ }^{39}$ Ver, por exemplo, Melatti (1979), Seeger (1981) e Coelho de Souza (2004).
} 
caminhos de análise, o que demandaria um esforço que não pode ser feito aqui. Sugiro apenas que se entendermos a "vergonha" dos niniotagi em se ocupar com determinadas tarefas não como um descrédito às atribuições dos nibotagi, mas como um respeito a certos protocolos de comportamento que constroem e mantêm determinadas distâncias, veremos como os diferentes estatutos e, portanto, diferentes pessoas, estavam sendo construídas de acordo com suas atribuições, ou melhor, se construíam na adoção do comportamento condizente com sua posição.

Aliás, a oposição niniotagi/nibotagi não era a única a ser construída por este decoro ou código de honra: as relações entre homens e mulheres também pareciam seguir estes protocolos, que foram interpretados pelos autores das fontes históricas de maneira parecida com a oposição entre "senhores" e "escravos". Se, de um lado, os homens eram recorrentemente colocados pelas fontes no âmbito público e político, as mulheres eram descritas no domínio do particular e do doméstico, caso nada raro nas descrições e análises americanistas, que repetem tais correlações como se nelas houvesse algo de universal, transcultural ou natural. Vejamos as tarefas consideradas femininas.

\subsubsection{Escravidão como essência feminina}

As mulheres cativas, quando não são descritas como "concubinas" de seus donos (assunto ao qual voltaremos no capítulo seguinte), são retratadas realizando as mesmas atividades dos cativos homens. As mulheres "nobres", por sua vez, são descritas em uma clara oposição aos "senhores": de acordo com as fontes, ao mesmo tempo em que ambos compartilhavam o "sangue nobre", suas tarefas eram diametralmente opostas. Em contraposição a seus maridos, pais e irmãos - ocupados, do ponto de vista dos europeus que aportaram no Chaco, com atividades políticas como a guerra e as reuniões de caciques - as “donas” pareciam se reduzir ao espaço doméstico: elas cozinhavam ${ }^{40}$, teciam casacos, camisas, ponchos da lã das ovelhas, colhiam cocos, feijões, frutas e raízes ${ }^{41}$, faziam as esteiras, as louças, potes e panelas ${ }^{42}$. Acima de tudo, elas são descritas fazendo as pinturas corporais e tirando todos os pelos - sobrancelhas e pestanas - dos próprios rostos e dos seus maridos, filha/os e cativa/os, em um processo que parecia levar longas horas ${ }^{43}$. A distinção entre as atribuições da nobreza

\footnotetext{
40 Schmidel ([1602]:79).

${ }^{41}$ Sánchez-Labrador ([1770-1776], v. I :297).

${ }^{42}$ Rodrigues do Prado (1795:33).

43 Almeida Serra (1850:355).
} 
feminina e masculina culminou em uma oposição que subsiste até hoje nas análises antropológicas e historiográficas: aquela entra a arte e a guerra ${ }^{44}$.

Essa "divisão sexual do trabalho" descrita pelas fontes e pela literatura atual não traz nenhuma grande novidade para a etnologia. Ela é geralmente considerada a primeira e mais simples forma de organização social, à qual vem se sobrepor outros tipos de diferenciação, como as distinções "rituais", de classe, etc. Mas é importante notar que, no caso dos Eyiguayegui, praticamente todas as atividades consideradas femininas são compartilhadas pelos nibotagi (com exceção da "arte nobre”, ou seja, as pinturas corporais, preparação do corpo e da cerâmica). As fontes muitas vezes nos confundem ao descrever as atividades dos "escravos" ou das mulheres nobres, e a sensação é a de que os próprios autores se atrapalham na categorização dessas atribuições.

É o caso da tecelagem, por exemplo. Em alguns momentos, ela é descrita como uma tarefa das mulheres nobres e, em outros, diz-se que as verdadeiras mestras nesta técnica pareciam ser não as donas eyiguayegui, e sim as mulheres guaná, que eram “[...] las principales hilanderas y tejedoras de sus bellas mantas" ${ }^{45}$. De fato, os ponchos de lã por elas confeccionados eram o principal produto oferecido pelos Guaná aos Eyiguayegui nas visitas realizadas entre suas tolderias, além de figurarem como o principal presente oferecido pelo anfitrião da festa de criação do cacique às pessoas que têm papel de destaque na cerimônia ${ }^{46}$.

Essa confusão revela dois pontos pouco explorados na literatura chaquenha. Primeiro, o fato de que as capitãs guaná (denominadas "servas" por muitas fontes) vinham para as tolderias como mulheres nobres, tanto que eram confundidas com as “donas” eyiguayegui. Segundo, a relação aparentemente fácil entre mulheres - ainda que nobres - e "escravos", que acabava fazendo com as capitãs guaná fossem confundidas com "servas" e as "donas" eyiguayegui fossem equalizadas a "escravas". Essa conexão, por sua vez, era comprovada pelas fontes na similaridade das atribuições de mulheres e nibotagi: ambos cozinhavam, carregavam os pertences nas mudanças de tolderias e "acompanhavam” as expedições guerreiras. É interessante salientar que essa relação entre feminilidade e escravidão não é exclusiva dos escritos sobre os

\footnotetext{
${ }_{44}$ Senhoras da arte, senhores da guerra: a frase, que dá título a duas coletâneas de artigos sobre os Kadiwéu (José da Silva 2011; José da Silva \& Kok 2014), parece também veicular a ideia de uma complementaridade entre duas unidades - feminino e masculino - que não se entremeiam. Essa discussão será aprofundada no próximo capítulo.

45 Aguirre 1793:478.

46 A circulação dessas mantas e ponchos de algodão e lã, que pareciam movimentar uma rede de comércio chaquenho, parece ser um grande tema para pesquisas posteriores.
} 
Eyiguayegui: a antropóloga Beatriz Vitar (2001: 239, tradução minha), por exemplo, fala da criação, pelas fontes jesuíticas, de uma "imagem subordinada e servil" das mulheres indígenas chaquenhas. Segundo o missionário Pedro Lozano (1873: 76) citado pela autora, por exemplo, as mulheres guaicurú seriam "como escravas perpétuas de seus maridos”, ainda que levassem com eles uma vida conjugal.

Além disso, de maneira similar àquela dos nibotagi, as tarefas da maioria das mulheres também são retratadas como "árduas". Observando a distribuição das tarefas nas tolderias eyiguayegui, por exemplo, Émile Rivasseau (1936:72) escreve que "em todas as tribos indianas" é normal que se atribua às mulheres "os trabalhos mais duros e mais penosos", julgando normal que, nessas circunstâncias, elas sejam consideradas “ainda mais ou menos como escrava[s]”. Essa sobreposição da distinção entre "nobres" e "escravos" à divisão sexual do trabalho parece ser consenso nas fontes analisadas. E não apenas às fontes: Fernando Santos-Granero chega a afirmar, sobre os trabalhos realizados pelos "escravos" ameríndios, que os "cativos homens eram frequentemente obrigados a executar tarefas menores, que eram consideradas dominio das mulheres" 47 (Santos-Granero 2009:128, tradução e grifos meus), o que seria prova do controle de seus capitães sobre eles.

E não apenas a divisão sexual das tarefas é uma velha conhecida da Antropologia: mesmo as funções definidas como masculinas e femininas são apresentadas como universais - de um lado os homens caçam e guerreiam e, de outro, as mulheres cozinham, cuidam das crianças, tecem, fazem cerâmica... As narrativas dos cronistas constroem um mundo muito parecido com o dos Aché-Guayaki de Pierre Clastres (2003:122), no qual existe, segundo o autor, "um espaço masculino e um espaço feminino, respectivamente definidos pela floresta onde os homens caçam e pelo acampamento onde reinam as mulheres". Ali, tarefas de homens e mulheres definiriam a própria existência masculina - "que só se torna autêntica quando realizada" na caça e feminina - definida pelas funções da maternidade e do casamento ${ }^{48}$. Do mesmo modo os autores dos documentos históricos definem homens e mulheres, nibotagi e niniotagi. Em seus escritos há uma relação direta entre o que as pessoas fazem e o que elas são: aos homens nobres o movimento e a floresta; às mulheres e "escravos" o sedentarismo e as tolderias.

\footnotetext{
47 "Male captives were frequently obliged to perform menial tasks that were considered to be in the women’s domain” (Santos-Granero 2009:128).

${ }^{48}$ Clastres (2003:123).
} 
Essa relação parecia tão óbvia às fontes que quando uma pessoa não realizava a função que lhe era supostamente designada ela parecia perder "a sua própria natureza e sua substância lhe escapa[va]"49. Quando uma mulher ia para guerra, um nobre cozinhava e um nibotagi caçava, por exemplo, os escritos enchiam-se de espanto.

É o caso dos cudina que, segundo Almeida Serra (1850:358), faziam os "mesmos trabalhos" que as mulheres. Ele(a)s eram descrito(a)s como "homens que affecta[va $] \mathrm{m}$ todos os modos das mulheres; vest[ia $] \mathrm{m}$-se como ellas, ocupa[va $] \mathrm{m}$-se em fiar, tecer, fazer panelas \&c" ${ }^{50}$, vistos como verdadeiras aberrações, "nefandos demônios" ${ }^{51}$. O fato de esses homens terem assumido - assim como Krembegi, índio guayaki apresentado por P. Clastres (2003: 127) - "até as últimas consequências sua condição de home[ns] não-caçador[es]", abandonando o arco para viverem "como mulheres", era para as fontes inconcebível. Aliás, é interessante perceber o paralelo possível entre os cudinas eyiguayegui e os two-spirit norte-americanos (por muito tempo conhecidos como berdache), aquelas pessoas que foram muitas vezes denominadas como "travestis" ou "homossexuais". Nos dois casos as fontes históricas localizam a transformação destes "homens" em "mulheres" (e, no caso da América do Norte, também de "mulheres" em "homens") no momento em que ele(a)s passam a realizar tarefas consideradas femininas. "Entre os Yurok, por exemplo, um homem jovem se torna wergern [twospirit] quando começa a tecer cestas" e, depois deste momento, ele logo passa a "se vestir como mulher" (Désy 1993:19). Também entre os Pima, "um menino que mostra uma predileção por brincar com cestas será 'como uma menina”" (Désy 1993:19). A capacidade de transformação de gênero contida nessas atribuições, porém, não será discutida no presente trabalho. O importante aqui é salientar que essas tarefas não apenas não fazem parte de uma essência de homens e mulheres, "escravos" e "senhores", como também têm a capacidade de operar transformações corporais, como acontece nos casos - muito narrados nos documentos - de nibotagi que viravam "caciques" por conta de seus grandes feitos guerreiros. Cativos que se tornavam guerreiros, aliás, parecem ser entendidos pelas fontes como pessoas em um estado de transição da "escravidão" para a "nobreza”, sendo alocados na camada dos "comuns".

Parece haver uma multiplicidade de pontos de vista que se atravessam e são expressados pelas fontes. Ainda que tentem sustentar a afirmação de que as atribuições

\footnotetext{
${ }^{49}$ A formulação é Clastres (2003:125), ainda a respeito dos Aché-Guayaki.

${ }^{50}$ Rodrigues do Prado (1795:32).

${ }^{51}$ Almeida Serra (1850:358).
} 
dos niniotagi e dos nibotagi, dos homens e das mulheres ${ }^{52}$ eram fruto de sua essência (que destinaria as mulheres, por exemplo, aos trabalhos domésticos e os "escravos" às tarefas ditas menores), os autores das fontes acabam por deixar transparecer movimentos contrários a essa suposta "natureza". O que seus dados permitem entrever é que havia mesmo algo como um "código de honra" (ou decoro) que demarcava contextualmente certas distâncias; essas distâncias, por sua vez, pareciam se exprimir também nas diferentes tarefas realizadas pelas pessoas. Ou seja, niniotagi e nibotagi, homens e mulheres, eram realmente distintos por suas atividades, mas não por conta de sua essência, e é por isso que as fontes narram movimentos de transição (ou transformação) entre um estatuto e outro. Não sendo algo "natural" e podendo ser produzido e reafirmado por meio do comportamento, esses estatutos não eram estanques, ou matéria do ser, e sim transformacionais, questão do devir.

Os cronistas, viajantes e missionários autores das fontes, porém, acabaram por interpretar as diferentes atribuições não apenas como distintas - como elas pareciam ser lidas pelos índios - mas também como desiguais ${ }^{53}$, definindo as categorias que povoavam as tolderias eyiguayegui por meio do "trabalho" executado pelas pessoas e afirmando serem algumas delas inferiores e outras superiores. Mas a análise atenta desses documentos mostra que em nenhum momento os índios dizem não realizar tais tarefas por serem elas inferiores a seu status. Se por um lado os dados trazidos por essas fontes permitem ver que as tarefas eram diferentes entre pessoas distintas, por outro eles não nos possibilitam afirmar que essa diferença é concebida em termos de superioridade e inferioridade. Como demonstro as seguir, essa relação entre atribuição e hierarquia se explica pela noção de "trabalho" que permeia grande parte das descrições e análises antropológicas sobre os Eyiguayegui.

\subsection{Sobre o trabalho: $o$ que se fazia nas tolderias}

Ao descrever uma de suas viagens exploratórias realizadas Chaco adentro, o soldado alemão Ulrich Schmidel escreve:

De allí marchamos otras siete jornadas, hasta que llegamos a una nación que se llama Mbaya. Estos forman un gran pueblo, con vasallos que deben pescar y labrar los campos y hacer aquello que sus

\footnotetext{
52 Sobre a reprodução de um "esquema divisorio de las funciones y relaciones de género, conforme a la mentalidad patriarcal y al modelo de organización social” ocidental, que fazia os jesuítas procurarem “ordenar la realidad indígena según los patrones culturales europeos [y] bajo una óptica 'androcentrista”, ver Vitar (2001:60; 2015: 224).

${ }^{53}$ No sentido da "desigualdade social" discutida anteriormente.
} 
señores les manden, lo mismo que allá, en Alemania, los labriegos sometidos a un señor (Schmidel [1602]:78).

O excerto acima, retirado do diário de Schmidel, é de extrema importância na literatura sobre o Chaco: é aí que se realiza, pela primeira vez, a comparação entre as relações oquilidi -niyolola e aquelas entre senhores feudais e servos europeus. Para além de realizar essa equiparação, o explorador efetua também uma aproximação entre as relações de trabalho que as sustentam. Como afirmado, essa comparação só é possível no momento em que o alemão percebe uma diferença naquilo que uns e outros fazem: de um lado, os niyolola exerceriam o que ele denomina "trabalho" e, de outro, os oquilidi não fariam “outra coisa senão estar em guerras”. O explorador equipara, então, as tarefas realizadas pelos Guaná ao trabalho dos lavradores alemães, entendido como resultado de uma situação de sujeição, e a guerra eyiguayegui àquela da aristocracia europeia.

Essa comparação, comum na literatura regional, parece se fundamentar em dois elementos que serão aprofundados nesta seção. Em primeiro lugar, a própria definição de trabalho efetuada pelos autores das fontes já fazia com que as diferentes atribuições fossem dispostas em uma gradação hierárquica: o trabalho era visto, na maior parte das vezes, como signo de inferioridade e acabava por ser inserido na oposição entre público e doméstico, em que o "público" tendia a ser visto como mais importante. Além disso, há uma constante oposição entre o trabalho como tortura e outras atividades - a festa e a guerra, por exemplo - como prazer. Em segundo lugar está a visão simplificadora e tendenciosa que viajantes, missionários e militares dirigiam às populações chaquenhas e ameríndias, que acabava por fazê-los desacreditar de sua nobreza (ainda que as afirmassem) e considerá-los todos preguiçosos. Logicamente, essa visão não era despretensiosa: ela se encaixava em um contexto de colonização em que o trabalho era tido como via de civilização das sociedades ameríndias, consideradas "selvagens".

A intenção desta seção é a de apresentar alguns modos de pensar a noção de “trabalho". Essas formas são indissociáveis e não estão, necessariamente, dispostas em uma linha do tempo linear: algumas delas, aliás, parecem perdurar até os dias de hoje, como veremos. É importante pontuar que não pretendo aqui fazer uma arqueologia da noção de trabalho, nem de esgotar todos os significados que ela pode trazer. O verbete dedicado ao termo no dicionário Houaiss, por exemplo, tem mais de vinte acepções, que não poderiam ser destrinchadas no momento. As próximas linhas têm como objetivo, portanto, iluminar algumas perspectivas sobre o "trabalho" que podem fazer enxergar alguns pilares que sustentam a construção teórica da "hierarquia" eyiguayegui. 


\subsubsection{Doméstico e público; suplício e prazer}

As palavras de Schmidel supracitadas deixam claro que o alemão considerava o trabalho guaná uma obrigação, quase uma sentença: o explorador afirma, com todas as letras, que a população chaquenha era constituída de "vassalos" que deviam "pescar e lavrar os campos e fazer aquilo que seus senhores" lhes mandassem. Essa acepção do vocábulo "trabalho" se aproxima muito da origem mesma da palavra, o verbo em latim tripaliare - "torturar" - associado ao instrumento de tortura tripalium, muito utilizado pela Igreja Católica na Idade Média ${ }^{54}$. Até o século XII, a palavra "trabalho" significava uma experiência dolorosa. Dessa ideia inicial de "sofrer" ela se transformou gradualmente na de "esforçar-se", "lutar" e, por fim, "trabalhar". Foi apenas entre os séculos XV e XVI - quando os escritos europeus sobre os povos chaquenhos começaram a surgir - que ela começou a ser utilizada em contextos mais parecidos com os atuais ${ }^{55}$.

A noção de trabalho como uma tortura está ancorada na ideia de que uns trabalham para outros e, mais do que isso, não trabalham porque querem, mas porque são forçados. Mesmo considerando haver um "pacto" entre os oquilidi e os niyolola, Schmidel (e a maioria dos autores das fontes históricas) parte(m) do pressuposto de que, neste contrato, uma das partes é mais forte e pode obrigar a outra a fazer os serviços "menores" em seu lugar. Seguindo essa linha de raciocínio, os lavradores guaná e os "domésticos" cativos, bem como as mulheres (que são frequentemente equiparadas a "escravas"), não teriam escolha e estariam submetidos a certos tipos de tarefa. Aliás, na visão desses autores, se eles pudessem escolher, certamente estariam "se guardando para a guerra" 56 , ou ocupando-se de atividades mais "prazerosas", como as próprias expedições guerreiras, de caça ou de coleta do mel ${ }^{57}$.

A distância que os "nobres" eyiguayegui mantinham do "trabalho" também é explicada pelas fontes em termos próprios às civilizações ocidentais. Nas sociedades europeias pré-Revolução Francesa, por exemplo, as tarefas "menores" e da terra ficavam restritas à maioria da população, constituída de camponeses, artesãos,

\footnotetext{
${ }^{54}$ Cunha (2010: 642).

${ }_{55}$ Para um histórico mais aprofundado do conceito de "trabalho", ver Illich (1973).

${ }_{56}$ Almeida Serra (1850:345).

57 A definição da atividade guerreira como "prazerosa” chega a ser intrigante, levando em consideração todos os esforços a ela dirigidos. Desenvolverei descrições mais detalhadas sobre a guerra no próximo capítulo.
} 
comerciantes, entre outros, que trabalhava para a aristocracia (a quem cabia a guerra, a proteção dos reinos e os bailes) e dos sacerdotes (responsáveis pela soberania espiritual). Assim como pareciam fazer os nobres eyiguayegui (de acordo com os autores das fontes), essas duas últimas classes consideravam o trabalho uma atividade degradante, ao contrário das suas próprias, consideradas enobrecedoras (Enriquez 2014:167).

Antes disso, como se sabe, os cidadãos atenienses também tinham bem pouco interesse pelo trabalho, preferindo se ocupar das questões do "bem comum" e deixar a labuta da terra e da casa para os camponeses e escravos. O cidadão tinha por tarefa atuar pelo bem da democracia, participando das decisões que pudessem afetar a todos, enquanto os não cidadãos ficavam encarregados das tarefas mais vis e particulares (Enriquez 2014:166).

Aliada às ideias de suplício e inferioridade (contrapostas a certas definições de prazer e nobreza), portanto, orbita em torno da noção de "trabalho" a contraposição entre o público e o doméstico, o político e o particular. Está implícita nas obras analisadas a percepção de que os "nobres" eyiguayegui, como os aristocratas europeus e os cidadãos atenienses, deixavam o "trabalho" nas mãos de outrem para se ocupar com problemas de política: as expedições guerreiras, os conselhos de chefes, as festas de construção da chefia... Nas entrelinhas dos documentos encontra-se também a ideia de que os niyolola e os nibotagi- denominados por Azara como "escravos ou domésticos" -, assim como os escravos de Atenas e a plebe europeia, estariam ilhados em suas tarefas "domésticas" no interior dos toldos, alheios às discussões políticas e excluídos dos espaços públicos de decisão.

Essa oposição entre público e doméstico, assim como a ideia de divisão sexual do trabalho, é basilar em diversas teorias antropológicas. Na verdade, essas duas contraposições acabam se transformando uma na outra, visto que geralmente as mulheres são colocadas, como afirmado, no âmbito doméstico e os homens no público. A teoria do britânico Meyer Fortes (1983) é importantíssima para o estabelecimento dessa oposição na história da disciplina: segundo ele, o doméstico seria o lugar da reprodução corporal da sociedade, onde são criadas as novas gerações que dão continuidade a ela. Nesse âmbito estariam as mulheres, ligadas substancialmente e afetivamente a seus filhos e a seu marido. A família e o doméstico aparecem, na obra de Fortes (1983:28), como aquilo que dá forma ao processo natural de reprodução. O que une as famílias entre si e forma a sociedade, segundo o autor, é a instituição da paternidade, que traz para dentro do âmbito doméstico as regras e a autoridade, antes 
inexistentes. A figura masculina e paterna, ligada ao sistema político de regras e leis, faz, em sua teoria, a passagem entre a natureza e a cultura, transformando relações antes naturais em relações institucionalizadas e, portanto, sociais. Nesse sentido, de acordo com Fortes, a política se encontra, na maioria das sociedades não-ocidentais, nos sistemas de descendência que formam grupos não relacionados necessariamente à reprodução "natural”. O domínio doméstico e as mulheres, por sua vez, são relegados a um estado de quase natureza, não interferindo no âmbito da política. Os mesmos pares de opostos surgem nas mais variadas análises americanistas, notadamente desenvolvidos pela reflexão em torno dos dualismos jê, onde pátio-público-culturamasculino são reiteradamente contrapostos a casas-privado-natureza-feminino ${ }^{58}$ (ver por exemplo Turner 1966; Da Matta 1976).

Os autores das fontes analisadas também compartilham da noção "de que a unidade doméstica - a família biológica encarregada de reproduzir e socializar novos membros da sociedade - se opõe à entidade pública - a estrutura dominadora das relações e aliança que é a sociedade [...]” ${ }^{59}$. Por conta de sua importância considerada quase nula para a política eyiguayegui, os nibotagi, niyolola e mulheres parecem constituir um nível inferior, representando uma "categoria particular de interesses" - o das famílias - em contraposição à superioridade dos interesses universais do espaço público, masculino e aristocrata. Esse movimento de hierarquização entre os espaços público e doméstico, por sua vez, acaba por levar consigo os tipos de tarefa relacionados a cada domínio: os afazeres domésticos são vistos como menores ${ }^{60}$ e as atividades ligadas ao "bem comum" são valorizadas. Não por acaso, ao descrever as atividades dos "escravos" e membros das "populações tributárias", o antropólogo Santos-Granero (2009) as define como chores. Em inglês, a palavra se refere tanto à "pequenez" e caráter entediante de algumas atividades, vistas como obrigação, quanto à sua localização no âmbito doméstico. Lavar a louça e varrer a casa - atividades que os senhores kadiwéu delegam a outros -, por exemplo, são atividades denominadas chores.

A noção de "trabalho" como uma tarefa "menor" e "árdua" em oposição a atividades menos custosas e superiores, explica, portanto, a comparação entre os índios cavaleiros e a nobreza europeia realizada pelas fontes: ambos se recusariam, na versão da maior parte delas, a desempenhar certas tarefas temendo manchar sua nobreza.

\footnotetext{
58 Para uma crítica à associação efetuada a priori entre domínio doméstico ao "particular" nas sociedades jê, ver Lea (1994; 2012).

${ }_{59}$ Ortner (1979:108).

${ }^{60}$ De acordo com Santos-Granero, aos cativos eram atribuídas as atividades "mais pesadas, sujas e de menor status” (Santos-Granero 2009:127, tradução minha).
} 
Porém, a acusação - presente nos mesmos documentos e apresentada na Abertura - de que os capitães eyiguayegui eram preguiçosos fica, ainda, sem explicação. Se, de acordo com a visão corrente, o "trabalho" era degradante e os Eyiguayegui podiam (ou deviam) dele se abster, tornando-se "nobres", porque os cronistas insistiam em condená-los por essa escolha, julgando-os indolentes?

\subsection{2 "Eterno domingo"?}

Se Deus quiser, um dia eu quero ser índio Viver pelado, pintado de verde num eterno domingo

Ser um bicho preguiça e espantar turista E tomar banho de sol, banho de sol, banho de sol, sol

“Baila comigo", Rita Lee

A análise das fontes parece mostrar que, mesmo descrevendo os niniotagi como nobres, os autores dos documentos não levavam realmente a sério sua nobreza. Escreve Sánchez-Labrador ([1770-1776], v. I: 68): “causa risa oír a los fanfarrones Bayás, llenos de vanidad", exaltando "su valor hasta las estrellas" e confiando "con su insolencia" serem superiores a todas as nações. Esse escárnio da aristocracia eyiguayegui não é exclusivo do missionário: o capitão Almeida Serra (1845: 204) zomba em diversos momentos do que chama de "afetada condescendência" e "ridícula altivez" dos niniotagi. A “vaidosa e ridícula soberba com que se considera[va $] \mathrm{m}$ uma nação de heróes e de fidalgos"61 era reiteradamente desacreditada, a ponto de o militar espanhol Aguirre se espantar com o fato de os Eyiguayegui não terem ainda se convencido, à sua época, de que "fuesen inferiores á los españoles", considerando-se sem exceção "la nación más noble y superior de todas las indianas"62. Por mais que operassem uma divisão entre "nobres", "plebeus" e "escravos", portanto, a hipótese da existência de uma aristocracia eyiguayegui nunca foi levada até as últimas consequências pelos autores das fontes. Para supor que os nobres selvagens deviam trabalhar como os não-nobres europeus era preciso, de algum modo, não levar a sério sua "nobreza".

É curioso perceber que esse descrédito à nobreza eyiguayegui não aconteceu com as "aristocracias" das terras altas sul-americanas, onde o "Império" inca, aparentemente "provido de um aparato logístico estatal, sua burocracia e sua casta de membros", em conjunto com seus supostos "fenômenos sociológicos da hierarquia, da

\footnotetext{
${ }^{61}$ Almeida Serra (1850: 378, grifos meus).

62 Aguirre (1793: 474).
} 
coerção e da complexidade" 63 foram logo reconhecidos pelos conquistadores como uma expressão do Estado, ou seja, de uma forma minimamente inteligível de política. Se os povos indígenas das terras baixas eram considerados "sem lei e sem rei" ${ }^{4}$, sendo consequentemente entendidos como populações bárbaras, as altas civilizações andinas pareciam ter tanto lei quanto rei, sendo comparadas ainda mais livremente às nações europeias. A nobreza dos incas e dos toltecas era levada extremamente a sério, ao contrário da aristocracia eyiguayegui, descrita na maior parte das vezes como fajuta.

Para além desse descrédito à aristocracia eyiguayegui, esbarramos aqui em outra questão: a diminuição forçada das guerras, consequência das políticas coloniais, parece ter deixado, com o passar do tempo, os nobres guerreiros realmente “desocupados”. Segundo Darcy Ribeiro (1980a: 65) a situação dos homens jovens e adultos kadiwéu na época de sua visita só podia ser explicada "pelo desaparecimento do guerreiro, sem sua completa substituição”. Segundo o antropólogo, esses guerreiros inativos passavam seus dias apenas "cuidando de uns poucos cavalos e bois, em caçadas extemporâneas ou em andanças pelas fazendas vizinhas", ou seja, sem trazer grandes rendimentos ao grupo. De acordo com Ribeiro, “[t]udo funciona[va $]$ nas aldeias Kadiwéu, como se aqueles jovens vigorosos estivessem reservando forças e recebendo estímulos para uma ação guerreira já planejada”. A situação, à época do campo de Ribeiro (entre 1947 e 1948), seria "quase a mesma" de antigamente, "quando aos homens válidos só cabia a atividade guerreira”.

É interessante notar que todas as atividades citadas pelo autor, além da guerra, eram distintivas dos antigos niniotagi, como descrito acima. De maneira similar, os funcionários do Serviço de Proteção ao Índio também consideravam os guerreiros da época de Ribeiro preguiçosos ${ }^{65}$, assim como escreviam os autores de nossas fontes: por não trazerem nenhum rendimento, suas atribuições não eram consideradas pelos agentes governamentais e nem pelas fontes como "trabalho". A “altivez e negação ao trabalho"66 dos nobres eyiguayegui continuava, portanto, a ser censurada, ainda que o trabalho fosse considerado inferior.

No mais, segundo as fontes, não eram só os niniotagi que não trabalhavam tanto quanto os europeus julgavam necessário: até mesmo aqueles que se ocupavam dos

\footnotetext{
63 A citação é de Cavalcanti-Schiel (2014: 255-6). Sobre a divisão efetuada pelos modelos analíticos da etnologia sul-americana entre as terras baixas e altas do subcontinente, ver Viveiros de Castro (2002: 319-44), Clastres (2003), Drago (2012) e Cavalcanti Schiel (2014).

${ }^{64}$ Expressão famosa presente no documento "Carta a el-Rei Dom Manuel sobre o achamento do Brasil", escrito pelo escrivão português Pero Vaz de Caminha, escrivão português em $1^{\circ}$ de maio de 1.500 .

${ }^{65}$ Ribeiro (1980a: 66).

${ }^{66}$ Almeida Serra (1849:204-5).
} 
afazeres "menores" não pareciam perder muito tempo com eles. “ $[\mathrm{M}]$ ientras sus amos duermen, [os cativos] se embriagan ó hacen otras cosas", narra o admirado SánchezLabrador ${ }^{67}$. A desconcertante ausência de trabalho daqueles cuja função era justamente trabalhar era explicada nas fontes como consequência da escassa autoridade dos "senhores": segundo as fontes, os "nobres" nunca obrigavam os nibotagi a nenhum serviço $^{68}$ e seus "donos" lhes dirigiam "bem poucas ordens" 69 . Como escreveu P. Clastres (2003:211), aos olhos dos exploradores, militares e missionários, aquele se tratava de um povo "que ignorava deliberadamente que é preciso ganhar o pão com o suor do próprio rosto" - não muito diferente de muitas outras populações indígenas americanas, diga-se de passagem.

Os Eyiguayegui e seus "escravos" não foram os únicos considerados pelos europeus preguiçosos: todos os índios o foram. E aqui se apresenta outro indício importante para a análise. Essa acusação está presente não apenas nos documentos históricos chaquenhos, mas nas fontes dos mais variados contextos etnográficos. Muitas das missões jesuíticas empreendidas até o século XVIII - inclusive em terras chaquenhas -, por exemplo, fundamentavam-se na premissa de que o caminho de elevação daqueles "bárbaros" estava na fé, na disciplina e no trabalho. A "reserva da mão de obra"7o realizada pelos jesuítas e justificada por essa premissa, por sua vez, nunca foi abertamente escravocrata: sua intenção era criar "homens livres" que pudessem servir ao regime colonial de diversas maneiras, desde o cultivo das roças até a participação em expedições guerreiras (Perrone-Moisés 1992; Sztutman 2012). Mesmo com o passar do tempo e com a gradual perda de importância da conversão para o projeto colonial, o trabalho continuou a ser base de sua política: aos poucos, o que se desejava passou a ser "não tanto a transformação em cristão, mas a transformação em vassalo útil” à Coroa (Perrone-Moisés 1992: 32). Grande parte dos desentendimentos entre populações indígenas e órgãos governamentais até hoje, digase de passagem, tem origem na concepção de trabalho. Como demonstrado na descrição de Ribeiro (1980a), os funcionários do SPI continuavam a chamar os índios kadiwéu de preguiçosos até não muito tempo atrás.

Essa questão de suma importância, porém, parece nunca ter sido devidamente enfrentada e desenvolvê-la aqui nos levaria mais longe do que interessa ao presente

\footnotetext{
${ }^{67}$ Sánchez-Labrador ([1770-1776, v. I]:251).

68 Taunay (1840:21).

${ }^{69}$ Azara (1809:56).

70 Segundo Sztutman (2012: 162), a política dos aldeamentos jesuítas colocava em prática objetivos basilares "do projeto colonial, visto que unia diferentes sentidos da conquista: a conversão (cooptação de almas), a ocupação (cooptação de territórios) e a reserva de mão de obra (cooptação de corpos)”.
} 
trabalho. Basta dizer que o julgamento dos povos indígenas como "preguiçosos" parece estar ligado a uma quebra da expectativa dos colonizadores, que viam o trabalho (em conjunto com a conversão ao cristianismo) como via de civilização dos "selvagens".

O "eterno domingo" em que os índios sul-americanos foram acusados de viver, nesse sentido, dizia respeito ao desencontro - para falar de maneira sutil - entre as noções de atividade, atribuição e trabalho de ameríndios e colonizadores. Pois, como mostram as fontes, além de não quererem trabalhar tanto quanto os europeus achavam necessário, os índios não precisavam efetivamente de tantas horas de atividade produtiva e mesmo o "trabalho" dos nibotagi e niyolola parecia às vezes não ser tão indispensável. Pelo menos é o que demonstra Almeida Serra (1845:204-5) ao discutir a "ridícula altivez e negação ao trabalho [dos Eyiguayegui], [que] lhes faz[ia] desprezar as fadigas da agricultura". Segundo ele, os índios cavaleiros "com efeito não necessita[va]m” do trabalho agrícola "para viverem longos anos, robustos e fartos", podendo encontrar "no Rio Paraguay e nos seus amplíssimos campos sempre provida dispensa”. As expedições de caça e pesca, por sua vez, não aconteciam sempre, obedecendo, como apresentado no capítulo anterior, certas regularidades sazonais ${ }^{71}$ mal compreendidas pelas fontes. Aquilo a que damos o nome de "trabalho" agricultura, afazeres domésticos e tarefas braçais - ocupava uma pequena parte do dia das pessoas. Muitos documentos trazem o desconsolo de seus autores, que não entendiam por que os homens jovens - tanto "nobres" quanto "escravos" - insistiam em passar o dia inteiro "sem fazer nada", se "guardando para a guerra" e dizendo que "a mocidade é para se ficar com as mulheres"72.

Esse pouco gosto por aquilo que entendemos como "trabalho" - que agora vemos ser compartilhado por capitães, nibotagi e niyolola - não é, como veremos, uma particularidade chaquenha, assim como a pecha de "preguiçosos" que lhes foi injustamente atribuída. Aliás, antropólogos como Marshall Sahlins e Pierre Clastres já haviam se debruçados sobre a questão partindo de outros contextos etnográficos. Por meio de suas contribuições, podemos repensar a noção de poder ligada ao lugar das atribuições entre os Eyiguayegui e outras sociedades indígenas. Como demonstro na próxima seção, suas análises apresentam outras formas de pensar a (contra-)economia, tirando do centro da noção de "atividade produtiva" ideias de exploração, acumulação, subsistência e a polarização entre a labuta e o prazer.

${ }^{71}$ Rodrigues do Prado (1975:33).

72 Almeida Serra (1850:354). 
2.2.3 Da economia contra o trabalho

A "preguiça” encontrada entre os Eyiguayegui é também característica de outros povos denominados "caçadores e coletores", sendo tema de uma rica análise também fundamentada em fontes históricas e dados etnográficos contemporâneos - do antropólogo Marshall Sahlins (1972). Segundo o autor, é possível afirmar que essas populações trabalham muito menos do que nós; elas cumprem "horários de banqueiros"73, de três a cinco horas por dia; sua rotina de trabalho não é contínua, mas intermitente; e suas horas de sono diurno são bem maiores do que as de um operário (dados que poderiam ter sido coletados entre os Eyiguayegui). Ainda assim, não lhes falta nada: ao contrário do que se esperaria, os membros desses grupos não passam fome, não estão desesperados em busca de comida e nem se alimentam apenas das mesmas espécies o ano todo. Na verdade, eles são bem exigentes com sua alimentação, seus pratos são sempre variados e seu consumo energético não deixa nada a desejar. Ao invés de se contentar com sua "mera existência", como por muito tempo antropólogos e economistas afirmaram, os caçadores vivem muito bem. Os dados trazidos por Sahlins mostram que eles conseguem conjugar uma carga menor de trabalho com a satisfação total de suas necessidades - o sonho de qualquer um de nós. Aliás, essas populações não despendem toda a sua força produtiva para manterem-se vivas: elas poderiam muito bem trabalhar mais e aumentar a produção mas, como demonstra o autor, este simplesmente não é o seu interesse.

$\mathrm{Na}$ perspectiva dos autores das fontes (e nossas, no fundo, como mostra Sahlins), a escolha dos "caçadores e coletores" parece disparatada. Olhando para esses povos por meio do "prisma angustiado" da escassez - fundamento da nossa economia -, eles não conseguem entender por que os índios não dedicam mais tempo às atividades produtivas de plantação, pesca e caça, e acabam atribuindo esse comportamento à sua “indolência" e "soberba". Porém, como demonstra o antropólogo norte-americano, a opção dessas populações se deve a uma ideologia não fundada no princípio da escassez. Segundo o autor, na concepção das ciências econômicas ocidentais, os recursos disponíveis - naturais e humanos - são finitos. Para satisfazer os humanos, que tudo querem, é necessário produzir cada vez mais sabendo, entretanto, que nunca se conseguirá satisfazer as vontades de todos. A vontade é infinita e os recursos são escassos. Já na concepção dos povos estudados pelo antropólogo, que se aproximam muito do caso eyiguayegui, os recursos não chegam a ser infinitos mas as necessidades

${ }^{73}$ Sahlins (1972:34). 
das pessoas são muito menores, de modo que os meios não se esgotam e sempre bastarão. Se no primeiro caso as técnicas de produção devem ser continuamente reformuladas para otimizar a (pouca) força de trabalho e disponibilidade de materiais, no segundo as técnicas não se transformam muito porque a força de trabalho, assim como os recursos do meio 74 , "sobram" (Sahlins 1972:4). Em uma concepção o trabalho deve ser explorado o máximo possível e, na outra, só se trabalha quando necessário. As diferentes concepções de economia trazem consigo relações diversas com a atividade.

Há no argumento de Sahlins (1972:33) outro motivo para a recusa da superprodução pelos caçadores: o constante movimento dessas populações que, para se manterem na "abundância", precisam se deslocar em busca de alimentos. O excesso de produtos "supérfluos" - que não servem à subsistência - apenas atrapalharia as andanças recorrentes dos caçadores e coletores. Nesse sentido, ao invés de possuírem uma economia de subsistência, como postulava-se, povos como os Eyiguayegui (considerados muitas vezes "semi-nômades", como afirmado no capítulo anterior) teriam uma economia da abundância fundamentada na movimentação periódica e contenção da acumulação de bens.

Partindo da análise de Sahlins, o francês Pierre Clastres (2003:213) vai mais longe: segundo ele, os caçadores não apenas têm uma concepção diferente de economia. Eles são efetivamente contra a economia (assim como são contra o Estado). De acordo com o etnólogo, é porque as sociedades primitivas negam sua divisão em dominantes e dominados que negam também sua segmentação em patrões e trabalhadores. Pois, para ele, é sempre por causa do poder "que os homens trabalham além de suas necessidades". Ao afastar o surgimento de uma força externa à sociedade - o poder coercitivo -, elas afastam também a exploração do trabalho. Não há, portanto, qualquer motivo que faça com que essas populações produzam mais do que precisam. E mais: para P. Clastres, os coletivos primitivos (o que inclui os ameríndios) são máquinas antiprodutivas que visam o afastamento da acumulação de bens, que só traria a concentração de poder nas mãos de poucos. Na obra do francês, as atividades realizadas pelas pessoas só se tornam trabalho quando uma força externa as utiliza para a acumulação de bens e consequente

\footnotetext{
${ }^{74}$ Aliás, o próprio "meio" não é visto como um depositário de recursos. A etnologia das terras baixas tem mostrado como a "natureza" não é algo dado e alheio à agência humana, como as ciências ocidentais postularam na maior parte das vezes. O "meio" habitado pelos povos ameríndios - e por todos os povos, afinal - são "resultado de milênios de manipulação humana” (Viveiros de Castro 2002: 326) e a relação entre natureza e cultura dessas populações parece ser, em alguns pontos, inversa à nossa: tornou-se famosa a proposição de Viveiros de Castro de que a natureza, entre os índios das Américas, estaria mais próxima daquilo que entendemos por "construído", enquanto a cultura estaria mais próxima do "dado". Sobre a discussão acerca das ontologias dos povos ameríndios e da oposição natureza/cultura, ver Viveiros de Castro (1996; 2002); Descola (1996); Latour (1994).
} 
concentração de poder. Nesse sentido, há uma diferença entre a simples atividade que visa saciar as próprias necessidades e a que se destina a enriquecer os outros. É aí que a simples atividade vira trabalho.

É importante notar que os dados trazidos pelas fontes contrariam, de um lado, suas próprias afirmações e, de outro, a tese clastreana de igualdade. Ao contrário do etnólogo francês, essas descrições parecem afirmar que as atribuições eyiguayegui pareciam sim indicar distinções entre as pessoas, ainda que essas distinções não desembocassem na relação entre exploradores e explorados. Já em oposição à interpretação das fontes, seus próprios dados mostram que, mesmo operando oposições, os estatutos eyiguayegui não estão firmados sobre uma base de poder coercitivo.

"Dois axiomas, com efeito, parecem guiar a marcha da civilização ocidental", segundo P. Clastres (2003:211): “o primeiro estabelece que a verdadeira sociedade se desenvolve sob a sombra protetora do Estado; o segundo enuncia um imperativo categórico: é necessário trabalhar". Foi por meio do prisma desses dois axiomas que os Eyiguayegui foram lidos. Em primeiro lugar porque, como já discutido, o "trabalho" era (e ainda é) visto como sinal de civilização e do progresso das "bárbaras" populações em direção ao Estado e à humanidade plena. Em segundo porque o "trabalho" realizado pelos nibotagi e niyolola foi, na maior parte das vezes, entendido como evidência de que eles eram subjugados pelos niniotagi. O "trabalho" ao qual os documentos históricos se referem a todo o momento, nesse sentido, está intimamente ligado ao poder. Além de ser considerado "menor" e de estar localizado no âmbito doméstico ele seria também, de acordo com essa hipótese, realizado por uns para outros. Com todos esses fatores, a inferioridade dos nibotagi e niyolola torna-se inconteste e o quase surgimento do Estado - a gradual concentração de poder nas mãos dos capitães - parece mais do que óbvio. Porém, como já notado, os dados trazidos pelos documentos não sustentam a afirmação implícita de que haveria entre niniotagi, nibotagi e niyolola relações de hierarquia expressas na exploração do "trabalho" de uns pelos outros; na verdade contradizem essa hipótese, ao mencionarem a "falta" de autoridade dos supostos senhores e relações bastante complexas entre eles e seus "servidores".

Outro problema haveria em aplicar um modelo europeu de exploração do trabalho ao caso: com base nas fontes, é possível afirmar que as tarefas realizadas nas tolderias eyiguayegui não resultavam na acumulação. Sua "nação" chegou a ser descrita 
como "misérrima" 75 e suas expedições guerreiras foram muitas vezes entendidas como uma tentativa de sair da "pobreza" em que viveriam, portanto, também os "senhores". Tais testemunhos podem ser iluminados pelo "prisma da abundância" proposto por Sahlins (1972), evidenciando que não era o enriquecimento de sua "nação", e nem dos nobres, o resultado das tarefas cumpridas por "servos" e "escravos".

O "sofrimento" atrelado à noção de trabalho desde, no mínimo, a Idade Média não fazia sentido em terras chaquenhas, e este é outro ponto que a análise de Sahlins citada acima ilumina. Mas é interessante notar que a noção de trabalho como pena sobreviveu a séculos e se encontra ainda em escritos contemporâneos, como os de P. Clastres quando este afirma que os Tupi-Guarani dedicavam a maior parte de seu tempo "a ocupações sentidas não como penosas [como seria a preparação da terra para a agricultura], mas como prazerosas - caça, pesca, festas e bebedeiras - e à satisfação de sua paixão pela guerra" (Clastres 1974:65, tradução e grifos meus). Podemos nos perguntar se os "sentimentos" em questão (labuta e prazer) teriam sido assim expressos pelos próprios índios, coincidindo com classificações europeias, ou se estas apenas persistem, desde o século XVI, sem que se saiba ao certo como os índios qualificam diferencialmente as tarefas que desempenham.

Seria produtivo, portanto, pensar em "trabalho" quando falamos das sociedades chaquenhas? A noção, que traz em si a oposição obrigação/ lazer, parece não descrever muito bem a divisão de tarefas eyiguayegui. E há ainda outro pressuposto nessa noção. Vejamos as características do que as fontes de Sahlins ${ }^{76}$ consideram "trabalho": a caça, a coleta de vegetais, o preparo de alimentos e o conserto de armas. Todas elas ligadas a atividades que garantem a alimentação, ou seja, a subsistência. Mesmo em P. Clastres (2003:215) há uma diferenciação entre as atividades que visam "a satisfação global das necessidades energéticas" e aquelas ligadas à "ociosidade, o jogo, a guerra ou a festa". Em relação aos Eyiguayegui, afirma-se do mesmo modo que homens e mulheres cativos executavam a maior parte das tarefas domésticas e de subsistência"77 das tolderias, permitindo que os "senhores" dedicassem sua vida a outras atividades, como a guerra e o lazer.

Mas, se concordamos que essas populações não vivem em uma economia de subsistência e sim de abundância, creio podermos afirmar também que a produção de

\footnotetext{
75 Almeida Serra (1850:210).

${ }^{76}$ McCarthy e McArthur (1960). Os autores trazem os dados que baseiam a teoria da "economia da abundância" de Sahlins, mostrando o tempo de ocupação com cada atividade em grupos de "caçadores e coletores".

77 Santos Granero (2009:141, tradução minha).
} 
alimentos (no sentido de criação de energia calórica) não deve ser fundamental para a categorização de suas tarefas. Pois se entendêssemos como ponto central da distribuição de tarefas eyiguayegui a divisão de atividades que visam ou não a subsistência ela realmente não faria sentido: enquanto os niyolola e nibotagi plantam e cozinham, os niniotagi caçam e pescam. Ou seja, além de nenhum grupo explorar o outro, ambos os "polos" dessa relação contribuiriam para a alimentação, não parecendo ser a subsistência o fator de diferenciação entre as categorias. Além disso, a interpretação pela via da subsistência simplesmente desconsidera o destino dos produtos produzidos pelo assim chamado trabalho, que eram justamente as festas e bebedeiras a que todos, em conjunto, se dedicavam (Perrone-Moisés 2015).

No mais, é importante notar que, ainda que as fontes generalizem e afirmem que o "trabalho" estava nas mãos de nibotagi e niyolola enquanto os niniotagi não faziam nada além de festejar e guerrear, não é raro que "senhores" e "escravos" sejam descritos realizando as mesmas atividades: cozinhando, cuidando dos cavalos, fazendo arcos e flechas, indo para a guerra... Segundo Pechincha (1994: 52), na época das crônicas coloniais, "boa parte das ocupações dentro da vida da tolderia era compartilhada entre senhores e cativos". De fato, a leitura das fontes e das etnografias atuais faz perceber que apenas algumas dessas atribuições pareciam definir certos tipos de pessoas: como vimos, os niniotagi apareciam como grandes anfitriões, negociantes e guerreiros, enquanto as outras categorias eram ligadas à agricultura e ocupações "domésticas”. As outras atividades, por sua vez, eram divididas por todos.

Os últimos pontos levantados - a não-exploração do trabalho, a divisão das atividades de subsistência e mesmo de serviços considerados mais corriqueiros (todos esses por sua vez inseridos na noção de "economia da abundância") - estão entre os motivos que levaram diversos outros antropólogos a desconsiderarem o "trabalho" como fundamento dessa relação e a deslocar as distinções por atribuições para outro âmbito, mais "simbólico", por assim dizer. Depois de afirmar que as tarefas cotidianas de "senhores" e "cativos" são na maior parte das vezes parecidas, Pechincha, por exemplo, conclui que a única "distinção [entre senhores e cativos] esta[ria] em que ao cativo cabia servir ao seu senhor" (Pechincha 1994:52, grifos da autora). Ou seja, todos podiam fazer tudo, mas apenas alguns faziam certas coisas para os outros. A distinção estaria mais em como os nibotagi e niyolola exerceriam suas atribuições do que no tipo de tarefas por eles realizadas. A servidão está, portanto no centro desse tipo de leitura das relações entre atribuições e a próxima seção se destina à apresentação de como essa noção se desenhou na literatura especializada. 


\title{
2.3 Sobre a servidão: como as tarefas eram feitas
}

De acordo com a descrição de Azara citada na Abertura, os presentes dados pelos europeus aos capitães eram recebidos pelos cativos: segundo ele, lhe "aconteceu de presentear um mbayá que não quis receber o regalo, ordenando a um de seus escravos recebê-lo”. De maneira parecida, os nibotagi são descritos em outras páginas trazendo água para que seus "senhores" pudessem lavar as mãos após as refeições ${ }^{78}$ e efetuando o trabalho de mensageiros, levando convites e comunicados de toldo em toldo. Os documentos descrevem esses pequenos atos dos "escravos" como momentos em que a "nobreza" dos niniotagi era reafirmada. Boggiani, por exemplo, se espanta com a "estranha submissão" de um menino chamacoco quando, tendo-lhe dado

\begin{abstract}
uma cana de açúcar para que a chupasse, êste ao invés de a reservar para si deu-a, com a maior boa vontade e desinterêsse, ao seu pequeno senhor, que estava presente. Êste, como coisa que lhe era devida, a pegou e levou embora sem nem mesmo sonhar com dar uma parte ao pobre escravozinho que, porém, não se arriscou a fazer o menor ato de aborrecimento (Boggiani [1795]:135).
\end{abstract}

De acordo com a interpretação dos autores das fontes, haveria nesses atos uma prova da servidão dos cativos, muito próxima da europeia, em que a divisão da sociedade entre dominantes e dominados levaria a atos servis também em outras esferas. As análises antropológicas e etnografias contemporâneas tendem a concordar com essas impressões apenas em partes, por vezes divergindo sobre o lugar e a consequência da servidão entre os Eyiguayegui.

Santos-Granero (2009), por exemplo, afirma que esses atos servis não se originam em uma desigualdade de condições materiais de capitães e cativos, como alegam as fontes. Segundo ele, o trabalho não é o centro da concepção de escravidão ameríndia (conceito defendido pelo autor), ao contrário do que acontece na noção ocidental. Prova disso é que grande parte da população em idade adulta (ou seja, na idade ideal para trabalhar) era morta nas expedições guerreiras, sendo os cativos em sua maior parte crianças. De acordo com o antropólogo ${ }^{79}$, aos (poucos) adultos e às crianças raptadas eram atribuídas não atividades produtoras de excedente (ou seja, "trabalho"), mas "tarefas domésticas ou simbólicas, como servir seus mestres em ocasiões formais", ou como aquelas descritas pelos documentos históricos. Essas tarefas "simbólicas" realizadas pelos cativos transformá-los-iam em "assistentes pessoais" responsáveis, além dos serviços domésticos, por pequenas - porém significativas -

\footnotetext{
${ }^{78}$ Sánchez-Labrador ([1770-1776], v. I: 274).

${ }^{79}$ Santos-Granero 2009:199, tradução minha.
} 
tarefas. De acordo com as fontes consultadas pelo antropólogo (as mesmas consideradas aqui), esses

assistentes pessoais tomavam conta das menores necessidades de seus senhores e senhoras, chegando ao ponto de, quando estes ficavam doentes, ficarem ao lado de sua cama para afugentar as moscas (Santos-Granero 2009:142, tradução minha).

Para o antropólogo, a importância desses serviços pessoais não era a contribuição para a economia eyiguayegui, como afirmado acima, mas a exaltação do prestígio de seus "donos" e de "sua posição política em relação a seus seguidores, vizinhos e rivais" ${ }^{30}$. De acordo com Santos-Granero, portanto, mesmo que não houvesse uma relação de exploração, haveria ainda uma relação baseada no poder: a ocupação dos cativos com atividades "pequenas", em sua tese, parece ter o mesmo efeito de atividades aqui consideradas "trabalho", ou seja, elas também acabariam por aumentar o poder da aristocracia eyiguayegui ${ }^{81}$.

Algumas etnografias contemporâneas tendem a concordar apenas parcialmente com as conclusões de Santos-Granero. Se, por um lado, elas também descrevem os cativos "servindo" aos capitães em determinados momentos, por outro elas não afirmam que esses atos servis tenham grandes consequências políticas. Na maior parte das vezes, afirma-se que não há efetivamente grandes diferenças entre capitães e cativos e que, se elas existiram, ficaram no passado descrito pelas fontes. Mônica Pechincha (1994:75), por exemplo, afirma nunca ter observado "na rotina da casa kadiwéu" em que ela se hospedou "indicadores de servidão direta a quem quer que fossem seus senhores” e completa: “[e]mbora um cativo sempre atenda ao pedido do seu senhor pedidos que não são cotidianos ou constantes $-[\ldots]$, o sistema do cativeiro funciona hoje em dia basicamente para efeitos rituais". Ou seja, segundo a antropóloga, os cativos podem até fazer algumas tarefas requisitadas pelos capitães, mas o fazem apenas no âmbito "ritual", delimitado pela autora nos momentos em que os cativos "saem para convidar para as festas nas casas de seus senhores" 82 e em que eles "dançam

\footnotetext{
${ }^{80}$ Santos-Granero (2009:127).

81 "I argue that, in native tropical America, captive slaves and other subordinate peoples rarely replaced their masters in the sphere of production. They were required, however, to perform the heaviest, dirtiest, and lowest-ranking activities, thus making an important contribution to the economy of slaveholding households. In addition, they were required to provide a large number of small, noneconomic personal services" (Santos-Granero 2009:127).

82 Considerar a função de mensageiro como "menor" é, claramente, uma interpretação apressada das fontes e dos antropólogos, visto que a tarefa, em outros contextos etnográficos americanos (como entre os Kalapalo do Alto Xingu), é considerada extremamente prestigiosa e digna dos nobres (Guerreiro Jr. 2012:308)
} 
para os seus jovens senhores, quando estes participam pela primeira vez da festa do 'bate-pau’”.

Se antes a distinção capitães-cativos era considerada operante apenas na esfera "cotidiana" e das atividades "de subsistência" (ao ponto de Susnik (1972: 67) afirmar, fundamentada na análise das fontes, que aos "nibotagi, hombres y mujeres, correspondía todo el trabajo, identificádose - según el concepto mbayá - con cualquier actividad que carecía de una concomitante sociocerimonial”), uma parte da literatura atual tende a reverter esse quadro e afirmar que essa distinção não opera no dia a dia das aldeias kadiwéu, mas apenas no domínio do "ritual" ou do "simbólico". Por essa razão observa-se a tendência, em algumas produções, de deixar a "hierarquia" kadiwéu de lado - ela parece estar apenas nos sistemas de pensamento, mas não nas relações observáveis. De acordo com essa hipótese, se não parece haver servidão de fato, com consequências "materiais" para a economia e política eyiguayegui/kadiwéu, no lugar dela haveria uma servidão ritual. Obviamente, existem exceções. Jaime Siqueira Jr. (1993: 272), por exemplo, afirma que as relações entre capitães e cativos "permeiam e ‘costuram’ toda a estrutura social kadiwéu, manifestando-se especialmente” não apenas na esfera ritual, mas também política do grupo.

Parecem existir dois motivos para o atual "apagamento" das diferenciações kadiwéu (observada também nas análises sobre a "simbiose" eyiguayegui-guaná demonstradas no capítulo anterior). Primeiro: uma "divisão" social que não aquela entre dominantes e dominados é raramente considerada e a solução encontrada é a de deslocar essa diferenciação (constantemente afirmada pelos Kadiwéu) para a esfera simbólica. Segundo: opera-se uma distinção entre "ritual" e "político" que acaba por fabricar ruídos e complicar a apreensão daquilo que a análise recorta com tal distinção (ver Perrone-Moisés 2015). Como vimos, Pechincha considera funções rituais os papéis desempenhados por cativos nas festas oferecidas pelos capitães, o que a faz desvalorizar a importância política da oposição cativos-capitães.

Segundo Beatriz Perrone-Moisés (2015:14), análises como essa - numerosas na etnologia sul-americana - acabam por recortar “indevidamente as festas dos índios", entendidas pela autora como "grandes eventos [em] que se fazem e refazem a vida social”. As festas dos índios americanos não cabem em nenhuma de nossas categorias: nelas estão presentes aquilo que chamamos "política", dança, música, comida e aquilo que denominamos muitas vezes "religião" - a relação com as gentes de outros planos, conhecidos como "espíritos" (Perrone-Moisés 2015: 14). Considerando esse limite da categoria "ritual”, Perrone-Moisés propõe um ajuste de vocabulário: ver como festa 
aquilo que geralmente se vê como ritual. Quando prestamos atenção naquilo que os índios chamam de "festa" percebemos que elas são a chave para a compreensão das políticas ameríndias (Perrone-Moisés 2015: 15): no caso eyiguayegui, como podemos ver na descrição da festa de fabricação do capitão, as diferentes categorias de capitães (elegi e niniotagilionigı) são produzidas em festas e as danças com os escalpos trazidos da guerra (consideradas muitas vezes o ápice da guerra chaquenha, como veremos no próximo capítulo) originam grandes bebedeiras. As diferenciações eyiguayegui - base de sua política - são construídas e reativadas nas festas. Longe de serem acessórias à politica, como muitas vezes elas foram vistas, elas são, para os ameríndios, a política em si (Perrone-Moisés 2015:15).

Afirmar que as diferenciações eyiguayegui são apenas rituais, portanto, não nos aproxima do entendimento da natureza dessas relações. Os dados trazidos pelas fontes e etnografias nos dizem a todo o momento: ao mesmo tempo em que essa assimetria não se fundamenta em uma relação de trabalho tal como conhecemos, ela também não se baseia em uma distinção apenas "de ideologia". Ou seja, as pessoas não se distinguem por uma relação de exploração mas mesmo assim são constantemente distinguidas, reconhecidas (e fabricadas) como opostas. Como veremos adiante, mesmo as descrições sobre o jeito, o porte, o corpo de cativos e senhores são extremamente diferentes.

No mais, faz-se importante notar que esse tipo de interpretação das distinções por estatutos como algo simbólico ou ritual não é exclusiva do caso eyiguayegui. As relações supostamente hierárquicas do Alto Rio $\mathrm{Negro}^{83}$, por exemplo, foram muitas vezes entendidas como essencialmente rituais e essa categorização parece estar diretamente ligada à denominada "dialética entre hierarquia e igualitarismo" (Andrello 2004: 286) considerada característica da região pela literatura especializada. Essa dialética, presente em descrições como a de Irving Goldman (1963: 92), que chega a definir a organização social cubeo como estruturada por um "esqueleto aristocrático" preenchido por um "ethos igualitário”, também acabou por separar o nível "ritual” do “político". Segundo Pedroso (2013:50), a hierarquia cubeo está fundada, entre outros elementos, na relação dos diferentes sibs com seus ancestrais, cada um responsável por um conjunto de nomes. Essa distribuição de nomes, por sua vez, acabaria por ordenar os sibs em uma escala hierárquica relacionada à ordem de nascimento dos ancestrais. $\mathrm{O}$ argumento de Goldman (1963) é o de que esses nomes seriam importantes apenas em

\footnotetext{
83 O complexo multilinguístico do Alto Rio Negro é um dos exemplos mais citados de "hierarquia" ameríndia. De maneira geral, sua base é o ranqueamento regional medido pela ordem de aparição dos ancestrais de cada um dos grupos (Lolli 2010: 12), além de um ranqueamento "interno" aos sibs, compostos por partes de servidores, xamãs, guerreiros, cantores e chefes (Andrello 2004: 288).
} 
momentos rituais - ou seja, nas festas -, em que as histórias de cada sib são contadas publicamente. Segundo o autor, nos outros momentos da vida social cubeo essa hierarquia não seria tão importante, sendo mais comum encontrar traços de "igualdade" no seu cotidiano do que de uma centralização do poder em uma só figura política. De acordo com Pedroso (2013: 57, grifos do autor), a tese do autor americano é a de que os Cubeo realmente têm uma "ordem social hierárquica", mas "tal hierarquia 'apenas' confere prestígio, não confere poder, não implica desigualdades de ordem social ou material-econômica $[\ldots . . .]^{84}$.

Em seu estudo sobre os Tariano, também habitantes do rio Uaupés, afluente do rio Negro, Geraldo Andrello dissolve essa dicotomia. Segundo o autor, as histórias e os nomes relacionados aos ancestrais de cada sib acabam por dar acesso privilegiado a certas posições, como a de liderança. Ainda que essas histórias possam ser mobilizadas de maneira a "furar" o ranqueamento - o que efetivamente acontece -, portanto, "a hierarquia entre os sibs não pode ser considerada apenas como um construto ideal que expressa uma ordem mítica, pois em determinadas circunstâncias parece efetuar-se concretamente" (Andrello 2004: 289).

Ademais, a divisão simbólico/político pode, como afirma Perrone-Moisés, nos fazer pensar no ritual como acessório à política e, muita vezes, como um meio de afirmar um poder político que já está pressuposto. Para Santos-Granero, por exemplo, por mais que os "escravos" não contribuíssem economicamente para seus "senhores", os "serviços pessoais" (vistos algumas vezes como rituais) eram a eles atribuídos para que eles se lembrassem continuamente de "que eles eram estrangeiros e inferiores e que seus senhores podiam fazer com eles o que quisessem" (Santos-Granero 2009:128, tradução minha). Segundo o autor, é exatamente nessas pequenas tarefas servis que se observa a existência de uma relação de "escravidão" chaquenha e ameríndia. De maneira parecida, Pechincha (1994:64-5) afirma que

[a] assimetria entre os dois grupos bipolares da sociedade Mbayá se funda na relação de poder: os cativos são presas de guerra. Menos que interdependência, o cativo estaria ligado a seu senhor por sujeição. $\mathrm{O}$ cativo é aquele a quem cabe servir a um senhor, e isto é uma diferença fundamental.

Voltamos, desse modo, ao primeiro ponto levantado acima: parece ser impossível pensar em sociedades divididas mas não atravessadas pelo poder coercitivo.

A questão que se impõe aqui é se esses "serviços pessoais" devem mesmo ser vistos como evidência do suposto poder dos niniotagi sobre os nibotagi. Essa suposição,

\footnotetext{
${ }^{84}$ Voltaremos adiante para a questão do prestígio.
} 
como vimos, não é exclusiva dos antropólogos. Em uma seção de seu livro denominada "Presunción de los Mbayás”, Sánchez-Labrador ([1770-1776], v. I:273) conta:

Fuí como solía un día a visitarles. Entré en el toldo de un capitán anciano. Comía éste actualmente, y le servían sus criados: de éstos unos cuidaban el fuego; otros de cosas conducentes á que quedase bien servido el amo. Acabó éste de comer y también los criados. Notó en mí alguna atención en observarlos, y me dijo: Mi padre, ¿qué te parece de nuestro modo? Somos como los Españoles: los señores nos dejamos servir de nuestros criados. Aquél es mi lugar y el de mi mujer y de José (era un hijo suyo ya cristiano), aquél el de los criados que como ves están separados. ¿No lo hacen así los Españoles?

O diálogo descrito pelo missionário nos mostra um duplo esforço de tradução. De um lado, o do jesuíta, que traça um paralelo evidente entre a servidão europeia e a relação entre capitães e cativos nas tolderias. Esse paralelo fundamenta-se em todos os pontos levantados acima e também nas evidências consideradas "menores", esses pequenos serviços efetuados pelos nibotagi - no caso, a separação espacial entre capitães e cativos e o fato de os últimos servirem a refeição aos primeiros -, também considerados prova de sua total rendição. Do outro lado está o empenho de tradução do niniotagi interlocutor de Sánchez-Labrador: se essa comparação foi realmente efetuada pelo eyiguayegui, ela parece ser um esforço de aproximação das relações indígenas às europeias.

A grande questão que emerge dessa comparação é o que exatamente o niniotagi estava comparando. A aposta de Sánchez-Labrador e de grande parte da literatura chaquenha é que o ponto de contato entre as "relações de servidão" eyiguayegui e europeias seria o poder que as basearia. Mas a fala do capitão também pode apontar para outra direção, pouco explorada pelos estudos até agora. Por um lado, ele parecia comparar a distinção entre duas categorias de pessoas diferentes, similar (apenas em alguns aspectos) àquela entre os senhores e servos feudais, e que se mostrava também na separação espacial entre niniotagis e nibotagis. De outro lado, o capitão parecia equiparar as maneiras de servir de servos europeus e nibotagi/niyolola, maneiras essas que podem não ter nada a ver com concepções de poder ocidental. Pois ao mesmo tempo em que estava sendo servido por seu "escravo", o "senhor" comia a mesma comida que ele, ainda que em lugares diferentes e, pelo que tudo indica, morava na mesma casa que ele, costumes inaceitáveis na noção europeia de escravidão.

Aliás, não são raras as alegações de que aquela se tratava de uma "esclavitud muy dulce", porque os nibotagi e niyolola se submetiam a ela voluntariamente e a deixavam quando lhes apetecia. Afirma Azara (1809:56): “además, sus dueños les davan bien pocas órdenes, no empleavan jamás tono imperioso ni obligatorio”. Do mesmo 
modo, Taunay (1840:83) escreve que os "escravos" eram tratados com "brandura" e que jamais os obrigavam a trabalhar. E os exemplos se multiplicam. Jaime Siqueira Jr. (1993:126) vai na mesma direção quando afirma que, atualmente, "[t]odos os descendentes de cativos, em geral Chamacoco, possuem estreitos vínculos com os descendentes de seus senhores, que não se expressam mais na prestação de serviços diários embora devam ser solícitos quando requisitados para a realização de algum favor". Mesmo que o antropólogo tenha como pressuposto o fato de que antigamente os Eyiguayegui eram estratificados e hoje em dia não são mais, as fontes parecem, de modo muito parecido com o de Siqueira Jr., também demonstrar que os serviços feitos pelos cativos pareciam mesmo com "favores": assim como hoje, eles não eram obrigados a nada, fazendo-os porque queriam.

De maneira similar, lavrar a terra (atividade atribuída aos niyolola) também pode ser vista como uma atividade não imposta: como vimos, os niyolola iam às terras eyiguayegui voluntariamente cultivar suas roças. Como afirmado no capítulo anterior, essa voluntariedade dos niyolola - agora estendida também aos nibotagi - instigava os autores das fontes, que não entendiam a vontade de alguns de servir a outros. A questão das fontes se aproxima, de certo modo, daquela levantada por Étienne de La Boétie (1987) em seu Discurso sobre a servidão voluntária: o que levaria uma "nação" a não "levantar-se nem lamentar-se" da situação de servidão, suportando esse "infortúnio com resignação" 85 ? Tendo a liberdade de recusar tal relação, por que tais grupos continuavam sob o jugo de outros? De fato, os niniotagi não pareciam obrigar os niyolola nem os nibotagi a serviço nenhum. Então por que eles continuavam se ocupando daqueles serviços "menores"?

Aqui, a chave da questão parece estar não na voluntariedade da servidão, mas na servidão em si, que não existe no caso eyiguayegui. O ato de realizar certos "serviços" para outrem, em terras chaquenhas, não está fundamentado em uma relação de coerção como está a servidão europeia. E esse não é o único caso de "servidores voluntários" nas Américas: vimos no capítulo anterior o caso dos Paumari, e também entre os Kalapalo, povos de língua karib do Alto Xingu, afazeres como esses são comuns. A palavra kalapalo geralmente traduzida como "empregado" - ngengoku -, por exemplo, se refere a "[q]ualquer pessoa que seja mandada para fazer algo, como buscar um objeto, dar um recado, fazer uma viagem, fazer um trabalho" (Guerreiro Jr. 2012:313). Se alguém faz uma roça para um chefe, este alguém é ngengoku do capitão. Mas, ao

\footnotetext{
${ }^{85}$ La Boétie (1987 : 74).
} 
contrário do que esperaríamos, essa palavra não traz nenhuma marca de inferioridade, sendo utilizada frequentemente para falar dos funcionários de órgãos do governo, "todos entendidos como, em última medida, ngengoku de quem ocupa a presidência da república”. Os dados de Guerreiro Jr. nos fazem ver que as relações de "trabalho" entre os Kalapalo não necessariamente trazem consigo uma divisão hierárquica, não definindo uma posição fixa nem para aquele que faz o trabalho, nem para aquele que o demanda. O interessante desse vocábulo, segundo o autor, é exatamente isso: ele é usado apenas para se referir a contextos específicos e à relação de uma pessoa com a outra, ou seja, não se formam "classes sociais" de ngengoku e de "patrões". Sugiro que os dados eyiguayegui sejam lidos nessa chave: não podemos negar que alguns fazem determinados serviços para outros, mas podemos duvidar do sistema hierárquico que se supõe por trás desses atos.

Entender as atribuições como a "essência" dos nibotagi, niyolola e nibotagi, dos homens e das mulheres, como faziam os autores das fontes, pode nos levar a conclusões apressadas, pois ao mesmo tempo em que fica claro que as tarefas realizadas pelas pessoas indicam suas diferenças em relação às outras, é possível também afirmar que essas diferenças podem ser desfeitas ou refeitas. Só poderíamos considerar a atividade como a "essência" de homens e mulheres, chefes e cativos eyiguayegui se a considerássemos em sua instabilidade crônica: a literatura americanista nos mostra cada vez mais ser possível que relações entre "servidores" e "patrões" se transformem em outras quando muda o contexto. Tomando mais uma vez emprestada a análise de Guerreiro Jr.: num primeiro momento, certas pessoas podem ser ngengoku de outras; num segundo, podem não ser. Em minha leitura, vem exatamente daí a confusão de várias fontes e até de alguns antropólogos: em alguns momentos é possível enxergar relações de "serviço" (quando um cativo lava a roupa para uma "senhora", por exemplo) e em outros não (e as descrições do "amor" e do "carinho" entre nobres e cativos são evidência disso).

\subsection{Nobreza eyiguayegui}

Em suma, pensar as "relações de trabalho" é de extrema importância. Nas tolderias e aldeias eyiguayegui e kadiwéu, como vimos, parece haver um "código de honra" que estabelece uma divisão de tarefas: os niyolola cultivam a terra enquanto os oquilidi fazem seus frutos circularem. As roças, como afirmado, são hoje em dia muito 
mais frequentes nas aldeias mais habitadas pelos Terena, “[...] considerados como grandes plantadores, porque além $\mathrm{d}[\mathrm{e}$ cultivarem um $]$ a quantidade de roças, dificilmente perdem uma colheita" ${ }^{6}$. Em relação aos Terena, os Kadiwéu plantam "comparativamente menos, com roças familiares de no máximo dois alqueires", preferindo se ocupar das "criações próprias de gado e cavalo" 87 - ocupações consideradas nobres pelas fontes históricas.

Essa distribuição de tarefas, por sua vez, aparece em diversas narrativas sobre o surgimento das diferentes gentes. Segundo Basília, interlocutora de Jaime Siqueira Jr.,

$\lceil 1\rceil$ ogo que Deus fez o mundo, lembrou de todas as tribos, todos os índios e também os Kadiwéu, e deu a terra que é essa que estamos morando e todos conhecem. Então é por isso que ninguém pode tomar a terra do índio. Porque logo que existiu o mundo já existia os Kadiwéu e cada tribo tinha o seu jeito de viver e Kadiwéu era guerreiro e vivia da caça e pesca. Quando Aneotedrodi (Deus) terminou de fazer cada tribo, ensinava o que eles podiam fazer: deu enxada para Terena, foice para os brancos e para o Kadiwéu deu a terra, porque Kadiwéu não pode carpir, não sabe carpir (Siqueira Jr. 1993: 123, grifos meus).

O “jeito de viver" dos Terena parece ser considerado por Basília logicamente diferente, mas não necessariamente inferior. O seguinte testemunho de um jovem senhor kadiwéu, que conta de quando Gonoegodi (personagem responsável pela criação do mundo, dos Kadiwéu e de outros povos) tira os povos de um buraco, criando-os, vai nessa direção:

E lá estavam todas as nações, os Kadiwéu, bolivianos, paraguaios, portugueses, alemães, japoneses. Naquele buraco tinha todas as nações, que agora já estamos separados. Deus tirou todas as nações do buraco, até os Kadiwéu. Deus deu para os ecalaile (os brancos) o que até hoje eles são, umas pessoas educadas, fazendo as coisas que a gente chega a admirar. Eles são diferentes dos índios, eles fazem muitas coisas. Depois dos ecalaile, ele tirou a nação dos Terêna. Os Terêna até hoje deus deu para eles serem trabalhadores, lavradores. Para eles não tem nada de preguiça, sempre trabalhando. É porque deus lhes deu semente do algodão para plantarem e para as mulheres tecerem alguma coisa. Semente de abóbora, plantação de mandioca, banana, o que eles plantam agora. Deus disse para eles: 'vou dar para vocês a semente do algodão, que isto aqui vai ser uma veste para você depois que você colher'. O nome daquela veste é niwiGate. Até hoje as mulheres Terêna sabem tecer o algodão. Isto foi um presente de deus, porque os Terêna esperaram aquilo que deus queria dar para eles (Pechincha 1994: 113).

Considerar a aptidão para a agricultura um "presente de deus" indica, certamente, uma influência do cristianismo nas maneiras de pensar kadiwéu - suas aldeias estão em contato com as igrejas católica e evangélica há séculos -, mas

${ }^{86}$ Siqueira Jr. 1993: 156.
${ }^{87}$ Siqueira Jr. 1993: 157. 
considero ser possível também pensar essa afirmação como um reconhecimento da importância inegável dos trabalhos da terra e mesmo do privilégio daqueles que com eles se ocupam. Em suma, as novas etnografias mostram que as diferentes atribuições parecem ser pensadas pelos Kadiwéu em chaves diferentes daquelas da submissão, tanto no caso dos niyolola quanto dos nibotagi.

Chamados pelos Kadiwéu de "criados" ou "cativos" (Lecznieski 2005: 113), os descendentes de nibotagi vivem hoje em dia junto de seus capitães, como afirmado. Aliás, segundo Lecznieski, vem exatamente daí a escolha, pelos Kadiwéu, dos termos em português para denominá-los: em ambos os casos, eles expressam a ideia de criação e de cativação gradual que serão discutidas no próximo capítulo. Não necessariamente incluídos em uma ideia de sujeição, portanto, os termos utilizados na designação dos nibotagi nos permitem enxergar suas tarefas (principalmente aquelas por ocasião das festas) de outra maneira ${ }^{88}$. Por mais que tenham sido correntemente descritos como "apenas" servidores nas borracheiras - aqueles que levam os convites das festas aos outros toldos, servem a bebida a seus "senhores" 89 e os levam até suas casas depois de embriagados -, por exemplo, os criados poderiam ser entendidos, ao contrário, como "mestres" dessas bebedeiras, aqueles que conduzem seu andamento e mesmo as aventuras vividas pelos bebedores ${ }^{90}$. De qualquer modo, os cativos não servem a bebida em todas as borracheiras: na festa da moça descrita pelas etnografias atuais e discutida adiante, por exemplo, são eles os que sentam no couro e bebem, sendo servidos por outras pessoas. Mesmo a repartição das atribuições, portanto, não é fixa, como desenvolveremos a seguir.

Entre os Kalapalo, assim como entre os Eyiguayegui, a "divisão do trabalho" também permeia o sistema político e se fundamenta em diferenciações contextuais. Em sua língua há expressões que diferenciam os tipos de tarefas entre si. Anetü kasu, por exemplo, é traduzido por "trabalho de chefe", onde a raíz ka se refere ao trabalho e anetü aos nobres kalapalo. Segundo Guerreiro Jr. (2012:145), o trabalho é dividido pelos Kalapalo em duas raízes: a raíz ha refere-se a "um fazer concreto (produzir, construir, manufaturar)", e é geralmente utilizada na "produção de objetos materiais como casas, ferramentas, utensílios, ferramentas musicais, etc.”; enquanto üi se refere a

${ }_{88}$ Considerar os termos utilizados pelos Kadiwéu como dados de análise, por sua vez, tem a intenção de "levar a sério o português dos índios", tantas vezes ignorado nas produções antropológicas (PerroneMoisés 2015: 18).

89 Santos-Granero (2009: 164, tradução minha) afirma que os cativos "atendiam as necessidade de seus senhores durante as bebedeiras". Boggiani ([1895]), que descreve muitas festas, sempre descreve os cativos servindo seus "senhores" nas borracheiras.

90 A hipótese da "maestria” nas bebedeiras é levantada por Vitar (2016: 69) em relação às velhas guaicurú e será melhor discutida no próximo capítulo, assim como as "aventuras" dos bebedores citadas adiante. 
um fazer mais "abstrato" relacionado ao "preparo dos alimentos, à realização de uma pesquisa, do fazer fogo”... Este último estaria intimamente ligado ao fazer dos anetü, constituídos por meio de um longo processo de "aprendizado de conhecimentos específicos", enquanto ha estaria mais próxima de uma tarefa considerada não-nobre. Como salienta o autor, essa não é uma oposição rígida (assim como aquelas entre os Eyiguayegui), podendo ser reinterpretada de acordo com as relações em jogo.

No mais, é importante frisar que as festas eyiguayegui - e, portanto, sua aristocracia - são impensáveis sem os cativos. Como afirma Lecznieski (2005: 162-3), sem cativos que "possam levar os convites para as festas de seus senhores e senhoras", não haveria "festas e as famílias nobres estariam descumprindo a etiqueta". A divisão de tarefas, nesse sentido, é de extrema importância para a construção cotidiana da nobreza eyiguayegui, que não é um esforço apenas dos nobres.

O que importa aqui é salientar três fatores. Em primeiro lugar, um ponto já discutido durante o capítulo: o fato de que uma atribuição considerada nobre só existe em oposição a outra entendida como não-nobre. Essas oposições, em terras ameríndias, não estão atreladas a determinados grupos de pessoas de modo definitivo e constante, mas acabaram por ser interpretadas de maneiras mais ou menos estanques ao longo do tempo.

Em segundo lugar, há evidências de que tanto nobres quanto não-nobres contribuem para a fabricação da nobreza. No caso eyiguayegui, tanto a relação entre niyolola e oquilidi quanto aquela entre niniotagi e nibotagi colaboram, por meio das distinções nas atribuições, para a construção da sua aristocracia. Vimos que os nibotagi participam da festa de criação do cacique em vários momentos: um cativo recémnascido é feito amigo do capitãozinho; um nibotagi dá ao capitão recém-nascido um cavalo em troca do título de niniotalionigi concedido ao pequeno cativo; um velho nibotagi canta as futuras proezas do capitãozinho e é recompensado com uma manta (tecida por uma capitã guaná).... Como afirmado no início desse capítulo, no centro da festa estão o cacique e seu filho recém-nascido mas, além deles, estão também os cativos, parte imprescindível da nobreza. E eles não participam como pessoas “inferiores”, como poderíamos pensar: o fato de eles ganharem e darem presentes durante o octavário acaba por nos mostrar outras imagens das relações entre niniotagi e nibotagi, muito menos (e talvez nada) opressoras. Aí está mais um palpite acertado (mas nem tanto) das fontes: realmente, as tarefas dos nibotagi parecem contribuir para a nobreza de alguns, embora essa contribuição não acarrete na superioridade de uns e a inferioridade de outros. 
O terceiro ponto a ser salientado é que, assim como o caso eyiguayegui, o exemplo kalapalo brevemente apresentado também mostra como as tarefas podem ser entendidas fora da chave do poder em diversos povos ameríndios: como vimos, chefes e não-chefes podem ter atribuições diferentes, mas isso não os torna distintos em uma escala hierárquica, desiguais no sentido que damos ao termo quando combatemos “desigualdades" entre nós. Daí surge o aparente paradoxo que ronda a literatura sobre as populações indígenas supostamente hierárquicas: se não existe um poder que divide nobres de não-nobres, por que alguns "trabalham" em prol da nobreza de outros?

O exemplo dos Kalapalo trazido por Guerreiro Jr. (2012:145) pode iluminar, mais uma vez, essa questão. A nobreza entre aqueles índios, segundo o etnólogo, se fundamenta principalmente no conhecimento, na generosidade, nas relações construídas pelos nobres, entre outras coisas, e o "trabalho de chefe" parece falar mais sobre os deveres que os chefes têm com sua comunidade do que dos privilégios que teriam em relação a ela. Voltamos, então, para aquele ponto brevemente discutido no início do capítulo, o do "encargo" dos chefes ameríndios e dos elegi eyiguayegui.

Em sua análise das fontes históricas chaquenhas, Lévi-Strauss (1996: 184) escreve:

Para os nobres, e até certo ponto para os guerreiros, o problema essencial era o do prestígio. As descrições antigas mostram-nos preocupados em manter as aparências, não perder a dignidade e, sobretudo, não contrair um casamento com gente inferior.

Entender a nobreza como um "problema" pode ser, à primeira vista, uma decisão disparatada. Mas quando analisamos as descrições sobre os niniotagi percebemos que eles estão sempre preocupados em saber com quem casar, em como se portar, em distribuir uma grande quantidade de mantas guaná ou outros produtos conseguidos nas visitas a outros povoados, em oferecer as melhores e maiores festas... A preguiça a eles reputada parece cada vez mais deslocada, ainda mais quando consideramos as frequentes expedições de caça e de guerra - assunto para o próximo capítulo -, que também estavam sob sua responsabilidade. A literatura sobre os Eyiguayegui e mesmo as etnografias atuais sobre os Kadiwéu, porém, não trazem muitas reflexões sobre essa sobrecarga dos chefes e dos nobres, talvez por se deixarem levar pelo pressuposto de que a nobreza é sempre um estado melhor do que aquele dos não-nobres.

Ainda assim, as evidências trazidas pelas fontes parecem indicar que a nobreza eyiguayegui é constituída por um esforço recorrente de interação com o que é estrangeiro: espera-se dos nobres que eles se casem com estrangeiros, tragam cativos 
de fora, façam expedições de guerra com povos outros.... Todos os seus indicativos de aristocracia têm origem no exterior das tolderias. E aí chegamos à questão do prestígio, trazida tanto por Irving Goldman (1963) em relação aos Cubeo do Alto Rio Negro quanto por Lévi-Strauss sobre os próprios Kadiwéu: aquele prestígio que Goldman considera "apenas" ritual e que Lévi-Strauss entende como um verdadeiro "problema” para os nobres é o que confere a nobres e chefes uma posição política de destaque. E esse prestígio, ao que tudo indica, vem da "relação (ou interação) com a alteridade perigosa, com um Fora”, assim como em grande parte das Américas. Essa relação com o Fora, por sua vez, parece fazer dos nobres e chefes pessoas diferentes, ou diferenciadas na medida em que interagem com o outro; pois ao mesmo tempo em que o Fora é fonte de “uma espécie de agência, potência ou 'poder' cósmico” 91 , ela é fonte também do desconhecido e, portanto, do perigo $^{92}$. Estar disposto a se engajar nessa busca pelo estrangeiro é o que faz a nobreza ameríndia e eyiguayegui. Aliás, as narrativas kadiwéu mostram que o roubo de frutos, terras, objetos e pessoas estrangeiras é visto por eles próprios como sua "vocação" 93 , como mostra a seguinte história contada a Castelnau $([1850])$ :

Quando criou o mundo, o grande espírito deu a cada povo uma certa particularidade, cabendo aos brancos o comércio e a outros o instinto da agricultura. Os Guaicurus, sentindo-se esquecidos, procuraram então o grande espírito, para levar-lhes as suas queixas; percorreram assim as vastas solidões do Grão-Chaco, interpelando todos os animais e plantas que encontraram pelo caminho. Encontraram, finalmente, o Caracará, que dirigindo-se a um dele disse: Tu te queixas, e entretanto recebeste o melhor quinhão; pois uma vez que nada te coube na partilha, tens o direito de tomar tudo quanto tiverem os outros; foste esquecido, portanto poderás matar todos que encontrares. Não esperou o Guaicurú para seguir essas instruções, pegando logo de uma pedra e com ela matando o Caracará. Gabam-se os Guaicurús de ter depois daí seguido fielmente aquela lição (Ribeiro 1980a: 59, grifos meus).

E realmente a seguem até hoje em dia, segundo as etnografias. Um jovem senhor kadiwéu conta a Pechincha que, antigamente,

[o]s Kadiwéu viviam brigando. Acabaram com os outros índios que hoje não existem mais. Acabaram com os Xamakôko, com os Enima $\mathrm{G} a$. Foram empurrando os Terêna também. Brigavam com os Terêna porque às vezes queriam comida e os Terêna não davam (Pechincha 1994: 78, grifos meus).

\footnotetext{
${ }^{91}$ As duas citações são de Sztutman (2012: 75).

92 Como demonstrei no capítulo anterior, este "Fora" nunca está dado e não é o mesmo em todas as situações. O "outro" ao qual me refiro, nunca é demais lembrar, é definido contextualmente e em relação. ${ }_{93} \mathrm{O}$ roubo como vocação dos índios kadiwéu é longamente discutido por Lecznieski (2005: 49), que faz uma associação entre as "histórias dos corridos", o personagem mítico Gu-ê-krig e o "espectro do roubo", que permearia "seu imaginário e suas relações".
} 
Darcy Ribeiro (1980a: 65) também conta da vez em que foi chamado, em conjunto com os agentes do SPI, a intervir em um conflito entre famílias terena e kadiwéu. Segundo o antropólogo, "o conflito fora ocasionado pelas exigências de alguns capitães Kadiwéu que reclamavam parte das colheitas como tributo"94. O testemunho de Martinho acima citado também se refere à insistência dos capitães em receber os frutos da terra e da iminente ameaça de, sendo-lhes negados os pedidos, efetuarem roubos.

Esse direito ao roubo concedido aos Eyiguayegui era o que lhes permitia fazer "sem cessar a guerra a todas as outras nações, mata[ndo]todos os machos adultos e $\operatorname{adota}\left[\right.$ ndo] as crianças e as mulheres para aumentar seu número" ${ }^{95}$, prática tantas vezes descrita pelas fontes históricas. $\mathrm{O}$ investimento de todos na nobreza de alguns no caso eyiguayegui parece ser, portanto, uma maneira de fazer os "nobres" partirem em busca do exterior e trazê-lo para dentro das tolderias. E talvez aí esteja a diferença entre o guerreiro - aquele que parte para o exterior almejando a glória individual ${ }^{96}-\mathrm{e}$ os nobres e chefes - aqueles que buscam o Fora, atingindo certa singularização, mas que voltam para suas tolderias e a compartilham com seus aliados.

Apenas a busca pelo Fora, portanto, não é suficiente para fazer bons chefes: esse impulso para o exterior parece ser constituinte dos guerreiros eyiguayegui, mas não da chefia. Os elegi parecem necessitar trazer em si tanto esse ímpeto para o exterior quanto a capacidade de "cultivar continuamente os elos pessoais" (Perrone-Moisés 2012: 858), formando redes de apoio próximas a ele. Ou seja, precisam estender o prestígio que adquiriram fora de sua aldeia para seus aliados mais próximos. A circulação das mantas tecidas pelas capitãs guaná, que vem de fora e são o presente por excelência entre os Eyiguayegui, parece fazer parte desse sistema que é, ao mesmo tempo, centrífugo (porque parte de um ímpeto em direção ao exterior) e centrípeto (porque atenta também às relações pacíficas dentro das tolderias) (Viveiros de Castro 2004; Sztutman 2012).

Outra evidência desse movimento pendular ${ }^{97}$ entre o interno e o externo (sempre contextuais) é o casamento dos capitães exiguayegui com as capitãs guaná: os

\footnotetext{
94 É interessante notar que os constantes roubos que os "índios cavaleiros" efetuavam nas plantações guaná parecem ter sido um dos motivos para a qualificação, pelas fontes históricas, da relação niyololaoquilidi como baseada na coerção.

${ }^{95}$ Azara ([1809]).

${ }^{96}$ Clastres (2004).

97 A imagem do pêndulo trazida por Perrone-Moisés (2012: 868) remete à ideologia bipartite ameríndia como evidenciada por Lévi-Strauss (1993), que faz com que as oposições nunca sejam estáticas e estejam sempre em movimento. A política ameríndia seria, como tudo nos mundos ameríndios, uma coisa $e$ outra,
} 
niniotagi se casam com as unati e fazem conexões que se mostram tanto fora de sua tolderia - com a família de sua esposa, que os recebe em suas visitas sazonais - quanto dentro dela - com a sua esposa, que vem morar em seu toldo e acaba por trazer consigo aqueles "mutirões” de guaná que trabalham em suas roças. Aliás, esses mutirões parecem poder ser analisados de duas maneiras. Siqueira Jr. (1993: 156) conta que atualmente os Terena da aldeia Campina "realiza $[\mathrm{m}]$ mutirões denominados "troca de dia', onde especialmente em época de queimada e derrubada todos de um mesmo grupo familiar trabalham juntos um dia na roça de cada um”. O "trabalho" de alguns índios guaná nas roças do niniotagi descrito pelas fontes talvez possa ser entendido, portanto, em termos como esses, em que os familiares da capitã guaná e, por conseguinte, do capitão eyiguayegui, revezam-se no cultivo de roças que não são necessariamente suas. Mas é interessante pensar também na possibilidade de grande parte dos produtos da roça ser consumida nas festas oferecidas pelos capitães ou trocadas com os portugueses e outros povos por produtos que muito interessavam aos outros habitantes das tolderias. As roças cultivadas pelos Guaná (e atualmente pelos Terena e Kinikinau), portanto, não traziam benefícios apenas ao capitão: de alguma forma, eles eram redistribuídos, seja em festas, seja nas negociações dos "senhores", que trocavam os alimentos.

Sendo "mediadores por excelência” (Guerreiro Jr. 2012: 124), os chefes e nobres kalapalo também são aqueles que tecem relações para fora e as trazem para o cotidiano de suas aldeias. E não é só com chefes de outras aldeias que eles têm que se relacionar, mas também com os espíritos, os chamados apaapatai. Segundo Guerreiro Jr. (2012: $125)$,

[c]hefes que se tornam donos de muitos rituais para espíritos dispõem de muitas pessoas plantando roças para suas festas, o que lhes permite patrocinar esses eventos com mais facilidade. Além de ter seus parceiros rituais trabalhando para ele, com o patrocínio de festas um chefe consegue desempenhar o papel de "provedor" que se espera dele, exibir o ideal de comportamento generoso e expandir sua capacidade de influência.

Quanto mais bem-relacionado o chefe, portanto, maior sua capacidade de influência e maior também sua capacidade de receber ajuda no oferecimento de grandes festas. Ler os "mutirões de trabalhadores" guaná e a chefia eyiguayegui nessa chave, mais próxima das formas políticas ameríndias do que europeias, parece ser urgente nos estudos sobre os atuais Kadiwéu.

interior $e$ exterior, nobre $e$ não-nobre. A autora prefere hoje, à imagem do pêndulo, a da espiral (com. pessoal). 
Os dados trazidos pelas fontes deixam claros os processos de (auto-)construção da chefia e da nobreza: o "buen numero de pruebas y hazañas”, que Sánchez-Labrador considerava a forma de "ascenção" à nobreza em outras nações sul-americanas mostrase operante também entre os Eyiguayegui e os Kadiwéu. Mas, como afirmado no ínicio deste capítulo, há também certa dose de "hereditariedade" da chefia (embora esse não seja o melhor termo a ser utilizado). Os niniotagi são aqueles que têm que se esforçar para trazer os cativos e capitãs guaná para dentro de seus toldos (de modo a construírem e/ou afirmarem sua nobreza) e, ao mesmo tempo, que detêm as "histórias de fazer nomes”, ou os conhecimentos necessários para a existência dos Kadiwéu ${ }^{98}$. Nessas histórias, cujos protagonistas são ancestrais das famílias de capitães atuais, narra-se o surgimento (no exterior, diga-se de passagem) dos nomes dados a capitães e seus cativos. Sem a continuidade desses nomes - que estão nas mãos das famílias nobres desde quando foram "apanhados" por seus antepassados míticos, segundo eles próprios - o "sistema do índio" e os saberes kadiwéu não poderiam ser transmitidos de geração em geração ${ }^{99}$. Os modos de saber kadiwéu, que os constituem enquanto tal, estão, nesse sentido, nas mãos da nobreza e essa responsabilidade parece ser o grande "encargo" dos niniotagi.

Para entender melhor essa aristocracia, porém, precisamos questionar a concepção de "nobreza" como atrelada exclusivamente ao masculino: o fato de que os homens nobres faziam a guerra, cativavam crianças estrangeiras e se casavam com as "senhoras" guaná, trazendo-as para o interior das tolderias, precisa ser analisado em conjunto com os modos femininos de construção da chefia e da nobreza. Desde Fortes, os estudos de parentesco ganharam força por evidenciar a centralidade dos homens na passagem do âmbito doméstico para o público, da família para a sociedade, da natureza para a cultura. As mulheres, nesse modelo, ficaram relegadas à paisagem natural, sendo responsáveis apenas pela procriação biológica da sociedade. Para seguir em direção contrária a esse paradigma é preciso mostrar como as mulheres, no âmbito da criação das crianças cativadas e da produção de corporalidades, estão tão presentes na construção da nobreza eyiguayegui quanto os homens: vimos que as pinturas corporais são parte essencial da nobreza das "donas" eyiguayegui, por exemplo.

Os dados trazidos pelas fontes, aliás, nos permitem ir além: ainda que afirmem reiteradamente que, enquanto os homens faziam a guerra, caçavam e se reuniam para definir questões políticas, as mulheres se ocupavam dos afazeres domésticos (ou seja,

\footnotetext{
${ }^{98}$ Pechincha (1994: 89).

${ }^{99}$ Lecznieski (2005: 114).
} 
cozinhavam, teciam, se dedicavam à confecção de cerâmica, etc.), eles mostram também que as mulheres, além de preencherem parte de seu tempo com essas ocupações, estavam presentes nas guerras e muitas vezes eram consideradas capitãs de tolderias inteiras. Ao mesmo tempo, as crônicas nos apresentam aos cudinas, homens que se vestiam "como mulheres" e faziam o trabalho reconhecido como feminino: teciam, produziam cerâmica e eram mestras na pintura corporal. Como discutirei no próximo capítulo, o confinamento de homens às posições "políticas" e "públicas" e de mulheres às "domésticas" não nos ajuda a entender as relações denominadas "hierárquicas", que também não são estáticas, como demonstrado. Para desestabilizar a polarização entre "nobres" e "escravos" consagrada pela crônica colonial é necessário, assim, desestabilizar também as oposições entre doméstico e político, feminino e masculino. 


\section{Capítulo 3. O que pode o corpo eyiguayegui}

"Assim que a menina menstrua avisa aos pais" ${ }^{1}$ Imediatamente, a niggana-ake"moça que dá a festa", como é chamada a menina púbere - submete-se a um jejum total que só tem fim no dia seguinte, ao anoitecer. Nesse momento, uma mulher que não é parente da menina entra no aposento para "pisá-la". A menina é deitada de bruços e coberta com um pano. A visitante, então, aperta-a com as mãos na altura dos rins. É necessário que essa mulher seja discreta e trabalhadora porque suas qualidades passarão para a dona da festa, e é preciso também que a moça seja pisada antes de o sol se pôr, para que ela não corra o risco de ficar cega.

Depois de ser pisada, a moça pode comer poucas quantidades de comida, geralmente se alimentando com arroz ou macarrão cozidos com pouco sal, sem nenhuma carne ou gordura. Ela não pode comer carne vermelha ou branca, alimentos gordurosos, ovo de galinha ou mel. A menina é aconselhada a ficar calma e a não se exaltar, pois ela corre o risco de se transformar em bicho. Durante os próximos dias (de três a sete), ela ficará em cima da cama, sem poder encostar os pés no chão, e sob o mosquiteiro. Se precisar sair da cama, ela é carregada. Mas ela tende a não sair durante esse período, ficando mesmo reclusa: a intenção é que não veja nenhum animal, como cachorros e galinhas, por exemplo.

No decurso dos setes dias de reclusão acontece, no pátio de sua casa, uma festa animada com violeiros e sanfoneiros, que chamam todos para participarem das comemorações. No amanhecer do último dia os descendentes dos cativos chegam cedo para ajudar na preparação da grande festa de encerramento. Forma-se um círculo de peles de cervos no chão, os "couros", e alguns criados saem para convidar os habitantes da aldeia para a cerimônia. Um deles se encarrega de organizar a festa, dividindo as tarefas: de acordo com seus mandos, alguns nibotagi irão sentar nos couros para beber e as mulheres cativas irão para dentro da casa da niggana-ake.

No interior da casa da menina uma mulher passa cinzas brancas ou talco no corpo da dona da festa, formando ricos desenhos em seus ombros e braços, além de pintar seus rosto com urucum ou batom vermelho e de ornamentá-la com todos os colares diponíveis. O vestido de chita que a menina veste é trocado por um pano quadrado enrolado por baixo das axilas: diz-se que essa é a maneira de vestir-se à moda

\footnotetext{
${ }^{1}$ A citação é de Siqueira Jr. (1993: 95). A seguinte descrição da Festa da Moça é feita majoritariamente com base nas descrições de Jaime Siqueira Jr. (1993), Mônica Pechincha (1994) e Claude Lévi-Strauss (1996), além dos comentários de Lezcniezki (2005).
} 
antiga. O clímax da festa acontece quando a moça é abanada por uma senhora mais velha, também considerada uma grande sábia. Ela é abanada com o abanico, um tecido de flanela vermelho dobrado em quatro e bordado com miçangas. Em suas pontas são colocadas moedas furadas, miçangas e dedais de metal. Ao abanar a menina púbere, a velha também canta os cânticos adequados à ocasião.

Depois de adornarem e abanarem a niggana-ake, as senhoras se dirigem para o lado de fora. Elas começam a guiar - com seus cantos que falam também de expedições de caça e guerra - os cativos que sentarão nos couros, apontando o lugar de cada um. Todos eles recebem um pedaço de pano e os amarram à cintura antes de sentar. Quando todos estão em seus lugares, a aguardente é servida aos bebedores, que então já podem bebê-la. A borracheira acontece ao som da música dos violeiros, sanfoneiros e cantadoras e, quando todos se embriagam, são carregados de volta às suas casas, pondo fim à festa da moça.

Figura 2 - Nigaana-ake na festa da moça

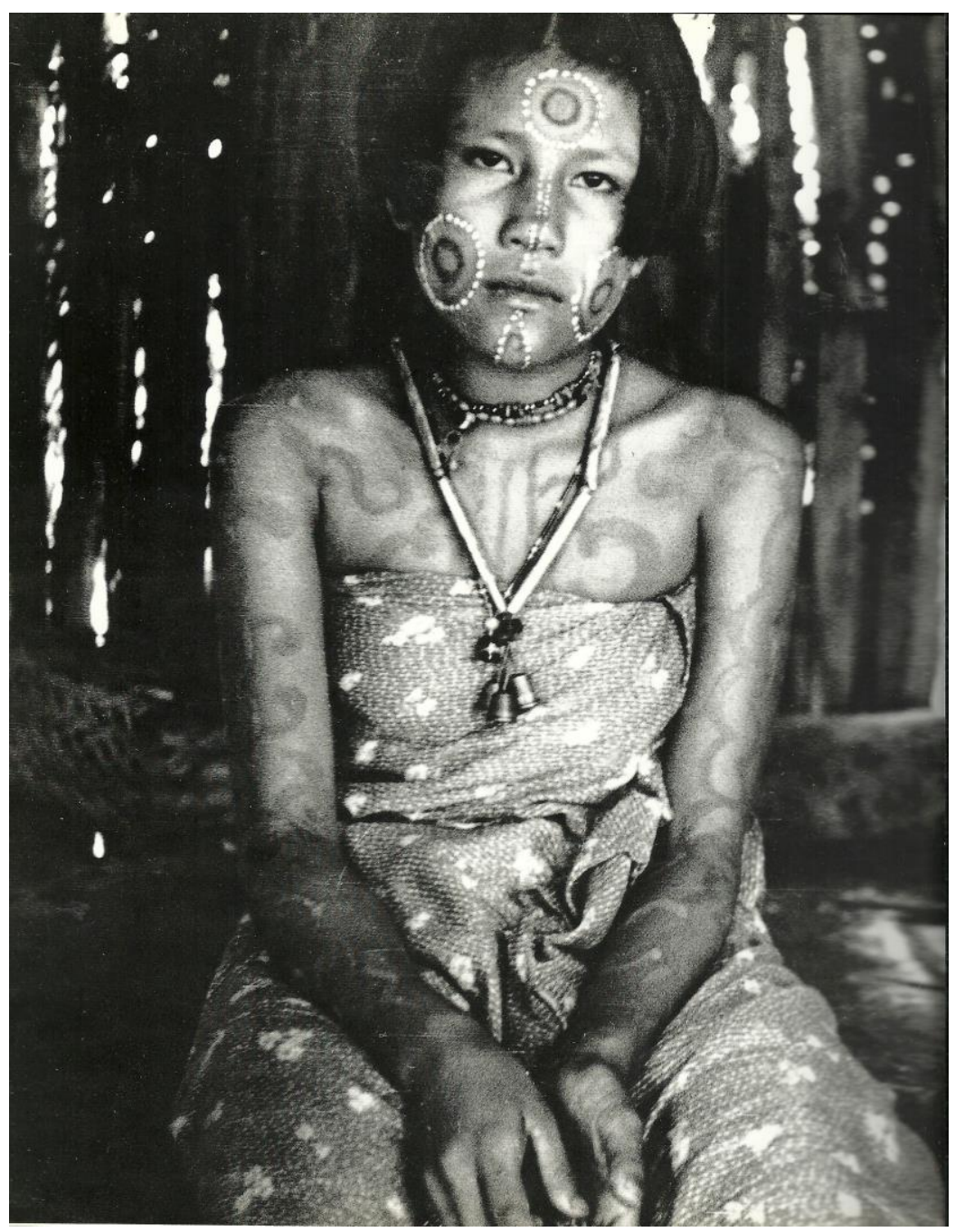

"Uma adolescente, cuja festa da puberdade era celebrada, tem o rosto, os ombros, o peito e os braços decorados. Dedais de costura formam os pingentes de seu colar". Fonte: Lévi-Strauss (1994: 78). 
Ao lado da festa do dia do índio, a festa da moça é a celebração mais importante realizada pelos Kadiwéu, sendo descrita desde as fontes coloniais até os dias de hoje ${ }^{2}$. Segundo Pechincha (1994: 156), é possível que nenhuma menina kadiwéu deixe de festejar sua menstruação, tamanha é a importância da cerimônia.

Não deixa de ser interessante o fato de que a nobreza eyiguayegui tenha sido remetida quase sempre, principalmente pelas fontes históricas, apenas à festa de criação do cacique descrita no capítulo anterior. As semelhanças entre as duas festas - a do cacique e a da "moça" - é evidente, ainda que a segunda não seja descrita como um momento de constituição da aristocracia. Em ambos os casos há, primeiramente, uma clara distinção (por meio das atribuições) entre os cativos e os anfitriões da festa. Em segundo lugar, há o esforço de construção de um corpo adequado à nobreza: no caso da festa de criação do capitãozinho, seu cabelo é cortado e seu lábio perfurado. Seu corpo é moldado também no estabelecimento de relações privilegiadas, vide o estabelecimento da "amizade" entre ele e o recém-nascido nibotagi. Já na festa da moça, espera-se que ela adquira certas qualidades por meio do contato com as anciãs respeitosas, trabalhadoras e sábias. Segundo Lecznieski (2005: 231), uma senhora observou a ela "que uma das coisas mais importantes era 'escolher bem' a pessoa que será responsável por 'abanar' a moça”. De acordo com a interlocutora da antropóloga, essa pessoa

deve ser escolhida com muito cuidado, pois acredita-se que suas características pessoais serão passadas à moça festejada. Idealmente, deve ser uma mulher não-parente, em especial uma 'velha que saiba cantar'.

Também lhe disseram que se tratava de uma "homenagem à moça" e que, na ocasião, ela era a "dona da festa”: toda a música e as bebedeiras têm espaço na casa da niggana-ake, assim como acontecia no toldo do capitãozinho recém-nascido. Ademais, a guerra está presente na festa da moça assim como na do pequeno cacique: os cânticos trazidos pelas senhoras narram grandes caçadas e expedições guerreiras. Por fim, a generosidade do capitãozinho está presente também na festa descrita no início deste capítulo: além de oferecer os festejos, a menina dá aos cativos "pedaços de pano" que remetem diretamente àqueles tecidos guaná ofertados pelo cacique aos participantes da festa do pequeno capitão.

Considero ser possível efetuar um paralelo entre essas duas festas, considerando-as momentos-chave para a construção de corpos eyiguayegui. Os elementos acima destacados - a centralidade do(a) capitão(ã), a presença da guerra e da

${ }^{2}$ Lecnieski (2005: 231). 
distribuição dos bens nas festas - já foram discutidos no capítulo anterior. Daqui em diante pretendo refletir acerca da construção, nessas festas e no cotidiano, de corpos diferenciados e da instabilidade destes corpos, que nunca se estabelecem como algo imutável. Iniciar este capítulo com a descrição da festa da moça tem, portanto, um duplo objetivo: chamar a atenção para o papel feminino (em conjunto com o masculino) na construção da nobreza eyiguayegui e evidenciar os processos que incidem sobre um corpo instável, construindo-o e adequando-o às suas funções (ou atribuições) cotidianamente. Sugiro ser essa instabilidade dos corpos o que permite movimentos percebidos como estranhos pelas fontes, como a "ascensão" de cativos à nobreza.

Quando questionados sobre a festa da moça, os interlocutores de Lecznieski respondiam que se tratava de um momento "muito especial e importante, em que moça

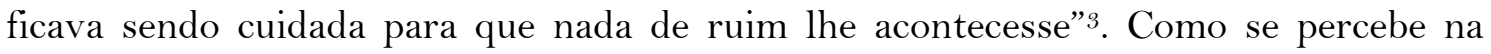
descrição, há uma grande preocupação em resguardar a menina, que está em um momento deveras perigoso: ela se abstém de comer qualquer carne ou gordura, não encosta no chão, não pode ver nenhum animal e nem ficar nervosa. Ao mesmo tempo, ela passa por processos que tentam "inserir” em seu corpo algumas qualidades: ao segundo dia do resguardo, ela é "pisada" por uma anciã e, mais tarde, é pintada de branco e vermelho, além de ser abanada. Também na festa de criação do cacique há processos de construção do corpo: tanto o corte de cabelo quanto a perfuração de seu lábio e lóbulos de suas orelhas parecem ir no sentido de fabricar um corpo específico, assim como o da moça púbere. Ademais, as descrições fazem perceber que o papel das velhas nos dois casos é de extrema importância: elas e as crianças protagonizam os atos centrais das festas. Na festa da moça, são elas que "passam" suas características à menina púbere, pintam seu corpo, ministram a bebedeira e cantam sobre a guerra e a caça. Na festa de criação do capitãozinho, são elas que dançam, amamentam o pequeno cacique e participam dos torneios de jogos de socos. Segundo as etnografias atuais, é nas festas que a "força das mulheres" eyiguayegui e kadiwéu, as "principais conhecedoras dos rituais" ${ }^{4}$, parece se mostrar com maior nitidez.

Todos esses elementos trazidos nas descrições das duas festas podem ser interpretados à luz das etnografias americanistas atuais e, mais especificamente, pelo debate ainda muito profícuo acerca da fabricação do corpo entre as populações ameríndias. Para entender melhor a constituição das diferenciações por estatutos nas tolderias eyiguayegui, bem como os movimentos de rearranjo desses estatutos,

\footnotetext{
${ }^{3}$ Lecznieski (2005: 231).
}

${ }^{4}$ Siqueira Jr. (1993: 99). 
precisamos primeiramente analisar os dados trazidos pelas fontes e etnografias sobre o corpo eyiguayegui. Vamos a eles.

Os corpos presentes nas tolderias são descritos pelas fontes coloniais como essencialmente diferentes: de acordo com seus autores, de um lado estariam os nobres eyiguayegui e, de outro, os "escravos" estrangeiros. Vejamos com essa diferença é construída pelos europeus tomando sua apresentação dos ornamentos e pinturas corporais como exemplo.

Segundo as fontes, homens e mulheres eyiguayegui aguçavam todos os dentes com lixas e depilavam todos os pelos do corpo - costumes considerados prova de sua humanidade ${ }^{5}$ - e 'tratavam, com repugnância, de 'irmãos de avestruz' os europeus de olhos peludos"6. Segundo Rodrigues do Prado (1795: 29), as mulheres

[a \nda[va $\ m$ envoltas dos pés até o pescoço em um grande panno de algodão, que [eram] tintos de côr avermelhada com listas brancas, negras e roxas: as mais aceiadas traz[ia $\rceil \mathrm{m}$ nelles muitas rodinhas de conchas, postas com a madrepérola para fora e seguras com linhas, formando diferentes vistas.

Já os homens adultos, guerreiros ou não, usavam cocares e braceletes de penas nos tornozelos e pulsos. Usavam também

[...] cinta de algodão tinto da largura de um palmo, e depois que tiveram comunicação com os Hespanhóis se cobr [ia $] \mathrm{m}$ de contas de diversas cores, com as quaes faz [ia $] \mathrm{m}$ diferentes lavores. $\mathrm{T}[$ inham $] \mathrm{o}$ beiço de baixo furado, e nelle [era] metido um páo da grossura da metade de uma pena de escrever, e do comprimento de um terço de palmo; os mais ricos traz [ia $] \mathrm{m}-$ no de prata; e nas orelhas traz $[\mathrm{i} a] \mathrm{m}$ meias luas de prata (...) (Rodrigues do Prado 1795:29).

Os homens usavam, nos tornozelos e pulsos, contas azuis e tubinhos de prata, no caso dos nobres ${ }^{7}$. Sobre o fundo unicolor de seus corpos - por vezes preto e por vezes vermelho - eles pintavam as estrelas, a lua e o sol com tinta branca feita da farinha da palma namogoligi ${ }^{8}$.

As pinturas corporais femininas eram bem diferentes das masculinas, ainda que ambas fossem feitas pelas mulheres. Feitas de arabescos largamente reconhecidos e documentados na literatura antropológica, principalmente por Lévi-Strauss (1996;

\footnotetext{
${ }^{5}$ Sánchez-Labrador ([1770-1776], v. I: 247).

${ }^{6}$ Lévi-Strauss (1996: 191).

${ }^{7}$ Sánchez-Labrador ([1770-1776], v. I: 351$)$; Taunay (1934:19); Boggiani ([1895]: 131).

${ }^{8}$ Sánchez-Labrador ([1770-1776], v. I: 284-5).
} 
2012) $)^{9}$, levavam horas para serem finalizadas, por conta dos detalhes contidos em suas "líneas, dibujos y celocías ${ }^{10 "}$. Elas podiam cobrir o tronco inteiro e o rosto, ou podiam ser feitas apenas em torno da boca. Algumas vezes, essas pinturas são descritas mais como tatuagens:

As mulheres [...] mandam-se picar com espinhos na testa, formando linhas que principiam na raiz do cabelo e vem acabar sobre as pálpebras dos olhos, na face e na barba, onde formam um xadrez, e dão logo com tinta de jenipapo, com o que se conservam toda a vida pintadas de côr cinzenta; e as donas também fazem nos braços uns quadrados, sofrendo em todas estas ocasiões cruéis dores (Rodrigues do Prado 1795:29).

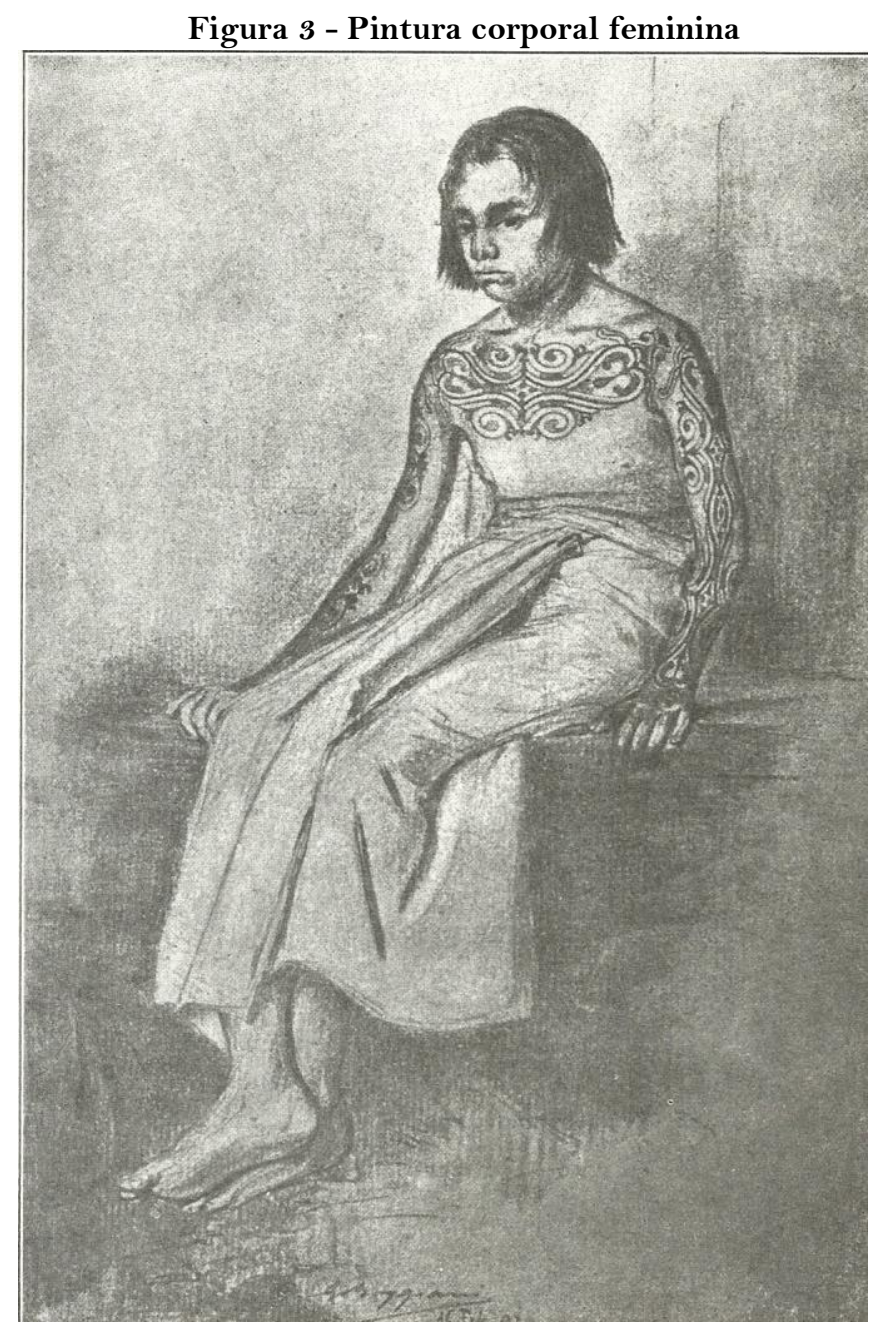

“Jovem caduveo”. Fonte: Boggiani ([1895]: 192)

\footnotetext{
${ }^{9}$ As pinturas faciais e corporais kadiwéu são objeto de vários estudos. Para mais descrições e análises sobre essas pinturas, ver Siqueira Júnior (1992a; 1992b) Padilha (1996); José da Silva e Kok (2014); Lecznieski (2005) e Duran (2016; 2017).

10 A citação é de Sánchez-Labrador ([1770-1776], v. I:284). O termo celocía vem da arquitetura e se refere à tábua utilizada para fechar vãos, mas que ao mesmo tempo é vazada para permitir a entrada de luz. As celosías são, muitas vezes, trabalhadas com linhas que se encontram e desencontram, formando desenhos.
} 
Figura 4 - Pintura facial feminina

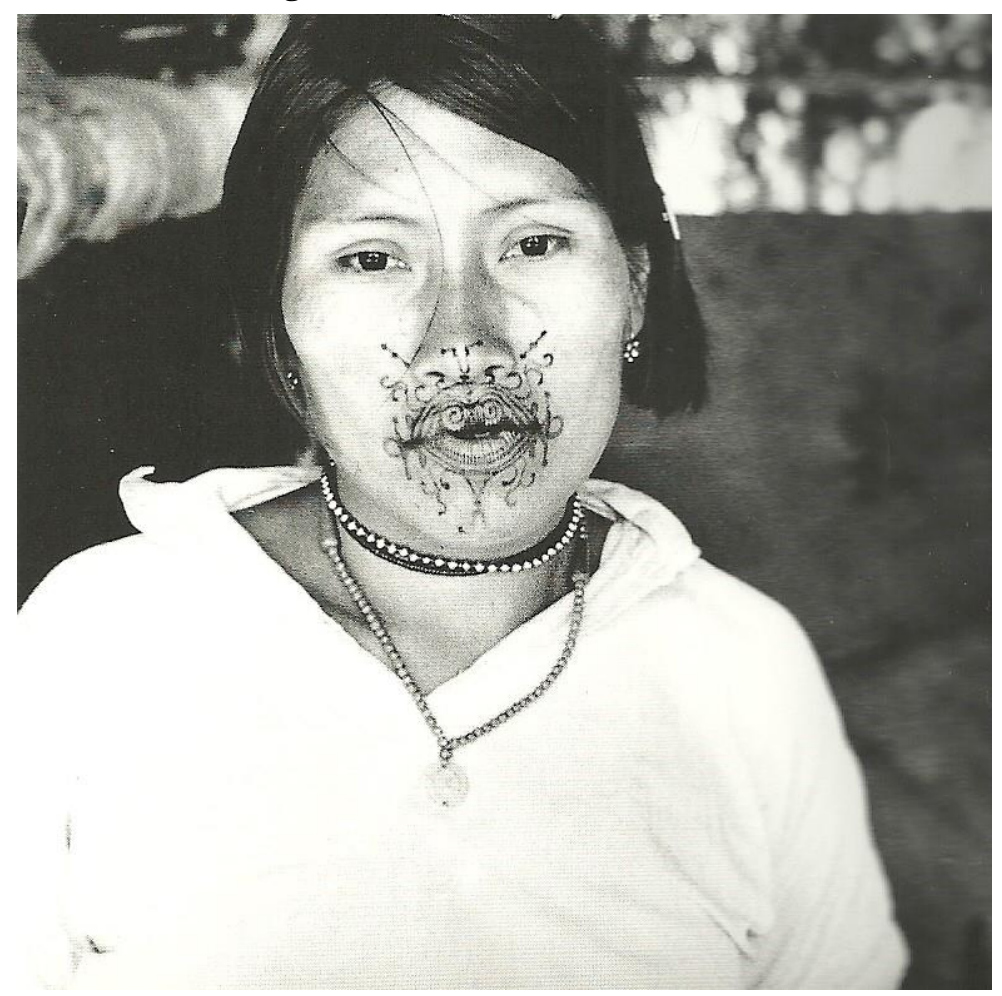

Fonte: Lévi-Strauss (1994: 74)

Figura 5 - Pintura facial de uma "escrava" chamacoco

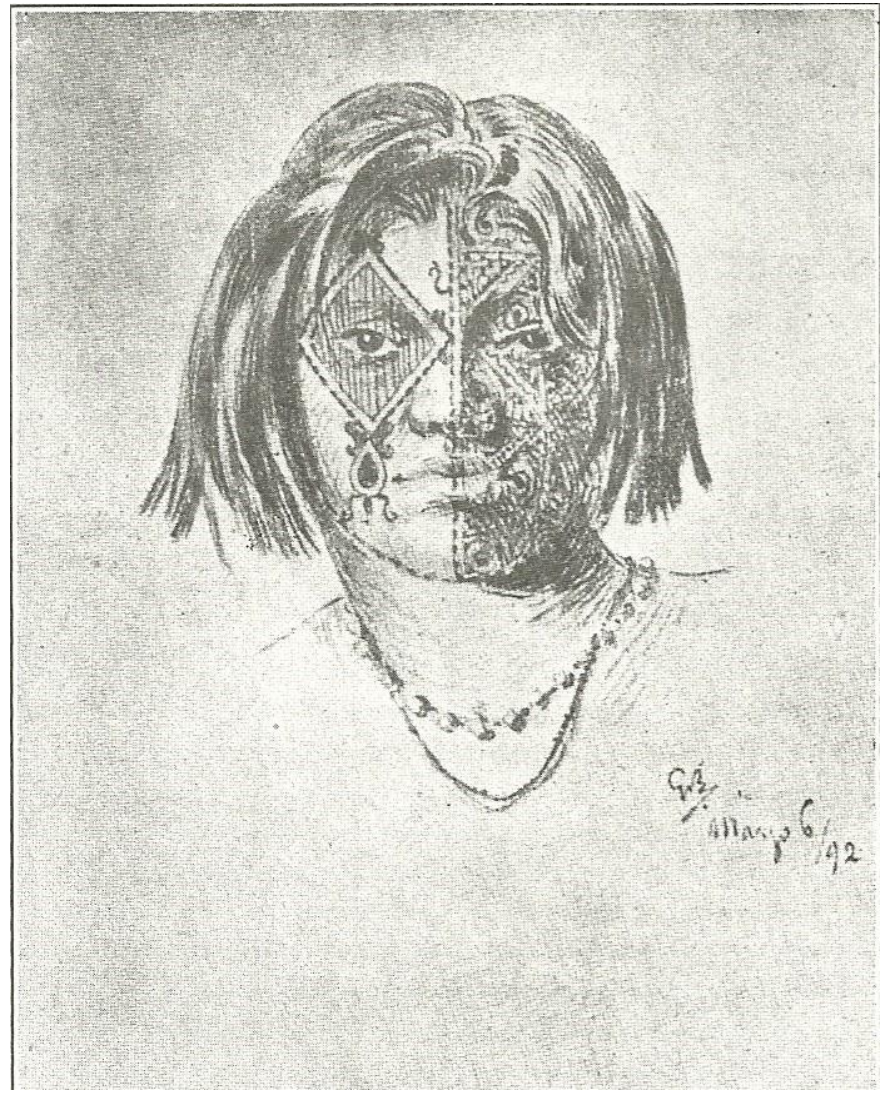

"Retrato de minha mulher. De um esboço a lápis". Fonte: Boggiani ([1895]: 192). 
Ao refletir acerca das pinturas faciais e corporais kadiwéu, colocando-se a questão de "para quê serve a arte caduveo?", Lévi-Strauss (1996: 183) aventa a possibilidade de que o principal motivo das pinturas realizadas pelas mulheres seria a de que elas "conferem ao indivíduo sua dignidade de ser humano; operam a passagem da natureza à cultura, do animal 'estúpido' ao homem civilizado”. Indo ainda mais longe, o antropólogo afirma que por meio de sua arte (e também pelo aborto e pelo infanticídio, como veremos adiante) os Eyiguayegui expressavam seu horror pela natureza e proclamavam seu desprezo pelo "barro de que somos feitos" 11.

As afirmações de Lévi-Strauss acerca da "dignidade de ser humano" e do "barro de que somos feitos" acabam por colocar questões complicadas que já foram profundamente discutidas ${ }^{12}$ e que podem aqui ser apenas resumidas. No momento, basta dizer que, como indicam dados etnográficos provenientes dos mais variados contextos americanos, o que mais importa nas filosofias ameríndias não é o pertencimento (ou não) a uma categoria genérica de humanidade, e sim a construção, pelas relações, de um determinado tipo de corpo e, consequentemente, do ponto de vista de cada sujeito ${ }^{13}$. As populações indígenas, como afirmam as análises americanistas atuais, parecem não conceber que todos nós sejamos feitos do mesmo barro: todos nós temos corpos diferentes, não havendo, portanto, uma natureza universal em relação à qual os Eyiguayegui pudessem manifestar seu desprezo.

Ainda que tenha esbarrado em conceitos hoje considerados deslocados na reflexão da etnologia americanista, o etnólogo francês parece ter percebido a real intenção das ornamentações corporais eyiguayegui e kadiwéu: elas servem, entre tantas outras coisas ${ }^{14}$, para fabricar corpos "de gente", ou corpos propriamente eyiguayegui. Ao lado do hábito de depilar todos os pelos do corpo e utilizar determinados ornamentos, a pintura realizada pelas mulheres parece poder ser entendida como uma evidência de seu pertencimento a uma comunidade cujos modos de vida são semelhantes. Talvez por isso as pinturas tenham sido, muitas vezes, entendidas como uma forma de diferenciação entre os niniotagi e os nibotagi.

De acordo com Lévi-Strauss (1996: 183), esse seria o segundo objetivo da arte kadiwéu: ela expressaria a hierarquia dos status por meio de diferenças no estilo e na composição. Também Pechincha (1994: 52) afirma ser a pintura corporal uma forma de

\footnotetext{
${ }^{11}$ Lévi-Strauss (1996: 178).

12 Para alguns exemplos da discussão sobre "humanidade” e "animalidade”, "natureza” e "cultura”, ver Viveiros de Castro (1996; 2002) e Vilaça (2005).

13 Vilaça (2002: 351).

${ }^{14}$ A tese recente de Duran (2017), que se debruça sobre os desenhos das pinturas corporais kadiwéu, demonstra como cada motivo tem diferentes nomes e propósitos, relacionando-se à sua mitologia.
} 
distinção dos niniotagi. Segundo a antropóloga, que tem como base os escritos de Sánchez-Labrador, "os Mbayá usavam grande parte do dia para o trabalho de se pintarem enquanto os criados se encarregavam dos trabalhos domésticos cotidianos”. De acordo com essa lógica, os "nobres" eyiguayegui podiam se pintar porque eram "livres dos trabalhos subalternos"15, tendo tempo de sobra para se ornamentar, enquanto seus "escravos" ocupavam-se apenas com os trabalhos inferiores, pouco se engajando no embelezamento de seus corpos.

Essa visão é encontrada em grande parte das fontes. Sánchez-Labrador ( $[1770-$ 1776], v. I:287), por exemplo, chama atenção para a diferença entre os adornos utilizados pelos "escravos", que seriam reconhecíveis pelo seu "desalinho e fealdade" em contraposição à beleza artística das pinturas e adornos eyiguayegui. É interessante trazer aqui a diferenciação efetuada pelo missionário entre as pinturas das mulheres "nobres" e "plebeias":

Las mujeres tienen pinturas pasajeras y permanentes. Las que son de la plebe se graban desde la frente hasta sobre las cejas con unas rayas negras que en su uniforme desigualdad remedan las plantas de un órgano. Otras añaden grabarse todo el labio inferior hasta la barbilla. Las cacicas y mujeres de capitanes se abren los brazos con el mismo artificio formando muchos cuadrángulos y triángulos desde el hombro hasta la muñeca. Esta es una de las señales indelebles que caracterizan su nobleza. Rarísima de estas señoras permite grabaduras de la cara; estas son como la marca de sus inferiores y criadas. (SánchezLabrador [1770-1776], v. I: 285, grifos meus).

Fundamentado nos diários do jesuíta, Santos-Granero (2009: 122, tradução minha) afirma que a diferença entre as "pinturas passageiras e permanentes" citadas por Sánchez-Labrador seria a de status. Segundo o antropólogo, as "mulheres guaicurú de alto nível não tatuariam seus rostos em nenhuma circunstância, pois as tatuagens faciais seriam consideradas 'marcas dos servos e das pessoas inferiores'”.

Sobre as pinturas corporais masculinas, Sánchez-Labrador escreve:

Muchos pobres criados no merecen el notique nibadena [urucum], y menos la harina de la palma namogoligi, de cual forman las estrellas. Estos suplen la falta con carbón molido; y se tiñen tan feamente, que parecen asenas apagadas. Así denegridos, suelen rodear a las cabezas unas plumas de avestruz pardas sin más arte que atarlas punta con punta, para que asienten en forma de guirnalda. Con esto añaden a la fealdad desaliño (Sánchez-Labrador [1770-1776], v. I: 286).

A diferença entre as pinturas de niniotagi e nibotagi, porém, é desafiada por outros relatos. As descrições de pinturas passageiras e permanentes, por exemplo, podem se referir tanto às "donas" quanto às "escravas": o processo de tatuagem narrado

\footnotetext{
${ }^{15}$ Lévi-Strauss (1996: 191).
} 
por Rodrigues do Prado na citação acima é efetuado no rosto de uma "senhora", o que contraria a afirmação de Sánchez-Labrador (e, consequentemente, de Santos-Granero) de que apenas as cativas tinham pinturas indeléveis. $\mathrm{O}$ fato de a pintura ser corporal ou facial também não parece indicar nobreza ou "escravidão": tanto uma quanto a outra eram realizadas bem "democraticamente" 16 . No mais, o processo da pintura também não era realizado separadamente: Boggiani ([1895]: 123), por exemplo faz uma bela descrição de uma capitã desenhando o corpo de duas "escravas" suas. Mesmo a diferença entre o jenipapo e o carvão (considerada por Sánchez-Labrador uma prova da inferioridade dos cativos), é explicada pelo italiano por motivos técnicos: segundo o comerciante, que era também artista, o jenipapo e o carvão eram usados ao mesmo tempo pois, ao passo que o carvão aparece na pele instantaneamente, o jenipapo leva um tempo para se mostrar. A técnica usada pelas mulheres (tanto nobres quanto “escravas”) era a de fazer o desenho primeiramente com o carvão e depois contorná-lo com o jenipapo, que fica por muito mais tempo na pele ${ }^{17}$. Ademais, veremos adiante que o carvão é utilizado atualmente na pintura dos guerreiros, não sendo relacionado à inferioridade. Não parecia haver, nesse sentido, uma inferioridade das cativas e cativos que os excluíssem das melhores pinturas: segundo Lecznieski (2005: 175), a pintura corporal kadiwéu é, na verdade, "democrática", pois "mais do que exprimir e manter a hierarquia social, as pinturas funcion[am] como uma prática que, sendo livre à todos, une a todos, kadiwéus e não-kadiwéus, nobres e cativos, como uma coletividade”.

Torna-se claro, portanto, que a diferenciação (em termos hierárquicos) das pinturas nobres e não-nobres se deve mais à visão europeia do que às relações dos Eyiguayegui com seus cativos. Aliás, essa hierarquização efetuada pelas fontes ultrapassa o campo da arte e chega ao domínio da conformação física. Se de um lado os "índios cavaleiros" eram tidos como "hombres altos, hermosos y guerreros" e como "mujeres muy hermosas" 18 , os cativos são descritos como mais magros e menores em altura. E as comparações não param por aí: Guido Boggiani ([1895]:133) chega a diferenciar os Eyiguayegui, que seriam "compostos e limpos", de seus "escravos" chamacoco, que teriam "hábitos de desordem e incúria". O italiano demonstra diversas vezes em seus diários a predileção que tem pelos nobres eyiguayegui em detrimento aos Chamacoco, que segundo ele tinham o costume de mentir a todo o momento: "a

\footnotetext{
${ }^{16}$ Lecznieski (2005: 175).

17 Boggiani ([1895]: 124). Note-se que a mistura de genipapo com carvão para a pintura corporal é extremamente frequente nas terras baixas sulamericanas. Ver, por exemplo, http://www.indiosonline.net/pintura-tupinamba.

${ }^{18}$ Schmidel ([1553]: 79).
} 
mentira é entre eles de tal forma em uso que ninguém mais faz caso disso"19. As disparidades na aparência e no caráter são sempre mencionadas, mesmo que sutilmente: o elogio constante à bravura e à postura dos "nobres" é sempre acompanhado de um comentário sobre a inferioridade corporal e comportamental dos "escravos", definidos como ainda mais selvagens que seus "senhores".

De onde viria, então, a diferença corporal observada pelos autores das fontes, se não de uma gradação hierárquica? A próxima seção pretende apontar alguns caminhos para o entendimento dessas diferenças, tendo como foco a construção dos corpos nobres tal como descrita pelas fontes. É importante notar, desde já, que as descrições da corporalidade aristocrata se misturam àquelas dos corpos eyiguayegui, sendo por vezes impossível saber se os dados se referem aos niniotagi ou aos "comuns", por exemplo. Evidentemente, este é um dado a ser considerado pela análise, uma vez que a dificuldade na distinção entre "nobres" e "comuns" já diz bastante sobre a nobreza chaquenha. O que parecia acontecer era que o corpo ideal eyiguayegui era visado por todos, mas era alcançado apenas por alguns - os nobres. Os dados apresentados abaixo, portanto, devem ser lidos como pistas para o entendimento de como era construído o corpo adequado eyiguayegui.

\subsection{Corpos nobres}

Quando lidas com atenção, as citações sobre os ornamentos de mulheres e homens eyiguayegui apresentadas acima nos oferecem diversas pistas, que parecem evidenciar que corpos nobres eram aqueles construídos majoritariamente por elementos estrangeiros. As mulheres eyiguayegui, segundo Rodrigues do Prado, "andavam envoltas" em "um grande panno de algodão", panos que provavelmente vinham das aldeias guaná, sendo tecidos pelas unati. Ainda que as fontes não afirmem a origem das conchas e madrepérolas usadas pelas donas, elas pareciam estar envolvidas na mesma rede de trocas que fazia circular não apenas pelo Chaco, mas também pelos Andes e pela região do atual Mato Grosso do Sul, os "tubinhos de prata" e as contas adquiridas depois que os povos da região "tiveram comunicação com os Hespanhóis” 20. No mais, o cocar utilizado pelos "senhores" é também descrito por um interlocutor de Pechincha (1994: 157) como oriundo de fora: de acordo com sua narrativa, o cocar foi roubado dos Guarani-Kaiowá por um renomado chefe eyiguayegui (ver anexo I).

\footnotetext{
${ }^{19}$ Boggiani ([1895]:186).

${ }^{20}$ Estas redes de troca foram brevemente apresentadas no primeiro capítulo.
} 


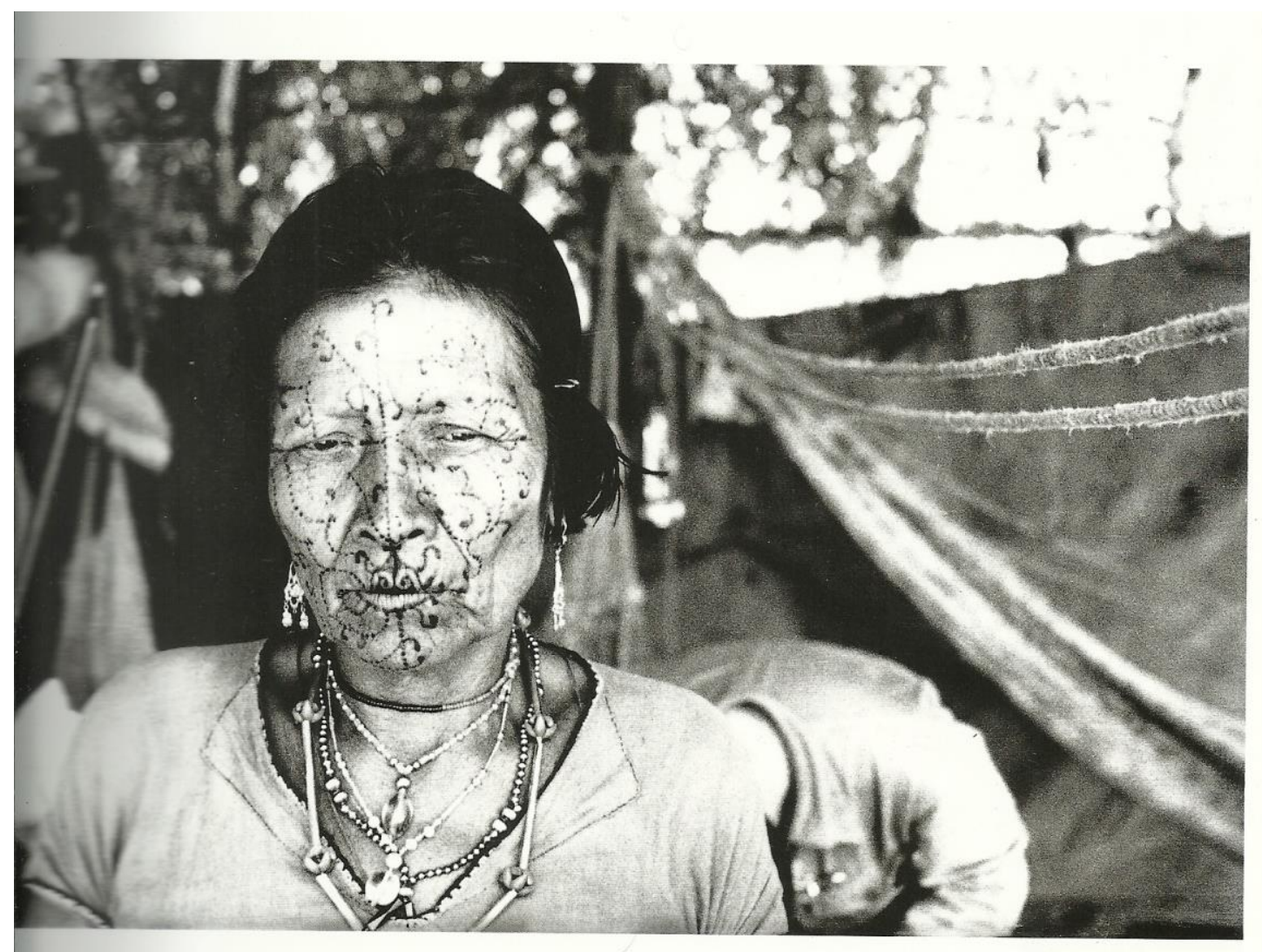

"Velhas mulheres, extraordinárias virtuoses, ornadas de jóias feitas de peças de prata marteladas inventam composições cuja liberdade quase não leva mais em conta os traços do rosto humano". Fonte: Lévi-Strauss (1994: 77).

A ornamentação das orelhas e dos lábios dos "senhores" (os nobres, como afirma Rodrigues do Prado, tinham "o beiço de baixo furado, e nelle [era] metido um páo da grossura da metade de uma pena de escrever" e traziam "nas orelhas [...] meias luas de prata”) não foi muito descrita pelas fontes e nem pelas etnografias atuais. Sabemos apenas que, desde criança, os nobres já levavam esses ornamentos consigo: na festa do capitãozinho já descrita, seus lábios e lóbulos das orelhas eram perfurados e discos auriculares e labiais eram inseridos nas perfurações. É interessante pontuar que por vezes, em outros contextos etnográficos ameríndios, os ornamentos se relacionam com o "significado simbólico” desses órgãos²1. Entre os Kisêdje (ou Suyá), por exemplo, o ato de ornamentar orelhas e boca está ligado à importância social do ouvir e do falar, ações sociais por excelência ${ }^{22}$. Os chefes kisêdje - os homens ideais, que precisam ter ótima oratória e ser bons ouvintes - são os que mais investem nesses tipos de

\footnotetext{
${ }^{21}$ Seeger (1980: 45).

${ }^{22}$ De maneira parecida, Belaunde (2006: 227) afirma que "[n] a área do Xingu, por exemplo, os meninos na puberdade soltam sangue das orelhas como um meio de ampliar suas capacidades de audição e entendimento moral".
} 
ornamentos de modo a desenvolver cada vez mais as características que são deles esperadas $^{23}$. Infelizmente, os poucos dados sobre a ornamentação do capitãozinho e dos nobres eyiguayegui não nos permitem fazer nenhuma afirmação nesse sentido, mas considero provável que suas perfurações não possam ser tomadas como "puramente" estéticas - até porque entre os povos ameríndios a estética e a política, o belo e o correto, andam de mãos dadas.

Os indícios levantados por esses dados fazem pensar que a beleza dos corpos nobres - beleza que vinha da "origem" exterior de seus ornamentos e de sua correspondência a certas exigências do que seria um corpo adequado -, reconhecida por grande parte das pessoas nas tolderias, era também percebida pelos autores das fontes, que a entendiam em termos hierárquicos e nesses termos a expressavam. Não há nenhum indício, porém, de que a beleza dos corpos nobres os fizesse superiores a outros; o que parecia acontecer era que, sendo a nobreza em grande parte constituída, como discutido no capítulo anterior, por relações com um Fora (ou seja, com inimigos ou não-aliados contextuais), para poder mantê-la, os niniotagi precisavam com elas construir seus corpos.

Essa construção corporal, por sua vez, ganhava destaque em momentos em que a relação com o Fora era exarcebada, como nas festas e nas expedições guerreiras. Aliás, os corpos nobres pareciam ser consagrados a estes momentos e a festa de iniciação dos capitãezinhos é um exemplo disso. Quando os meninos completavam doze anos, suas famílias ofereciam uma festa em que eles eram pintados de vermelho e vestiam "cuantas galas de plumas, cuentas y metales" tinham. Depois de ter seus cabelos raspados em duas coroas, os pequenos caciques tocavam um tambor e cantavam durante toda a noite, só parando ao pôr do sol do dia seguinte, quando tinha início a cerimônia de perfuração: o unigene (xamã eyiguayegui) transpassava o membro do menino com um dente de onça e, com o seu sangue, cobria todo o corpo do iniciado, que não podia demonstrar nenhum sinal de dor se quisesse ser reconhecido como "soldado". Depois da cerimônia, o menino dava tudo o que estivesse vestindo aos presentes e oferecia uma solene borracheira ${ }^{24}$.

É interessante pontuar, mais uma vez, que os elementos capturados de fora parecem estar em cada detalhe da festa. Um dos bens doados, por exemplo, era uma pulseira de prata proveniente da rede trocas que chegava aos Andes, como afirmado. Além disso, havia a perfuração peniana, que era realizada com o dente de "onça”. Esse

\footnotetext{
${ }^{23}$ Seeger (1980: 55).

${ }^{24}$ Sánchez-Labrador ([1770-1776], v. II:8).
} 
tipo de intervenção não é exclusiva dos Eyiguayegui: também os Mocovi (outro grupo de língua guaicurú hibitante do Chaco) as realizavam, segundo Perusset e Rosso (2009: 70). De acordo com as autoras, esse tipo de perfuração "estaba relacionado con el contagio de las cualidades del animal con el que se realizan las mismas".

No mais, o derramamento de sangue causado pela perfuração do membro do menino não era exclusivo aos meninos púberes: os guerreiros já experientes também passavam por esse tipo de prova. Segundo Sánchez-Labrador ([1770-1776], v. II: 8), a reputação dos soldados era provada pela corrida por ele relatada: ao amanhecer, os competidores, assim como os iniciados, se pintavam de vermelho e colocavam plumas em torno de seus tornozelos e braços. A corrida era realizada a uma certa distância da tolderia e, quando eles iam chegando se faziam “[ [...] crueles sangrias em varias partes del cuerpo". Com o dente de onça, se perfurava "de parte a parte las pantorillas junto al talón del pie y cerca de las corvas", além dos braços e na cintura. Segundo os interlocutores do padre, as sangrias eram realizadas para que os soldados não sentissem o cansaço: "esta es una de las pruebas del valor. Porque si el herido aguenta sin hacer movimiento, se acredita de guapo, y es acreedor a los mayores honores digno de un soldado Eyiguayegui”. De maneira parecida, Lecznieski (2005: 191) afirma que, “quando o 'padre' (xamã) previa alguma calamidade ou ataque de inimigos, os homens faziam 'sangrias' no corpo como forma de prevenir e afugentar os males previstos". Sobre os Abipon, grupo chaquenho também falante de língua guaicurú, Colini (1975: 259) escreve que

\begin{abstract}
[s]ão pródigos em verter o seu sangue, tanto para obter glória como para adquirir saúde, porque nas reuniões públicas que realizam por pândega pungem cruelmente os seus peitos, braços e a sua língua com um maço de espinhos ou com ossos cortantes do dorso do jacaré, de modo a fazer sair sangue em abundância. Mostram, em fazer isso, emulação de um com outro para ganhar a reputação de bravura e a fim de que estas feridas possam torna-los menos temerosos de verter o sangue nos combates com o inimigo e possam tornar as suas peles impenetráveis, cobrindo-a de cicatrizes.
\end{abstract}

Desde as descrições das fontes até as análises antropológicas atuais, as escarificações e perfurações são entendidas como maneiras de se provar a bravura e a ausência de medo e também como uma forma de adquirir certas qualidades de seres outros, como afirmaram Perusset e Rosso sobre os Mocoví. Como vimos, de maneira parecida, o unigene eyiguayegui utilizava um dente de onça para fazer a perfuração no menino púbere, parecendo ser possível afirmar que as perfurações dos dois grupos seguiam lógicas semelhantes. No mais, sugiro que as perfurações e sangrias podem ser também vistas como maneiras de os "soldados" deixarem correr o sangue acumulado, 
tornando-se consequentemente mais fortes, como sugere Belaunde (2008: 227) a respeito dos povos xinguanos.

Por fim, é necessário fazer um último apontamento antes de seguir com a descrição sobre a guerra eyiguayegui. Note-se que em muitos momentos, tanto na festa de criação do capitãozinho, quanto nas festas da moça e de iniciação do menino as pinturas realizadas são feitas com o urucum, da cor vermelha. No primeiro caso, são as velhas que se pintam de vermelho; no segundo, tanto a nigaana-ake quanto a velha que a ornamenta são pintadas dessa cor, com urucum ou batom; no terceiro caso o sangue que sai da perfuração do menino acaba por cobrir seu corpo, deixando-o da mesma tonalidade. Todas essas descrições parecem apontar para o fato de que o vermelho é usado em momentos em que a expansão, ou a abertura ao outro, é evidenciada e mesmo buscada: nos momentos em que os corpos estão pintados de vermelho, eles parecem fazer um movimento centrífugo, em direção ao exterior, que pode ser associado ao ímpeto guerreiro. Mas o mesmo se pode dizer da pintura negra de jenipapo, em outros contextos. Este ponto, porém, será desenvolvido adiante. Por ora, concentro-me na descrição das expedições guerreiras eyiguayegui, centrais para a constituição da nobreza e, portanto, da diferenciação entre os corpos nas tolderias.

\subsubsection{Expedições guerreiras}

Si han de emprender alguna expedición contra los que ellos llaman sus enemigos, un día o dos antes tocan incesantemente un tamborete en el toldo del capitán que alista gente. Los que quieren probar fortuna se le agregan de aventureros: pero a ninguno se obliga á la marcha. El sonido del tamborete hace las veces de convocatoria y como de publicación de la guerra. Salen a esta, no en compañía arreglada, sino ya uno, ya otro, como les da la gana. Así caminan hasta el sitio que llevan premeditado para el asalto furtivo (SánchezLabrador, [1770-1776], v. I:307).

Por mais que fossem temidas por europeus e bandeirantes, as expedições guerreiras eyiguayegui eram muitas vezes consideradas desorganizadas pelos autores das fontes, que afirmavam que elas não chegavam a constituir - por conta da suposta falta de disciplina de seus "soldados" - um exército propriamente dito ${ }^{25}$. A chamada que partia de um capitão agregava guerreiros não por conta de uma razão política consolidada, segundo os docuemntos, mas simplesmente pela sede daqueles índios pelo sangue. Os "soldados", como afirma Sánchez-Labrador, iam para a guerra apenas se

\footnotetext{
${ }^{25}$ Os chamados de guerra podiam se restringir apenas a uma ou duas tolderias, ou podia chegar a reunir "parcialidades" inteiras, dependendo do inimigo. Nesse caso, cada toldo prosseguia “[...] com total independência”, trazendo cada um seu próprio capitão e não se subordinando aos chefes de outras parcialidades (Sánchez-Labrador [1770-1776], v. I:309).
} 
quisessem e durante os ataques não deviam obediência a ninguém. Sua única motivação seria a de provar seu valor. Mesmo a excursão às terras inimigas era desordenada, segundo as fontes: os habitantes dos diferentes toldos partiam no momento que achassem melhor e seguiam apenas suas próprias inclinações durante os ataques.

A investida final era geralmente realizada pela manhã, após uma noite de vigília, em que alguns guerreiros observavam as esteiras inimigas à procura de sinais de resistência. Quando não os encontravam, os outros "soldados" eram avisados e então, ao raiar do dia, todos se lançavam à tolderia estrangeira. Todos os movimentos eram coordenados pelos músicos - flauteiros que, de acordo com Sánchez-Labrador ([1770-1776], v. I:309), eram imprescindíveis na guerra por avisarem o “[ [...] número, calidad y movimientos del enemigo". O berrante ${ }^{26}$ também era utilizado, segundo os autores, para causar medo no adversário.

A destreza na montaria dos cavalos era o principal motivo da supremacia eyiguayegui, de acordo com a documentação colonial, não apenas porque a força dos equinos destruía as tolderias inimigas com imensa facilidade, mas também por conta da interação entre estes e os "soldados", muito bem descrita no relato de Taunay (1931:52) a seguir:

\begin{abstract}
Sua táctica consiste em reunir grandes manadas de cavallos chucros que tocam á sua frente sem cavaleiros, misturando-se entre os últimos animaes soltos. E para escapar á vista do inimigo praticam um ardil que basta para dar idéa de sua agilidade e destreza quando a cavallo. Cada cavaleiro, apoiado apenas no estribo agarra-se ás crinas do animal com a mão direita e mantém-se deitado, assim suspenso, ao longo do corpo da montaria, conservando tal attitude até que chegue ao alcance da lança. Nesse momento põe-se erecto sobre a sella e combate com vantagem no meio da desordem causada pelo ataque tumultuário ${ }^{27}$.
\end{abstract}

Segundo Rodrigues do Prado (1795:39), ao mesmo tempo em que comandavam os cavalos com maestria, os índios manejavam também a maça ("um páo de quatro até cinco palmos de comprido e uma polegada de diâmetro"), a lança (que era "pouco maior de grossura e dezoito palmos de comprimento”), o terçado e o facão, além daqueles que usavam o arco e flecha. Os relatos do capitão do exército nos contam que, para se fazerem temíveis a seus inimigos, os guerreiros eyiguayegui vestiam "uma camisa de couro de onça” que lhes cobria até os joelhos, "a qual julga[va $] \mathrm{m}$ impenetrável a todas as armas ofensivas, mesmo ás balas”28. Além disso, segundo Sánchez-Labrador ([17701776], v. I: 308), uma das características eyiguayegui que fazia aumentar o terror dos

\footnotetext{
${ }^{26}$ Sánchez-Labrador ([1770-1776], v. II:4) descreve o berrante como uma "corneta" feita do "cuerno de vaca" e cujo "ronco $[\ldots .$.$] aturde y amedronta".$

${ }_{27}$ Ver Figura 8, aquarela de Debret denominada "Carga de cavalaria guaicurú".

${ }^{28}$ Rodrigues do Prado (1795:40).
} 
europeus e outros povos inimigos de encontrá-los era “[ [...] la deformidad que se nota $[\mathrm{va}]$ en los colores de sus cuerpos. Se embija[va]n o pinta[va]n de negro de pies a cabeza para hacerse espantables a sus enemigos". E Mônica Pechincha também descreve esse costume dos guerreiros. No momento em que narra o primeiro ataque dos Kadiwéu aos paraguaios na Guerra do Paraguai, uma senhora kadiwéu conta à antropóloga:

No outro dia eles foram. É por isso que até hoje eles usam esse costume de invadir algum civilizado. Aí eles começaram a se pintar com carvão para não serem reconhecidos depois. É por isso que eles até agora usam esse costume porque foi o primeiro guerreiro que usou. Os Kadiwéu usam aquela tinta na guerra. Eles têm medo de serem conhecidos depois de algum tempo. Os nossos senhores antigos foram até a outra margem do rio. Kadiwéu já estava pintado de preto. Os paraguaios queriam ficar com todo esse campo. Depois que os Kadiwéu começaram a viagem, alguns foram de canoa, ou no próprio navio. Quando atravessaram, já era de madrugada e os paraguaios estavam naquela festa. Os Kadiwéu disseram: 'vamos deixá-los na festa'. Eles dançavam e bebiam e poucas horas depois todos estavam embriagados e dormindo ao ar livre. E os Kadiwéu ficavam só olhando. Quando os paraguaios ficavam bêbados eles começavam a cantar e a gritar. Eles estavam de festa. E até eles tocavam acordeão e têm até hoje uma música que eles tocavam que eles não esquecem porque era a música que tocava quando eles foram invadidos pelos Kadiwéu. Quando foi naquela madrugada mesmo, os Kadiwéu começaram a guerra contra o Paraguai (Pechincha 1994: 149-50, grifos meus).

Além de versar sobre a pintura negra dos guerreiros, que será discutida adiante, o relato acima traz também reflexões acerca de uma estratégia largamente utilizada pelos guerreiros: a de aproveitar-se da festa alheia para pegar os inimigos de surpresa e desprevenidos. De maneira parecida, muitas vezes as visitas realizadas aos fortes ou a outras habitações indígenas eram também parte de uma tática de guerra. Schmidel ([1602]:79), por exemplo, conta de uma visita dos capitães eyiguayegui a seu acampamento e dos presentes levados por eles aos espanhóis: "regalaron a nuestro capitán cuatro coronas de plata $[\ldots]$ y seis planchas de plata $[\ldots]$. Tambiém regalaron a nuestro capitán tres hermosas mujeres jóvenes". Ludibriados pela generosidade dos índios, os espanhóis não perceberam que estavam sendo, na realidade, amansados: um pouco antes do nascer do sol, as mulheres que lhes serviram de presente fugiram e ajudaram os guerreiros a atacar o acampamento dos europeus.

O "oferecimento" de mulheres durante as visitas, descrito várias vezes na documentação colonial, parecia ser uma tática usual no contexto chaquenho ${ }^{29}$. Almeida

29 Cabeza de Vaca ([1555]:161) conta que, certa vez, os Agaces (ou Payaguá) firmaram um acordo de paz com os espanhóis e "deram” a eles suas mulheres. Quando os soldados espanhóis saíram em uma expedição punitiva aos índios Guaicurú, perceberam só depois que “[a]s mulheres que [os Agaces] 
Serra (1845:369) afirmava ser uma prática daqueles índios oferecer suas mulheres, "que se mostravam fáceis e meigas" e, quando os inimigos estavam desavisados, as mulheres alertavam seus companheiros e o ataque se efetivava. De acordo com Almeida Serra, se as "presas" não baixavam a guarda, as visitas continuavam por tempo indeterminado, até que os Eyiguayegui encontrassem o momento oportuno para o assalto.

Rodrigues do Prado (1795:48) nos conta que, em novembro de 1777, os índios Eyiguayegui visitaram o Forte Coimbra oferecendo a paz e, em janeiro do ano seguinte, eles voltaram "trazendo em sua companhia algumas mulheres, além de carneiros, perús, pelles de veado e outras bagatelas mais”. Começaram os Indios então a chegarem-se mais para os Portuguezes, e a convidarem alguns a descansar no regaço das mulheres, o que acceitaram [ $\ldots .$.$] ” e, enquanto isso, trocava-se as carnes de caça e os$ animais por armas. Quando estavam indo embora, um dos índios deu “[ [...] um assobio, com o qual todos se entendem tão claramente como nós falando: com este signal, cada gentio com o porrete foi matando aquelle que lhe cahiu em sorte; alguns Portuguezes morreram mesmo no regaço das Indias; e estas e os maridos os degolavam”. Nessa ocasião, os Eyiguayegui mataram 54 portugueses, o que deixou o Presídio de Nova Coimbra em alerta por muito tempo ${ }^{30}$.

Além de degolar seus inimigos, o(a)s guerreiro(a)s eyiguayegui também tinham o costume de cortar as cabeças de seus opositores, carregando-as depois "seguras pelos cabelos, exibindo-as como um troféu de guerra" ${ }^{31}$.

Estas, arrastradas por los suelos, sirven de incentivo al furor de las viejas y de juguete a las flechas de los muchachos. Aquellas, medio desnudas, [...] salen y dan vueltas por todo el toldo, cantando gozos y endechas. A falta de la cabeza, es objeto de toda la fiesta la cabellera de alguno muerto (Sánchez-Labrador [1770-1776], v. I: 311).

O objetivo das expedições guerreiras era o de trazer para a tolderia os despojos da guerra: as cabeças e cabeleiras, que eram centrais nas danças das velhas e nos jogos das crianças, e o(a)s cativo(a)s, considerado(a)s pelos cronistas como a meta primordial das incursões eyiguayegui. Segundo Sánchez-Labrador ([1770-1776], v. I: 311), a causa principal da guerra para aqueles índios não era a dilatação de seus domínios e

haviam dado como reféns [...] haviam fugido e lhes avisado que a cidade havia ficado com pouca gente em virtude da ida do governador para combater os guaicurus. Roubaram os armazéns dos espanhóis onde tinham seus mantimentos e levaram mais de trinta mulheres guaranis”.

${ }^{30}$ Guido Boggiani ([1895]:186) passou por uma situação muito parecida com essas emboscadas durante sua estadia na aldeia de Nalique: certa vez, um velho Chamacoco ofereceu-lhe, em troca de tecidos e presentes, uma jovem "escrava” que o ajudaria nos "afazeres domésticos", oferta aceita pelo viajante. Depois de menos de uma semana, porém, a jovem se aproveitou da ausência de Boggiani, que tinha saído em uma expedição de caça, e voltou para a casa do Chamacoco, levando com ela diversos pertences do italiano. Ver Figura 5, o retrato daquela que Boggiani chamou (ironicamente, ao que parece) de "minha mulher".

${ }^{31}$ Cabeza de Vaca ([1555]:158-9). 
expansão de seus territórios, e sim seu interesse pelas presas. Os Eyiguayegui manifestavam, de acordo com o missionário, “[ $[\ldots]$ una indecible ansia de tener cautivos y chicos de cualquiera otra nación, aun de la española”, os quais levavam e criavam "según sus barbaros ritos y modales". Tanto que, de acordo com o missionário ${ }^{32}$, mesmo depois de iniciados, os jovens não eram verdadeiramente reconhecidos como guerreiros antes que provassem sua coragem e trouxessem da guerra "alguna cabeza ó cabellera”, sendo "escala y aún mérito [...] haber muerto lo menos tres enemigos", não sendo considerados soldados "si no son homicidas" ${ }^{3}$. Aos que atingiam essas exigências, os Eyiguayegui chamavam “[ ...] niodagaguadi, instrumentos por medio de los cuales comemos. Porque con los despojos de los enemigos y la caza mantienen su reputación y familia" ${ }^{44}$. O captor que mais tinha cativo(a)s, assim, "goza[va] una fama indeleble y autoridad grande en su toldo", e seu valor se tornava inquestionável.

Antes de seguir a reflexão acerca da guerra, é necessário fazer alguns apontamentos sobre os múltiplos elementos trazidos pelas narrativas coloniais acerca das expedições. Como demonstrado, a preparação do corpo dos "soldados" tinha início no nascimento das crianças, continuava nas festas de iniciação e menstruação e se estendia até as expedições guerreiras propriamente ditas, onde a preparação do corpo era alvo de atenção: a descrição acima traz dados sobre a camisa de couro de onça e o preto que cobria os corpos dos guerreiros. O "objetivo central" dessas expedições, ou seja, o rapto de cativo(a)s e de cabeças, deve ser também discutido, por parecer ser este o motor da nobreza e mesmo do sistema de saberes eyiguayegui: por conferir prestígio a quem mais captura, a socialidade eyiguayegui parece se fundamentar exatamente na busca por esse(a)s cativo(a)s e sua posterior criação. Por fim, é incontornável refletir também acerca dos dados trazidos pelas fontes que problematizam aquela divisão entre "senhores da guerra" e "senhoras da arte": tanto as mulheres são descritas nas expedições guerreiras ocupando posições centrais quanto os homens aparecem, em grande parte dos relatos, cantando, tocando flautas, tambores ou berrantes (o que, penso eu, pode ser considerado arte ${ }^{35}$ ).

\footnotetext{
32 Sánchez-Labrador ([1770-1776], v. I:315).

33 Aguirre (1973:479).

${ }^{34}$ O missionário descreve também a "classe" dos meninos que se chamavam nachigue tenagadí, que tocavam qualquer instrumento nas ocasiões acima enumeradas (Sánchez-Labrador 1910 v.II:9). Não está claro, porém, se essa era uma "camada" separada da dos guerreiros ou se formavam um grupo especializado.

${ }^{35}$ Não faz parte do escopo dessa dissertação discutir conceitos de arte e/ou definir, de antemão, algumas práticas eyiguayegui/kadiwéu como "artísticas". Ao afirmar que os cantos e as melodias masculinos
} 


\subsubsection{Corpos guerreiros}

Ainda que as fontes considerassem as expedições guerreiras eyiguayegui desordenadas, seus dados mostram esquemas e táticas muito bem delineadas, em que cada passo parecia ser premeditado. Também a preparação dos corpos guerreiros não passava despercebida na preparação para as expedições.

A camisa de couro de onça, de acordo com Sánchez-Labrador, fazia com que os "soldados" tivessem seus corpos impermeabilizados. Ainda que não haja dados que corroborem esta interpretação do missionário, é significativo o fato de que, além do couro que servia de uniforme de guerra, também os dentes das onças eram utilizados nas perfurações anteriormente descritas. Talvez os guerreiros não acreditassem, como afirmava o jesuíta, que a camisa os tornava à prova de balas, mas há vários motivos para crer que, para além da proteção que a pele pudesse ou não oferecer ao guerreiro, tratava-se de vestir a pele da onça para "virar onça". Como afirma Viveiros de Castro (2002: 393), em muitos contextos ameríndios, "vestir uma roupa-máscara é menos ocultar uma essência humana sob uma aparência animal que ativar os poderes de um corpo outro". Ir para a guerra depois de ter a pele perfurada pelo dente e vestir a pele do inimigo mais temido por todos os seres do Chaco seria, nesse sentido, uma maneira de os guerreiros adquirirem suas qualidades na guerra. Ao utilizar a pele da onça nas expedições, portanto, os "soldados eyiguayegui" estariam menos se disfarçando ou se protegendo do que se servindo de um "equipamento distintivo dotado das afecções e capacidades" 36 que a definem.

A pintura negra, por sua vez, parece se explicar pelo efeito protetor do jenipapo. Note-se que, de maneira parecida com os guerreiros, também os recém-nascidos e as crianças eram pintados com tinta de jenipapo dos pés à cabeça ${ }^{37}$. Em ambos os casos a pintura parece se explicar pela proteção oferecida pelo jenipapo contra espíritos (no caso das crianças) ou inimigos (no caso dos guerreiros). De maneira parecida, os recémnascidos kaxinawá, segundo McCallum (1998), também são pintados de negro para “ajudar no seu crescimento e evitar doenças". Segundo a autora, “aplicações ocasionais de jenipapo parecem fixar a forma fabricada pelo trabalho intenso dos parentes tanto

eyiguayegui podem ser considerados arte, pretendo apenas questionar um discurso que entende somente atribuições (teoricamente) ligadas ao feminino como artísticas.

36 Viveiros de Castro (2002: 394).

37 De acordo com Sánchez-Labrador ([1770-1776], v. I: 315) e Lévi-Strauss (1996: 170), as crianças só eram liberadas dessa pintura quando chegavam ao momento da festa de perfuração ou da menstruação, entre os 10 e os 14 anos. 
durante quanto após a gravidez; ao mesmo tempo, o jenipapo torna o bebê invisível aos espíritos" ${ }^{38}$. Talvez seja este último fato o mais importante. Pois o mesmo objetivo tornar o corpo invisível aos inimigos - é declarado por vários povos indígenas das Américas para explicar as mesmas práticas de cobrir os bebês e guerreiros de negro. Nesse sentido, ainda que, segundo Sánchez-Labrador, a pintura preta tornasse os guerreiros eyiguayegui temíveis aos europeus, a intenção daqueles índios parecia ser não a de impor-se ao inimigo, aparecendo como "temíveis", mas, ao contrário, a de "desaparecer", "sumir". A afirmação da interlocutora de Pechincha de que, por meio da pintura negra, visava-se impedir que os guerreiros eyiguayegui fossem reconhecidos (ou mesmo vistos) confirma que, se a cobertura negra protege, é porque os inimigos (de qualquer tipo) não vêem os corpos assim pintados. Portanto, mais do que o fazer-se temível, o fazer-se invisivel parecia ser o modo dos guerreiros eyiguayegui, assim como a "esquiva" é o modo dos xondaro (guerreiros) guarani ${ }^{39}$.

Se o preto do jenipapo "fecha o corpo", contendo-o e protegendo-o, o vermelho do urucum, ao contrário, abre-o, e por isso mesmo não podia ser usado nas expedições. Em uma subseção do capítulo direcionado à guerra, denominada "Pintonse de negro, no de encarnado” (ou seja, de vermelho) Sánchez-Labrador ([1770-1776], v. I: 308) afirma que a pintura dos "soldados" era, como vimos, negra. A cor vermelha, que tanto usavam em seu cotidiano, "no se le usan en la guerra. Le tienen por infausto para sus victorias. Dicen que si van teñidos de Nibadena [urucum], fijamente su sangre correrá por tierra, y quedarán o muertos o saldrán heridos sin gloria”.

Como em tantos outros contextos ameríndios, as pinturas corporais preta e vermelha, jenipapo e urucum, são operadores respectivamente de fechamento e abertura, proteção e vulnerabilidade, ocultação e exibição ${ }^{40}$. Ambos modificam e constroem os corpos eyiguayegui em contextos específicos: dentro das tolderias usavase o vermelho, abrindo os corpos para a aquisição de potências "externas"; fora delas, em guerra, o preto, para a evitação dessas mesmas potências. Há vários indícios de que os bebês, também pintados de preto, estariam (ainda) "fora" das tolderias, recémchegados que são, com corpos ainda não (con)formados, tema a que voltarei abaixo.

\footnotetext{
${ }^{38}$ McCallum (2001: 21) apud Fausto (2002: 20).

39 Ver Santos (2016).

40 Entre os Kisêdje, por exemplo, o vermelho é associado ao calor e à belicosidade, enquanto o preto é a "cor associada com atributos anti-sociais e com feiticeiros" (Seeger 1980: 51). Também Lux Vidal (1999: 172 ) encontra entre os Kayapó-Xikrin um jogo de oposições entre o preto e o vermelho, onde o vermelho é utilizado, geralmente, em situações liminares e na periferia das aldeias, enquano o preto é usado em momentos de participação plena na vida da comunidade.
} 
Os cativos, por sua vez, permaneciam sendo "de fora", ainda que fossem gradualmente incorporados - de forma literal, pela transformação de seus corpos - às famílias eyiguayegui. Esse processo gradual de cativação daqueles que eram agarrados nas expedições guerreiras será o tema da próxima seção.

\subsection{Fome de crianças}

Os filhos, pensava ele, são modos de estender o corpo e aquilo a que se vai chamando alma. São como continuarmos por onde já não estamos $e$ estarmos, passarmos a estar verdadeiramente, porque ansiamos e sofremos mais pelos filhos que por nós próprios, assim como nos reconfortam mais as alegrias deles do que a satisfação que diretamente auferimos. Por isso temos gula pelos filhos, uma gula do tamanho dos absurdos, sempre começada, sempre incontrolável.

“O filho de mil homens", Valter Hugo Mãe.

\subsubsection{Criação e cativação}

O roubo, como afirmado, é considerado pelos Kadiwéu sua vocação, e o roubo de crianças parece ser o ideal máximo de concretização dessa "missão" que lhes foi confiada pelo carcará. As crianças (e, algumas vezes, mulheres e/ou homens já adultos), cativadas, como dito acima, eram tidas como medida do prestígio de seus capitães, o que fazia com que a guerra fosse descrita, muitas vezes, como uma corrida em direção à glória. Sánchez-Labrador, como vimos, afirmava que a motivação dos "soldados" era a oportunidade de provar seu valor. Clastres (2004: 270), por sua vez, defendia a ideia de que "o amor à guerra" era, entre os guerreiros chaquenhos, "uma paixão secundária, derivada de uma paixão primária: o desejo mais fundamental de prestígio”, sendo a guerra "o meio mais rápido e mais eficaz de realizar seu objetivo" ${ }^{41}$. As informações trazidas tanto pelas fontes quanto pelas etnografias atuais, porém, sugerem que a “paixão primária” eyiguayegui era o processo de cativação dos "prisioneiros" de guerra. Considero possível afirmar, portanto, que, de maneira parecida com aquela dos Tupinambá, toda “a vida social” eyiguayegui - incluindo a guerra e o prestígio concedido aos que agarravam mais pessoas em terras estrangeiras - era "posta a

${ }^{41}$ O desejo pela glória buscado pelos guerreiros chaquenhos, segundo Clastres (2004), seria contrabalanceado pelo desejo de indivisão das sociedades ditas primitivas. O prestígio concedido aos "soldados", assim como aquele concedido aos chefes, seria, portanto, "sem poder". 
serviço" da relação entre os captores e cativos ${ }^{42}$. Assim como os Nivacle (ou Chulupí) do Chaco central, estudados por Adriana Sterpin (1993), a hostilidade constante em que estavam submersos os Eyiguayegui e seus vizinhos parecia fazer parte da manutenção do sistema de cativação, que só continuava em andamento por meio da guerra e do roubo.

Como afirmado no capítulo anterior, quando chegavam às tolderias, os cativos de guerra eram designados iiôdiimiguit, "agarrados", e eram considerados potencialmente perigosos por serem estrangeiros. O tratamento à segunda geração de cativos (os nibotagi), porém, era bem diferente: ainda que a eles ficassem reservados, segundo Susnik, os trabalhos entendidos como "menores" pelas fontes, eram considerados parentes. Não é incomum encontrar relatos de casamentos entre capitães e nibotagi, como demonstro adiante. Aliás, segundo as fontes históricas, os cativos constituíam a maior parte da população das tolderias eyiguayegui. Segundo Almeida Serra (1803:211), esses estrangeiros agarrados nas expedições guerreiras eram a própria condição da sobrevivência daquela sociedade, que sem eles teria sido aniquilada há muito tempo. O comandante descreve a população presente nas tolderias da seguinte forma:

\begin{abstract}
Decompondo-se este aggregado total da famigerada nação Uaicurú, poucos d'elles ficarão que sejam de uma antiga origem; pois dos 2.600 Indios dependentes de Coimbrat ${ }^{43}[\ldots]$, tirados os 600 Guanás, que vivem como aldêados, e seprados d'elles, dos 2.000 que restam, 500 ainda são Guanás, e seus filhos entre os Uaicurús estabelecidos, ou como antigos e actuaes captiveiros no nome, ou por casamentos; montando com pouca diferença a 500 Xamicocos os d'esta nação, há cinco anos adquiridos. Finalmente das 1.000 almas que ainda restam, talvez não cheguem a 200 os que se possam chamar verdadeiros Uaicurús; sendo os 800 para completar a somma total um composto de Bororós, Chiquitos, Cayapós, Cayuabas, alguns Negros, Caborés, bastardos e seus filhos e netos, de todos estes diversos Indios misturados entre si pelos casamentos que tanto os Uaicurús como todas estas nações praticam uns com outros, logo que entram em cada uma das tribus que foram o todo dos Uaicurús.
\end{abstract}

Ao tentar demonstrar que a "famigerada nação Uaicurú" era constituída por poucos nobres provenientes "de uma antiga origem” e por muitos estrangeiros, dos quais os Eyiguayegui dependeriam para a sobrevivência de sua sociedade, Almeida Serra acaba por demonstrar uma distinção muito parecida com aquela entre os iiôdimiguit e os nibotagi: a diferenciação entre os "captiveiros" antigos e atuais. A

\footnotetext{
4.2 Sugiro que o par captor(a)/cativo(a) que fundamenta grande parte das relações eyiguayegui se assemelha, nesse sentido, ao par matador/cativo discutido por Carneiro da Cunha \& Viveiros de Castro (2009: 82).

${ }^{43} \mathrm{O}$ comandante se refere ao aldeamento localizado nas proximidades do Forte Coimbra, "nos campos contínguos às serras de Albuquerque”, no atual Mato Grosso do Sul (Almeida Serra 1803: 211).
} 
denominação de Almeida Serra parece sugerir que um cativo de guerra considerado estrangeiro podia ser incorporado ao longo do tempo.

Guido Boggiani ([1895]: 133) também parece seguir a mesma lógica. Segundo ele, ainda que os cativos fossem mais selvagens que seus captores, quando "tornados escravos, pouco a pouco [iam] adquirindo os bons hábitos dos seus senhores, embora lhes fi[cassem] sempre um grau abaixo". Além de apontar para uma concepção de escravidão como meio de civilização, que não poderá ser discutida aqui ${ }^{44}$, o trecho extraído dos diários do italiano (assim como a descrição de Almeida Serra) acaba por nos apontar um processo muito presente entre as populações ameríndias: aquele do assemelhamento corporal efetuado pela convivência e pela aquisição dos "bons hábitos" dos (potenciais) parentes, que parecia ocorrer com os cativos. E aqui se faz necessário abrir um parênteses para apresentar, ainda que resumidamente, uma discussão que tem atravessado grande parte das análises etnológicas atuais sobre os povos sulamericanos: aquela sobre a construção dos corpos por meio das relações cotidianas.

Em seu artigo seminal ${ }^{45}$, Anthony Seeger, Roberto da Matta e Eduardo Viveiros de Castro argumentavam que conceitos clássicos como corporação, descendência e filiação, então muito produtivos nos estudos sobre sociedades africanas, não poderiam ser "aplicados” às pesquisas sobre as populações ameríndias. Se em África o locus da oposição individual-coletivo parecia ser o do grupo corporado, estruturado por meio de um ancestral fundador, pelo controle da propriedade e regulação de direitos e deveres, na América do Sul essa oposição teria como locus privilegiado a construção do corpo, que não é entendido nos mesmos termos das noções ocidentais ${ }^{46}$. De acordo com os antropólogos, se em África a vida social é regulada por meio da descendência, nas terras baixas da América do Sul as relações sociais passam necessariamente pelo corpo e por sua constante construção: ao contrário de "grupos corporados" africanos, teríamos em nosso continente "grupos corporais" fundamentados em laços de identidade corporal construídos por meio das relações de substância entre os parentes ${ }^{47}$.

É importante notar que, ao contrário do que possa parecer, essa construção do corpo não remete a um processo de “inscrição cultural” em um corpo "dado” ou "natural": é por meio das intervenções sociais que os corpos ameríndios são

\footnotetext{
${ }^{44}$ A ideia fundamenta políticas coloniais europeias e atravessa, por exemplo, a legislação colonial portuguesa relativa aos índios (ver Perrone-Moisés 1992; 2000).

${ }_{45}$ A construção da pessoa nas sociedades indígenas brasileiras (1979).

46 Seeger, Da Matta e Viveiros de Castro (1979: 14).

47 Seeger (1980).
} 
efetivamente criados. Eles não são, portanto, "pensados sob o modo do fato, mas do feito". É por conta dessa concepção do corpo que observamos, em grande parte dos povos indígenas americanos - entre eles os Eyiguayegui -, "a ênfase nos métodos de fabricação contínua do corpo" 48 . Esse fazer e refazer dos corpos ameríndios, que tem lugar nas relações sociais e não em substratos que poderíamos considerar "biológicos", acaba por esfacelar a dualidade entre indivíduo e sociedade: o indivíduo, tal como o pensamos, não faz sentido nas terras baixas sul-americanas. Pois as pessoas são constituídas corporalmente por suas relações ou, como afirma Tola (2012a: 33), seus corpos são resultado da combinação de substâncias, fluidos e componentes que diríamos "exteriores" a eles sendo, portanto, múltiplos. Esse processo de composição dos corpos começaria, de acordo com a literatura americanista, na gestação.

As fontes históricas e mesmo as etnografias atuais trazem pouquíssimos dados sobre o processo de criação, no útero materno, do corpo dos bebês entre os Eyiguayegui ou Kadiwéu. O máximo de informação que temos é que as mães deviam se abster totalmente de atividade sexual desde o início da gestação até mais ou menos o quinto ano de vida da criança: segundo Rodrigues do Prado (1795: 31), os Eyiguayegui seguiam o costume de "não ter comunicação o marido com a mulher durante a prenhez e criação dos filhos". Afirmava-se que os maridos "não pod[ia $] \mathrm{m}$ encostar" nas suas esposas até pouco depois do fim da amamentação do bebê “ $[\ldots]$ porque diz $[$ ia $] \mathrm{m}$ que usando da sua mulher, ou morr[ia] o filho ou fica[va] o filho doente para sempre, não motivando damno algum os tratos que ella t[i] nha com outros homens"49.

Resguardos como esses, durante a gestação e pós-parto, são disseminados por toda a América indígena e são descritos tanto em documentos coloniais quanto em etnografias contemporâneas. Eles parecem indicar que as concepções acerca da construção corporal eyiguayegui corroboram a afirmação que tem sido repetida na produção americanista atual de que o parentesco indígena, assim como o corpo (e em conjunto com ele), não é dado ou definido previamente por considerações genéticas, mas sim construído por cuidados e comportamentos específicos (como o resguardo, no caso citado), concebido como um "processo de assemelhamento ativo dos indivíduos pela partilha de fluidos corporais, sexuais e alimentares" ${ }^{50}$, além dos cuidados mútuos, do respeito aos resguardos e mesmo do desejo de ser parente ${ }^{51}$.

\footnotetext{
48 As duas citações deste parágrafo são de Viveiros de Castro (2002: 390).

49 Almeida Serra (1850: 357).

50 Viveiros de Castro (2002: 390).

51 Vilaça (2002: 352).
} 
Um ótimo exemplo desse compartilhamento de substâncias é trazido por Florência Tola. Segundo a antropóloga, a gestação para os $Q^{\circ m^{52}}$ é resultado de um longo processo: "é preciso muito trabalho para gerar um filho" 53, dizem seus interlocutores. Pois a "corporização" da criança só acontece com o acúmulo do sêmen no útero materno, resultado de diversas relações sexuais entre o período de três a quatro meses. Mas esse acúmulo do sêmen e sua união com o sangue menstrual da mãe não é o suficiente: a mãe precisa ter em seu útero, antes de mais nada, o nqui’i do bebê, ou sua "imagem", que lhe é trazida por sonho ${ }^{54}$. O nqui’ $i$, é muitas vezes substituído nos estudos antropológicos por "alma”, mas essa tradução, segundo a autora, não parece ser a mais correta exatamente por evocar uma separação entre corpo e alma que parece não existir entre os Qom (e nem parecia existir entre os Eyiguayegui, como veremos). O nqui’i é, então, "corporizado", nas palavras da autora, a partir do sêmen e do sangue menstrual, que se juntam e criam o corpo do bebê em três ou quatro meses. Segundo uma das interlocutoras de Tola (2007: 507), “'somos todos feitos de sangue e de lmale' [esperma]. Por isto, a criança conhece o odor do pai e da mãe quando ela nasce”. E tanto o esperma quanto o leite materno se relacionam ao sangue, que

[...] é o principal elemento do corpo, uma vez que suas composições e circulação determinam a boa saúde e o crescimento de cada pessoa. $\mathrm{O}$ sangue da menstruação, o esperma e o leite são concebidos como suas transformações ou seus derivados. Esses fluidos passam de um corpo a outro através de seus orifícios e da pele, de modo que, com o tempo e o decorrer das relações, a constituição do sangue próprio de cada pessoa é diferente. Assim, entre aqueles que compartilham os fluidos corporais, desenvolve-se e circula o mesmo sangue, que concorre para a criação de um corpo comum e de uma memória dos pais.

É importante notar que, por mais que a noção de "substância" remeta à ideia de um substrato físico e material, fica claro pela fala da interlocutora de Tola e por sua análise que o sangue, o esperma e o leite materno a que elas se referem não são os mesmos que os "nossos": eles não se restringem a apenas um corpo, "circulando" entre diferentes pessoas; são capaz de criar e transmitir memórias entre membros de um mesmo grupo; possuem cheiros específicos, de acordo com cada pessoa, e, por fim, não são separados de uma ideia de "espírito"/“alma”/"consciência”"55. Ainda que Tola se refira ao esperma e ao leite materno como “derivados do sangue”, acredito ser possível

\footnotetext{
${ }^{52}$ Reconhecidos na literatura muitas vezes como Toba, o Qom são também falantes da língua Guaicurú e habitam, atualmente, o Chaco argentino.

53 Tola (2012a: 136).

${ }_{54}$ Tola (2012a: 136).

55 De maneira similar, em diversos contextos amazônicos o sangue opera como um vetor de relações, sendo visto como o lugar mesmo da memória e do pensamento, sem os quais os laços de parentesco não existiriam (Belaunde 2006: 2010).
} 
afirmar que, na maior parte das filosofias ameríndias, essas substâncias são pensadas como variações umas das outras, conectadas entre si pelo fato de carregarem "partes" de pessoas, fazendo-as circular.

O assemelhamento corporal resultante do compartilhamento dessas substâncias, por sua vez, só é possível porque os corpos "estão abertos à influência e incorporação de outros corpos e pessoas" ${ }^{56}$. Como diria Vilaça (2002: 352), no contexto amazônico (mas não só) não é a substância que define as relações sociais, como aconteceria na noção "ocidental”, e sim as relações sociais que definem as substâncias e o corpo. Nesse sentido, a fabricação social das relações é muito mais importante para o desenvolvimento de laços afetivos e corporais do que questões genéticas e por isso, segundo Vilaça (2002: 354), um "bebê no útero" e uma criança estrangeira passam por processos de aparentamento similares. Quando um bebê nasce, ele precisa ser inserido nessa rede de relações, além de necessitar aprender os modos de seus parentes ${ }^{57}$. Esse processo de aparentamento é muitas vezes descrito como um movimento de transformação corporal. Almeida Serra (1845: 359), por exemplo, conta dos Eyiguayegui que “[o] maior cuidado das mães é o estarem effectivamente estendendo, comprimindo e puxando os braços, pernas, e mais membros das crianças que por tenros, cedem e se moldam à estatura perfeita que se nota em todos estes índios”. Essas "massagens" realizadas pelas mães em seus filhos podem ser lidas como mais uma forma de construir corpos aparentados. Carlos Fausto (2002: 19) descreve operações bem parecidas entre os Parakanã, povo de língua tupi. De acordo com os interlocutores do antropólogo, "são essas operações que tornam os corpos" parakanã diferentes de corpos outros, que "não são jamais modelados".

O mesmo parecia acontecer com as crianças agarradas nas expedições: elas eram, aos poucos, incorporadas, aprendendo a comer, se vestir, falar e se comportar como eyiguayegui, tendo seus corpos efetivamente transformados. Era assim que um cativo "atual" se transformava em um cativo "antigo": pelo processo de assemelhamento corporal e comportamental com a família eyiguayegui de que passava a fazer parte. Talvez por isso os Kadiwéu denominem aqueles que as fontes qualificaram muitas vezes como "escravos" de "cativos" ou "criados": o que parece ser

${ }_{56}$ Oakdale (2008: 792, tradução minha).

57 Entre os Hauaroni da Venezuela apresentados por Rivall (1998) o recém-nascido é tratado como hóspede por seus pais, os anfitriões, e deve ser gradualmente incorporado à sua casa por meio de atos específicos, como a comensalidade. Já entre os Kayabi, interlocutores de Oakdale (2008: 798, tradução minha), os bebês só começam a ser reconhecidos como parentes no momento em que passam a comer um "mingau de comida pré-mastigada". Nesse ponto, os Kayabi dizem que eles estão começando ficar "maduros", ao invés de "verdes" como eles eram ao acabar de nascer. Nas palavras de uma mulher kayabi, é nesse ponto que os “bebês começam a se transformar em pessoas”". 
central na relação com os cativos de guerra é sua criação como eyiguayegui e/ou sua cativação gradual.

Outro paralelo entre crianças e cativos se expressa na centralidade e na importância do cuidado entre os Eyiguayegui e Kadiwéu. De acordo com Lecznieski (2005: 125), a preocupação com boa formação dos corpos das crianças é constante entre os Kadiwéu:

A preocupação pelo nascimento de uma outra criança quando o irmão/ã ainda é pequeno me foi demonstrada diversas vezes durante as conversas. Certa vez, por exemplo, uma senhora idosa indicou para que eu olhasse na direção de uma menina de uns três anos de idade que, debruçada nas pernas da mãe, olhava o irmãozinho que mamava, e exclamou, sacudindo a cabeça num misto de lamento e reprovação: 'Olha aquela pobrezinha, ali! Tão pequena ainda e já tem outra tomando seu lugar, seu leite. Por isso que antigamente a gente matava, matava mesmo, não deixava ficar sofrendo desleixo’.

A "competição" entre irmãos muito próximos em idade é um dos motivos comumente citados pelas mulheres kadiwéu para a prática do aborto. Como vimos, os resguardos pós-natais chegam a durar até cinco anos, o que parece indicar que o corpo da criança ainda não está suficientemente formado até então. Entre os vizinhos dos antigos Eyiguayegui, os Qom, acontece algo parecido. De acordo com Tola (2012a: 124), há entre esses índios uma doença denominada chonek, termo traduzido por um de seus interlocutores como "desnutrido". Os dados da antropóloga indicam que, enquanto estão amamentando, as mães não devem ficar grávidas novamente. Se elas desrespeitam essa restrição e dão continuidade a uma nova gestação, "el hijo lactante será destetado para evitar su debilitamiento a raíz de los ataques de su hermano en gestación, ataques que se expresarán mediante los fluidos corporales de la madre”. É interessante notar que, além do perigo do ataque de um irmão por outro, parece haver também um cuidado com a circulação das substâncias: considerando os relatos qom e kadiwéu em conjunto, parece ser possível afirmar que a mãe precisa ter controle sobre seus fluidos (como o leite) para que o corpo de seu filho possa ser bem formado e não fique "desnutrido". Boggiani ([1892]: 162) apresenta um dado eyiguayegui que parece ir na mesma direção. Segundo o italiano,

[…] o aleitamento de crianças só termina quando estas não querem mais saber das fontes maternas. Vi rapazinhos de mais de cinco ou seis anos mamar ainda desbragadamente e é coisa comum ver meninas de três ou quatro anos penduradas a peito das pacientes mães.

Se o aleitamento tardio era causa de espanto para os europeus, também a maneira como as crianças (nascidas nas tolderias ou não) eram tratadas era causa de 
admiração (e julgamento moral). Sánchez-Labrador ([1770-1776], v. I: p. 293) escreve em seu diário:

Hasta los doce años les muestran un amor extremado. Jamás les corrigen sus travesuras, ni les hablan de modo que las palabras les sirvan de freno. Castigarlos fuera un exceso que tocara los límites de la impiedad en sentir los Eyiguayeguis. Miran esta corrección en los españoles como de gente desamorada. Así crían a sus hijos, saltando y retozando como unos cabritillos.

A liberdade das crianças é assunto também entre os não-Kadiwéu que vivem atualmente na R.I. Kadiwéu, de acordo com Lecznieski (2005: 74). Segundo eles, "as crianças kadiwéu 'nunca são contrariadas', ‘sempre vencem', ‘fazem o que querem', seus pais têm sempre que 'se curvar às suas vontades". Muito similares são os comentários dos cronistas a respeito do tratamento dos cativos por seus "senhores". De acordo com Almeida Serra (1845:205), era de se espantar o "extremoso mimo e amor com que trata[va]m e cria[va]m algumas crianças que compraram e furtaram às nações vizinhas". O autor afirma ainda que os cativos comiam "no mesmo prato com seus senhores" e casavam regularmente "com os livres e em outras toldarias e tribos". Segundo Taunay (1931:21, grifos do autor), “o captiveiro faz parte da família, com ella come, é tratado como filho da casa; tem até regalias especiaes. Irá a senhora buscar agua á fonte a lavar a roupa que pertença ao escravo, mas nunca o obrigará a estes serviços!”. Os relatos de Francisco Rodrigues do Prado (1795:27-8) vão no mesmo sentido: de acordo com ele, a "parte" da sociedade eyiguayegui formada pelos cativos “a mais considerável”, aliás - era tratada pelos seus capitães "com muito amor". No mais, as mulheres eyiguayegui amamentavam as crianças cativas e o luto pela morte dos nibotagi não era diferente daquele devido aos parentes eyiguayegui. "Os cativos", por fim, não se envergonhavam "de sua condição, antes, d'ella se gloria[va $] \mathrm{m}$ ”. Sobre os casamentos entre cativos e as pessoas consideradas "livres" e a "adoção" das crianças raptadas, o militar escreve, ainda, que

[t]odos estes novos adquiridos, e chamados pelos Uaicurús seus cativeiros, ou sejam Xamicocos, Bororós, Guanás ou outra qualquer das por eles flageladas nações, logo que entram em cada tribu, são reputados como membros d'ella. Algumas crianças ficam adoptadas como filhas, outras vem a casar com seus senhores, e assim, dentro em poucos anos, fazem estes novos membros um mesmo todo, ainda que sempre com o nome de cativeiros (Almeida Serra 1845:206).

O tratamento dado aos cativos fazia com que os autores das fontes desconfiassem, muitas vezes, de seu próprio vocabulário e se questionassem acerca da linguagem utilizada em seus relatos, considerada muitas vezes limitada e inadequada ao contexto eyiguayegui. Rivasseau (1934:87), por exemplo, chega a afirmar que, se a 
categoria de "escravos existe, no fundo, o que significa não subsiste", uma vez que a relação entre senhores e cativos era muito mais suave do que a de escravidão. Almeida Serra (1850:371), por sua vez, questiona até mesmo a categoria de "cativos" que, "entre os Uaicurús, equivale mais á significação de adquiridos ou de libertos, do que do rigoroso sentido d'esta denominação”. Essa confusão dos autores, por sua vez, parece ter origem na percepção dos movimentos alternados de abertura e fechamento discutidos acima e que serão objeto de reflexão da próxima seção.

\subsubsection{Caduveização}

Aos índios chamacoco que haviam "sido escravizados [...] pelos Caduveo" e “[d]esde então haviam $[\mathrm{m}]$ sempre vivido com estes últimos como um deles" ${ }^{58}$, Guido Boggiani chamava de "caduveizados". Esse processo de "caduveização" aparece nas entrelinhas de muitos relatos, como os apresentados neste capítulo. Há, nesses dados, pelo menos três elementos a serem sublinhados.

Primeiro: a afirmação feita por Almeida Serra de que cativos e senhores comiam no mesmo prato. Vimos que o compartilhamento da comida e a comensalidade são uns dos principais fatores no processo de criação da convivialidade e do parentesco. $\mathrm{Na}$ formulação de Oakdale (2008: 803), a comida tem um potencial de transformação identitária, fazendo circular entre as fronteiras categorias como o "estrangeiro" e o “mesmo”. Segundo Fausto, (2002: 15), “[c] $]$ omer como alguém e com alguém é um forte vetor de identidade, assim como se abster por ou com alguém”. Por isso mesmo, para o espanto dos europeus, os cativos faziam "parte da família".

Segundo: o fato (registrado por Rodrigues do Prado) de que as mulheres eyiguayegui amamentavam as crianças cativadas na guerra, além de lhes darem o mesmo tratamento que a seus filhos "biológicos" (com o "amor extremado" e sem impedimentos ou repressões). Esse dado nos mostra, efetivamente, o quanto as crianças nascidas de pais eyiguayegui e as trazidas na guerra passavam pelo mesmo processo de incorporação, constituído por atos como o da amamentação.

Esse processo gradual de aparentamento dos cativos descrito nas fontes é expresso pela própria terminologia do parentesco kadiwéu apresentada por Darcy Ribeiro (1980b: 76). De acordo com o autor, ao ser agarrado,

1) [o] 'cativo' adulto designa[va] o seu captor como 'meu dono' (iadji-miguit) ou 'meu senhor' (iniô-tagod), ou ainda como 'meu avô' (ié-

\footnotetext{
${ }^{58}$ Boggiani ([1895]: 59).
} 
mé); se [era] apanhado ainda menino, como 'meu pai' (aá-tád), à mulher do captor como 'minha senhora' (in-niô-tágod) ou 'minha avó' (iá-mit) ou ainda 'minha madrasta' (ia-nin-hôdot);

2) O filho do cativo designa[va o captor do pai ou da mãe como 'meu avô' (ié-mé) e a seus filhos como 'meu pai' (iá-tád); e a ambos como 'meu senhor' (iniô-tagod), e [era] tratado pelo primeiro como 'meu neto' (i-uá-lúdi) e pelo segundo como 'meu filho' (iôn-nát) o como 'meu cativo' (iô-taguít);

3) O filho do cativo designa [va $]$ o neto do captor de seu pai como 'meu irmão' (in-niô-txuá) e receb[ia $]$ o mesmo tratamento.

Segundo o antropólogo, a relação entre cativos e nobres ia da assimetria (partindo de uma relação entre avô e neto) para a simetria (culminando em uma relação entre irmãos) nos espaço de três gerações. Note-se que, ao chegar às tolderias, os cativos eram logo inseridos nas relações de parentesco eyiguayegui, ganhando novos nomes e passando a se referir a seus captores por termos que expressavam proximidade. De acordo com os dados de Ribeiro, havia uma diferença entre cativos adultos e crianças. Enquanto os que tinham pouca idade podiam chamar seus captores de "pai"/"madrasta", os adultos os chamavam de "avô"/"avó”. Segundo a argumentação de Ribeiro, tais dados seriam a evidência de uma distinção fundamentada na maior ou menor possibilidade de familiarização dos "prisioneiros" de guerra de acordo com sua idade $^{59}$.

Seja como for, termos de parentesco (tanto quanto nomes) são também constituintes do "parentesco enquanto relação corporal" em muitos grupos ameríndios (Coelho de Souza 2004: 29, grifos da autora), e sua utilização faz (e pode desfazer) relações ${ }^{60}$. Quer chamassem seus captores de "pais" ou “avós”, o importante é que os cativos já chegavam às tolderias aparentados e, com o tempo de convivência, eram gradualmente incorporados.

As etnografias atuais também descrevem o processo de aparentamento entre os descendentes de cativos e os "senhores". Discutindo a afirmação dos cronistas de que o casamento entre criados e nobres era proibido ${ }^{61}$, Lecznieski (2005: 204) escreve que, entre os Kadiwéu, parece mesmo acontecer o contrário:

\footnotetext{
${ }^{59}$ O que não seria uma particularidade kadiwéu: “é de pequenino que se torce o pepino”, diz-se entre nós. 60 Um exemplo trazido por Coelho de Souza (2004: 26): Entre os Krinkati, onde a interdição do casamento se expressa por termos de parentesco e as "relações indeterminadas", pelo uso de nomes pessoais, a passagem de um domínio de terminologia para outra, marcada pelo momento em que se começa a chamar uma prima pelo nome pessoal, é suficiente para iniciar um processo de distanciamento que acaba por transformá-la em uma possível esposa (o que não aconteceria se os termos de parentesco continuassem a ser usados).

${ }^{61}$ De acordo com Rodrigues do Prado (1795:28), a separação entre as duas partes era tão radical que chegava ao "ponto de que o filho despreza[va] a mãi que casou com escravo". Segundo SánchezLabrador ([1770-1776], v. I:311-315), o casamento com esses "escravos" era extremamente mal visto, pois os capitães temiam "manchar su nobleza com la baja condición de sus criados". "Por esto", afirma o
} 
a restrição do casamento com cativos não é apontada como forma de manter a hierarquia social estabelecida. Segundo os Kadiwéu, os senhores não podem casar com seus cativos por estes serem considerados seus parentes, mais parentes que outros parentes de sangue que vivem longe e não são vistos com frequência.

Diante do que tem demonstrado a etnologia americanista quanto à sobreposição de distância física (morar perto/longe) e distância relacional, não surpreende tanto que os cativos sejam considerados "mais parentes que outros parentes de sangue", mesmo porque a noção de "parente de sangue" é incompatível com tudo o que tem sido percebido entre os ameríndios. Viver longe é aqui o que importa, já que a distância tem, entre os índios, um efeito desaparentador, tanto quanto a convivência um efeito aparentador. Note-se, no entanto, que se os cativos vivem com seus "senhores" e a eles vão se assemelhando, nibotagi e niniotagi permanecem diferenciados uns dos outros. Este é o quarto elemento trazido pelas fontes a ser sublinhado: o fato de que, mesmo os cativos sendo adotados ou se casando com os Eyiguayegui, formando "parte de um mesmo todo", nas palavras de Almeida Serra, eles continuem sempre "com o nome de cativeiros".

Essa aparente contradição acontece porque esse "nós" eyiguayegui não é uma categoria fixa, como demonstrado no primeiro capítulo. Assim como em grande parte das Américas, "kadiwéu" (ou eyiwayegi) parece não significar a mesma coisa (ou não inclui as mesmas pessoas) em qualquer contexto. Um exemplo disso é o caso do “vereador kadiwéu”, descendente de cativos, trazido por Lecznieski (2005: 114-5):

Embora seja visto, apresentado e respeitado como autêntico representante político kadiwéu no mundo externo, internamente, tem sua identidade de terena sempre remarcada e lembrada. Embora tenha sido apresentado à Mônica Pechincha como um kadiwéu puro sendo inclusive um dos informantes que mais detalhes ofereceram sobre o 'sistema do índio' -, as histórias que ouvi enfatizavam, ao contrário, o fato de não ser, efetivamente, um kadiwéu.

Se na relação com os ecalai (os não-índios em língua kadiwéu) não havia dúvidas de que o vereador era kadiwéu, dentro da aldeia em que ele morava ocorriam discussões sobre sua identidade. Segundo um interlocutor de Lecznieski, a maior acusação contra o vereador era o fato de que ele não sabia falar "o idioma”, o que fazia com que o vereador precisasse a todo o momento provar sua fluência, mostrando que era, de fato, um kadiweú.

Como vimos no último capítulo, falar a língua, bem como saber o "sistema do índio", conhecer as histórias de fazer nomes e as histórias dos antigos é o que define a

jesuíta, "capitán Guaycurú por lo común se casa con capitana, mirando a los que no son de tal estirpe como gente plebeya, nascida para el vasallaje” (Sánchez-Labrador 1770:29 v. II). 
nobreza e, portanto, os "verdadeiros kadiwéu". As acusações por vezes dirigidas ao vereador parecem se incluir nessa lógica. Em relação aos ecalai, o vereador é kadiwéu: veste-se como eles, come como eles, vive com eles. Mas em relação às famílias nobres, detentoras dos saberes do "sistema do índio" ele ainda precisa se afirmar, como que para confirmar seu pertencimento. Entre "Kadiwéus", apenas um grupo tem o direito de assim chamar a si mesmo, ao passo que em momentos de relação com não-kadiwéu, são também assim reconhecidos os não-nobres e mesmo os descendentes de cativos. Nesses contextos (muitas vezes chamados interétnicos), onde a oposição relevante é entre kadiwéu e "brancos", um terena criado pelos Kadiwéu é obviamente um deles; ainda mais um que constantemente se esforça por tornar-se um "bom kadiwéu".

A (aparentemente) fácil conexão efetuada pelas fontes históricas (e mesmo por antropólogos ${ }^{62}$ ) entre "estrangeiro" e nibotagi (ou "escravo") parece ser fruto de uma desconsideração dos contextos, à diferença dos próprios índios. Nesses escritos, a oposição eyiguayegui/não-eyiguayegui acaba por se desdobrar naquela entre niniotagi e nibotagi e, no mais das vezes, não fica claro se os documentos estão opondo os senhores a seus cativos ou pessoas eyiguayegui (não necessariamente nobres) a pessoas guaná ou chamacoco, por exemplo.

Uma parte da literatura atual tende a separar uma coisa da outra, mas ainda as expressa em termos de oposição ${ }^{63}$. Segundo Lecznieski (2005: 137), por exemplo, a dinâmica do parentesco kadiwéu articularia dois níveis. "Num, processa-se uma diferença em termos de identidade étnica, distinguindo-se os Kadiwéu dos outros estrangeiros ou não-kadiwéu. Num segundo nível, processa-se uma diferença em termos da nobreza dos Kadiwéu, através da distinção entre nobres e não-nobres”. A autora segue seu argumento afirmando que esses dois níveis se articulam por meio de um "processo gradual de inclusão do outro". Primeiro, incorpora-se o estrangeiro à unidade étnica, para depois assimilá-lo à nobreza. No caso do "vereador kadiwéu", por exemplo, teríamos um processo de integração não totalmente efetuado: ele teria sido incorporado aos Kadiwéu, mas não à nobreza.

Basta, no entanto, levar a sério o que dizem de fato os interlocutores de Lecznieski: o vereador permanece terena - e nunca deixará de sê-lo - em relação aos “verdadeiros kadiwéu”, e é kadiwéu em relação aos ecalai. Não há contradição alguma

\footnotetext{
62 Refiro-me aqui a dois momentos da literatura sobre os Kadiwéu. Primeiro, à afirmação de SantosGranero (2009) de que o fato de os estrangeiros serem "menos-que-humanos" os faria ser vistos pelos Eyiguayegui como "escravos". Refiro-me também à relação direta entre "não-kadiwéu” e "cativo" efetuada por Pechincha (1994: 74).

${ }^{63}$ Ver Siqueira Jr. (1993: 79) e
} 
aí. Quando o contexto é ainda mais restrito, e inclui apenas nobres, outras diferenças aparecem: "algumas famílias nobres tendem a reivindicar, para si, uma nobreza mais legítima, apelando, em geral, para um conhecimento mais 'correto do idioma' e do ‘sistema do índio”" (Lecznieski 2005: 114).

Descrever as relações eyiguayegui como uma incorporação gradual pode ser produtivo quando a questão é a construção do parentesco por meio das relações cotidianas: as pessoas parecem mesmo passar por um processo gradativo de aparentamento e de humanização (para se tornarem "humanos" ao modo eyiguayegui, entenda-se). Por outro lado, porém, esse tipo de análise acaba por fixar os termos das relações, fazendo parecer que os cativos "caduveizados" passam de "fora" para "dentro" de um grupo fixo - "os Kadiwéu” -, o que não parece acontecer. Como vimos, ao mesmo tempo em que há uma abertura aos cativos, que são considerados parentes, podem assumir postos de chefia e mesmo representar os Kadiwéu na cidade, há também um fechamento que acaba por delinear, em alguns momentos, um grupo do qual algumas pessoas não fazem parte. A assimetria percebida pelos cronistas e antropólogos parece residir, em grande parte, nesse movimento entre a abertura e o fechamento ao Outro, atrelado a contextos específicos.

Esse processo duplo de expansão e contenção é vivido também no corpo. Em alguns momentos, espera-se que ele adquira características de seres de fora (como é o caso dos nobres) e, em outros, trata-se de evitar que estes seres atentem contra aqueles que se encontram efetivamente em campo de batalha (guerreiros) ou aqueles que se encontram em processos de incorporação (cativos e crianças). Nesse sentido, o fato (informado por Sánchez-Labrador e Santos-Granero) de que os cativos, assim como as crianças, podiam se pintar apenas com jenipapo, parece se explicar também pelo efeito protetor da pintura negra. Em ambos os casos, a pintura com jenipapo evitaria não só ataques, como também transformações indesejadas em seres que o grupo se esforça em incorporar a si.

No mais, vimos que a suposta sobreposição entre Eyiguayegui /nãoEyiguayegui e nibotagi/niniotagi não é total: nem todos os estrangeiros são "escravos" e se ocupam das atividades consideradas "mais árduas" e nem todos os Kadiwéu são nobres (a parte dos "comuns", que desaparece nas etnografias atuais, parecia ser formada pelos Eyiguayegui não-nobres, como afirmado). Grande parte dos desentendimentos originados nas fontes coloniais parece ter a ver com uma identificação exagerada entre esses termos, que faz com que os estrangeiros sejam vistos como essencialmente escravos e os Eyiguayegui sejam vistos como essencialmente 
nobres, ou guerreiros. Digo "exagerada" porque essa conexão parecia realmente ocorrer: o cativo de guerra era inicialmente incumbido de tarefas consideradas "domésticas", ao passo que um niniotagi era geralmente direcionado às atividades da guerra e da arte. Mas essas posições podiam se rearranjar, dependendo da construção do corpo das pessoas e das aptidões que elas desenvolvessem e/ou demonstrassem. Antes de seguir descrevendo esse "rearranjo", porém, é necessário tratar da instabilidade dos corpos eyiguayegui, que lhes permitia transitar entre essas funções.

\subsection{3 'Virar' outro}

No anno de 1800 houve em Coimbra umas febres agudas e nervosas, que puzeram em perigo de vida a alguns portuguezes de sua guarnição: A mesma moléstia atacou vigorosamente a preta Martha, filha da interprete Victoria, pelo que nosso cirugião lhe pôz cáusticos; os quaes principando na madrugada seguinte a fazerem o seu effeito, mas dolorosamente, estas dores escandalisaram os Uaicurús, que mandando chamar a Victoria lhe estranharam a fé que dava aos portuguezes, que queriam matar sua filha com aquelle violento remedio, e lhe arrancaram os causticos, e foi logo convidado um unigene [xamã eyiguayegui] para a cura; no espaço d'esta bulha, morreu no visinho rancho uma velha que logo lamentaram, e amortalhada a conduziram segundo o seu costume para o cemitério, n'este intervallo, olhando para a Martha a viram em lethargo; pelo que houve grande algazarra, e assentaram todos que a morta velha lhe tinha roubado e levava a alma; para embaraçar este roubo e fuga montaram a cavalo immediatamente bastantes Uaicurús, com lanças e porretes, e foram fazer, com grande gritaria, uma violenta e encarniçada escaramuça na estrada, e á vista d'este presídio; apezar d'esta cavalhada a alma sempre passou; pelo que um padre que já estava nu, mascarado de preto, vermelho e branco, e ornado de penas, tudo em hórrida figura, se lançou a correr n’uma violenta carreira para reconduzir a roubada alma de Martha, que foi achar d'aqui a quatro léguas embaraçada na passagem de uma bahia, gastando n'esta diligencia desde as nove horas da manhã até as cinco da tarde, em que voltou com a mesma apressadíssima carreira, trazendo no seu penacho a obsecada alma; elle fixo sobre os membros quando este unigene vinha chegando ao rancho da enferma, lhe atiravam as velhas com quantos tições de fogo acharam, para afugentar o Nianigugigo [Almeida Serra identifica Nianigugipo com o "diabo"]; chegando em fim o afadigado padre ao pé da doente se lançou por terra com o ventre para cima com mil medonhos gestos, urrando suffocadamente em quanto algumas velhas, umas sucedendo ás outras sobre a barriga lhe iam calcando, e elle bebeu duas grandes porções de água, o que tudo junto lhe produziu um copioso suor, até que de repente como um furioso possesso, muda o penacho das suas partes, para as da enferma; que immediatamente bafeja e vai repetindo entre urror os mesmos 
halitos, sobre a boca, ventas, ouvidos e olhos, e assim fez reentrar no corpo da enferma a fugitiva alma (Almeida Serra 1850: 365-6).

O roubo da alma de Martha é um dos únicos relatos presentes nas fontes sobre as doenças e o constante risco de transformação indesejada dos corpos eyiguayegui. Sobre este tema, temos ainda algumas narrativas sobre a morte e o luto e, como demonstro a seguir, muitas delas se referem ao medo sempre presente entre os Eyiguayegui de "virar bicho".

Como muitos outros relatos acerca das populações ameríndias, a descrição de Almeida Serra desfaz a dicotomia entre alma e corpo que fundamenta muitas das concepções ocidentais: de acordo com a narrativa do autor, o corpo de Martha é atingido quando sua "alma” é roubada pela falecida senhora, entrando em estado de letargia. No mais, mesmo a dicotomia entre material e imaterial, que acaba colocando a alma no lado do imaterial, não faz sentido quando temos a informação de que a alma de Martha foi "roubada", ou mesmo de que ela se "embaraçou" na passagem de uma baía, sendo levada de volta pelo unigene e reinserida no corpo da enferma. De saída, talvez possamos afirmar que nem o corpo de Martha nem o de nenhum eyiguayegui possa ser descrito como um "invólucro" impermeável a seu exterior e, como demonstrado, tanto a literatura sobre os Eyiguayegui quanto sobre outras populações ameríndias nos trazem pistas que confirmam essa hipótese.

Corroborando a narrativa de Almeida Serra, Darcy Ribeiro afirma que a doença é vista pelos Kadiwéu como resultado de feitiçaria ou do ataque de algum animal ou espírito de pessoas mortas. Nesses casos, diz-se que houve a "intrusão de bichos" no corpo do enfermo ou que a alma fugiu do corpo (Ribeiro 1980a: 217), o que parece ter ocorrido no caso de Martha. É interessante notar que nos três casos a doença é resultado do ataque de alguém: do feiticeiro (que manda seus "bichos" auxiliares "entrarem no corpo da pessoa"64), dos espíritos dos mortos (que sentem saudades dos seus parentes e tentam levá-los para a tolderia dos mortos, de que falarei adiante) ou dos animais. Essa concepção de doença, por sua vez, parece prevalecer entre os povos ameríndios. Entre os Wari, por exemplo, muitas doenças

são tidas como resultado do ataque de um animal que retém consigo a 'alma' da pessoa. Se seu corpo definha diante dos parentes, aos olhos do xamã que tenta curá-lo, ele está se transformando e adquirindo as características do animal agressor, i.e., está ganhando um novo corpo e novos hábitos, capacidades e afetos, da mesma forma que uma pessoa capturada na guerra deve ser familiarizada por seus raptores (Fausto 2002: 13).

\footnotetext{
${ }^{64}$ Ribeiro (1980a: 201).
} 
A doença entre os Eyiguayegui e os Kadiwéu, assim como entre outras populações ameríndias, nesse sentido, equivale a um perigoso processo de metamorfose: adoecer é estar se transformando em Outro. Martha, por exemplo, parecia estar se amigando da anciã morta e deixando-se levar para a aldeia dos mortos. $\mathrm{Na}$ visão dos Eyiguayegui vivos, Martha estava se esvaindo, morrendo.

Segundo os interlocutores de Jaime Siqueira Jr. (1993: 106-7), a morte acontece quando o ataque predador é bem sucedido e a pessoa doente sucumbe ao seu chamado. Logo depois do falecimento declarado pelo unigene, os Eyiguayegui pintavam com urucum os braços, o rosto e o peito do falecido ${ }^{65}$, vestindo-o com todos seus ornamentos. $\mathrm{Na}$ noite anterior ao sepultamento, os familiares (principalmente as mulheres anciãs) choravam e velavam o corpo, para na manhã seguinte levá-lo ao cemitério para enterrá-lo.

Nesse momento, de acordo com Siqueira Jr., a pessoa morta se reencontra com seus parentes falecidos na tolderia dos mortos, localizada no cemitério. Os Eyiguayegui tinham o costume de construir, em cima das sepulturas, toldos muito parecidos com aqueles em que moravam os vivos e que eram ordenados de maneira também similar. Tanto os "senhores" e "senhoras" quanto os cativos e cativas eram enterrados nos toldos de suas famílias e acabavam por reencontrar parentes que não viam havia muito tempo. As tolderias dos mortos são, segundo Dona Durila (interlocutora de Jaime Siqueira Jr.) o oposto das tolderias (ou das atuais aldeias) dos vivos ${ }^{66}$. Ninguém envelhece e ninguém tem malícia alguma. Lá, todos pensam que estão vivos e os seus parentes é que morreram. Segundo a história que narra as visitas de um homem kadiwéu à tolderias dos mortos ${ }^{67}$, “[q]uando morre uma família inteira, ficam todos juntos outra vez, nem sabem que morreram; quando morre um só ele fica chorando sozinho, pensa que os outros é que morreram”. Percebendo-se como pessoas vivas, e pensando nos vivos como parentes falecidos, os espíritos daqueles que morreram são extremamente perigosos. A história apresentada no anexo II mostra como, aos poucos, o homem que vai convivendo com os mortos, chegando até mesmo a se casar entre eles, se distancia gradualmente da comunidade dos vivos, acabando por morrer.

\footnotetext{
65 Esse dado confirmaria a relação entre vermelho e abertura se pensarmos que aqui o urucum promoveria a abertura do corpo do falecido para melhor propiciar sua transformação em Outro/Morto. Impede, no entanto, a associação entre vermelho e vitalidade, tantas vezes feita no contexto ameríndio. ${ }_{66}^{6}$ Como entre os Krahô, cf. Carneiro da Cunha 1978. Outros muitos paralelos poderiam ser assinalados nos parágrafos seguintes, que certamente não escaparão ao leitor. ${ }^{67}$ Anexo II.
} 
Todas as ligações entre o morto e seus parentes, portanto, devem ser $\operatorname{cortadas}^{68}$. Antigamente, o toldo em que a pessoa falecida morava era queimado, para que, se ela voltasse, não o encontrasse mais. Sendo as casas hoje de alvenaria, a precaução tomada pelos Kadiwéu é a de trocar as portas e mesmo janelas de lugar ${ }^{69}$. Quando voltam para casa depois do enterro, os parentes do falecido têm seus cabelos cortados, tomam banho e recebem novos nomes e termos de endereçamento - troca-se “mãe não-viúva” por "mãe viúva”, por exemplo70.

A mudança dos nomes e da terminologia de parentesco operada no momento do luto é explicada por Dona Albertina:

Nós índios não recebemos um nome à toa, só quando morre alguém trocamos o nome, porque os parentes da gente mesmo mortos ainda tentam procurar os parentes. Por isso tem algumas pessoas que ficam encarnadas, porque não trocam de nome quando seus parentes morrem. Por isso devemos trocar o nome e a pessoa que morre fica perdida dos seus parentes, e o espírito não quer saber daquele novo nome, porque não conhece quem é (Siqueira Jr. 1993: 112-3).

Além de trocarem seus nomes, os parentes também deixam de pronunciar o nome daquele que partiu, o que poderia ser fatal. Os nomes precisam esperar pelo menos duas ou três gerações (quando o morto já foi relativamente esquecido) para voltarem a circular ${ }^{71}$.

Os enlutados passam uma semana com a mesma roupa, não usam adornos, não participam dos eventos festivos, não saem muito de casa. Por determinado período (atualmente uma semana) eles são apartados de todos os eventos sociais. É como se a ausência do morto lhes causasse uma falta corporal e o "grupo de substância" precisasse se rearranjar:

como me falou uma velha, a tristeza dos parentes do morto fazia com que não ligassem mais para nada, nem para comer, nem tomar banho, ficavam ali, sem falar, sem cabelo, sem roupa, sem nada; deixavam 'carne viva o corpo'. 'Deixar correr sangue do corpo' (através de escarificações) era uma forma usada para 'mandar embora' a dor provocada pela morte de um ente querido (Lecznieski 2005: 191).

\footnotetext{
68 As práticas de luto descritas abaixo parecem não ser atendidas quando uma criança recém-nascida morre. De acordo com Lecznieski (2005: 193), "as crianças podem ser enterradas em casa porque ainda não dão medo”. Por ainda não serem consideradas propriamente parentes, não se teme as crianças pequenas como geralmente acontece com os parentes mais velhos.

69 Siqueira Jr. (1993: 107).

7o Sobre a mudança de nomes, ver Siqueira Jr. (1993: 107); Lecznieski (2005: 177). Para uma lista de terminologias de parentesco Kadiwéu, ver Lecznieski (2005: 176-7).

71 Segundo Siqueira Jr. (1993: 116), “[a]s restrições em relação à utilização dos nomes de indivíduos falecidos recentemente, dos últimos nomes dos antepassados e a escassa margem de liberdade para a criação de novos nomes, fazem com que as tarefas referentes à nominação indígena [efetuadas pelas mulheres anciãs] sejam muito valorizadas internamente". Veremos adiante como esses conhecimentos das velhas são elementos do seu prestígio.
} 
As escarificações, nesse caso, parecem querer expulsar o sangue do morto que ainda corre nas veias de seus parentes. A semana de luto figura, portanto, como o momento de afastar - de forma extremamente sofrida - tudo o que podia ser do falecido ou que pode evocar lembranças dele: fotos, objetos e mesmo vídeos. Lecznieski (2005: 178) conta que os Kadiwéu não assistiam ao filme Brava Gente Brasileira ${ }^{72}$ porque um dos meninos que atuaram no longa havia morrido. "Afirmando que não seria bom ver 'o corpo dele', pois, afinal, já tinha morrido, argumentavam que tal atitude poderia causar males, instigando, por exemplo, o morto a querer buscar ou procurar os vivos, colocando, assim, em perigo, principalmente a vida dos parentes que ficaram”.

As restrições aos enlutados geralmente duram até o velório da cruz - quando velam a cruz que irão colocar na sepultura do morto, aproximadamente uma semana depois de seu falecimento. Nessa ocasião, os enlutados recebem roupas novas, sentam no couro e bebem, celebrando seu retorno à vida social com uma "solene borracheira"73.

Todas essas ações realizadas no luto têm como objetivo proteger os parentes do falecido. Trocar portas e janelas de lugar e mudar de nomes, nesse caso, parecem ter um efeito parecido com a pintura preta que reveste o corpo de bebês, guerreiros e cativos: também essas ações pretendem despistar o outro (no caso, o parente morto) e tornar as pessoas invisíveis aos olhos do potencial predador. Em todos esses casos, a metamorfose é contida, o que, na maior parte das vezes, não acontece com o unigene.

A descrição de Almeida Serra nos faz perceber que o papel do unigene na cura de Martha é central. Vimos que ele vai à busca da alma roubada, capturando-a com seu penacho e reinserindo-a no corpo da enferma. Muitas vezes comparados aos xamãs amazônicos, os unigene de fato parecem ter a mesma habilidade de atravessar os diferentes mundos, cruzando barreiras corporais e efetuando a comunicação entre os Eyiguayegui e outros seres (como os espíritos e os "bichos"): segundo Ribeiro (1980a: 197), as duas "faces da sociedade Mbayá (vivos e mortos)" se comunicam através do unigene. Assim como os xamãs, eles parecem ver "os seres não-humanos como estes se vêem (como humanos)", sendo "capazes de assumir o papel de interlocutores ativos no diálogo transespecífico"74. O unigene é, portanto, uma pessoa cujo corpo está pronto para a metamorfose em todos os momentos, sendo sua atribuição se comunicar com

\footnotetext{
${ }^{72}$ Lançado em 2000 e dirigido por Lucia Murat, o longa-metragem de ficção Brava gente brasileira retrata alguns dos encontros entre os oficias portugueses do Forte Coimbra com os Eyiguayegui no final do século XVIII. Os atores que atuaram no filme como os antigos eyiguayegui eram índios kadiwéu. A diretora Lúcia Murat lançou também, em 2015, o documentário A nação que não esperou por Deus, em que efetua uma comparação entre os antigos Eyiguayegui e os atuais Kadiwéu.

${ }^{73}$ Siqueira Jr. (1993: 108).

74. Viveiros de Castro (2002: 357-8).
} 
seres outros, fazendo alianças e convencendo-os a agirem conforme sua vontade, da mesma forma que os xamãs amazônicos. É por isso que, de acordo com Darcy Ribeiro (1980a: 200), os Kadiwéu ao mesmo tempo confiam e desconfiam dos unigene, pois qualquer um deles pode virar um feiticeiro (otxikonrigi), utilizando suas capacidades não mais para curar, mas para fazer os "bichos" atacarem seus inimigos.

Como demonstrado, o medo de "virar" outro - seja "bicho" ou "morto" - é constantemente demonstrado pelos Eyiguayegui e Kadiwéu. Também na descrição da festa da moça esse temor regula os comportamentos: como vimos, a menina não pode encostar no chão nem sair de sua cama para que não veja nenhum animal (e, consequentemente, seja atacada por ele). Além disso, ela não deve "se exaltar" para que não vire bicho. A reclusão a que a moça é submetida no momento de sua primeira menstruação - que é considerado extremamente perigoso - deve-se, portanto, à sua necessidade de proteção. No mais, ela não pode comer nenhuma carne ou gordura, alimentos que contêm muito sangue e que poderiam causar um acúmulo provavelmente fatal. Segundo Lecznieski (2005: 147),

[a] mulher menstruada deve abster-se de comer ou preparar carne, assim como o matador quando em período de reclusão, de domesticação do sangue/espírito do inimigo. O perigo é sempre o mesmo: 'virar bicho'. O acúmulo de sangue numa pessoa pode também deixá-la 'doida', 'fora do juízo', 'sem consciência.

Como lembrado pela antropóloga, o "sangue" eyiguayegui não é o mesmo que o "nosso", sendo denominado por ela "sangue/espírito" e carregando consigo memórias, capacidades e relações. O "acúmulo de sangue" a que Lecznieski se refere, nesse sentido, parece se referir ao contato demasiado com essas características de seres outros, que estão sempre à espreita, esperando para atacar. É importante notar que as restrições alimentares das mulheres, segundo um interlocutor de Pechincha, foram ensinadas aos Kadiwéu por Niwelanigi, aquele que transmitiu aos Kadiwéu seu modo de vida atual. Segundo essa narrativa ${ }^{75}$,

Niwelanigi deu conselho para moça. Quando vem a "primeira saúde" para a moça, ela não deve comer mel de jataí, porque é muito doce: 'o mel de jataí é bicho. Pode ver aquela abelha dele, é um bichinho, você comendo esse, olha, cuidado, vai te fazer mal. De repente vai, parece que está dando abelhada no rosto, mas não tem nada. Você comeu aquele, você não segue o meu conselho. Aí já está passando ruim, vai arruinar. É perigoso virar bicho também. Qualquer uma coisa de repente, parece que abelha está ali'. A moça também não pode comer carne de ema: 'aquela ema, você não come antes dessa saúde. Se comer carne de ema, você vai imediatamente ficar como ema, vai virar bicho. Não vai comer bicho, alguma carne. Come namocoli, come bacuri, come palmito, come coco, come farinha. Aquele é certo, até que você

\footnotetext{
75 Transcrita por Pechinha (1994: 95- 100) e apresentada no Anexo III.
} 
limpa. As mulheres não podem comer carne, só quando acaba, quando não vem mais. Senão, quando você morrer, você vai ficar como aquele bicho que você comeu'.

Além destes conselhos, Niwelanigi versa também sobre o comportamento dos enlutados e os animais que não devem ser comidos. Descrito pelo interlocutor de Pechincha como "primeira gente que tem capacidade" e considerado o "avô" de todos os Kadiwéu, Niwelanigi tem uma trajetória de vida interessante. Sua mãe, Nitikana, de quem os Matexua (uma das famílias nobres kadiwéu) descendem, fica grávida da onça e cria seu filho, durante seus primeiros anos de vida, longe dos costumes de sua família. Quando decide voltar à casa de seus pais, seus parentes não reconhecem Niwelanigi, dizendo que o filho de Nitikana era bicho. Grande parte da narrativa se dedica a contar como Niwelanigi se fez kadiwéu primeiramente deixando de comer carnes cruas e, depois, abandonando o costume de comer certos animais. Os ensinamentos que ele transmite ao final da narrativa são fruto de sua própria experiência de auto-construção como kadiwéu ${ }^{76}$.

Quando lida paralelamente às descrições apresentadas acima, a história de Nitikana e Niwelanigi acaba por iluminar os diversos dados acerca dos modos de vida eyiguayegui e kadiwéu. Em primeiro lugar, o fato de Niwelanigi, inicialmente um estrangeiro, transmitir os ensinamentos acerca de como ser kadiwéu é mais um exemplo ameríndio da constituição de um "si" a partir de elementos "outros". Em segundo, os conselhos presentes na narrativa mostram como a construção de um corpo adequado deve ser constante: todas as refeições, modos de agir e relações contribuem para a fabricação do corpo e os ensinamentos de Niwelanigi mostram que qualquer deslize pode ser um passo em direção a "virar bicho". Por fim, a história, quando lida em conjunto com os dados sobre a instabilidade do corpo eyiguayegui, apresenta a possibilidade de transformação que está dada a todos os corpos, que podem se transformar em "abelha”, "ema”, "morto" ou "bicho" - categoria que aqui certamente não designa animais tais como os concebemos, mas principalmente o que chamamos de “espírito”, e entre estes, particularmente os perigosos.

Nesse panorama, é perfeitamente possível que nibotagi virem niniotagi se construírem seu corpo e se comportarem de maneira adequada. É o que nos conta Rivasseau (1934: 170), que ficou hospedado na capitania do chamado "Capitãozinho Joãozinho" que, como o viajante descobriu ao longo de sua estadia, fora um cativo de guerra. Ele e sua mãe haviam sido capturados em uma expedição que os guerreiros

${ }^{76} \mathrm{O}$ que faz pensar no caso do vereador terena, cujo empenho em aprender a ser kadiwéu pode eventualmente fazer dele um kadiwéu exemplar. 
eyiguayegui haviam feito à sua vila em San Salvador e, quando Joãozinho tinha quatro anos, sua mãe morreu. Os Eyiguayegui, então, o adotaram e criaram "em seus costumes".

Mas, pouco a pouco, á medida que crescia, e desenvolvia a sua mocidade, os anciães da sua tribo adoptiva reconheceram nelle as aptidões e as qualidades que deviam alguns anos mais tarde, fazel-o considerar como um futuro chefe. Assim, chegou a ser braço direito do cacique Guazí-Âcâ e, emfim, cacique, chefiando uma pequena fração da tribu que, por motivos de segurança e também de conveniência material quanto á ocupação dos campos, havia motivado essa scisão (Rivasseau 1934: 170).

Guido Boggiani ([1895]: 116), que havia estado entre os Kadiwéu praticamente na mesma época que Rivasseau, também descreve o prestígio adquirido por Joãozinho e narra a "rivalidade" percebida entre ele e outro capitão, que se destacaria pela "pureza" de sua "raça":

É Joãozinho o personagem mais interessante da aldeia e sem dúvida o mais importante depois do Capitãozinho. Pode-se dizer que é um segundo chefe, havendo adquirido autoridade mediante sua inteligência e honestidade. [...] Creio ter notado uma certa rivalidade entre ele e o Capitãozinho. Este o supera pela nobreza e pureza da raça, mas Joãozinho tem inteligência maior e um senso mais acentuado de honestidade.

E Boggiani ([1895]: 43) se refere também a outro célebre "antigo" cativo que virou capitão, a quem o comerciante descrevia como "perfeito cão rosnador". De acordo com um relato colhido pelo médico alemão A. Fritch e transcrito por Baldus (1975: 37), Nawilo havia chegado ao posto de capitão depois de ter combatido na Guerra do Paraguai.

Naquele tempo, êle queimou a vila de São Salvador ${ }^{77}$. Capturou muitas pretas e mulheres guarani. [...] Êle salvou também o Forte Coimbra para os brasileiros. Atacou muitos transportes de abastecimento dos paraguaios. Os paraguaios passaram fome. Abandonaram o forte. Por isso, Nauvilla foi nomeado major da guarda nacional $[\ldots]$.

De acordo com um dos interlocutores de Pechincha, neto de Nawilo, o "antigo" cativo havia tomado a dianteira nas expedições da Guerra do Paraguai porque Capitãozinho era, na época, muito pequeno. De acordo com uma senhora kadiwéu,

O Capitãozinho chamou o Nawilo e disse: 'vem ver a situação dos portugueses nas mãos dos paraguaios. Eles já estão acabando com os portugueses. Eles só viram aquele derramamento de sangue dos portugueses na cidade de Porto Coimbra. O Nawilo falou para o capitão: 'vem depressa'. Mas até hoje a gente pode ver o Niwaga (João Matexua, filho do Capitãozinho) com o seu andar tão vagaroso. Esse era o costume do pai dele. O nosso capitão não era assim tão

\footnotetext{
${ }^{77}$ Interessante paralelo com a história de Joãozinho: talvez ele tenha sido "agarrado" justamente em uma
} das expedições lideradas por Nawilo, embora as fontes não façam essa conexão. 
apressado, ele era vagaroso. O nome do Capitãozinho era Exacaniwece. Ele usava os passinhos bem pequenininhos. Mas ninguém reclamava do andar dele. Ele era o nosso capitão. O Nawilo ia junto com os seus soldados. Ele era o GodapoaGenigi. Tinha o Capitãozinho e tinha o seu GodapoaGenigi, que era o Nawilo. E tinha os quatro ajudantes dele, tinha o tal do Niloiede (citou, em outro momento, o capitão Ajona, capitão de uma antiga aldeia, a Xatelodo, e um outro GodapoaGenigi de nome Ferraz). Eu quero contar para você que são quatro os GodapoaGenigi do Capitãozinho, que trabalharam para esta terra. Foram eles que trabalharam por este campo. $\mathrm{O}$ Nawilo é que era o maior ajudante do capitão. Os ajudantes disseram para o Capitãozinho: 'o senhor fica, não é bom o senhor ir junto, a gente poderia até deixar alguns homens para cuidar do senhor'. Ele decidiu ficar e o pessoal seguiu viagem. Eles foram invadir a cidade de Porto Coimbra (Pechincha 1994: 147-8).

Os dois interlocutores de Pechincha, percebe-se, trazem motivos diferentes para Capitãozinho não ter participado da Guerra do Paraguai. Segundo o neto de Nawilo, Capitãozinho era muito pequeno para participar de expedições guerreiras. Segundo a senhora kadiwéu, os "passos" de Capitãozinho eram "bem pequenininhos", o que parece indicar uma personalidade mais conciliadora e pacífica do que guerreira ${ }^{78}$. De qualquer modo, todos os dados disponíveis sobre o Capitãozinho e os dois "antigos" cativos Joãozinho e Nawilo parecem apontar para a mesma direção: nascer capitão não garante nem uma posição de liderança nem uma nobreza inquestionável. Em ambos os casos os "ex-cativos" se destacaram (pelo menos no que diz respeito à guerra e à capacidade de cultivar relações privilegiadas) em relação a Capitãozinho, o "nobre” por nascença. As qualidades guerreiras, a manutenção de determinadas relações e a qualidade de anfitrião podiam, nesse sentido, fazer nibotagi “virarem” niniotagi.

Por fim, é importante salientar que, ao mesmo tempo em que permitia que estrangeiros "virassem" eyiguayegui por meio do processo de incorporação, a instabilidade dos corpos chaquenhos (nisso tipicamente ameríndios) permitia, como vimos ao longo desta seção, que os corpos eyiguayegui se transformassem em corpos outros, potencialmente perigosos. E é por isso que, ao mesmo tempo em que se consideram os roubadores de crianças por excelência, os Kadiwéu demonstram o medo constante do rapto de suas crianças em diversas situações, segundo Lecznieski (2005:87). Grande parte de suas narrativas insistem, de acordo com a antropóloga, "no tema das crianças roubadas: no perigo que correm, o medo de perdê-las, a desobediência que as coloca em risco e o descuido dos pais". A história de Nitikana e de

\footnotetext{
${ }^{78}$ Não deixa de ser interessante o fato de que não apenas Capitãozinho, mas também seu pai e seu filho serem descritos como capitães de "andar tão vagaroso", sendo a guerra tão importante para a nobreza eyiguayegui. Faz pensar que, talvez, a chefia eyiguayegui fosse constituída por uma dupla em que um dos termos trazia a característica guerreira e o outro a da oralidade e capacidade de harmonizar as relações comunitárias. Essa hipótese, porém, não será levada adiante no presente trabalho.
} 
seu filho com a onça, Niwelanigi ${ }^{79}$, é um dos melhores exemplos desse evento tão temido: a irmã de Nitikana, Ebecalowai, foi roubada de seus pais pela onda do rio e a própria Nitikana foi roubada diversas vezes, conseguindo, em quase todas elas, retornar à sua tolderia. Nesse sentido, segundo Lecznieski (2005: 93), “[a] necessidade de cuidados extras" em relação às crianças

é explicado pelo perigo, sempre eminente [sic], de as crianças serem roubadas por seres que são, além do mais, especializados nesta tarefa. […] Os parentes das crianças, sobretudo suas mães, pais e avós sempre as advertem do perigo de se afastarem das casas ou perambularem por certos lugares.

Aliás, é interessante perceber que muitas vezes as mulheres são pensadas como propulsoras dessas metamorfoses iniciadas no roubo. Segundo a antropóloga, por exemplo, muitas narrativas kadiwéu mencionam mulheres que gostam de raptar crianças, "sendo interessante destacar uma velha que possui a vagina cheia de dentes afiados" 80 . É digno de nota o fato de que mulheres de vagina dentada como essas, que povoam grande parte da mitologia qom, como demonstra Tola (2012: 53-72), são responsáveis, segundo sua filosofia, por transformar os homens - que, antes de sua chegada, viviam em um espaço-tempo indefinido, reproduzindo-se por meio de jarros em que guardavam seu sêmen - em humanos. A chegada das "mulheres canibais", à terra, a retirada forçada dos dentes de suas vaginas e sua reprodução com os homensanimais são tidos muitas vezes como a origem do todos os qom. Segundo Tola, portanto, as mulheres são pensadas, ao mesmo tempo, como "anti-sociais" (por conta de seu ímpeto canibal) e como indispensáveis para o surgimento e manutenção da vida em comunidade.

Os dados acerca da mitologia kadiwéu não nos permitem afirmar que as mulheres são pensadas de maneira similar. Ainda assim, as informações sobre a participação das mulheres na guerra apresentados acima e discutidos na próxima seção são evidência de que, assim como entre os qom, as mulheres não são entendidas como seres "essencialmente" sociais ou "domésticos". Evidência disso é que Nitikana, uma das mais recorrentes personagens das narrativas kadiwéu, é admirada justamente por conta de sua coragem de sair de sua tolderia e estabelecer relações com o Fora. Além disso, algumas narrativas colocam as mulheres no papel de propulsoras da guerra. Discutindo com seus interlocutores kadiwéu a usual reprovação daqueles índios em relação à

\footnotetext{
79 Anexo III.

${ }^{80}$ Lecznieski (2005: 93). O motivo da "vagina dentada” é, como se sabe graças às Mitológicas de Claude Lévi-Strauss, recorrente na mitologia ameríndia.
} 
violência contra as mulheres, Lecznieski ouviu histórias que apontavam a guerra como uma reparação à agressão contra as mulheres:

Porque antigamente índio que bateu na mulher, aí já tem alteração, tem que pagar aquele motivo. A indiada faz reunião: 'vamos trocar ideia, vamos acompanhar fulano, fulano bateu na mulher. Ele quer pagar a conta'. Então indiada vai bater na outra indiada, por causa daquela alteração (Lecznieski 2005: 242).

Em outra narrativa, a esposa desafia seu marido a lhe trazer crianças:

'Tinha índio daqui que gostava de bater na mulher. Muito bravo com a mulher, qualquer coisa bate com o maneadorzinho. Então a mulher falou pra ele: 'você gosta de me bater com corda à toa mesmo. Eu quero que você acompanhe o pessoal e traga Chamacoco. Você não tem coragem, você gosta de me bater à toa'. E ele respondeu: 'Você vai ver, eu vou pegar, vou matar algum Chamacoco' (Lecznieski 2005: 242).

Ainda que homens e mulheres se engajem igualmente na criação das crianças ${ }^{81}$, as mulheres parecem ser pensadas muitas vezes como o motivo da busca pelos cativos e, consequentemente, pelo roubo e pela guerra. A antropóloga Beatriz Vitar (2001: 236-7) faz uma afirmação similar quando discute o olhar missionário sobre as mulheres chaquenhas:

Las mujeres, que deberían ser menos bárbaras, más dulces y compasivas por su índole, no pocas veces se muestran más crueles que sus maridos; ellas los mueven y excitan no como venganza, más bien como diversión, a llevarles de regalo un cráneo, la cabeza entera o la cabellera humana enemiga, para poder bailar en las indicadas fiestas [as festas dos escalpos discutidas abaixo] con elle en la mano.

Aliás, para além de incentivarem as expedições guerreiras, as mulheres estavam também presentes em muitas delas. Como demonstro na seção a seguir, as narrativas chaquenhas colocam em cheque a suposição (presente desde a documentação colonial até os dias de hoje) de que a guerra é estritamente masculina.

\subsection{Arte, Guerra e Bebedeira}

\subsubsection{As mulheres e a guerra}

Quando esteve entre os Eyiguayegui, entre os anos de 1889 e 1890, o francês Émile Rivasseau ficou hospedado na tolderia de Joãozinho e de sua primeira esposa, Jhivajhâá, uma tradicional dona eyiguayegui. O agrimensor e seu anfitrião gostavam de passar longas tardes conversando sobre o passado glorioso daquela nação e das lutas contra o proprietário das terras do Barranco Branco, português ex-militar que

\footnotetext{
${ }^{81}$ Lecznieski (2005: 222).
} 
expandia seus domínios invadindo suas terras. As tardes que os dois levavam à sombra das aroeiras eram regadas a chimarrão, estímulo para as perguntas do forasteiro, que desejava saber sobre os feitos guerreiros de seu recém-amigo. Quando questionado sobre suas expedições às terras inimigas, porém, Joãozinho dirigia a maior parte de suas elogiosas palavras à sua mulher, Jhivajhâá. Mesmo quando contava de incursões das quais ele mesmo havia participado, sua atenção recaía sempre sobre seus feitos, fazendo Rivasseau reconhecê-la como uma célebre bebedora e pintora. Em uma dessas tardes, Joãozinho elogiou muito sua esposa que, "muito corajosa e dedicada”, havia lhe salvado "várias vezes a vida, em circumstancias mui graves e até trágicas, quando a sua nação era perseguida pelas autoridades policiaes de Corumbá e do Estado e da gente do temível e descaridoso Portuguez, seu vizinho"82.

Se antes dessas digressões o agrimensor tendia a descrever Jhivajhâá como uma ótima dona de casa, e até como "mais ou menos uma escrava" a quem eram atribuídos os "trabalhos mais duros e mais penosos", depois de ouvir os causos de seu anfitrião Rivasseau passou a descrevê-la como "uma verdadeira amazona”. Segundo seu relato, Jhivajhâá "montava a cavallo como o melhor dos cavaleiros de sua tribo e em qualquer animal $[\ldots .$.$] , que ella mesma laçava, se preciso, com tanta destreza como o teria feito o$ melhor e mais hábil 'cow-boy”. Além disso, ela era,

\section{[… segundo se dizia, de uma habilidade notável para atirar com as espingardas que grande parte dos homens de sua tribu possuíam. Mulher incançavel. Foi, pois, em diversas circumstancias, que Jhivajhâá arriscou várias vezes a sua vida para salvar a do seu marido e também para impedir a destruição de sua tribu e a dispersão do resto dos seus membros (Rivasseau 1934:118).}

A sorte dos Eyiguayegui parecia, segundo a tradução de Joãozinho feita por Rivasseau, estar nas mãos da bravura e da coragem de Jhivajhâá. Segundo ele, sua "resistência physica havia sido provada muitas vezes pela sua própria vontade e, também, muitas vezes com risco de sua própria vida, tão grande era o devotamento que tinha para com a sua tribu e particularmente para com o Joãozinho, seu marido”. Corria pelas tolderias a história de quando Jhivajhâá, sozinha, conseguira espantar os soldados do governo brasileiro que estavam a mando do dono de Barranco Branco, salvando a vida de todo seu povo ao colocá-lo "[ [...] em logar seguro, e evitando, de tal arte, que cahisse prisioneir[o] de tão implacáveis inimigos, e que seu chefe, o Joãozinho, sucumbisse sob os ataques dos agressores"83.

\footnotetext{
${ }^{82}$ Rivasseau (1934:97).

${ }^{83}$ Rivasseau (1934:119).
} 
Como mencionado, Jhivajhâá era de uma família considerada nobre e havia sido levada desde criança à fazenda do Barranco Branco para realizar serviços domésticos. Ela falava muito bem o português por conta de sua convivência com os brasileiros e ao longo da sua vida se aperfeiçoou nas técnicas da pintura, realizada no corpo, na cerâmica e nos couros. O forasteiro nos conta, em suas crônicas, das belíssimas pinturas que ela fazia em épocas de festa e da ocasião em que Jhivajhâá se encantou com os motivos da sela do seu cavalo e os copiou em um couro, integrando-os aos seus múltiplos motivos. Em meio a todas essas qualidades, Rivasseau encontrou apenas um defeito: o fato de ela nunca ter dado filhos ao seu marido Joãozinho, que teria se sentido obrigado a desposar outra mulher mais jovem para poder dar continuidade à sua linhagem.

Essa figura descrita por Joãozinho como única entre os Eyiguayegui encontra diversos paralelos em outros documentos históricos. A valentia de Jhivajhâá e sua prática guerreira em colaboração com o marido, por exemplo, podem ser comparadas à aproximação, frequentemente descrita pelas fontes, que as mulheres eyiguayegui construíam com seus inimigos visando ataques guerreiros. Como vimos, uma das estratégias do(a)s guerreiro(a)s eyiguayegui era o "oferecimento" das mulheres que, quando percebiam a fragilidade dos inimigos, orquestravam ataques devastadores. Além disso, o relato sobre Jhivajhâá permite traçar outros dois paralelos com as descrições sobre as mulheres eyiguayegui: a afirmação de que as mulheres apenas "seguiam" ou "acompanhavam" seus maridos na guerra, que se relaciona à leitura que muitos autores fizeram sobre o aborto, e a importância das mulheres velhas para a prática guerreira. Vamos aos dados.

Jhivajhâá, para espanto e decepção de nosso informante Rivasseau, nunca havia tido filhos, destino que nem de longe parecia se distanciar daqueles das outras mulheres eyiguayegui: o cuidado das mulheres jovens em não engravidar e os abortos realizados por elas era o que mais chocava os cronistas. De acordo com o militar Félix de Azara (1809:66), as donas haviam adotado o costume, "bárbara y casi increíble, de no criar ningun más que un hijo o una hija y matar todos los demás”. Os autores são quase unânimes em afirmar que as origens desse "terrível hábito" estavam na vontade dos homens, que "raras vezes deixa[va $] \mathrm{m}$ nascer de suas mulheres" seus próprios filhos $^{84}$. Rodrigues do Prado (1795:31) afirma, na mesma direção: “[o] marido ama ternamente a mulher: é verdade que bem pago fica, pois ella tem um desvelo excessivo em o agradar, tanto que, em se sentindo pejada, mata a criatura no ventre para que

\footnotetext{
84. Almeida Serra (1850:250).
} 
durante a criação da prole o não incomode [...]”. Rivasseau também argumenta no mesmo sentido: para ele, a falta de filhos de Jhivajhâá era fruto de seu devotamento ao marido Joãozinho.

Figura 7 - Jhivajhâá

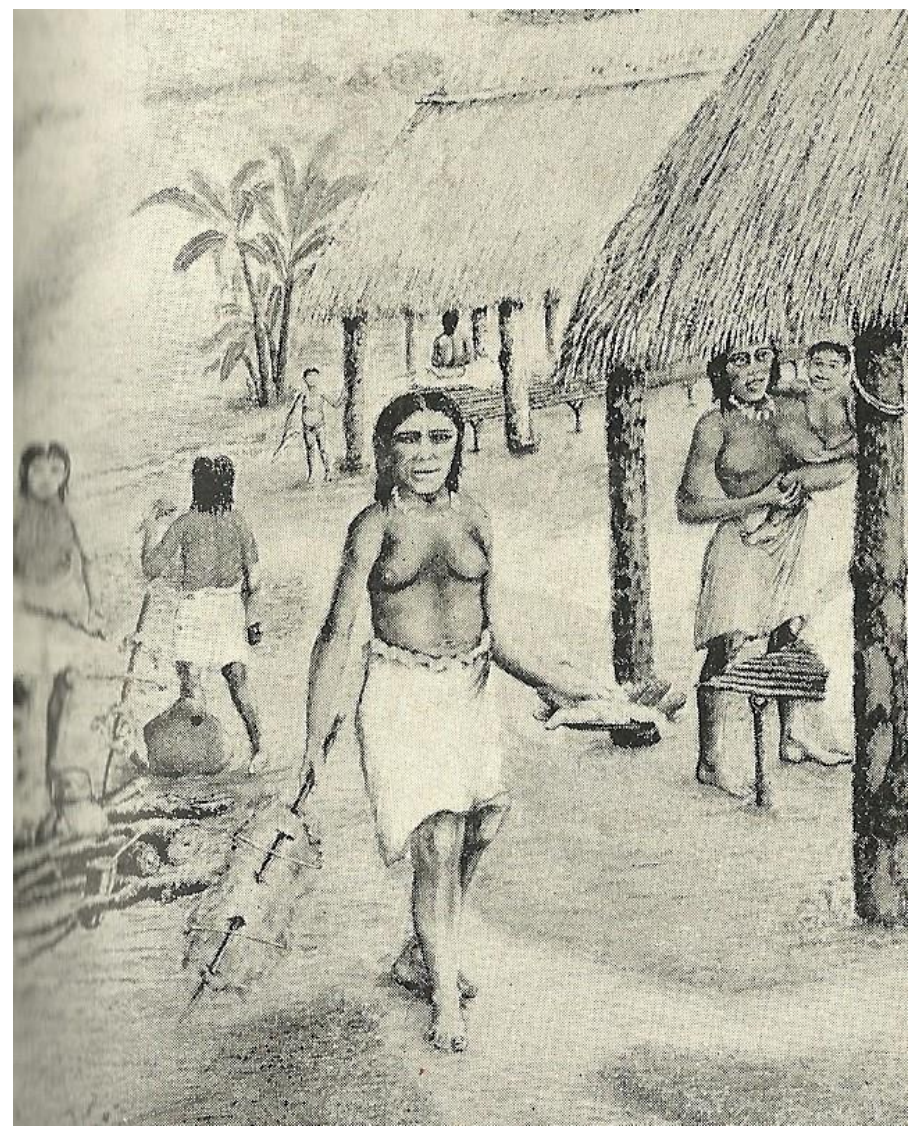

"Jhivajhâá levando nosso almoço".

Fonte: Rivasseau (1934: 120).

O "incômodo" que seria causado pela gravidez das mulheres eyiguayegui, por sua vez, é explicado de duas maneiras: primeiro, por conta dos resguardos que o casal precisava respeitar quando a criança nascia. Darcy Ribeiro (1980a: 69), por exemplo, sugere que o fato de as mulheres não poderem ter relações sexuais com seus maridos por no mínimo um ano depois do nascimento da criança era, "provavelmente, um dos fatores que tornavam o aborto e o infanticídio tão frequentes" entre os Eyiguayegui. Em segundo lugar está o motivo mais citado pelos autores: o fato de que os maridos queriam que suas mulheres os acompanhassem nas expedições guerreiras, o que seria dificultado por uma gestação ${ }^{85}$. Os homens, então, “obriga [ria $]$ m muitas vezes a que as mulheres mat[ass]em os filhos" 86 .

85 As mulheres, segundo Rivasseu (1936:72), obedeceriam a seus maridos por conta de seu amor inquestionável: "Á mulher, embora em todas as tribos indianas, lhes sejam atribuídos os trabalhos mais duros e mais penosos, e se considere ainda mais ou menos como escrava, não é attingida, no mais fundo 
Quando questionadas diretamente por Sánchez-Labrador ([1770-1776], v. I:478), porém, as donas não se remetiam à vontade de seus maridos para explicar seu "estranho costume" - respondiam, na verdade, que "nacieron para andariegos, que los muchos hijos son carga que no se puede transportar ni hay que darles de comer, y son demasiado embarazo para la guerra”. A atividade guerreira, nesse testemunho, não aparece de modo algum como atividade exclusivamente masculina que era apenas acompanhada pelas mulheres, mas como uma atividade também feminina: as mulheres a invocavam como motivo para não darem continuação às suas gestações, pois haviam "nascido para andarilhas". Os abortos, nesse sentido, eram "negócio de mulher", como afirma um interlocutor de Lecznieski (2005: 85).

No mais, é muito interessante a afirmação da mulher eyiguayegui sobre não poder "dar de comer" à criança que nasceria de sua gestação. Interpretada pelos cronistas como prova do ambiente pobre em que viviam e do consequente nomadismo daquela população, esses dizeres soam mais, a meu ver, como uma evidência de que a amamentação e a posterior criação dos bebês devem ser, como demonstrado, um processo cauteloso e exigente, ao qual a maioria das mulheres jovens não tinha tempo de se dedicar, por conta da participação em expedições de guerra.

De maneira parecida, atualmente muitas mulheres kadiwéu (principalmente as ceramistas) explicam o fato de terem poucos filhos por meio do argumento de que eles demandam muitos cuidados. "Criança precisa ser 'vigiada o tempo todo', dizem, e se tivessem muitos filhos, o trabalho na cerâmica seria prejudicado" 87 . O "trabalho na cerâmica", aliás, não envolve apenas a fabricação dos vasos de cerâmica, especialidade das mulheres kadiwéu, mas também as recorrentes viagens que elas precisam fazer para comercializá-las. Nessas viagens, elas se deparam, segundo Lecsnieski (2005: 221), com situações "muito distintas das que vivem na aldeia e que requerem, como uma delas observou, um 'espírito de aventura”. As mulheres kadiwéu, assim como as eyiguayegui, nesse sentido, postergam suas gestações para quando as expedições (guerreiras ou comerciais) se tornam mais escassas devido à sua idade.

A percepção de que as mulheres (nobres ou cativas) costumavam acompanhar seus maridos ou "senhores" nas expedições de caça e de guerra, aliás, é também defendida pela antropóloga Beatriz Vitar (2001: 238) que afirma, sobre outras "culturas

do seu amor-próprio, nem perdeu a sua natural sentimentalidade que pode manifestar-se de diversos modos. É preciso, pois, convir que há sempre nella, escrava ou não, predisposições particulares para manifestar a sua affeição, a sua dedicação, a sua amizade, e também o seu amor".

${ }^{86}$ Almeida Serra (1845:357).

${ }^{87}$ Lecsnieski (2005: 221). 
guerreras del Chaco” (principalmente populações de língua guaicurú) que as mulheres jovens iam para as expedições de caça e de guerra para coletar alimentos, uma atividade feminina, segundo a autora. De acordo com ela, este era um papel limitado às mulheres jovens:

Las mujeres que no tenían niños, acompañaban a los hombres en las operaciones guerreras para atender a su sustento y ayudar en el transporte de todo lo necesario: de las indias mocetonas antes de casarse', explica Lozano ([1873]), se valían los guaycurúes en las guerras para que 'les busquen raíces y cardos para comer', aunque el premio (botín) de una acción exitosa se lo llevaban las casadas (2001: 238).

A tarefa de coletar palmas e frutos parecia, também entre os Eyiguayegui, ser muitas vezes realizada pelas mulheres. Em certa ocasião, Boggiani ([1895]: 179), por exemplo, descreve o que ele denomina "Apêndice de Nalike", um acampamento provisório de algumas mulheres (e seus filhos) que, segundo elas, se devia à sua necessidade de "estar mais vizinhas do bosque em que abundavam os frutos de etchate e namocolli". A partida de algumas mulheres jovens chaquenhas para as expedições de guerra e caça em conjunto com os homens, porém, não deve ser explicada apenas por atividades de coleta que seriam concomitantes às de guerra: como sugere a própria antropóloga em outro artigo, “durante la recolección, los mismos utensilios que les servían para recoger frutos eran usados también por las abiponas para quebrar las armas y la cabeza de los enemigos"88 (Vitar 2015: 65). Nesse sentido, elas participavam das guerras não apenas coletando alimentos para seus maridos, como sugere inicialmente Vitar, sendo "igualmente caçadoras [e guerreiras] como os homens" 89.

No mais, a ideia de que as mulheres acompanhavam os homens à guerra acabou por fazer também com que os autores das fontes e antropólogos as descrevessem muitas vezes como "concubinas" ou "amantes" dos guerreiros, como se depreende da afirmação de Lévi-Strauss (1996:192), que baseou seus escritos sobre os Kadiwéu na documentação colonial:“[...] às vezes as adolescentes preferiam seguir os guerreiros em suas aventuras; serviam-lhes de escudeiros, pajens e de amantes”. Não é preciso afirmar que essa leitura efetuada pelos autores das fontes é apressada, levando em conta todos os dados que seus próprios relatos traziam sobre a participação das mulheres na guerra.

Por fim, é digno de nota o fato de que, em grande parte desses relatos, as mulheres que vão para a guerra são as mais novas. E mesmo os abortos eram restritos

${ }^{88}$ Dobrizzofher ([1784], v. II: 116).

${ }^{89}$ Almeida Serra (1850:353). 
às mulheres ainda jovens, que não haviam completado os trinta anos. Depois dessa idade, segundo as crônicas, elas "queriam conceber e se dispunham a criar"90, acompanhando felizmente o crescimento de seu filho. Não eram todas as mulheres eyiguayegui que "abortavam" por serem andarilhas, portanto: as mulheres maduras levavam a cabo suas gravidezes e criavam não apenas seus filhos, mas também aqueles que as mulheres jovens haviam parido e não criavam por conta de sua ocupação guerreira.

\subsubsection{As "velhas" e as borracheiras}

Como vimos, as "velhas" eyiguayegui tinham papel central em grande parte das festas. Na festa da moça realizada pelos Kadiwéu e descrita no início do capítulo, são elas as responsáveis por "transmitir" suas qualidades à menina púbere. Por seu conhecimento dos cantos e danças, além da maestria nas artes da pintura corporal, na confecção da cerâmica e dos tecidos (vimos que Jhivajhâá era uma célebre artista), as mulheres maduras e as "velhas" são muito respeitadas. Mas, se algumas das etnografias atuais tendem a construir uma ideia de senhoras que se dedicam à família e aos afazeres "domésticos" 91 , os dados trazidos pelas fontes históricas pintam uma imagem bem diferente (ainda que à revelia de seus autores).

A dança realizada por elas na ocasião do nascimento do capitãozinho é um dos exemplos: como demonstrado, elas se apresentavam, durante sete dias, vestidas como guerreiras, tocando flautas, portando arcos e flechas e demonstrando comportamentos agressivos. No mais, as "lutas", ou jogos de soco por elas realizados, bem como os cantos de guerra entoados por elas nas bebedeiras, também destoam da imagem de senhoras dedicadas apenas ao cultivo da harmonia.

As descrições das festas, aliás, nos fazem ver que a guerra não acabava quando o(a)s soldado(a)s voltavam das tolderias: ela era constantemente reativada pelas velhas, que utilizavam as cabeleiras e as cabeças em suas danças, nas quais elas se "travestiam", de acordo com Lévi-Strauss (1996:189). Ainda que não se lançassem mais às expedições

\footnotetext{
90 Almeida Serra (1845:357).

91 Jaime Siqueira Jr. (1993: 157), por exemplo, ao discutir a “divisão sexual do trabalho” entre os Kadiwéu, afirma que as mulheres, por conta de sua ocupação com o artesanato, "contribuem mais para a economia doméstica”. Em relação às reuniões que definem, segundo ele, os rumos políticos da comunidade, o autor que escreve que "as mulheres [...] raramente participam desse tipo de reunião e evidentemente são inelegíveis para qualquer função política. Exercem entretanto uma razoável influência junto aos homens no âmbito doméstico e através da difusão de boatos pela aldeia” (Siqueira Jr., 1993: 142). Resta saber quais evidências são consideradas pelo autor na construção da imagem de mulheres dedicadas apenas à "economia doméstica" e restritas a conversas com seus maridos e "boatos".
} 
guerreiras, portanto, as mulheres continuavam a ter um papel central na guerra (assim como os velhos "senhores" que eram os grandes conselheiros e chefes, muito escutados em momentos conflituosos), o que é evidenciado não apenas pelas descrições dessas danças, mas também das cerimônias em que os jovens capitães eram "condecorados" chefes de guerra e da recepção do(s)s guerreiro(a)s que voltavam das expedições. Segundo o relato de Rodrigues do Prado (1795:39), quando um jovem capitão debutava em sua primeira incursão a esteiras inimigas, era sua mãe quem recebia os cumprimentos de todos. Nessas ocasiões, essas velhas, "com voz alta e entoada, e os olhos nadando em lagrimas, começa [va $] \mathrm{m}$ a repetir as acções famosas de seus antepassados, exhortando-o [seu filho "neo-soldado"] a imital-os, e antes morrer do que fugir".

Ainda de acordo com o capitão português, quando as expedições voltavam,

as mulheres e as captivas $[\ldots]$ toma $[\mathrm{va}] \mathrm{m}-\mathrm{lhes}$ as armas e as presas; $\mathrm{e}$ se foram bem sucedidos, faz [ia $] \mathrm{m}$ muitas festas. A mãi do rapaz que aprisionou ou matou pela primeira vez [era $]$ obrigada a fazer maiores festas, e da[va] regalos ás outras; e por esta vez todos se embriaga[va $] \mathrm{m}[\ldots .$.$] (Rodrigues do Prado 1795:40).$

É interessante notar, nessa citação, que as festas oferecidas pelas mães dos guerreiros, bem como suas danças e cantorias reativavam e movimentavam a guerra eyiguayegui ao exaltar as qualidades de seu filho e de toda(o)s a(o)s guerreiros de sua tolderia. A guerra, nesse sentido, não se fazia apenas nos momentos das incursões realizadas a outras tolderias, mas também em suas festas92. E não apenas as "velhas" eyiguayegui foram descritas em suas exortações à guerra: elas pareciam estar no epicentro da prática guerreira em grande parte do Chaco. O missionário Martín del Barco Centenera (apud Vitar 2005: 62), por exemplo, se referia a uma "india muy vieja que exhortaba a los jóvenes guerreros chiriguanos a hacer la guerra a las colonias".

Aliás, é importante notar que também entre os Tupinambá as "velhas" tinham um papel muito importante, sendo "as mais vorazes devoradoras da carne do inimigo" 93 nas festas de antropofagia e participando, diversas vezes, de sessões de cura ou rituais xamânicos. No caso tupi, segundo Sztutman (2012: 419), as "velhas" descritas pelos cronistas pareciam ser aquelas mulheres "em idade provavelmente correspondente à fase da menopausa, ou seja, mulheres inférteis, que não mais menstruam”. Essa observação, de acordo com o autor, é de grande importância: segundo ele, o sangue é,

\footnotetext{
${ }_{92}$ A presença constante da guerra na festa é ressaltada por Perrone-Moisés (2015) como característica ameríndia; entre festa e guerra, que a autora propõe como as duas "grandes matrizes relacionais" ameríndias, as relações não seriam de exclusão mútua, devendo ser compreendidas à luz do "dualismo em perpétuo desequilíbrio" cf. Lévi-Strauss (1993).

${ }^{93}$ Sztutman (2012: 419).
} 
em muitos contextos ameríndios, pensado como fonte de perigo e descontrole, o que explica, em muitos casos, as restrições alimentares e reclusões experimentadas pelas mulheres em período menstrual. Ainda de acordo com Sztutman, a menstruação seria, ao mesmo tempo, fonte de "uma espécie de empoderamento" e evidência da "incapacidade de reter essa substância poderosa”, o sangue. As mulheres velhas, nesse sentido, seriam aquelas que, por conta de sua experiência, controlariam sua saída, podendo se colocar em situações de risco (aquelas em contato com o Fora), assim como os xamãs.

O papel propulsor da guerra encarnado pelas mulheres "velhas" eyiguayegui parece seguir princípios similares. Como demonstrado, também entre os Eyiguayegui o sangue era uma substância poderosa e, nos períodos de menstruação, as mulheres deviam evitar ingerir animais que geralmente eram consumidos pelos outros, de modo a evitar o contato com seu sangue: de acordo com Rodrigues do Prado (1795:33), as mulheres jovens eram submetidas a muito mais restrições alimentares do que "os homens, as velhas e as meninas" (este é, aliás, um dos principais conselhos de Niwelanigi aos Kadiwéu). Para poderem participar das expedições guerreiras, portanto, elas precisavam preparar seu corpo, e sugiro que as restrições alimentares podem ser lidas, ao mesmo tempo, como uma maneira de contenção e de aprendizado gradual do controle da saída do sangue, controle este que as mulheres mais velhas já teriam alcançado.

Além disso, o caso chaquenho parece apresentar outra particularidade das mulheres maduras e/ou velhas: na citação de Vitar apresentada acima, a autora afirma que "el premio (botín) de una acción exitosa se lo llevaban las casadas", ainda que fossem as solteiras aquelas que partiam para as expedições. A afirmação da antropóloga se fundamenta na informação, encontrada por todo o Chaco, de que, ao chegar às tolderias com um cativo, o marido dava o escalpo/cabeça do inimigo ou o cativo à sua esposa. Mas parece haver também uma distinção etária: as "faceirices" das mulheres jovens eyiguayegui - nas palavras de Taunay (1934:44) - são muito conhecidas na literatura regional, e quando as mulheres, depois de alguns anos, se estabilizavam (ao menos por determinado período) em uma relação conjugal, é possível que elas adquirissem um estatuto diferente, assim como o guerreiro nivacle, que só podia ser considerado chefe se fosse casado e tivesse filhos, como veremos adiante. Ainda que essa seja uma possibilidade de interpretação dos dados eyiguayegui, é necessário lembrar que todas as mulheres "e principalmente as donas", segundo Almeida Serra (1845:356), tinham "um ou dois chichisbêos", que sempre andavam e dormiam ao seu 
lado, e dos quais "os maridos não tinham ciúmes, dizendo que eram para sua guarda e vigia, sendo algum d'estes chibantes o que ordinariamente casavam com ella quando o marido fazia o mesmo com outra mulher". O próprio casamento desses índios era considerado pelos autores uma "infiel fanfarronada" (Sánchez-Labrador [1770-1776], v. II:24), visto que o "divórcio" entre eles era muito comum e nada repreendido.

No mais, assim como as mulheres não-férteis tupinambá, também as eyiguayegui participavam das curas realizadas pelo unigene. Boggiani ([1895]: 144-5), por exemplo, conta da vez em que uma senhora acompanhou todo o processo de cura de três doentes, sendo responsável por avisar o momento do início e do término daquele "jogo astronômico-mágico" aos moradores da tolderia. Talvez por isso muitas das "velhas" chaquenhas tenham sido descritas pelos missionários como as mais avessas à evangelização e as mais dispostas a "convertirse em brujas" 94 . O missionário Martín Dobrizhoffer ([1784], v.. I: 148), por exemplo, descrevia as senhoras abipon ${ }^{95}$ como "obstinadas en sus supersticiones y amigas de los ritos bárbaros". Segundo Vitar (2001: 229), “[t]emerosos de su influencia, los missioneros les atribuyen un poder demoníaco basado en el terror que inspiraban al grupo; las viejas eran, sin más, 'hechiceras' que se ‘comunicaban' y ‘pactaban' con el demonio”.

Segundo Dobrizhoffer ([1784], v. III: 367), a assistência aos doentes era uma atribuição das mulheres velhas abipón, assim como a organização dos rituais funerários. Entre os Mocovi, segundo o missionário Paucke ([1743-1767], v.. II: 237 apud Vitar 2015: 69), "no ha de aparecer ningún hombre indio en la choza del moribundo, solamente mujeres y las indias más viejas". De acordo com Vitar (2015: 69), a "todas elas [as mulheres maduras e "velhas" chaquenhas] incumbía también excavar la tierra y enterrar a los muertos. En el trance de la muerte, los misioneros debieron luchar contra las ancianas a los fines de cumplir con el rito sacerdotal cristiano de asistencia a los agonizantes" 96 .

Essa posição de intermediária entre os mundos dos vivos e dos "espíritos", por sua vez, parecia se estender às relações entre os índios chaquenhos e os europeus. Vitar (2015: 64) conta, fundamentada nos escritos do missionário Pedro Lozano, da vez em que os espanhóis, tendo feito prisioneiros alguns índios malbalaes (Mbayá), deram a

\footnotetext{
94. Vitar (2015: 61-2).

${ }^{95}$ Grupo chaquenho de língua guaicurú que habitava o Chaco argentino.

96 Ainda que a antropóloga afirme que a atribuição de enterrar os mortos seja, em grande parte do Chaco, reponsabilidade das "velhas", não há dados que confirmem essa hipótese no caso eyiguayegui. Ainda assim, considero que o papel de intermediárias das velhas (evidenciado, no caso abipon, no tratamento dos moribundos e cadáveres) pode ser considerado um elemento pan-chaquenho, considerando os dados disponíveis.
} 
uma "india muy anciana" a missão de "transmitir a su pueblo la invitación española a reducirse".

$\mathrm{Al}$ enumerar el séquito de figuras que acompañaron al cacique "principal" de los malbalaes para celebrar la paz, el cronista [ o padre Lozano] destacaba a la anciana portavoz, bautizada por los españoles como "la Conquistadora" en virtud de sus buenos oficios para llegar al acuerdo. Este interesante episodio de guerra y paz fronteriza revela el notorio protagonismo de la tal 'vieja' […] (Vitar 2015: 64-5).

É digno de nota o fato de que também Jhivâjhâá era "porta-voz" dos Eyiguayegui entre os brancos: de acordo com Rivasseau, ela havia passado grandes períodos na fazendo do Barranco Branco, sabendo falar muito bem o português.

Por fim, esse papel de "intermediárias" entre vivos e "espíritos", índios e nãoíndios, que lhes conferia habilidades para se relacionar com o outro ou para "llegar al acuerdo", como escreve Vitar, também é encontrado na relação com os cativos. Dobrizhoffer afirma, sobre a relação das "viejas cacicas" abipon com os "prisioneiros de guerra”:

He aquí dos ejemplos: la anciana esposa del cacique Alaykin preparó y equipó el caballo de un cautivo negro en presencia mía. Otra viejecita, madre del cacique Rebachigui, cedió su lecho, durante muchas noches a un niño enfermo, tendiéndose ella pobremente día y noche en el suelo. Por esta facilidad y deseo de agradar tienen obligados moralmente a los prisioneros de tal modo que aunque tengan diaria oportunidad de huir nunca lo hacen ya que están contentos con su suerte (Dobrizhoffer [1784], v. II: 149 apud Vitar 2015: 64).

O missionário interpreta o tratamento dedicado pelas senhoras a seus cativos como uma forma de impedir que fugissem mas, como demonstrado, os cativos chaquenhos eram, via de regra, muito bem tratados, e as "velhas" pareciam ser suas melhores companhias. Taunay (1931:21), como vimos, afirmava sobre os Eyiguayegui que os "captiveiros" tinham direito "até [a] regalias especiaes. Irá a senhora buscar agua á fonte a lavar a roupa que pertença ao escravo, mas nunca o obrigará a estes serviços!”. No mais, a leitura das fontes indica que as "senhoras" eram as pessoas que mais se casavam com cativos. Vale lembrar que Jhivajhâá, a personagem principal de nossa história, era casada com Joãozinho, capturado de um aldeamento guarani quando tinha apenas quatro anos. De acordo com Cabeza de Vaca ([1555]:159), as capitãs possuíam "maior liberdade do que a concedida às espanholas", possuindo também "o direito de libertar o prisioneiro que os homens traz[ia $] \mathrm{m}$ para junto deles, podendo este até continuar a viver entre eles, se quise[sse], passando a ser tratado como se fosse um integrante da tribo". As donas eyiguayegui, nesse sentido, eram descritas também como transformadoras da condição dos cativos, convertendo, através do casamento, "antigos" cativos em capitães. 
Nesse sentido, a leitura das descrições presentes nas fontes sobre os Eyiguayegui faz parecer que eram essas mulheres maduras e as "velhas" aquelas que mais tinham fome de cativos e crianças: como afirmado, era o "furor de las viejas" 97 que excitava o(a)s jovens guerreiro(a)s a trazerem-lhes cabeças ou escalpos. Esse "botim de guerra" - o objetivo mesmo das expedições guerreiras - era, portanto, trazido para as mulheres maduras e velhas: as crianças capturadas eram criadas por elas, os cativos homens se casavam com elas e os escalpos, como vimos, eram primordiais nas danças por ela realizadas.

O melhor exemplo das danças com os escalpos realizadas pelas "velhas" chaquenhas é aquele trazido por Adriana Sterpin (1993) em seu artigo sobre os Nivacle. De acordo com a autora, antes mesmo de os guerreiros chegarem com os escalpos/ cabeças de seus inimigos, as mulheres recebiam uma mensagem e já começavam a preparar a tôtônche - palavra que significava, segundo Sterpin (1993: 42), "elas dançam com os escalpos". Quando os guerreiros finalmente chegavam, as "velhas" logo se agarravam às cabeças/escalpos, dirigindo-se à praça central e fazendo voltas ao redor da aldeia enquanto cantavam. Segundo a autora, apenas as mulheres que haviam passado pela menopausa podiam dançar com os escalpos/cabeças e os cantos, exclusivamente femininos, só deviam ser entoados pelas senhoras de idade. É interessante notar que esses cantos, de acordo com Sterpin (1993: 42), eram adquiridos no contato com a cabeça, que nesse primeiro momento ainda estava ensanguentada e, por isso, não podia ser aproximada das mulheres jovens. As danças que as velhas realizavam com os escalpos, por sua vez, tinham elementos perceptivelmente eróticos, assim como aquelas realizadas entre os qom (denominados por Sterpin como Toba), em que as mulheres passavam os escalpos de mão em mão, revezando o que chamavam de "marido" e passando-os em seus genitais ${ }^{98}$.

As danças das "velhas" nivacle duravam aproximadamente um mês, enquanto o escalpo secava e o matador ficava em reclusão tentando "controlar" o espírito do inimigo, como descrevo na próxima seção. Quando o escalpo finalmente secava, organizava-se uma grande borracheira a que diversas aldeias vizinhas eram convidadas. Um dos pontos altos dessa festa era o momento em que o escalpo era transformado em um recipiente de bebida ${ }^{99}$ e, depois, quando o matador entrava na aldeia com seu cavalo ornamentado, um cocar vermelho, mulheres jovens à frente e

\footnotetext{
97 Sánchez-Labrador ([1770-1776], v. I: 311$)$.

${ }^{98}$ Sterpin (1993: 42).

99 Sterpin (1993: 45).
} 
mulheres velhas atrás. Nessas ocasiões, as velhas bebiam, assim como os matadores, dentro dos escalpos e incitavam, com seus cantos, a bravura dos guerreiros nivacle ${ }^{100}$.

Anos depois, quando os escalpos começavam a envelhecer e a perder cabelo, os insetos começavam a chegar e não havia como beber nada dentro deles, os matadores, geralmente já idosos, faziam uma festa para se despedir de seus troféus e de seu título de grandes guerreiros. Nessa festa, as velhas roubavam todos os ornamentos que indicavam seu status de caanvacle, nobre matador: seu cocar, seu tambor, o escalpo e até mesmo os couros de cervo em que ele se sentava.

Esta apresentação resumida do ciclo de festividades guerreiras nivacle é suficiente para efetuar uma série de comparações com as festas (e com as mulheres maduras/"velhas") eyiguayegui. Os cantos de guerra "ensinados" às "velhas" nivacle pelos escalpos dos inimigos, por exemplo, remetem diretamente àqueles cantos entoados pelas eyiguayegui nas festas descritas. Como não há dados sobre a "origem" destes cantos, não é possível afirmar que eles também sejam aprendidos de Outros, mas esta parece ser uma leitura possível, uma vez que, também no caso eyiguayegui, apenas as velhas (aquelas que têm um corpo mais forte para o contato com o sangue/espírito estrangeiro) podem cantá-los. Além disso, o papel de “intermediárias” das senhoras eyiguayegui também pode ser comparado ao papel das senhoras nivacle. Segundo Sterpin (1993: 48), as ações das "velhas" estavam sempre a ultrapassar fronteiras, sendo portanto extremamente ambíguas: os momentos em que as "mães e avós estéreis" imitavam a atitude de mulheres jovens com seus amantes, ou bebiam nos escalpos como se fossem nobres guerreiros, seriam exemplo disso. No mais, o fato de as maduras e velhas serem figuras centrais tanto no momento de entrada dos escalpos/cabeças nas aldeias quanto no de saída (quando os escalpos/cabeças eram enterrados ou dados às senhoras), interpretado por Sterpin (1993: 48) como evidência de que elas tinham autoridade sobre sua circulação, remete à relação privilegiada que as "velhas" eyiguayegui tinham com os cativos e com as cabeças trazidas às tolderias. Por fim, o papel ativo das senhoras nivacle nas bebedeiras é similar à participação assídua das "velhas" eyiguayegui nas borracheiras: segundo Boggiani ([1895]: 231), elas eram centrais nessas ocasiões e "as mais brilhantes bebedoras de pinga".

Assim como as bebedeiras nivacle, as eyiguayegui estavam intimamente relacionadas à guerra. De acordo com Sánchez-Labrador ([1770-1776], v. II:4), durante a bebedeira tocava-se um berrante e um menino "vestido de gala" tocava o tambor e cantava, “celebrando el valor de los bebedores”. O missionário relata que as 
bebedeiras eram "quase transcendentais" para homens e mulheres: depois de horas bebendo, os participantes começavam a

[‥] se lamentar e a chorar, não pelas dores físicas que experiment[assem], mas falando de graves injustiças que lhes haviam sido feitas ou de desgraças sofridas, e chora[vam] e se lamenta[vam] com vozes lastimosas, enquanto os da casa procura $[\mathrm{va}] \mathrm{m}$ consolá-lo o melhor que $\operatorname{pod}[\mathrm{ia}] \mathrm{m}$ e algumas vezes acaba[va]m por acompanhá-los nas suas lamentações (Boggiani [1895]:165).

Segundo o(a)s interlocutore(a)s do missionário, ele(a)s bebiam “[ [..] para dormir, y ver en sueños cosas nunca vistas, fiestas, juegos, y delicias" e para sentir, ainda em sonhos, "lindos sabores de comidas y bebidas". Depois de acordar e "se lamentar”, então, ele(a)s voltavam a beber até que as celebrações chegassem a seu fim.

É digno de nota o fato de que, em algumas descrições, o papel de "copeiro(a)" era realizado pelas mulheres e, em outras, pelos cativos. Como afirmado no capítulo anterior, essa atribuição foi muitas vezes vista como um sinal de inferioridade: aqueles que não "poderiam" beber seriam, de acordo com essa leitura, subalternos. Mas, aparentemente, diferenciações desse tipo também aconteciam entre os Nivacle e não eram necessariamente vistas como hierárquicas. Segundo Sterpin (1993: 46), aqueles que não bebiam e ficavam atentos aos "acessos de raiva" dos bebedores, prontos para acalmá-los, recebiam deles presentes, o que parece indicar outro tipo de relação. Já de acordo com Vitar (2015: 65), na maior parte dos grupos de língua guaicurú, as "velhas"

también disfrutaban del privilegio de consumirla, mientras el resto de las mujeres debía abstenerse - salvo entre los lules y los mocovíes -, manteniéndose así en un estado de sobriedad que les permitía desempeñar una función de control social, actuando como moderadoras en las riñas masculinas producidas tras el consumo de alcohol.

Não há dados que afirmem que as mulheres eyiguayegui e seus cativos efetuavam um "controle social" durante as borracheiras, mas pensar em suas atribuições como as de mestre(a)s de bebedeiras (uma leitura que, sugiro, parece ser possível) faz emergir outros tipos de relações que não as "hierárquicas". Como vimos, na festa da moça o(a)s cativo(a)s são aqueles que administram a festa e as atribuições de cada um, papel de extrema importância para o andamento da celebração.

Presentes em praticamente todos os relatos sobre os povos chaquenhos, as bebedeiras estavam, como afirmado, intrinsecamente relacionadas à guerra. Segundo Sterpin (1993: 52), não havia, no Chaco, uma época específica considerada propícia à atividade guerreira. Mas havia um período em que as festas eram abundantes: na estação da chuva, quando as frutas silvestres e a algarroba cresciam mais e as bebidas 
alcoólicas eram feitas com mais facilidade, quase não havia intervalo entre uma bebedeira e outra. A realização desenfreada de borracheiras, por sua vez, fazia com que os ânimos se exaltassem, cantos de guerra fossem entoados lembrando os inimigos e exaltando a bravura dos "soldados" e, consequentemente, as expedições guerreiras ficassem mais frequentes. Nessas épocas, o Chaco se transformava em um campo de batalha e não havia o que impedisse o ímpeto guerreiro de homens e mulheres, potenciais captores e cativos.

A "fome de crianças" e de cativos que fazia o tempo chaquenho se movimentar também fazia bebedeiras e expedições guerreiras, festa e guerra, se entrelaçarem. Além disso, fazia com que se cruzassem aquilo que as análises antropológicas denominam "arte e guerra". A guerra, como demonstrado, estava repleta de manifestações que poderíamos classificar como artísticas: cantore(a)s, flautistas, tamborileiros, pinturas corporais... E mesmo a arte parecia se pautar pela guerra: todas as descrições de cantos, por exemplo, remetem a feitos guerreiros; em conjunto com o som dos tambores e flautas, ouvia-se também a exaltação dos bravos "soldados" eyiguayegui. Os dados trazidos pelas fontes, nesse sentido, não permitem afirmar que havia uma divisão entre o que nós entendemos como dois domínios separados e, muito menos, que a "guerra" se relacionava aos homens e a "arte" às mulheres. A participação das mulheres, jovens, maduras e idosas, na guerra e nas festas é evidência disso, e a arte dos guerreiros chaquenhos, discutida na próxima seção, nos permite seguir na mesma direção.

\subsubsection{Os homens e a arte}

Na nossa tribo, os homens são escultores e as mulheres são pintoras. Os homens modelam na madeira dura e azulada do guaiáco os santos que falei mais acima; também decoram em relevo os chifres de zebu que lhes servem de xícaras, com figuras de homens, emas e cavalos; e ocasionalmente desenham, mas sempre para representar folhagens, seres humanos ou animais. Às mulheres estão reservadas a decoração da cerâmica e das peles, e a pintura corporal de que algumas são virtuoses incontestes (Lévi-Strauss 1996: 173).

Nem todos os antropólogos relacionam as artes apenas às mulheres. LéviStrauss, por exemplo, afirmava que a diferença entre masculino e feminino, no que se referia à arte, seria aquela entre o representativo e o abstrato, a escultura e a pintura. Lecznieski (2005: 194-5), por sua vez, escreve que atualmente os homens não esculpem mais, "embora teçam, eventualmente, chapéus de palha e pelegos para montaria". Já as mulheres "continuam produzindo uma arte plena de significados abstratos e de grande valor simbólico”. 
A arte masculina a que me dedicarei nesta seção, porém, não é nem a escultura nem a tecelagem. Como descrito no capítulo anterior e no início deste, os homens tinham também outra maneira de expressar seu talento artístico: a música, presente em diversos momentos de suas vidas e que inclusive compunha seu ciclo de aprendizagem. Vejamos.

As descrições das expedições guerreiras, como exposto, estão repletas de menções aos músicos: os flauteiros que avisavam o movimento dos inimigos e indicavam o melhor caminho, o tocador de berrante que espantava os adversários... Também nas festas a música estava presente: vimos que, na celebração do nascimento do capitãozinho, os nachigue tenagadi tocavam a corneta, o chocalho e o tambor dia e noite, o "velho nibotagi" cantava canções durante os oito dias de festa e, também por toda a duração do octavário, um menino tocava tambor em frente à entrada da tenda em que estava fermentando a bebida alcoólica.

Embora nenhuma fonte se detenha sobre as práticas musicais masculinas, é possível entrever, nas entrelinhas de suas descrições, que os momentos em que os meninos tocavam o tambor e a corneta eram de extrema importância. Aliás, ser um bom tamborileiro parecia ser uma das etapas percorridas pelos meninos para se tornarem guerreiros. Sánchez-Labrador ([1770-1776], v. II: 9), por exemplo, faz uma conexão direta entre a festa de iniciação masculina descrita acima e a constituição da "clase de muchachos a que se llama Nachigue Tenagadi", os tamborileiros. Como demonstrado, em sua festa de iniciação, os meninos passavam uma noite inteira tocando o tambor e cantando. Segundo o missionário, os meninos que haviam passado por esta prova (e também pela perfuração com o dente de onça) podiam se tornar tamborileiros, sendo responsáveis por tocar nas vindas de outros caciques, saídas de expedições guerreiras e outras bebedeiras: este era, segundo Sanchez-Labrador, "el instrumento ordinário en sus fiestas"101. Quando chegava um capitão ou seu parente, o nachigue tenagadi logo se aprontava:

Dispuesto el tambor; se sienta cruzadas las piernas, teniendo delante el dicho instrumento; coge en la mano derecha un palillo, con que le toca, dando unos golpes en medio; y á pausas tal cual en la orilla. En la mano izquierda tiene un calabazo en el cual hay unas frutillas duras, y le mueve sin cesar, causando una disonante aromnía con el refregarse contra la certeza interior y entre sí las frutillas. Tienen nombrados los sones, como el Gallinazo, el del Tigre, etc. Canta y toca á un mismo tiempo, ensalzando las prerrogativas de su huésped (Sánchez-Labrador ([1770-1776], v. II: 9).

${ }^{101}$ Sánchez-Labrador ([1770-1776], v. II: 9). 
Esta cerimônia, afirma o missionário, era indispensável e, por isso, antes de visitar outras tolderias o cacique mandava avisar sua chegada ao menos quatro dias antes $^{102}$.

Sobre as canções dos "soldados" já mais velhos temos muito menos informações, como aquelas a respeito dos guerreiros flautistas e dos tocadores de berrante que podem ser pinçadas nas descrições das expedições guerreiras. Adriana Sterpin, por sua vez, registra diversas narrativas acerca do canto masculino nivacle. Segundo a autora, os cantos presentes nas festas dos escalpos (apresentadas na última seção) marcavam a sequência de mudanças de status pelas quais passavam os guerreiros ao longo de suas vidas.

A primeira celebração, que acontecia quando o jovem trazia o escalpo/cabeça para sua aldeia, consagrava o captor como um guerreiro, o que também acontecia entre os Eyiguayegui, como demonstrado. Entre a primeira e a segunda festa, durante o período em que o escalpo secava e o sangue se esvaía, o matador ficava em reclusão. Nesse momento, ele passava, primeiro, por um processo de diferenciação do espírito inimigo, que ainda trazia em si. Além disso, era nesse período de “domesticação" do espírito do morto que ele aprendia seus cantos de guerra ${ }^{103}$. As canções ensinadas pelos adversários decapitados, segundo Sterpin (1993: 49), tinham o poder de aturdir os inimigos durante as expedições, além de fazer crescer a raiva e a cólera dos guerreiros nivacle antes da partida às aldeias estrangeiras e mesmo durante suas bebedeiras; segundo a antropóloga, são os cantos roubados que traçam a relação entre a festa e a guerra chaquenhas. Ainda de acordo com os dados de Sterpin (1993: 49), era apenas depois dessa reclusão e do roubo dos cantos (que provava a habilidade na relação com o inimigo) que os guerreiros podiam ser considerados caanvacle, ou chefes. A segunda bebedeira, então, celebrava a "nobreza" daqueles que haviam conseguido controlar seus adversários e roubar seus conhecimentos.

É digno de nota o fato de que, para se tornar caanvacle, o guerreiro nivacle precisava ser casado e ter filhos ${ }^{104}$. Os solteiros, segundo Sterpin (1993: 41), iam para a guerra e não matavam, apenas realizando tarefas auxiliares. Mesmo que eles tivessem a

102 O jesuíta conta também da vez em que um capitão chegou a uma tolderia estrangeira antes do previsto e os tamborileiros, pegos desprevenidos, não conseguiram chegar a tempo, o que gerou um malestar que demorou a ser resolvido.

103 A aproximação com o processo de “domesticação” do inimigo morto entre os Tupinambá é irresistível, mas não poderá ser explorada no presente trabalho. Para reflexões acerca da "imanência do inimigo” tupinambá, ver Viveiros de Castro (2002); Carneiro da Cunha \& Viveiros de Castro (2009) e Sztutman (2012).

${ }_{104}$ Interessante notar que os solteiros tupinambá, ao contrário, só conseguiam se casar e, portanto, serem pais, se mostrassem suas habilidades como matadores (Carneiro da Cunha \& Viveiros de Castro 2009: 82). 
coragem de matar um inimigo, eles não eram considerados fortes o suficiente para encararem a apropriação de um canto trazido pelo escalpo. Por isso os caanvacle eram muitas vezes considerados "um pai superlativo da comunidade". De acordo com Sterpin (1993: 42), o caanvacle se encontrava, em relação à sua gente, "em uma posição análoga àquela do adulto em relação à criança; nesse sentido, podemos dizer que, simbolicamente, ele é "mais homem", mais "adulto", "mais nivacle" que os nãocaanvacle".

O terceiro tipo de borracheira realizada pelos Nivacle era aquela em que o caanvacle, já mais velho, entregava todos os seus “distintivos": o escalpo, seu cocar, as peles de cervo e o tambor, que havia o acompanhado durante todo o seu percurso como guerreiro (como parecia acontecer também com os "soldados" eyiguayegui). Nesse momento, ele se tornava um qu'eishenaj, especialista nos cantos e responsável por cuidar da preparação dos escalpos e da instrução dos guerreiros mais jovens ${ }^{105}$.

Sugiro que os cantos masculinos eyiguayegui podem ser lidos em uma chave muito parecida com aquela proposta por Sterpin, ainda que as fontes sobre os Eyiguayegui não se refiram a cantos masculinos como os nivacle, provindos de inimigos e obtidos na reclusão do matador. A fala de Seu Tenório, interlocutor de Lecznieski (2005: 186), porém, faz pensar que o mesmo aconteceria entre eles. Ao explicar à antropóloga o motivo de os homens não cantarem mais, Seu Tenório diz que o guerreiro

'matava na hora, sem pedir explicação'. Não conversavam, 'senão começava o negócio de amizade, e aí ficava difícil'. Seu Tenório lamentou que, hoje, homem não canta mais, porque hoje, se faz alguma arte, tá lá a cadeia esperando por ele; hoje é assim, por isso homem não canta mais'. A arte a que se refere, é a arte de matar; e o canto, é o que costumava ser entoado pelo matador, no período em que ficava 'se limpando do sangue do inimigo'.

A distância que os guerreiros nivacle precisavam estabelecer em relação a seus inimigos durante a reclusão aparece, na fala do senhor kadiwéu, desde o primeiro contato com o adversário. Note-se que, segundo ele, se o guerreiro conversasse com a vítima, logo "começava o negócio de amizade, e aí ficava difícil”. Lida à luz de todos os dados sobre a "caduveização" dos inimigos, essa afirmação parece apontar para o fato de que, quando o inimigo não era logo morto, seu processo de aproximação e assemelhamento podia começar logo ali, no campo de batalha. No mais, a menção ao período em que o matador ficava "se limpando do sangue do inimigo" parece indicar um período de reclusão comparável ao do guerreiro nivacle.

${ }^{105}$ Sterpin (1993: 41). 
As informações disponíveis sobre os cantos masculinos eyiguayegui parecem apontar para a existência de, no mínimo, quatro tipos de $\operatorname{cantos}^{106}$. Primeiro, aqueles entoados pelos meninos que ainda não eram considerados guerreiros. Essas canções, segundo as fontes, enumeravam os feitos dos "soldados” já célebres. Segundo, aquelas cantadas pelos nibotagi: vimos que, na festa do capitãozinho, um velho nibotagi fazia previsões benfazejas por meio dos cantos. Esse dado é especialmente interessante, visto que, aqui é o próprio (ex-)inimigo, "caduveizado", que canta ${ }^{107}$. Terceiro, as canções entoadas no período em que a nudagi estava fermentando: os nachige tenagadi, como demonstrado, cantavam dia e noite à porta da cabana em que a bebida estava sendo preparada; sugiro que, possivelmente, os Eyiguayegui também relacionassem, assim como os Nivacle ${ }^{108}$, o processo de fermentação das bebidas à música constituída pelos cantos e pelo soar do tambor. Haveria finalmente as canções roubadas de inimigos, que só podiam ser extraídas por homens já maduros, os únicos que conseguiam aguentar o contato tão próximo com os espíritos dos contrários.

Vale lembrar que, de maneira similar aos guerreiros nivacle que abdicavam das expedições guerreiras para se dedicarem aos cantos e à instrução dos mais jovens, também os niniotagi eyiguayegui, quando mais velhos, viravam grandes conselheiros, sendo mais descritos no interior das tolderias. Assim como acontece com os relatos sobre as mulheres jovens e velhas, portanto, há uma diferenciação etária também entre os homens, e essas diferenças se expressam por meio de dois elementos. O primeiro é a mudança que ocorre, ao longo da vida, no "tipo" de guerra a que se dedicam jovens e velhos: com o passar do tempo, a guerra "empírica", ou seja, aquela constituída pelas expedições guerreiras, era trocada por outros atos guerreiros: os cantos realizados nas festas, as danças com os escalpos, a preparação de jovens guerreiros, as decisões tomadas pelos conselhos de anciões... O segundo é o conhecimento dos cantos, danças e pinturas corporais, distintivo de velhos e velhas. No caso dos cantos, apenas o(a)s velho(a)s podiam entoá-los, pois apenas eles tinham o corpo forte o suficiente. As pinturas corporais, que faziam das velhas "virtuoses incontestes", por sua vez, demandavam anos de prática e de experiência.

\footnotetext{
106 Segundo Sterpin (1993: 51), os Nivacle tinham uma variedade enorme de cantos, sendo aqueles roubados dos espíritos apenas uma categoria. Sugiro que os cantos Eyiguayegui poderiam ser lidos na mesma chave.

107 Pode não haver aqui uma transformação tão radical, uma vez que são fartamente documentados na América indígena os casos em que o cantor, por intermédio do corpo do guerreiro que canta, é o próprio inimigo. Seria ainda preciso verificar, no caso, a origem dos cantos entoados por cativos.

${ }^{108}$ Sterpin (1993: 51).
} 
O importante aqui é notar que as atribuições do(a)s velho(a)s são aquelas utilizadas pelas fontes na qualificação da "nobreza" eyiguayegui. O homem "nobre" por excelência, segundo seus autores, era o capitão, chefe de guerra, considerado por eles o centro das tolderias, enquanto a mulher "nobre" era a velha especialista nas artes da pintura corporal, na confecção da cerâmica e dos tecidos. Os jovens aristocratas, por sua vez, aparecem de forma menos marcada: eles são descritos como mimados, que se entregavam a brigas facilmente e que tinham todas as suas vontades atendidas pelos velhos. Mesmo as crianças por eles geradas eram geralmente criadas por seus avós ${ }^{109}$. De maneira parecida, os iiôdimiguit (cativos recém-agarrados) que, segundo Susnik (1972: 67), “ficavam nos toldos de seus captores", eram também deixados aos cuidados do(a)s velho(a)s.

Segundo Almeida Serra (1850:354),

[o]s ditos velhos e velhas, com alguns captivos da mesma idade, ou de menos conto, são os que vão buscar água, lenha, fazem o comer e pescam. Entre os Uaicurús alguns velhos, que são de origem Guanás ou Xamicocos, fazem alguma insignificante roça [...]. Os moços e mais vigorosos reservam-se para a guerra, para a qual são consultados capitães, soldados e captivos, sendo o capitão mais moço sempre o comandante da acção; assim como quando voltam é o capitão mais velho que se acha nas tolderias, aquelle a quem se dá a devida parte.

Como se depreende do relato de Almeida Serra, os senhores e as senhoras geralmente estavam, em conjunto com seus cativos, às voltas com os "serviços domésticos": eram eles que pescavam, iam buscar lenha e faziam o que comer. Esse pequeno panorama sobre as atribuições do(a)s velho(a)s (nobres e cativos) é suficiente para desmontar, de um lado, o pressuposto (fundamental na ideia de hierarquia eyiguayegui) de que os nobres não se ocupavam de tarefas domésticas, restritas a "escravos" e mulheres e, de outro, a suposição de que a relação entre "senhores" e “escravos" era fundamentada na noção de propriedade.

\subsection{Avós ou proprietários}

No capítulo anterior afirmei que a separação, primeiramente efetuada por Fortes, entre os domínios “doméstico” e "político-jurídico” estava intrinsecamente ligada às relações de gênero, ou mesmo "relações entre os sexos", visto que Fortes

\footnotetext{
${ }^{109}$ Lecznieski (2005: 75).
} 
considerava homens e mulheres como seres biologicamente dados ${ }^{110}$. Nesse sentido, mesmo Clastres supõe que as mulheres, intrinsecamente geradoras de vida, seriam avessas à guerra - voltarei a isso.

Nesse contexto, o âmbito doméstico foi por muito tempo entendido como "dado" por estar vinculado às mulheres, como se, por procriarem e amamentarem, elas vivessem naturalmente em ambientes de reprodução corporal. Esses ambientes, por sua vez, eram muitas vezes entendidos como um nível universal de socialidade, como se o doméstico fosse o mesmo em todos os lugares, sendo portanto um objeto de estudo mais próximo da psicologia, por exemplo, do que da antropologia (Carsten 2000: 17). O “político-jurídico”, por sua vez, foi a preocupação antropológica por excelência durante determinado período, preocupado em saber como se construía a sociedade como um sistema de leis e regras.

Mesmo nos estudos sobre as populações ameríndias o estudo do que costumamos definir como "doméstico" demorou a despertar o interesse de antropólogos. Segundo Overing (1999: 84), por estarem muitas vezes preocupados em “descobrir a lógica subjacente ao funcionamento da mente, do parentesco ou mesmo da criação artística”, muitos antropólogos ignoraram os afazeres cotidianos, considerandoos por demais "mundanos". A questão, segundo a antropóloga, é que os próprios interlocutores desses estudiosos não veem essas ações cotidianas como triviais: é também nesse âmbito que se convencionou chamar "doméstico" (além de domínios como o xamanismo e a caça, que geralmente prendem mais a atenção dos acadêmicos) que podemos encontrar alguns dos fundamentos das filosofias ameríndias.

Os dados trazidos pelas fontes e etnografias sobre o Eyiguayegui e Kadiwéu permitem afirmar, em consonância com Overing, que o que foi muitas vezes entendido como "doméstico" é, em diversas situações, o centro da política eyiguayegui e o local mesmo da construção das pessoas e das distinções entre elas. Quando entendemos a relação captor-cativo e os processos de criação por ela engendrados como o motor da vida social eyiguayegui (e também chaquenha), percebemos que mesmo as polarizações entre doméstico e público, feminino e masculino, são afetadas. É perceptível o fato de que homens e mulheres estão engajados na busca por crianças e cativos tanto nas expedições guerreiras quanto nas relações cotidianas, sendo impossível fazer uma

\footnotetext{
110 Refiro-me aqui à diferenciação entre "gênero" - categoria que enfatiza o caráter social da diferença entre homens e mulheres - e "sexo" - categoria que se refere a uma diferença tida, muitas vezes, como natural e inscrita num corpo fisiológico. Nesse sentido, o "gênero" ao qual me refiro não deve ser entendido como universal e sim como "uma categoria de análise relacional e dinâmica" (Mazzariello \& Bulgarelli 2015).
} 
separação entre "público/masculino" e "doméstico/feminino". Aliás, em alguns momentos essa equação parece se inverter entre os Eyiguayegui, sendo o interior das tolderias (ou o que se convencionou chamar de doméstico) o ponto central da relação com o Fora. Evidência disso é o fato de que velhos e velhas - o fundamento da aristocracia eyiguayegui - são aqueles que têm mais contato com os cativos, criando-os e construindo com eles relações de parentesco. "Senhores" e "senhoras", portanto, aparecem não no que foi considerado o "centro" da vida política (a guerra), mas ocupados com os "afazeres domésticos", entendidos muitas vezes como periféricos.

As relações do(a)s velho(a)s com o(a)s cativo(a)s, por sua vez, pareciam se diferir muito daquelas fundamentadas em um sentimento de propriedade, muitas vezes considerado a base dessa relação "de escravidão". Herbert Baldus (1975: 21), por exemplo, chegou a aventar a hipótese de que a propriedade dos "escravos" havia se desenvolvido, entre os Eyiguayegui, em conjunto com a do gado. "Pode ser", afirma o autor, "que a criação de gado, ensinando a conservar e aumentar a propriedade móvel, tenha despertado cada vez mais o desejo de aplicar também aos homens, como bens utilizáveis, a ideia econômica do capital produtivo". Também defendendo o conceito de propriedade (e, consequentemente, atribuindo aos índios uma série de pressupostos "nossos"), Santos-Granero (2009: 43) afirma que, por estarem "mais próximas aos animais do que aos humanos", as populações que eram geralmente atacadas nas buscas por cativos eram vistas como essencialmente "escravas", enquanto os cativos eram considerados, pelo menos provisoriamente, como sua propriedade pessoal, assim como o eram "suas casas, roças e roupas"111.

Ora, todas as descrições apresentadas neste trabalho contrariam a hipótese que os cativos de guerra eram entendidos como "bens utilizáveis" ou "menos-quehumanos"112: como demonstrado, não parecia haver uma noção genérica de humanidade na qual as populações estrangeiras pudessem ser situadas e, além disso, por meio dos dados disponíveis nas fontes, não há nem como saber se havia, entre aqueles índios, uma separação entre "pessoas" e "bens" ou "coisas"113, sendo portanto arriscado supor que os cativos fossem entendidos como propriedade. Ademais, até mesmo a separação entre "animais" e "humanos" entre os Eyiguayegui parecia ser, no mínimo, diferente da nossa pois, ao que tudo indica, os cavalos eram entendidos como cativos de guerra: os "senhores" dedicavam a eles os mesmos cuidados que recebiam

\footnotetext{
${ }^{111}$ Santos-Granero (2016: 39, tradução minha).

112 Expressão utilizada por Santos-Granero (2009: 43).

${ }^{113}$ Da qual temos, à luz da etnografia americanista mais recente, todas as razões para duvidar.
} 
aqueles que nós denominamos "humanos" e a captura dos cavalos também conferia prestígio ao "agarrador".

Outra evidência apontada pelas fontes e por antropólogos que supostamente provaria a existência de um sentimento de propriedade é a "venda" dos "escravos". Na maior parte das vezes, como vimos, os cativos ficavam com a família de seus captores, mas é possível que, nessa fase em que eles ainda não eram considerados parentes, pudessem ser dados a pessoas próximas ou mesmo trocados com pessoas mais distantes, como no caso tupinambá analisado por Sztutman (2012: 196). De acordo com o autor, a "economia política" envolvida nessas trocas "não dizia respeito à forma mercadoria, mas à forma pessoa": trocava-se os cativos não buscando algum acúmulo de riqueza "econômica" que pudesse resultar da transação, mas para angariar prestígio a seu dono, graças às potências trazidas pelo estrangeiro, forma completamente diversa de "riqueza".

Também como acontecia entre os Tupinambá, é possível que a invasão europeia tenha alterado o vetor da captura de cativos: se antes a intenção era trazer o outro para "dentro", ou para a constituição de uma socialidade eyiguayegui, com a intromissão dos europeus os cativos passaram a ser convertidos em mercadorias, sendo trocados com os brancos por objetos manufaturados. "A guerra passava a significar uma possibilidade de obter um grande número de cativos que poderiam ser, de sua parte, reificados e, assim, trocados com os brancos. A guerra ampliava-se passando da lógica da qualidade - o cativo a ser familiarizado - para a da quantidade - o cativo a ser trocado" (Sztutman 2012: 198).

Por fim, é possível que mesmo os poucos relatos das fontes sobre a venda de escravos sejam fruto de mal-entendidos. A estratégia de guerra em que as mulheres eram "oferecidas", por exemplo, era muitas vezes entendida pelas fontes como a "comercialização" das mulheres: Boggiani ([1895]:120) escreve, em março de 1889, que dois capitães Eyiguayegui foram ao porto Apa com a intenção de vender suas esposas, que os acompanhavam. Em nota posterior, o viajante revê sua afirmação, escrevendo que, na realidade, os Eyiguayegui apenas vendiam suas cativas, e não as mulheres "nobres". Essa dita confusão de Boggiani, por sua vez, nos diz muito sobre o próprio termo "escravidão" muitas vezes utilizado por ele e outros cronistas: fica claro no relato do italiano que ele não percebe a estratégia dos Eyiguayegui, que provavelmente foram ao porto Apa para verificar a possibilidade de atacá-lo 
futuramente ${ }^{114}$. Afirmando inicialmente que os homens estavam "comercializando" suas mulheres, ele depois muda sua versão dos fatos por considerar que apenas "escravas" podiam ser vendidas e/ou trocadas. No mais, essa pequena passagem aponta a necessidade de revisar todas as ocasiões em que os autores, de maneira muito superficial, afirmam que o(a)s "escravo(a)s" eram facilmente vendido(a)s, um dos principais argumentos utilizados por aqueles que defendem a aplicabilidade da noção de propriedade aos ameríndios.

${ }^{114}$ É interessante lembrar, aqui, que já em 1864 Visconde de Taunay havia descrito um ataque dos Eyiguayegui ao Porto Apa, demonstração de que aquele era um ponto visado pelos índios. 


\section{Cama de palha e pele de onça: algumas considerações finais}

Figura 8 - Chefe dos Guaicurús partindo para comerciar com os brancos

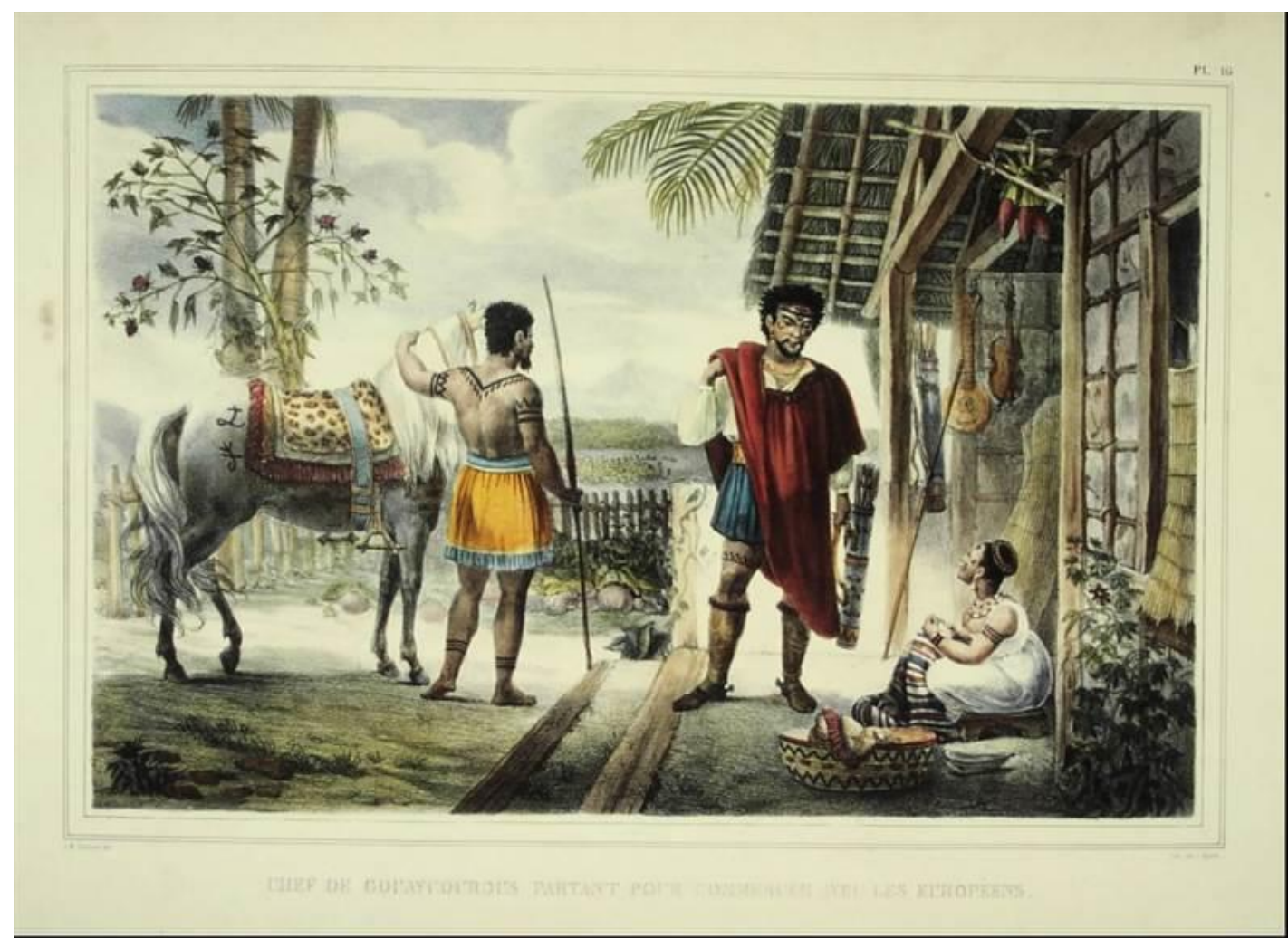

Fonte: Debret ([1834-1839]: 18)

Figura 9 - Tribu guaicurú procurando novas pastagens

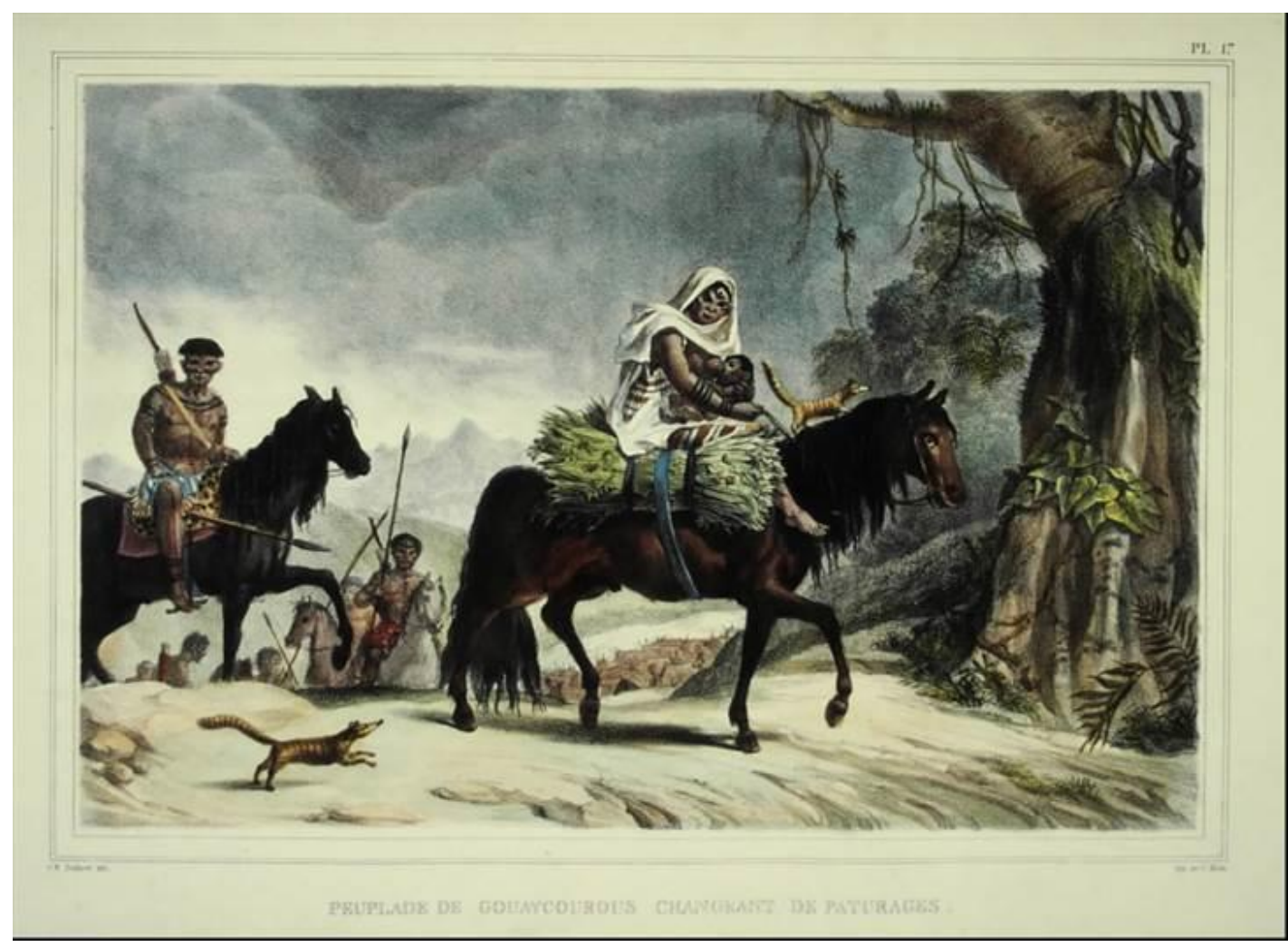

Fonte: Debret ([1834-1839]: 19) 
Figura 10 - Carga de cavalaria guaicurú

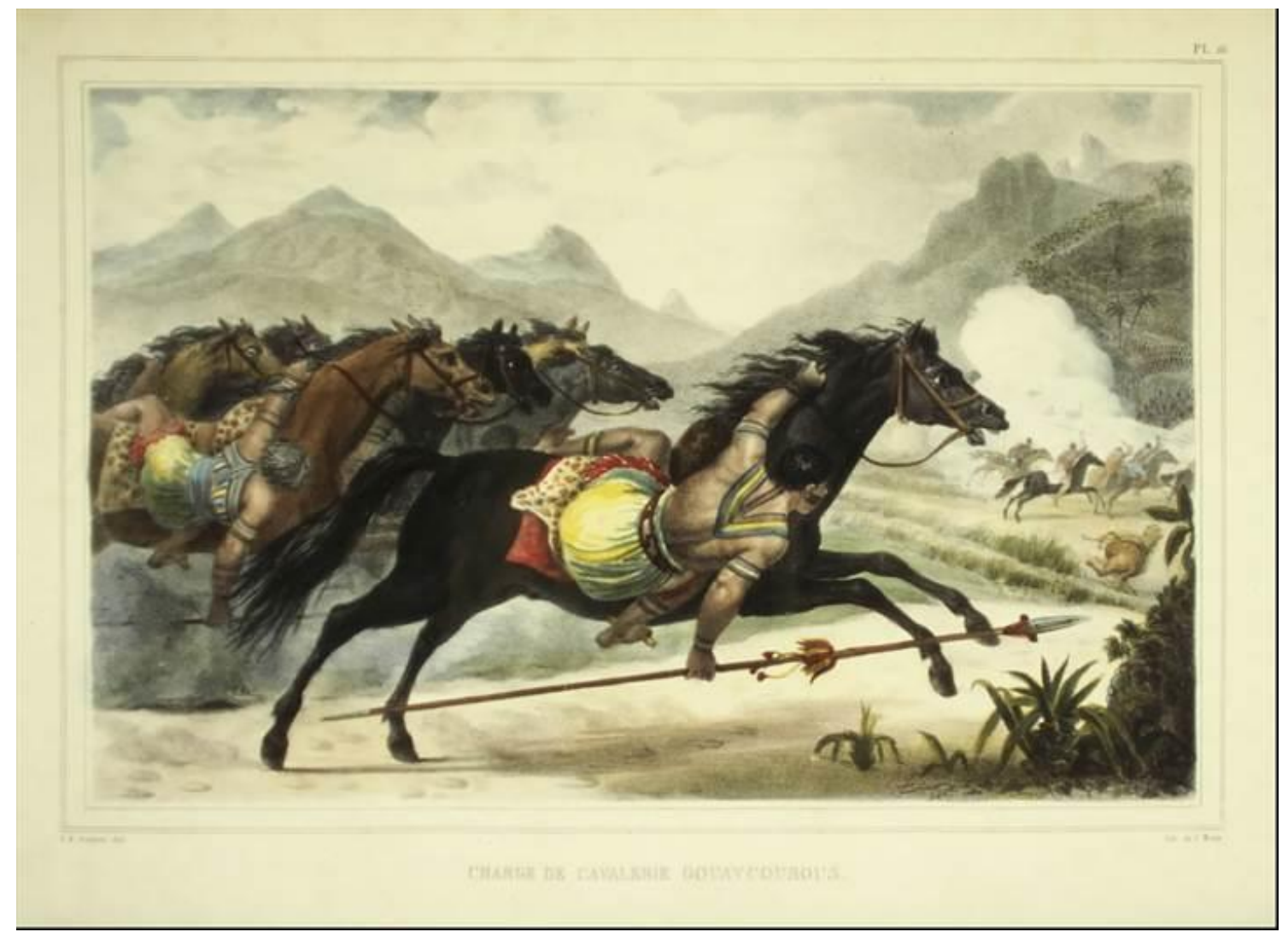

Fonte: Debret ([1834-1839]: 24)

Responsável pelas aquarelas que fizeram os "índios cavaleiros" reconhecidos mundo afora, Jean-Baptiste Debret ${ }^{1}$ parece ter conseguido transpor em imagens a inquietação característica de todos os escritos sobre os Eyiguayegui (denominados pelo autor "Guaicurus"), sejam eles parte da vasta documentação colonial chaquenha ou análises antropológicas. Nas pranchas aqui reproduzidas - as três consagradas pelo artista à população - é perceptível a sobreposição efetuada entre os costumes observados em sua curta estadia no Chaco e os pressupostos trazidos da Europa por ele.

O que mais impressionou o francês em relação aos Eyiguayegui foram seu gênio marcial e sua relação com os cavalos e, talvez por isso, os "soldados" e os equinos ocupem posições de destaque nas três telas. A primeira prancha ${ }^{2}$, denominada "Chefe dos Guaicurús partindo para comerciar com os europeus", traz três das personagens rapidamente descritas por ele em seu pequeno relato: o "nobre capitão" ao centro, um "soldado" (ou um "escravo") ao lado de um cavalo e aquela que aparenta ser uma "dona

\footnotetext{
${ }^{1}$ Jean-Baptiste Debret foi um pintor e desenhista francês que integrou, entre os anos de 1816 e 1817 , a Missão Artística Francesa ao Brasil organizada a mando do Rei Dom João VI.

${ }^{2}$ Essa primeira descrição das pranchas segue a ordem disposta no livro "Viagem pitoresca e histórica ao Brasil" ([1834]).
} 
eyiguayegui”, que está sentada tecendo (ocupação que, segundo o francês, era própria das mulheres, que mostravam grande "maestria" nos "trabalhos da agulha"3).

A prancha n. ${ }^{\circ}$, que representa a "Tribu guaicuru procurando novas pastagens", tem os guerreiros não mais no primeiro plano, mas ainda em evidência. $O$ centro da tela é a mulher eyiguayegui, que segura uma criança em seus braços e a amamenta montada em seu cavalo. Já a terceira prancha, denominada "Carga de cavalaria guaicurú", representa os "soldados" em uma expedição, exaltando a exímia maestria dos guerreiros na montaria.

Longe de pretender fazer uma análise dos elementos constituintes das aquarelas de Debret, esta pequena seção intende, à guisa de conclusão, demonstrar, por meio de suas telas, o que considero os dois maiores desafios enfrentados pela literatura sobre os povos eyiguayegui e kadiwéu: de um lado, algo tido como uma hierarquia (e que, no entanto, em tudo desafia essa qualificação) fundada em "amor” e cuidado e, de outro, uma divisão entre político e doméstico que parece não render.

A prancha n. ${ }^{\circ} 3$ (Figura 10), em que os “índios cavaleiros" são representados em sua maior vocação, a guerra, ilustra a primeira impressão que as fontes sobre os índios eyiguayegui nos deixam: descritos como índios ferozes e impiedosos, eles parecem ser equalizados a verdadeiros "domadores", tanto de cavalos quanto de gente. Escreve Debret" sobre os "Guaicurú": "são conhecidos pela sua habilidade em domar cavalos selvagens que pastam em liberdade nos campos dessa parte da América. Pegam-nos a laço, põem-lhes cabrestos, montam-nos e logo se lançam com eles pelos lagos e rios [...]”. Essa "luta desigual”, que era invariavelmente perdida pelos cavalos, parecia se aproximar bastante, segundo o que informam as fontes, com o "processo de caduveização" a que eram submetidos cativos. Tanto os "prisioneiros de guerra" quanto os cavalos eram descritos como pessoas/animais a serem amansadas por seus "senhores".

A prancha n. ${ }^{\circ} 1$ (Figura 8), por sua vez, traz em si uma ambiguidade. O homem à esquerda, parado ao lado do cavalo, pode ser interpretado tanto como um "soldado" como um cativo. A relação por vezes efetuada entre os cavalos e os cativos - ambos eram considerados "botim de guerra", traziam prestígio a seus captores, e eram "amansados" - nos permite pensar que talvez o personagem em questão fosse um nibotagi. Mas sua postura corporal e a lança por ele carregada também faz com que apareça como guerreiro. Ora, vimos que essa confusão está também presente em outras

${ }^{3} \operatorname{Debret}([1834]: 49)$.

${ }^{4}$ Debret [1834]: 49). 
fontes históricas: os limites entre um guerreiro, um "comum”, um "escravo" e mesmo um "nobre" eram sempre muito difíceis de se estabelecer, mesmo porque não havia fronteiras intransponíveis entre essas posições. Como demonstrado, era perfeitamente possível encontrar um nibotagi guerreiro, cativos podiam se tornar chefes e podem hoje agir como representantes de seus "captores". A ambiguidade presente na documentação colonial e que continua desafiando os especialistas está colocada nesta prancha de maneira clara e a ideia de "hierarquia" construída na literatura sobre os Eyiguayegui e Kadiwéu também pode ser pensada por meio desta imagem: nunca é possível afirmar com certeza quem está nas posições "inferior" e "superior" e as mesmas pessoas podem ocupar lugares diversos em diferentes contextos ou momentos de suas vidas. O que indica que nosso vocabulário precisa se ajustar de modo a abarcar maneiras outras (e não estáveis) de se pensar as distinções entre pessoas operadas pelos Eyiguayegui.

Além disso, a prancha coloca também uma tensão entre o "público" e o "doméstico". A composição da imagem faz parecer que o "chefe guaicuru” está de saída, o que é confirmado pelo título da aquarela. Segundo Debret ([1834]: 49), os capitães guaicurú tinham duas atribuições: a de chefes de guerra e a de comerciantes, sendo a principal o "comércio das diferentes espécies de animais". O chefe guaicurú está, portanto, a caminho do comércio junto com seu "soldado"/"escravo". A mulher, por sua vez, é descrita como mestra nos "trabalhos da agulha" e sua representação na aquarela é fiel àquela feita no pequeno relato do pintor. Aliás, a dona eyiguayegui é retratada de maneira curiosa: ela parece ser muito menor do que as outras duas pessoas e não usa as vestimentas geralmente descritas pelos documentos (ao contrário dos outros dois). Seu vestido e seu penteado, por exemplo, parecem legitimamente europeus, o que demonstra certa ideia de feminilidade que Debret parece ter desejado enfatizar em sua aquarela. "Senhor" e "senhora" representam, portanto, os domínios que supostamente constituiriam a vida social eyiguayegui: o público e o doméstico. Mesmo a postura corporal de homem e mulher nos remetem à afirmação de que o francês parecia estar representando, no Chaco, relações de gênero muito parecidas com as europeias.

Já a prancha n. $^{\circ}$ (Figura 9) inverte a primeira: nela, a mulher ocupa uma posição central, à frente dos guerreiros, e sua postura corporal nos remete apenas em parte a um ideal de mulher europeia. O lenço sobre sua cabeça e seu ar maternal podem ser frutos da criação do pintor, mas a obra como um todo causa espanto a olhos desavisados: o protagonismo da mulher em um ambiente externo e sua dianteira em relação aos guerreiros certamente não era de se esperar de uma mulher na primeira 
metade do século XIX ${ }^{5}$. E aí está outro possível paralelo entre as telas de Debret e as descrições históricas: ainda que elas tentem encaixar seus dados em suas concepções trazidas de além-mar, algumas de suas descrições acabam por desafiar os pressupostos de seus autores e nos apresentam outro mundo, em que operam outras distinções e modos de vida. Na prancha $n .^{\circ}$ 1, as pinturas corporais estão em evidência: elas também chocaram o artista, que não entendia o porquê da manutenção deste costume, considerando o estado "avançado" de sua civilização ${ }^{6}$. Na segunda prancha é digna de nota a cama de palha que separa a mulher do cavalo, o que não acontece com os homens que estão atrás dela; entre eles e o cavalo existe apenas a pele de onça - aquela que servia de camisa nas expedições guerreiras -, presente também na terceira aquarela. Esta diferença - que poderíamos supor mínima - entre homens e mulheres na segunda tela, que Debret fez questão de representar, pode ser lida como uma crítica eyiguayegui às maneiras como suas relações de gênero foram lidas ao longo do tempo.

Fica claro, pela exposição realizada ao longo deste trabalho, que os critérios utilizados por autores de fontes históricas e antropólogos até hoje para entender as relações de gênero eyiguayegui não servem àquele contexto. Oposições entre natureza e sociedade, doméstico e público, guerra e arte não nos ajudam a tornar as distinções entre homens e mulheres eyiguayegui / kadiwéu inteligíveis. O que a cama de palha e a pele de onça parecem nos mostrar é que suas diferenciações de gênero devem ser procuradas em outros elementos, que poderíamos considerar mais sutis, mas que parecem apontar para direções ainda não exploradas. A cama de palha colocada entre a mulher e o cavalo é entendida por Sánchez-Labrador ${ }^{7}$ como uma forma de dar comodidade à mulher, mas talvez ela possa ser lida também como uma maneira de evitar o contato em demasia da "dona" com o cavalo: vimos que as mulheres (principalmente aquelas em período de amamentação, como a representada pela aquarela de Debret) precisavam controlar seu contato com animais muito mais do que os homens, que usavam camisas de pele de onça e as colocavam entre eles e os cavalos.

\footnotetext{
${ }^{5}$ Note-se, no entanto, que é comum, entre muitas populações ameríndias, que as mulheres caminhem na frente em deslocamentos e expedições.

${ }^{6}$ Debret ([1834]: 50).

7 Sánchez-Labrador ([1770-1776], v. II: 27) tem uma longa descrição da cela utilizada pelas "donas eyiguayegui”: "La silla es pobre pero acomodada. Sobre el lomo del caballo pone una especie de paja seca, parecida en lo suave al heno, pero más larga. Hallase en casi todos los sitios de su parada; y si no, la cortan en donde la hallan, parando la comitiva y llevando de prevención para remudarla. Sobre la paja asientan unos bastos hechos de juncos suaves, que, a excepción de ser más cortos, parecen enjalma. Cubren ésta con una piel de ciervo bien sobada, larga y doblada dos ó más veces. [...] Doblan sobre los bastos lo que cuelga, y queda el caparazón formado, sobre el cual se pone la mujer dejando caer las piernas por sobre las cabezas de la enjalma hacie el cuello del caballo. Así va sentada y estirada”.
} 
Quando afirmo que, no contexto eyiguayegui, a guerra não deve ser entendida como uma atribuição masculina e que a arte não se restringe às mulheres; ou mesmo quando demonstro, por meio dos dados, que homens e mulheres tinham atribuições tanto no âmbito "doméstico" quanto "público", não quero dizer que não existam, na filosofia eyiguayegui/kadiwéu, diferenciações de gênero. $O$ meu ponto é que essas distinções não devem ser pensadas por meio da polarização entre natureza e cultura, que parece originar aquelas outras duas que foram discutidas ao longo do trabalho.

É interessante notar que a superioridade das mulheres eyiguayegui é um tema comum na literatura que se debruça sobre esses índios. Herbert Baldus (1975:34), por exemplo, lista oito elementos que comprovam sua supremacia sobre os homens: de acordo com o antropólogo, a liberdade das capitãs, as homenagens recebidas pelas mães dos guerreiros, a importância da festa da moça e a uxorilocalidade, discutidas ao longo do trabalho, seriam suficientes para demonstrar a "acentuação da importância do sexo feminino" naquela sociedade. Ademais, o fato de as mulheres poderem controlar a reprodução, tendo um número limitado de filhos, asseguraria, segundo o autor, sua independência, marca de sua grande autoridade. De forma parecida, o francês LéviStrauss (1996:188) também exalta a "independência e autoridade das mulheres de alta estirpe" eyiguayegui. Quando procuramos saber de onde vem a dita "superioridade" feminina segundo a visão destes antropólogos, porém, nos deparamos com a velha afirmação (nem sempre declarada abertamente) de que as mulheres estariam mais para o lado da natureza.

O antropólogo que aplica esse modelo de maneira mais clara é Pierre Clastres. Também afirmando a superioridade das mulheres - não apenas entre aqueles povos denominados por ele "Guaicurú", mas em todas as sociedades ameríndias -, Clastres coloca em suas mãos o controle do processo reprodutivo. Segundo o autor, os homens, nas "sociedades primitivas", são definidos pela "condição" de sua sociedade: sendo a sociedade primitiva contra o Estado e para-a-guerra, os homens são também, de acordo com o francês, seres-para-a-guerra e para-a-morte. "Há, portanto, pela mediação da guerra, uma relação íntima, uma proximidade essencial entre masculinidade e morte" ${ }^{8}$. As mulheres, em contraponto, teriam como "propriedade essencial" a "reprodução biológica", havendo, portanto, "uma proximidade imediata entre vida e feminilidade". $\mathrm{O}$ argumento de Clastres, aparentemente à sua revelia, leva-o a afirmar que as mulheres

\footnotetext{
${ }^{8}$ Clastres (2004: 290).
} 
são (naturalmente) contra a guerra ${ }^{9}$, o que, como vimos, não se aplica ao caso eyiguayegui, e que enquanto o ser dos homens é definido pelo social (a guerra e a morte), o ser das mulheres é biológico e, portanto, universal. Uma decorrência de seu argumento é a de que não há grandes diferenças entre as mulheres de "sociedades primitivas" e das sociedades "pós-malencontro": todas as mulheres têm a mesma essência, são todas dotadas de um mesmo corpo. Ainda de acordo com o etnólogo, a relação entre mulheres e homens nas Américas seria mediada por "seu vínculo respectivo com a vida e a morte sociais e biológicas" ${ }^{10}$. No caso eyiguayegui, porém, haveria um desequilíbrio - já detectado pelas fontes históricas e por Lévi-Strauss -, em que as mulheres se recusariam a cumprir seu papel e se tornariam, também "seres-paraa-morte”, abortando suas gestações.

Lévi-Strauss acaba fazendo um movimento parecido, embora mais sutil. De acordo com o autor, ao realizarem as pinturas corporais - que conferiam "humanidade" aos nobres e negavam o corpo "dado" pela natureza - e se negarem a deixar suas crianças nascerem, as "donas" teriam o importante papel de efetuar a passagem da natureza para a cultura. Segundo o etnólogo, os Eyiguayegui eram uma sociedade que negava totalmente a natureza, e as mulheres eram os sujeitos ativos dessa negação, de onde se originaria sua grande autoridade.

É perceptível que tanto Baldus quanto Lévi-Strauss e Clastres fundamentam a ideia de "superioridade" das mulheres eyiguayegui no controle de natalidade por elas praticado, ou seja, em sua capacidade de reger o substrato natural da sociedade: "as mulheres trazem ao mundo os filhos", já nos lembrava Clastres ${ }^{11}$. Esse "poder" das mulheres, porém, acabaria por aprisioná-las: é como se elas tivessem que escolher entre exercer sua liberdade e não ter filhos, ou aceitar sua sina de mãe em prol da sobrevivência de sua sociedade. Clastres chega até mesmo a opor o "desejo social da sociedade de levar a guerra e a morte alhures" e o "desejo individual das mulheres de não ter filhos" ${ }^{2}$. O erro das mulheres eyiguayegui seria, nesse sentido, o de resolver mal esse impasse e querer sair de sua condição natural - a de mães -, compartilhando a paixão guerreira de seus maridos. Lévi-Strauss também parece responsabilizar as mulheres pelo fim iminente de sua sociedade, ainda que seja mais otimista. Segundo o autor, em contrapeso à sua relutância pela procriação, que tornaria sua sociedade

\footnotetext{
${ }^{9} \mathrm{O}$ que não deixa de ser curioso, visto que sua intenção, ao final de $O$ infortúnio do guerreiro selvagem (1977) - ensaio dedicado às "sociedades de guerreiros" chaquenhas -, é exatamente oposta: o autor pretende de demonstrar a intencionalidade política das mulheres eyiguayegui.

${ }^{10}$ Clastres (2004:287).

11 Clastres (2004: 290)

12 Clastres (2004: 273-4).
} 
impossível, as mulheres desenvolveriam sua arte que, ao equilibrar elementos assimétricos e simétricos, acabaria por "resolver", pelo menos no plano das artes, "suas contradições"13.

Temos aqui um caso em que a suposta "superioridade" das mulheres acaba por fazê-las prisioneiras: de acordo com essa teoria, ao escolherem engravidar quando estivessem mais velhas, as mulheres eyiguayegui estariam colocando em risco sua própria sociedade. Mas, por mais interessante que essa hipótese seja, ela não consegue explicar a persistência dessa sociedade que, mesmo praticando um "racismo às avessas" em seu afã de incorporar estrangeiros ${ }^{14}$, continua existindo. $O$ fato é que, como demonstrado ao longo deste trabalho, é impossível determinar, a priori, a "essência" das mulheres ou, nas palavras de Clastres ${ }^{15}$, aquilo "que define integralmente seu ser", assim como é impossível realizar essa mesma operação em relação aos homens. No mais, a polaridade entre homens como seres-para-a-morte e mulheres como seres-paraa-vida construída por Clastres encontra outro obstáculo quando consideramos que, de acordo com as concepções ameríndias de reprodução e produção do corpo e da pessoa, as mulheres nem sempre participam da concepção de crianças. Em muitos contextos etnográficos, elas nem chegam a participar do crescimento uterino do feto, que se desenvolve somente a partir do sêmem do(s) homem(s). Em outros, homens e mulheres participam desse desenvolvimento, e há casos em que apenas a mulher contribui para que a criança se desenvolva na gestação. Depois do nascimento da criança, não apenas a mulher contribui para seu crescimento, mas o corpo do novo ser é fabricado por meio da troca de substâncias de ambos os pais, avós e irmãos. É impossível, nesse sentido, delimitar um campo do doméstico, da reprodução biológica e das mulheres, visto que a construção do corpo atravessa todos os âmbitos da vida social, não apenas nas relações familiares, como em rituais de iniciação, entre outros.

No que tange às mulheres eyiguayegui, sugiro que o fato de as mulheres realizarem abortos e, muitas vezes, não parirem nenhuma criança, não significa que elas abdicassem do papel de "seres-para-a-vida" (que era compartilhado também pelos homens): pelo que apresentei, os abortos eram uma forma de preparação do corpo para a guerra, que deve ser enxergada aqui como geração de vida em vários sentidos. Era na guerra que os Eyiguayegui estabeleciam relações com as populações vizinhas, casandose com e adotando "inimigos e estranhos", nas palavras de Lévi-Strauss. Ao contrário

\footnotetext{
${ }^{13}$ Lévi-Strauss (1996: 209-10).

${ }^{14}$ Lévi-Strauss (1996: 184).

${ }^{15}$ Clastres (2004: 290).
} 
do que afirmava Clastres, nesse sentido, sugiro que mulheres e homens eyiguayegui podem ser entendidos como seres-para-a-vida, que viviam para os momentos em que suas tolderias recebiam os estrangeiros. $\mathrm{O}$ "racismo às avessas" daqueles nobres índios, assim, não era a sentença de morte dos Eyiguayegui, como escreveu Lévi-Strauss, e sim sua condição de vida.

É perceptível que a ideia de "superioridade" atrelada às mulheres na literatura especializada acabou por aprisioná-las. Operar com noções de "superioridade" e "inferioridade", no que se refere tanto às relações entre niniotagi e nibotagi quanto às relações de gênero, não nos faz avançar no conhecimento acerca das distinções eyiguayegui, cuja lógica é evidentemente outra. Para avançar nos estudos acerca dos elementos de diferenciação entre pessoas que se multiplicam na filosofia eyiguayegui é necessário revisar todas as afirmações que as construíram ao longo dos séculos, partindo do pressuposto de que não sabemos, afinal, o que é uma mulher ou um homem eyiguayegui ${ }^{16}$, um nibotagi ou um niniotagi.

Nesse sentido, essa dissertação procura, por meio dos escritos dos próprios colonos, demonstrar como os conceitos de hierarquia, escravidão e servidão fazem parte de um aparato conceitual desenvolvido em um contexto colonialista que faz andar juntas certas noções - como as de sociedade, trabalho e relações de gênero - que não são mais produtivas em análises antropológicas. $\mathrm{O}$ trabalho de decompor esse aparato, por sua vez, permitiu enxergar, no lugar do que geralmente se denomina "hierarquia kadiwéu", processos de aparentamento em relação aos cativos ou de formas de troca referentes à afinidade em relação a outras populações, o que fez com que o diálogo com outros contextos ameríndios, também permeados pela produção de afinidade e consanguinidade, se tornasse inevitável. No mais, a pesquisa procura contribuir colocando em evidência algumas pistas trazidas pelas fontes coloniais e análises antropológicas - como aquelas acerca da construção do corpo e das atribuições - que, quando comparadas às descrições coloniais de populações tributárias, chefias hereditárias e "camadas" inteiras formadas por "escravos", são consideradas menores e insignificantes, mas se mostram imprescindíveis para delinear uma nova maneira de apreender os modos de relação e de distinção de pessoas operados pelos Eyiguayegui/Kadiwéu.

\footnotetext{
${ }^{16}$ Não sabemos, inclusive, se "homem" e "mulher" são categorias estanques: a possibilidade de pessoas consideradas pelos autores das fontes "homens" poderem se transformar em mulheres (como é o caso dos cudinas) deixa essa questão em aberto.
} 


\section{Nota metodológica}

Como a leitura das páginas anteriores demonstra, este não é um trabalho de cunho historiográfico, mesmo que grande parte dos dados analisados provenham de documentos datados desde o século XVI. Ainda assim, a origem dessas descrições não foi ignorada: desde o começo da pesquisa ${ }^{17}$ foram objeto de detida atenção tanto $o$ contexto que levou cada um dos viajantes, missionários e oficiais ao Chaco quanto as intenções que se pode ver ou entrever em cada um de seus relatos. Em minha análise, por exemplo, a intenção de Sánchez-Labrador de evidenciar que, por mais bárbaros que fossem, os índios chaquenhos demonstravam grande interesse na catequização e na aproximação de Deus é sempre levada em conta, bem como o esforço de militares como Rodrigues do Prado e Almeida Serra para provar a incapacidade de aldeamento e sedentarização daqueles indígenas, que seriam essencialmente instáveis. A análise das crônicas aqui apresentadas, portanto, levou em consideração as "marcas do pertencimento dos autores destas descrições a um tempo, culturas e cosmologias específicos, além das intenções [...] que direciona[va $] \mathrm{m}$ os relatos"18, de modo a qualificar os dados etnográficos e os termos da descrição ${ }^{19}$.

No entanto, essa relação entre o contexto histórico e as obras analisadas não está no primeiro plano da pesquisa, que se preocupou mais em tentar “[ [...] reconstituir a grade de deciframento" que os autores das fontes e antropólogos aplicaram a todas as "circunstâncias que de algum modo a ele[s] se impu[seram]" (Goldman 1994:13). A intenção do presente trabalho foi a de mergulhar nas linhas de argumentação que levaram autores de documentos e análises antropológicas a definirem as relações sociais eyiguayegui como "hierárquicas" e a qualificar segundo pressupostos universalistas as posições de homens e mulheres.

A análise das fontes históricas que fundamentou parte da presente pesquisa, nesse sentido, se distinguiu tanto da leitura contextualizante da historiografia clássica

\footnotetext{
${ }_{17}$ A pesquisa que embasa esta dissertação começou na Iniciação Científica (2010-2012; bolsa PIBICUSP), com o título de "Perspectivas etnográficas acerca da hierarquia entre os Kadiwéu", desenvolvida ao longo de dois anos também sob orientação da $\operatorname{Prof}^{\mathrm{a}} \operatorname{Dr}^{\mathrm{a}}$ Beatriz Perrone-Moisés.

${ }^{18}$ Sztutman (2005:87).

${ }_{19}$ Durante a pesquisa, foi necessário atentar para o fato de que, assim como as fontes históricas sobre os Tupi analisadas por Sztutman, os autores dos documentos chaquenhos também “[...] não foram ao campo munidos de questões antropológicas, tampouco com a ideia de que é preciso desfazer-se de sua bagagem cultural para compreender uma outra sociedade. No que se refere à sua escrita, é possível notar uma oscilação constante entre uma impossibilidade de ver de fora de esquemas ontológicos dados e essa participação inevitável em um projeto expansionista, que é tanto do cristianismo (monoteísmo) como dos Estado-nação que começavam a se formar - ambos seduzidos por essa estranha gramática da Unidade” (Sztutman 2012: 124).
} 
quanto de alguns ensinamentos deixados por Florestan Fernandes, referência no estudo de fontes históricas sobre populações indígenas. Preocupado com a veracidade e a validade científica dos dados presentes nos documentos, o autor afirmava que o centro do trabalho etnológico na leitura da documentação histórica estaria no " $[\ldots]$ exame crítico do conteúdo etnográfico ou sociológico das fontes"20. De acordo com Fernandes, o etnólogo não deve operar com "a totalidade dos textos", pois interessamlhe apenas aqueles "que contêm dados e informações suscetíveis de aproveitamento científico”. Em direção contrária a Fernandes, deixei de enxergar as obras analisadas como simples depositários de dados etnográficos, interessando-me também pelas intuições que fundamentavam as descrições e análises de viajantes, cronistas, missionários e exploradores. De maneira similar, a forma de apresentação dos dados e o encadeamento realizado entre eles também ensinaram muito sobre a construção dos conceitos de hierarquia e relação entre gêneros na região chaquenha.

Compartilho, portanto, apenas em parte da preocupação de Fernandes acerca da consistência das informações contidas nos documentos históricos, uma das evidências de veracidade dos dados, segundo ele. De um lado, concordo com o autor quando afirma que a reincidência da descrição de determinados ornamentos, táticas guerreiras, jogos, festas, entre outros, é um dado extremamente importante para o curso da pesquisa. Foi a repetição, em diversos relatos, da descrição do uso das mulheres como "iscas" em expedições guerreiras, por exemplo, que me levou a perceber o papel central das mulheres na guerra. Por outro lado, considero que descrições isoladas, ou realizadas por apenas um autor, não devem ser excluídas ou consideradas sem validade científica: elas revelaram, muitas vezes, uma linha de argumentação que permitiu encontrar, nas entrelinhas dos relatos, o que aqui chamo de distinções eyiguayegui. Além disso, se levássemos os ensinamentos de Fernandes às últimas consequências e só considerássemos verossímeis dados presentes em duas ou mais fontes, acabaríamos por descartar muitas das descrições feitas pelo missionário Sánchez-Labrador, que são únicas, não porque ele tenha inventado tais dados, mas porque sua convivência com os Eyiguayegui foi muito mais duradoura do que a de maior partes dos autores.

A pesquisa se desenvolveu, então, por meio da execução de cruzamentos não apenas entre dados separados de seus contextos de apresentação (como fazia F. Fernandes), mas também dos temas levantados pelas fontes ${ }^{21}$, organizados em tabelas.

\footnotetext{
${ }^{20}$ Fernandes (2009: 216).

${ }^{21}$ É comum encontrar nas fontes chaquenhas seções que tem como ponto central, por exemplo, a liberdade das mulheres e dos "escravos"; a inconstância eyiguayegui; a falta de leis e de autoridade dos capitães e, como não podia deixar de ser, a guerra.
} 
Analisando os relatos, percebi por exemplo que o tema da guerra se cruzava com outros temas e/ou elementos, como a constituição da nobreza e da "estratificação social" e o papel das mulheres e dos homens jovens. Quando tentei isolar, em duas tabelas distintas, as descrições sobre os capitães de um lado e sobre seus cativos de outro, percebi que era uma proposta quase impraticável, uma vez que os nobres só eram definidos em relação a seus cativos, e para isso eu teria que, literalmente, separar frases ao meio. Essa oposição realizada pelas fontes, que foi transplantada para as tabelas, acabou por guiar o caminho da pesquisa: as relações efetuadas por elas (como aquela entre "trabalho" e inferioridade) puderam ser encontradas também nas análises antropológicas mais recentes sobre os Kadiwéu, revelando certas linhas de continuidade na literatura especializada.

O interesse nesses velhos relatos se deve, portanto, tanto à riqueza dos dados que contêm como ao reconhecimento da atualidade virtual e potencial dos pensamentos contidos nessas obras, constantemente reativados no presente e basilares para muitas descrições e caracterizações da política eyiguayegui e kadiwéu. Nesse sentido, o trabalho teve a intenção de realizar uma apresentação "geográfica" das reflexões contidas nas fontes e nas produções antropológicas, considerando-as como paisagens que são contemporâneas e abandonando a ilusão cronológica de sucessão de doutrinas (Goldman 1994:24; Châtelet 1974). Revisitar as descrições dos antigos Eyiguayegui permitiu iluminar algumas intuições que podem nos tirar dos impasses contemporâneos $^{22}$ produzidos em grande parte pela persistência do conceito de hierarquia, além de reabrir debates que, ainda que fundamentem grande parte da literatura atual, seguiam hermeticamente fechados.

Considerar fontes históricas e etnografias como "contemporâneas" entre si acabou por fazer com que os dados presentes tanto em umas quanto em outras pudessem ser lidos de maneira semelhante. De um lado, confiei nas intuições dos autores das fontes mais do que geralmente se confia (pelo menos entre antropólogos); de outro, desconfiei de uma "autoridade etnográfica" ${ }^{23}$ que supostamente confere aos antropólogos maior domínio ou conhecimento sobre determinadas relações ou "sociedades". Este movimento acabou por me fazer comparar, no mesmo nível, dados trazidos por fontes do passado e por etnografias contemporâneas. Aqui esbarro em mais uma questão importante: em que medida as informações trazidas pela

\footnotetext{
22 A inspiração em intuições consideradas muitas vezes ultrapassadas é uma proposta de Goldman (1994:32), que acabou por influenciar minha leitura das fontes históricas.

${ }^{23} \mathrm{O}$ termo é de James Clifford (2002).
} 
documentação colonial pode ser lida à luz da literatura atual sobre os povos ameríndios?

O trabalho partiu do pressuposto de que, assim como olhar para o passado ajuda a compreender as populações presentes (como afirma a máxima da historiografia), também o conhecimento etnológico atual pode contribuir para a decifração de "certos aspectos dos povos antigos" 24. Esta parece ser, aliás, a particularidade da leitura etnológica das fontes: as reflexões atuais sobre os povos ameríndios acabam por iluminar certos elementos "obscurecidos pelo olhar contextualizado das fontes" efetuado pela historiografia ${ }^{25}$. As descrições da festa da moça, praticamente inexistentes nas fontes e muito presentes nas etnografias, são um exemplo disso: por meio delas foi possível traçar um paralelo entre as "festas de iniciação" feminina e masculina (estas últimas sim descritas por Sánchez-Labrador), que se iluminam mutuamente. O método de fazer dialogar documentos históricos com a literatura contemporânea teve aqui o objetivo de produzir uma reflexão acerca de temas e leituras compartilhados. Mas é preciso salientar que a comparação efetuada durante a pesquisa entre fontes e etnografias não se fundamenta na suposição de que há uma sucessão natural entre "os Eyiguayegui" e "os Kadiwéu”, ou uma continuidade linear/cronológica entre passado e presente. O diálogo aqui realizado só foi possível na medida em que se construiu uma base de comparação entre estes dois corpus: foi por meio do questionamento dos modos de apreensão das diferenciações eyiguayegui e kadiwéu que viajantes, missionários, exploradores e antropólogos puderam entrar em contato nesta pesquisa.

Por fim, o trabalho efetuou também o esforço de tecer pontes entre a etnologia brasileira e o campo de estudos que se convencionou chamar de Antropologia do Chaco, cujo diálogo ainda é incipiente. As poucas trocas entre essas diferentes tradições parecem ser causadas, em grande parte, pelo fato de a chamada Antropologia do Chaco ter estado por muito tempo isolada do corpo de produções etnográficas sul-americanas. Segundo Florência Tola (2013:16), desde o seu início - quando europeus como Erlan Nordenskiöld, Rafael Karsten e Eric van Rosen, além do suíço-argentino Alfred Métraux, cuja obra é entendida como o pontapé inicial para o avanço das pesquisas sobre o Chaco e a reinvenção da etnografia da região - até recentemente, os estudos

\footnotetext{
24. Sztutman (2012: 144).

25 Sztutman (2012: 145). Para uma discussão aprofundada sobre a leitura etnológica de fontes históricas, ver Sztutman (2012); Perrone-Moisés \& Sztutman (2010); Fausto (1992).
} 
sobre o Chaco raramente dialogam entre si e com as demais pesquisas realizadas na América do Sul26.

A Antropologia do Chaco, por ter estado por muito tempo isolada do restante da reflexão a respeito de povos indígenas sul-americanos, é relativamente desconhecida no Brasil. "O Chaco não existe" do ponto de vista dos grandes modelos teóricos e historiográficos sul-americanos, afirma Kathleen Lowrey (2006:25), que defende a ideia de que, mesmo sendo reconhecida como uma área marginal na produção de conceitos antropológicos acerca das sociedades ameríndias, o Gran Chaco tem uma grande vantagem: “[ ...] su meticulosidad etnográfica y su potencial historiográfico" 27 . Tendo à sua disposição um significativo acervo de documentos históricos e um importante corpus etnográfico sobre as populações chaquenhas atuais, a Antropologia do Chaco estaria predisposta, portanto, a uma maior margem de "criatividade teórica" 28.

$\mathrm{O}$ isolamento a que se referem Tola e Lowrey é facilmente percebido quando estudamos os habitantes da R.I. Kadiwéu. Nos principais estudos acerca desses grupos $^{29}$ - boa parte realizada no âmbito de programas de pós-graduação brasileiros as relações desses coletivos com outros grupos do Chaco, e mesmo com seu próprio passado chaquenho, não são particularmente enfocadas. Por outro lado, a profícua Antropologia do Chaco desenvolvida sobretudo na Argentina e fundamentando-se na literatura colonial e em monografias mais recentes, debruçada sobre temas como o xamanismo, a etnoastronomia e processos de definição étnica, pouco tem a dizer a respeito dos Kadiwéu ${ }^{30}$. Dos dois lados do Rio Paraguai, as duas "frentes" de pesquisa caminham em paralelo, fazendo com que o conhecimento acerca dos povos indígenas do Chaco seja prejudicado pela delimitação de fronteiras entre os povos, tomados isoladamente, e entre os pesquisadores. Nesse sentido, o trabalho se desenvolveu com a intenção de avolumar os diálogos entre os escritos sobre os Kadiwéu e sobre o Chaco ${ }^{31}$, comumente atravessados por temáticas que são comuns a diversas populações ameríndias, tanto do presente quanto do passado.

\footnotetext{
${ }^{26}$ Para um histórico mais detalhado do campo de estudos que se convencionou chamar Antropologia do Chaco, ver Lowrey (2006); Gordillo (2006); Combès, Lowrey e Villar (2009) e Tola (2013).

27 Lowrey (2006:30).

28 Tola (2013:23) e Combès, Lowrey \& Villar (2009:70-76),

29 Ver Pechincha (1994); Siqueira Jr. (1993); Lecznieski (2005); José da Silva (2011); José da Silva e Kok (2014).

${ }^{30}$ Combès, Villar e Lowrey (2009:74).

31 Essa proposta, que guiou grande parte da pesquisa, se conecta ao esforço atual de diversos "chacólogos" que têm se empenhado em fazer conversar os estudos sobre o Gran Chaco com aqueles sobre as perspectivas e corpos ameríndios, desenvolvidos em sua maior parte no Brasil (Combès, Villar \& Lowrey 2009).
} 


\section{Fontes e referências bibliográficas}

\section{Fontes históricas}

AGUIRRE, D. Juan Francisco. [1793] 1898. "Etnografía del Chaco. Manuscrito del Capitán de Fragata D. Juan Francisco Aguirre" in Boletin del Instituto Geográfico Argentino, tomo XIX. Buenos Aires, Local del Instituto, pp. 465-511.

ALMEIDA SERRA, Ricardo Franco de. 1844. "Extracto da Descripção da Provincia de Mato-Grosso, feita em 1797, feita por Ricardo Franco de Almeida Serra, SargentoMór de Engenheiros" in Revista do Instituto Histórico e Geográfico do Brasil, v. 6. Rio de Janeiro, pp. $156-196$.

1845. "Parecer sobre o aldeamento dos índios Uiacurús e Guanás com a descripção dos seus usos, religião, estabilidade e costumes" in Revista do Instituto Histórico e Geográfico Brasileiro, v.7, pp. 196-208.

1850. "Continuação do parecer sobre os índios Uaicurús e Guanás”. Revista do Instituto Histórico e Geográfico Brasileiro, v. 13, pp. 348-395.

AZARA, Félix. [1809] 1923. Viajes por la América Meridional, v. I. Madrid: Calpe.

BOGGIANI, Guido. [1895] 1975. Os caduveos. Belo Horizonte, Editora Itatiaia.

CABEZA DE VACA, Álvar Nuñes. [1555] 1987. Naufrágios e Comentários. Porto Alegre: L\&PM Editores.

CACERES, Luiz d'Albuquerque de Mello Pereira e. 1865. "Exploração do Rio Paraguay e Primeiras Práticas com os índios Guaikurús" in Revista Trimensal do Instituto Histórico Geográfico e Ethnographico do Brasil, tomo XXVIII, pp. 70-117.

CASTElnaU, Francis de. [1850] 1949. Expedição às Regiões Centrais da América do Sul. São Paulo: Coleção Brasiliana.

DEBRET, Jean Baptiste. 1834-1839. Voyage pittoresque et historique au Brésil: séjour d'um artiste français au Brésil, depuis 1816 jusqu'en 1831. Paris; Firmin Didot.

EdUSP, $2 \mathrm{v}$. . [1834] 1972. Viagem pitoresca e histórica ao Brasil. São Paulo:

DOBRIZHOFFER, Martín. [1784] 1970. Historia de los Abipones. Santa Fe: Universidad Nacional del Litoral.

LOZANO, Pedro. 1873. Historia de la conquista del Paraguay, Rio de la Plata y Tucuman. Buenos Aires: Casa Editora Imprenta Popular.

PAUCKE, Florián. [1743-1767]1942-1944. Hacia allá y para acá. Una estada entre los mocovíes. Tucumán/Buenos Aires: Universidad Nacional de Tucumán/Institución Cultural Argentino-Germana.

RIVASSEAU, Emilio. [1936] 1941. A vida dos Indios Guaycurús: Quinze dias nas suas aldeias. São Paulo: Companhia Editora Nacional.

RODRIGUES DO PRADO, Francisco. 1795. "História dos Índios Cavalleiros ou da Nação Guaycurú", in Revista do Instituto Hisórico e Geográfico Brasileiro, v. I, pp. 25-57.

SÁNCHEZ-LABRADOR, José. [1770-1776] 1910. El Paraguay Católico. Buenos Aires, $2 \mathrm{v}$. 
SCHMIDEL, Ulrich. [1602] 1986. Relatos de la conquista del Rio de la Plata y Paraguay 1534-1554. Madrid: Alianza Editorial.

TAUNAY, Alfredo d'Escrangole. 1931. Entre os nossos indios: entre Chanés, Terenas, Kinikinaus, Guanás, Laianas, Guatós, Guaycurús, Caingangs. São Paulo: Editora Melhoramentos.

1874. "De Ierecê a Guaná:" in DINARTE, Silvio

(org.). Histórias Brazileiras org. Rio de Janeiro, pp. 8-62.

\section{Bibliografia geral}

ANDRELLO, Geraldo. 2004. Iarauetê: transformações sociais e cotidianas no rio Uaupés (alto rio Negro, Amazonas). Campinas: Unicamp (Tese de Doutorado em Antropologia Social).

BALDUS, Herbert. 1975. "Introdução" in Os Caduveos. Belo Horizonte, Itatiaia, pp. 1146.

BALDUS, Herbert e WILLEMS, Edward. 1939. Dicionário de Etnologia e Sociologia. São Paulo: Biblioteca Pedagógica Brasileira.

BELAUNDE, Luisa Elvira. 2006. "A força dos pensamentos, o fedor do sangue: hematologia e gênero na Amazônia" in Revista de Antropologia v. 49, pp. $205-243$.

BOAS, Franz. 1952. Contrbutions to the ethnology of Kwakiutl. New York: Columbia University Press.

BONILLA, Oiara. 2005. "O bom patrão e o inimigo voraz: predação e comércio na cosmologia paumari” in Mana v. 11, n. 1, pp. 41-66.

BRAUNSTEIN, José. 1983. Algunos rasgos de la organización social de los indígenas del Gran Chaco. Trabajos de Etnologia 2. Buenos Aires: Universidad de Buenos Aires.

BUENO. 1987. "Introdução: Cabeza de Vaca e a utopia plausível" in CABEZA DE VACA, Álvar Nuñes. Naufrágios e Comentários. Porto Alegre: L\&PM Editores.

CARDOSO DE OLIVEIRA, Roberto. 1980. "Prefácio" in Hierarquia e simbiose: relações intertribais no Brasil. Brasília: HUCITEC, pp. VII-XIII.

1983. Enigmas e soluções: exercícios de etnologia

e de crítica. Rio de Janeiro: Tempo Brasileiro; Fortaleza: Edições Universidade Federal do Ceará. "Matrimônio e solidariedade tribal terêna", pp. 31-53; "Dualismo terêna", pp. 76-83.

CARNEIRO DA CUNHA, Manuela. 1978. Os mortos e os outros. Uma análise do sistema funerário e da noção de pessoa entre os índios Krahó. São Paulo: Hucitec.

CARNEIRO DA CUNHA, Manuela (org). 1992 História dos índios no Brasil. São Paulo: Companhia das Letras/Secretaria Municipal de Cultura/FAPESP.

CARNEIRO DA CUNHA, Manuela \& VIVEIROS DE CASTRO, Eduardo. 2009. "Vingança e temporalidade: os Tupinambá" in M. Carneiro da Cunha, Cultura com aspas e outros ensaios. São Paulo: Cosac Naify, pp. 77-99.

CARSTEN, Janet. 2000. "Introduction: cultures of relatedness" in J. Carsten (org.) Cultures of relatedness. New approaches to the study of kinship. Cambridge: Cambridge University Press, pp. 1-37. 
CARVALHO, Silvia Mônica. 2002. "Chaco: encruzilhada de povos e 'melting-pot' cultural. Suas relações com a bacia do Paraná e o Sul mato-grossense" in CARNEIRO DA CUNHA, Manuela (org). 1992 História dos índios no Brasil. São Paulo: Companhia das Letras/Secretaria Municipal de Cultura/FAPESP.

CAVALCANTI-SCHIEL, Ricardo. 2014. "Para além das terras altas e das terras baixas: modelos e tipologias na etnologia sul-americana” in Revista de Antropologia v. 57, n. 2 .

CHATÊLET, François. 1974. História da Filosofia (8 vols.). Rio de Janeiro: Zahar.

CLASTRES, Pierre. 1974. La société contre l'État: Recherches d'anthropologie politique. Paris: Éditions de Minuit.

[1974] 2003. A sociedade contra o Estado: pesquisas de antropologia política. São Paulo: Cosac Naify. "Copérnico e os selvagens" pp. 23-41; “Troca e poder: filosofia da chefia indígena" pp. 45-63; "O arco e o cesto" pp. 119-143; "Do Um sem o Múltiplo" pp. 187- 191; "Da tortura nas sociedades primitivas" pp. 195-204; “A sociedade contra o Estado” pp. 207-234.

[1980] 2004. Arqueologia da Violência: pesquisas de antropologia política. São Paulo: Cosac Naify. "Liberdade, mau encontro, inominável" pp. 145-162; "A economia primitiva" pp. 165-183; "Arqueologia da violência: a guerra nas sociedades primitivas” pp. 215-253; "Infortúnio do guerreiro selvagem” pp. 255-297.

CLIFFORD, James. 2002. A experiências etnográfica: antropologia e literatura no século $X X$. Rio de Janeiro: Editora UFRJ.

COELHO DE SOUZA, Marcela. 2004. "Parentes de Sangue: incesto, substância e relação no pensamento Timbira" in Mana v. 10, Rio de Janeiro.

COLINI, G. A. 1975. "Notícia histórica e etnográfica sobre os Guaicuru e os Mbayá" in BOGGIANI, Guido Os caduveos. Belo Horizonte, Editora Itatiaia.

COMBÈS, Isabelle, LOWREY, Kathleen \& VILLAR, Diego. 2009. "Comparative studies and the South American Gran Chaco" in Tipití v. 1 n. 1, pp. 69-102.

CORRADINI, Cirlene Moreno. 2007. Os Guaicuru-Kadiwéu no contexto da Guerra do Paraguai: fronteiras, relações interétnicas e territorialidade. Maringá: Universidade Estadual de Maringá (Dissertação de Mestrado em História).

2014. "A presença dos Guaikuru, ancestrais kadiwéu, na Guerra do Paraguai (1864-1870)" in Kadiwéu: senhoras da arte, senhores da guerra. Curitiba: Editora CRV, pp. 62-83.

CUNHA, Antônio Geraldo da. 2010. Dicionário etimológico da língua portuguesa. 4.ed.revista pela nova ortografia. Rio de Janeiro: Lexikon.

DA MATTA, Roberto. 1976. Um mundo dividido: a estrutura social dos índios Apinayé. Petrópolis: Editora Vozes.

DESCOLA, Philippe. 1996. "Constructing natures: symbolic ecology and social practice" in DESCOLA, P. \& PALSON, G. (Orgs.). Nature and Society: anthropological perspectives. Londres: Routlege, pp. 82-102.

DÉSY, Pierrette. 1993. "The Berdaches: 'Man-Woman in North-America” in Classiques des Sciences Sociales - UQAC. Disponível em 
http://classiques.uqac.ca/contemporains/desy_pierrette/the_berdaches/desy_the_ber daches_pp.pdf. Último acesso em 21/07/2017.

DRAGO, André. 2012. Formas políticas ameríndias: etnologia jê. São Paulo, Universidade de São Paulo (Dissertação de Mestrado em Antropologia Social).

DUMONT, Louis. 2008. Homo Hierarchicus: o sistema das castas e as suas implicações. São Paulo: Edusp.

DURAN, Maria Raquel da Cruz. 2016. "Leituras antropológicas sobre a arte kadiwéu" in Cadernos de Campo v. 24, pp. 43-70.

2017. Padrões que conectam: o Godidigo e as redes de socialidade kadiwéu. Manuscrito inédito.

ENRIQUEZ, Eugène. 2014. "O trabalho, essência do homem? O que é trabalho?” in Cadernos de Psicologia Social do Trabalho v. 17, pp. 163-176.

FARON, Louis e STEWARD, Julian. 1959. Native Peoples of South America. New York: McGraw-Hill.

FAUSTO, Carlos. 1992. "Fragmentos de História e Cultura Tupinambá: da etnologia como instrumento crítico de conhecimento etno-histórico" in CARNEIRO DA CUNHA, Manuela (org), História dos índios no Brasil. São Paulo: Companhia das Letras, pp. 382-396.

Amazônia” in Mana v. 8 n. 2, pp. 7-44.

FERNANDES, Florestan. 2006. A função social da guerra na sociedade tupinambá. São Paulo: Ed. Globo.

2009. "Um balanço crítico da contribuição etnográfica dos cronistas" in A investigação etnológica no Brasil e outros ensaios. São Paulo: Global, pp. 198-290.

FORTES, Meyer. 1983. "Rules and the emergence of society" in Royal Anthropological Institute of Great Britain and Ireland v. 39, pp. 1-52.

FRANCO, Patrick Thames. 2011. "Os Terena, seus antropólogos e seus Outros". Brasília: Universidade de Brasília (Dissertação de Mestrado em Antropologia Social).

GALEANO, Eduardo. 2016. El cazador de historias. Buenos Aires: Siglo Veintiuno Editores Argentina.

GALlOIS, Dominique Tilkin (org.). 2005. Redes de relações nas Guianas. São Paulo: Associação Editorial Humanitas. "Introdução: percursos de uma pesquisa temática", pp. 7-22.

GOLDMAN, Irving. 1963. The Cubeo: Indians of Northwest Amazon. Urbana, The University of Illinois Press.

GOLDMAN, Marcio. 1994. Razão e diferença: afetividade, racionalidade e relativismo no pensamento de Léry-Bruhl. Rio de Janeiro: Editora UFRJ.

GORDILLO, Gastón. 2006. "El Gran Chaco en la historia de la antropología argentina" in GORDILLO, Gastón. El Gran Chaco: Antropologías e historias. Buenos Aires: Prometeo Libros, pp. 225-320.

GUERREIRO Jr., Antônio. 2012. Ancestrais e suas sombras: uma etnografia da chefia kalapalo e seu ritual mortuário. Brasília: Universidade de Brasília (Tese de Doutorado em Antropologia Social). 
HERBERTS, Ana Lucia. 1998. Os Mbayá-Guaikurú: área, assentamento, subsistência e cultura material. São Leopoldo: Universidade Vale do Rio dos Sinos (Dissertação de Mestrado em História).

2011. "Panorama histórico dos Mbayá-Guaikuru entre os séculos XVI e XIX” in JOSÉ DA SILVA, Giovani (org.), Kadiwéu: Senhoras da arte, senhores da guerra. Curitiba: Editora CRV, pp. 17-47.

ILLICH, Ivan. 1973. A convivencialidade. Lisboa: Publicações Europa-América.

JOSÉ DA SILVA, Giovani. 2004. A construção física, social e simbólica da Reserva Indígena Kadiwéu: memória, identidade e história. Mato Grosso do Sul: Universidade de Mato Grosso do Sul (Dissertação de Mestrado em História).

2011. "A reserva indígena Kadiwéu (1899 - 1894): demarcações e conflitos pela posse de terra”, in José da Silva, Giovani (org.) Kadiwéu: senhoras da arte, senhores da guerra. Curitiba: Editora CRV, pp. 50-72.

Curitiba: Editora CRV.

(org.). 2011. Kadiwéu: Senhoras da arte, senhores da guerra.

JOSÉ DA SILVA, Giovani \& KOK, Maria da Glória Porto (org.). 2014. Kadiwéu: Senhoras da arte, senhores da guerra v. II. Curitiba: Editora CRV.

LA BOÉTIE, Etienne. [1571] 1987. Discurso da servidão voluntária. São Paulo: Editora Brasiliense.

LATOUR, Bruno. 1994. Jamais fomos modernos: ensaio de antropologia simétrica. Rio de Janeiro: Editora 34.

LEA, Vanessa. 1994. "Gênero feminino Mebêngôkre (Kayapó): desvelando representações desgastadas" in Cadernos Pagu v. 3. 2012. Riquezas intangíveis de pessoas partíveis: os Mabêngôkre (Kayapó) do Brasil Central. São Paulo: EdUSP.

LECZNIESKI, Lisiane. 2005. Estranhos laços: presação e cuidado entre os Kadiwéu. Florianópolis: Universidade Federal de Santa Catarina (Tese de Doutorado em Antropologia Social).

LÉVI-STRAUSS, Claude. 1993. História de lince. São Paulo: Companhia das Letras. 1994. Saudades do Brasil. São Paulo: Companhia das Letras.

Letras. "Parte V-Cadiueu" "Nalike", pp. 163-210.

2012. Antropologia Estrutural. São Paulo: Cosac Naify, “A noção de arcaísmo em Etnologia” pp. 149-173; "As organizações dualistas existem?” pp. 193-234; “O desdobramento da representação nas artes da Ásia e da América” pp. 347-387.

LIMA, Tania Stolze. 2002. O que é um corpo? in Religião e Sociedade v. 22, n. 1.

Paulo: Editora Unesp.

2005. Um peixe olhou para mim: o povo Yudjá e a perspectiva. São

LOLLI, Pedro. 2010. As redes de trocas rituais dos Yuhupdeh no igarapé Castanha, através dos benzimentos (mihdiid) e das flautas Jurupari (Ti').São Paulo: Universidade de São Paulo (Tese de Doutorado em Antropologia Social).

LOPES, Sônia. 1999. Bio. São Paulo: Editora Saraiva. 
LOWIE, Robert. 1948. "Social and Political Organization of the Tropical Forest and Marginal Tribes" in Steward, Julien (ed.), Handbook of South American Indians, v. 5. Washington D.C.: Government Printing Office, pp. 313-350.

LOWREY, Kathleen. 2006. "Entre estructura y historia: el Chaco" in COMBÈS, Isabelle (org.), Definiciones étnicas, organización social y estrategias políticasen el Chaco y la Chiquitania. Santa Cruz de la Sierra: Actes et Mémoires de l'Institute Français d'Études Andines, pp. 25-34.

MÃE, Valter Hugo. 2012. Ofilho de mil homens. São Paulo: Cosac Naify.

MAUSS, Marcel. 2003. Sociologia e Antropologia. São Paulo: Cosa Naify. "Ensaio sobre a dádiva: forma e razão da troca nas sociedades arcaicas", pp.183-314; "Ensaio sobre as variações sazonais das sociedades esquimós: estudo de morfologia social”, pp. 425-505.

MAZZARIELLO, Carolina \& BULGARELLI, Lucas. 2015. "Gênero" in Enciclopédia de Antropologia. Disponível em : http://ea.fflch.usp.br/conceito/gênero. Último acesso em 20 julho/2017.

McCALLUM, Cecília. 1998. “O corpo que sabe: da epistemologia kaxinawá para uma antropologia médica das terras baixas sul-americanas” in ALVEZ, PC \& RABELO, MC (orgs.), Antropologia da saúde: traçando identidade e explorando fronteiras [online]. Rio de Janeiro: Editora FIOCRUZ; Rio de Janeiro: Editora Relume Dumará. ISBN 85-7316-151-5. Available from SciELO Books http://books.scielo. org.

Oxford: Berg.

2001. Gender and sociality in Amazonia: How real people are made.

McCARTHY, Frederik D. \& McARTHUR, Margaret. 1960. "The food quest and the time factor in aboriginal economic life" in MOUNTFORD, C. P. (org.) in Records of the Australian-American Scientific Expedition to Arhem Land. Melbourne: Melbourne University Press v. 2, pp. 145-195.

MELATTI, Julio Cesar. 1979. "The relationship system of the Krahó” in MAYBURYLEWIS, David (Ed.), Dialectical Societies: The Ge and Bororo of Central Brazil. Cambridge: Harvard University Press, pp. 46-79.

MENGET, Patrick. 1985. "Jalons pour une étude comparative" in Journal de la Société des Americanistes v. 71, pp. 131-141.

MÉTRAUX, Alfred. 1946. "Ethnography of the Chaco", in STEWARD, Julien (ed.), Handbook of South American Indians: The Marginal Tribes, v. I. New York, Cooper Square Publishers, pp. 197-370.

MORGAN, Lewis. 1891. League of the Ho-de'-no-sau-nee or Iroquois. New York: Sage \& Brother Publisher.

OAKDALE, Suzanne. 2008. "The commensality of 'contact', 'pacification', and interethnic relations in the Amazon: Kayabi autobiographical perspectives" in Journal of the Royal Anthropology Institute v. 14, pp. 791- 807.

ORTNER, Sherry. [1972] 1979. "Está a mulher para a natureza assim como o homem está para a cultura?" in ROSALDO, Michelle. A mulher, a cultura e a sociedade. Rio de Janeiro: Paz e Terra, pp. 95-120.

OULHEN, Nathalie, SCHULZ, Barbara e CARRIER, Tyler. 2016. "English translation of Heinrich Anton de Bary's 1878 speech, 'Die Erscheinung der Symbiose' ('De la symbiose')" in Symbiosis v. 69, pp. 131-9. 
OVERING, Joanna. 1999. "Elogio do cotidiano: a confiança e a arte da vida social em uma comunidade amazônica” in Mana v. 5 n. 1, pp. 81-107.

PADILHA, Solange. 1996. A arte como trama do mundo: corpo, grafismo e cerâmica Kadiwéu. Brasília: UnB (Dissertação de Mestrado).

PECHINCHA, Mônica. 1994. Histórias de admirar: mito, rito e história kadiwéu. Brasília: Universidade de Brasília (Dissertação de Mestrado em Antropologia Social).

PEDROSO, Diego Rosa. 2013. “Quem veio primeiro?”: Imagens da hierarquia no Uaupés (Noroeste Amazônico). São Paulo: Universidade de São Paulo (Dissertação de Mestrado em Antropologia Social).

PERRONE-MOISÉS, Beatriz. 1992. "Índios livres e índios escravos: os princípios da legislação indigenista do período colonial (séxulos XVI a XVIII)” in M. Carneiro da Cunha (org), História dos índios no Brasil. São Paulo: Companhia das Letras, pp. 115132.

2000. "Aldeados, aliados, inimigos e escravos: lugares dos índios na legislação portuguesa para o Brasil” in Actas (v.1) do congresso PortugalBrasil: Memórias e Imaginários (1999, Lisboa). Lisboa: GTMECDP, pp.147 164

2003. "O estudo do político entre os indígenas americanos: alguns marcos teóricos e metodológicos". Relatório de Pesquisa (Proc. FAPESP 02/04041-9) Ms.

2006. "O mistério das confederações". Comunicação simpósio "Guiana ameríndia: etnologia e história", Belém, Ms. Disponível em Academia.edu

2008. "L'alliance normando-tupi au XVIe siècle: la célébration de Rouen” in Journal de la Société des Américanistes, v. 94, n. 1, pp .45 - 64

2012. "Bons chefes, maus chefes, chefões: elementos de filosofia política ameríndia" in Revista de Antropologia v. 54, n. 2.

2014. "Performing alliances and performative identities. Tupinamba in the Kingdom of France”. In: G. G. Penny \& L. Graham (eds.) Performing Indigeneity: Global Histories and Contemporary Experiences. Lincoln/London: University of Nebraska Press, pp 110-135.

Paulo: Tese de Livre-Docência.

2015. Festa e Guerra. São Paulo, Universidade de São

PERRONE-MOISÉS, Beatriz \& LOLLI, Pedro. 2017. "A ilusão hierárquica nas Américas". Ms.

PERRONE-MOISÉS, Beatriz \& SZTUTMAN, Renato. 2010. "Notícias de uma certa confederação tamoio" in Mana v. 16, n. 2, pp. 401-433.

PERUSSET, Macarena \& Rosso, Cintia. 2009. "Guerra, canibalismo y venganza colonial: los casos mocoví y guaraní” in Memoria Americana v. 17 n. 1, pp. 61-83.

PETSCHELIES, Erik. 2012. O Carcará e o Cristo: transformações kadiwéu. Campinas: Universidade de Campinas Dissertação de Mestrado em Antropologia Social).

PIMENTEL, Spensy Kmitta. 2012. Elementos para uma teoria política kaiowá e guarani. São Paulo: Universidade de São Paulo (Tese de Doutorado em Antropologia Social).

RADIN, Paul. 1946. Indians of South America. New York: Doubleday \& Company, Inc. 
RAMOS, Alcida Rita. 1980. Hierarquia e simbiose: relações intertribais no Brasil. Brasília: HUCITEC.

RIBEIRO, Darcy. 1980a. Kadiwéu: ensaios etnológicos sobre o saber, o azar e a beleza. Rio de Janeiro: Petrópolis.

1980b. "Sistema familial kadiwéu" in Uirá sai à procura de Deus: ensaios de etnologia e indigenismo. Rio de Janeiro: Paz e Terra.

RICHARD, Nicolás. 2008. Les chiens, les hommes et les étrangers furieux. Archéologie des médiations indiennes dans le Chaco boreal. 2 vol. Paris: École des Hautes Études en Sciences Sociales (Tese de doutorado).

2011. "La querelle des noms. Chaînes et strates ethnonymiques

dans le Chaco borea”l in Journal de a Société des Américanistes, v. 97, n. 2, pp. 201-230.

RICHARD, Nicolás \& COMBÈS, Isabelle. 2015. "O complexo alto-paraguaiense: do Chaco a Mato Grosso do Sul” in CHAMORRO, Graciela \& COMBÈS, Isabelle (Org.), Povos indígenas em Mato Grosso do Sul: História, cultura e transformações sociais. Dourado: UFGD, pp. 231-248.

RIVAL, Laura. 1998. "Androugynous parentes and guest children: the Huaroni couvade" in Journal of the Royal Anthropological Institute v. 4, pp. 423-435.

RODRIGUES, Valéria Nogueira. 2009. "Os índios Kadiwéu no séxulo XIX: alteridade, identidade e transculturação”. Mato Grosso: Universidade Federeal de Mato Grosso (Dissertação de Mestrado em História).

SAHLINS, Marshall. 1972. Stone Age Economics. Chicago: Aldine Publishing Company. 2004. "A sociedade afluente original" in Cultura na Prática. Rio de Janeiro: Editora UFRJ, pp. 105-151.

SANTOS, Lucas Keese dos. 2016. A esquiva do xondaro: movimento e ação política entre os Guarani Mbya. São Paulo, Universidade de São Paulo (Dissertação de Mestrado em Antropologia Social).

SANTOS-GRANERO. Fernando. 2009. Vital enemies: slavery, predation and the Amerindian Economy of Life. Austin: University of Texas Press.

2016. "Masters, slaves and real people: native understandings of ownership and humaneness in Tropical American Capturing Societies" in BRIGTMAN, Marc; FAUSTO, Carlos \& GROTTI, Vanessa (ed.) Ownership and nurture: studies in native Amazonian property relations. New York: Oxford, Berghan Books.

SCHWARCZ, Lília Moritz \& PEDROSA, Adriano (org.). 2015. Histórias mestiças: catálogo. Rio de Janeiro: Cobogó; São Paulo: Instituto Tomie Ohtake.

SEEGER, Anthony. 1980. Os índios e nós. Rio de Janeiro: Ed. Campus. "O significado dos ornamentos corporais" pp. 43-57; "Corporação e corporalidade: ideologia de concepção e descendência” pp.127-132.

1981. Nature and society in central Brazil: The Suya Indians of Mato Grosso. Cambridge: Harvard University Press.

SEEGER, A. DA MATTA, R. \& VIVEIROS DE CASTRO, E. B. 1979. A construção da pessoa nas sociedades indígenas brasileiras in Boletim do Museu Nacional, Série Antropologia, n. 32, pp. 1-49. 
SIQUEIRA JR, Jaime. 1992a. Arte e técnica kadiwéu. São Paulo: Secretaria de Cultura. 1992b. "A iconografia kadiwéu atual” in VIDAL, Lux (org.)

Grafismo indígena: estudos de antropologia estética. São Paulo: EdUSP. 1993. Essa terra custou o sangue de nossos avós: a construção do tempo e espaço Kadiwéu. São Paulo: Universidade de São Paulo (Dissertação de Mestrado em Antropologia Social).

STERPIN, Adriana. 1993. "La chasse aux scalps chez les Nivacles du Grand Chaco" in Journal de la Societé des Américanistes v. 79, n. 1, pp. 33-66.

SUSNIK, Branislava. 1971. El indio colonial del Paraguay v. 3. Asunción: Museo Etnografico Andres Barbero.

1972. Dimensiones migratorias y pautas culturales de los pueblos del Gran Chaco y de su periferia (enfoque etnológico). Asunción: Universidad Católica Nuestra Señora de la Asunción.

Etnografico Andres Barbero.

1978. Los aborigenes del Paraguay,v. 3. Asunción, Museo

STEWARD, J. (ed.). 1946. Handbook of South American Indians: The Marginal Tribes, v. I. New York, Cooper Square Publishers.

STRATHERN, Marylin. 1997. "Entre uma melanesista e uma feminista" in Cadernos Pagu v. 8, n. 9, pp. 7-49.

2006. O gênero da dádiva. Campinas: Editora da Unicamp.

SZTUTMAN, Renato. 2005. O Profeta e o Principal: A ação política ameríndia e seus personagens. São Paulo: Universidade de São Paulo (Tese de doutorado).

2012. O Profeta e o Principal: A ação política ameríndia e seus personagens. São Paulo: Editora da Universidade de São Paulo.

TESTART, A. 1998. "L'esclavage comme institution” in L'Homme v. 145, pp. 31-69.

TURNER, Terence. 1966. Social structure and political organization among the Northern Kayapó. Harvard (Tese de Doutorado).

TOLA, Florencia Carmen. 2007. “Eu não estou só(mente) em meu corpo'. A pessoa e o corpo entre os Toba (Qom) do Chaco argentino" in Mana v. 13, n. 2, pp. 499-519.

. 2010. "Una revisión de los etnónimos de los Toba (Qom) del Chaco argentino em función de la categoria de 'persona' y de la 'vida social”' in Publicar v. IX, pp. 167-181.

2012a. To no estoy solo en mi cuerpo: cuerpos-personas múltiples entre los qom (toba) del Gran Chaco. Buenos Aires: Biblos/Culturalia.

superpoblado" in Indiana v. 29, pp. 308-328.

2012b. "El cuerpo multiple qom en un universe 2013. "Introducción. Acortando disatancias: El Chaco, la antropología y la antropología del Gran Chaco" in Ontologia, poder, afectividad. Buenos Aires: Rumbo Sur, Colección etnográfica, pp. 11-37.

VIDAL, Lux. 1992. "A pintura corporal e arte gráfica entre os Kayapó-Xikrin do Cateté" in VIDAL, lux (org.), Grafismo indígena: estudos de antropologia estética. São Paulo: EdUSP, pp. 143-189. 
VILAÇA, Aparecida. 2002. "Making kin out of others in Amazonia" in Journal of the Royal Anthropological Institute v. 8, pp. 347-365.

2005. "Chronically unstable bodies: reflections on amazonian corporalities" in Journal of the Royal Anthropological Institute v. 1 1, pp. 445-464.

VILLAR, Diego \& CÓRDOBA, Lorena. 2010. "Relaciones interetnicas, etnonimia y espacialidade: el caso de los panos meridionales" in Boletín Americanista v. 60, pp 33-49.

VITAR, Beatriz. 2001. "Las mujeres chaqueñas en las reducciones fronterizas del Tucumán: entre la tradición y el cambio (siglo XVIII)" in Anuario IEHS: Instituto de Estudios Historicos y Sociales v. 16.

. 2015. "La subversión del orden jesuítico: las ancianas indígenas y su resistencia a la acción misionera en el Chaco" in Missões: Revista de Ciências Humanas, v. 1 n. 1.

VIVEIROS DE CASTRO, E. B. 1979. "A fabricação do corpo na sociedade xinguana" in Boletim do Museu Nacional, Série Antropologia, n. 32, p. 40-49.

Antropológico v. 81, pp. 252-262.

1983. "Hierarquia e simbiose em questão" in Anuário

1996. "Os pronomes cosmológicos e o perspectivismo ameríndio” in Mana v. 2 n. 2, pp. 115-144.

2002. A inconstância da alma selvagem. São Paulo: Cosas Naify. "O mármore e a murta: sobre a inconstância da alma selvagem”, pp. 183264; "Imanência do inimigo"pp. 267-294; "Imagens da natureza e sociedade", pp. 319344; "Perspectivismo e multinaturalismo na América indígena", pp. 347-399; “Atualização e contraefetuação do virtual: o processo do parentesco", pp. 403-455.

2004. "Posfácio: O intempestivo, ainda" in P. Clastres, Arqueologia da violência: pesquisas de antropologia política. São Paulo: Cosac Naify, pp. 301-366.

2014. "O antropólogo contra do Estado" in Revista Piauí, ed. 88. Rio de Janeiro: Editora Abril. Entrevista concedida a Rafael Cariello.

WAGNER, Roy. 2010. “Exitem grupos sociais nas terras altas da Nova Guiné?” in Revista Cadernos de Campo v. 19, pp. 237-257. Tradução de Iracema Dulley.

WEBER, Max. [1905] 2004. A ética protestante e o espírito do capitalismo. São Paulo: Companhia das Letras. 


\section{Anexos}

$I^{1}$.

BalaGadioGoxia era capitão aqui da aldeia de índio Kadiwéu. Ele sabia caçar, ele matava bicho, em todas estas caçadas dos homens, ele sabia tudo. Os Kadiwéu acharam falta dele e resolveram ir atrás. Mas não era para pegar filho do Kayowá, era para trazê-lo novamente. De repente, os Kadiwéu viram BalaGadioGoxia vindo pelo caminho. Ele trouxe aquele cocar (laleı). Índio Kadiwéu não conhecia o cocar. Eles não faziam, era serviço de Kayowá. O cabelo de BalaGadioGoxia já tinha coisa tão bonita. E trouxe também a saia, mesma coisa que o cocar.

$\mathrm{II}^{2}$.

Dois patrícios eram muito amigos, um deles morreu, o outro ficou triste e, de noite, foi dormir no cemitério. Ficou por lá uns três dias, mas nunca encontrava o amigo.

Uma noite ele veio, acordou aquele patrício e perguntou o que queria. Ele respondeu que estava triste, por isso tinha ido ao cemitério. O morto não falou nada, porque pensava que o outro é que tinha morrido. Quando morre uma família inteira, ficam todos juntos outra vez, nem sabem que morreram; quando morre um só ele fica chorando sozinho, pensa que os outros é que morreram.

Aquele homem ficou junto com os mortos, andando com eles por ali.

Um dia saíram para caçar, o companheiro deu um cavalo para aquele patrício montar e disse:

- Nós vamos caçar veado branco, mas cuidado, você não pode bater nesse cavalo.

Eles foram, quando estavam no campo o homem viu um veado e já saiu correndo atrás, esqueceu de tudo e bateu no cavalo que virou esqueleto, caiu ali mesmo o couro, como cinza.

O companheiro foi adiante, matou um veado branco, carneou e trouxe a carne na garupa. Mas para eles os cupins já são servos e veados, e a carne é esta folha de paineira que é muito vermelha. Quando juntaram, o patrício disse:

- Ô, já estou sem montada. - E o morto respondeu:

- Eu não falei pra não bater. - e foram adiante.

Aquele homem voltou pra contar como era lá, por isso nós sabemos. Depois ele foi outra vez andar com os mortos.

\footnotetext{
${ }^{1}$ Pechincha (1994: 157).

${ }^{2}$ Ribeiro (1980a: 117).
} 
Um dia o companheiro mostrou uma moça bonita, toda cheia de fitas e cor e disse:

- Eu quero que você case com aquela moça lá, é bem bonita.

O patrício foi falar com a mãe e o pai da moça, depois casou. De noite ela estava ali junto e o homem que era vivo falou: - "Vamos...?".

Ela perguntou de que o homem estava falando; o homem repetiu:

- Pois nós não vamos...? - e foi passando o braço para abraçar a moça, mas não achou carne e não pôde abraçar nada. A mulher perguntou:

- Que é isso, passarinho?

Lá eles esqueceram toda safadeza, não têm malícia nenhuma.

Aquele homem voltou pro meio de nossa gente, mas morreu logo. Tudo o que comia, vomitava, foi emagrecendo até que morreu mesmo.

III $^{3}$.

O mito conta a história de Nitikana, mas a história se inicia antes de seu nascimento.

A mãe de Nitikana teve uma primeira filha, que chamou de Ebecalowai. Certo dia, a mãe levou-a para banhar no rio. De repente, formou-se uma grande onda que veio em sua direção.

A onda falou: eu vim para buscar a sua filha. Eu vou batizar a sua filha (eiomaiowaie Gadiona). A mãe, assustada, não se moveu para proteger a filha, que a onda levou para sempre.

Quando nasceu Nitikana, seus pais disseram que ninguém a tiraria de seus braços. 'Eu vou cuidar bem da minha filha, eu não vou deixar que ninguém roube de mim esta minha filha, a mãe falou. A WimaGalo não vem buscar minha filha, ela não pode roubar, porque a menina está aqui nos meus braços quando eu durmo'. O pai da Nitikana sempre fazia fogo ali, para espantar a WimaGalo.

Mas, quando a Nitikana estava com três dias, a WimaGalo veio pegá-la. WimaGalo, a lobinho, é uma ladra que gosta de pegar crianças e todos a temem. Ela veio de noite e levou a Nitikana para o mato.

Os pais e avós da menina estavam desesperados quando ouviram o seu choro longe da casa, e foram buscá-la.

\footnotetext{
${ }^{3}$ Pechincha (1994: 95-100).
} 
Quando já estava grandinha, Nitikana some uma segunda vez. Quando voltou, a menina trouxe consigo dois sapos, cujos nomes eram Liwidipi e Awaditaa. Nitikana pediu para sua mãe fazer um pote de barro onde guardou os sapos.

Nitikana já havia crescido mais e, num dia em que estava chovendo forte, desapareceu no meio da chuva. Nitikana tinha uma pequena escrava Xamakôko que sempre a acompanhava. A mãe de Nitikana mandou aquela escrava ir procurar a sua filha. Quando a encontrou, Nitikana estava de cócoras, cercada de muitos presentes, uma bolsa, cujo uso os índios ainda desconheciam, e muitos colares, que ganhou do pássaro Edigidigi.

Nitikana já estava mocinha e se perdeu novamente. Um velho que foi buscar lenha ouviu um barulho, seguiu na sua direção e encontrou Nitikana. Ela estava sentada, segurando uma grande taquara, grossa e comprida, que se estendia ao alto até perder de vista. A taquara, ou dinebacawedaGa, saía do chão, passando por entre as pernas da moça. Quando ficaram sabendo, os pais da Nitikana começaram a convidar os parentes para ir buscá-la, tal como hoje se convida para uma festa. Muitos homens combinaram fazer uma roda para cercar a moça e ver o que ela estava fazendo. Mas a taquara não estava mais com ela e, quando os homens perguntaram por tal objeto, Nitikana negou que o houvesse segurado.

Quando Nitikana ficou moça grande, ela se perdeu novamente e ninguém pôde mais encontrá-la. Certo dia, Nitikana sentiu uma coisa na sua barriga e começou a apalpá-la: 'o que é esta coisa dura dentro da minha barriga? O que aconteceu? Será que é assim que uma mulher fica grávida? Mas eu nem tenho marido...' Nitikana deitou-se numa areia e, de repente, começou a ouvir um barulho. Era o sapo Ilaceki que vinha. Ele lhe disse: 'eu trouxe aniwiGate idinanamaGane, porque você vai dar à luz'. A niwi Gate é uma manta de algodão para enrolar o filho da Nitikana. A moça começou a sentir as dores do parto e a criança nasceu ao meio-dia.

De repente Nitikana ouviu a voz de uma mulher chamando-a. Era o Sol, que falou: 'eu sou o Sol. Eu vou batizar o seu filho, eu vou dar-lhe um nome'. O nome de seu filho é NigaGenigi. Todos os que existiam no céu desceram para ver aquela criança. As estrelas desceram do céu em forma de muitas luzes coloridas, vermelho, verde, azul, e ficaram pairando ao redor da Nitikana.

Todos os bichos vieram ao lado da Nitikana e entregaram-lhe os seus nomes. E veio também o pai do guri, a onça-parda. A onça veio cantando, achou a criança deitada e cruzou-lhe por cima várias vezes. Beijou a criança, passou a língua em sua boca. Napalatece é o nome do pai do guri. Nikikana admirou-se: 'então o meu filho tem pai. O 
pai dele é onça. Onde que você veio desse meu jeito? Eu nunca o vi na minha presença? Agora veio, beijou meu filho, que é onça, filho de onça. Eu não sei o que eu tenho. Eu sou gente, mas agora virou tanta coisa, tanto bicho do meu lado'.

O lugar onde Nitikana pariu chamava-se Alawadi. A criança que teve era uma criança de admirar. Antes de sua mãe ter forças para andar, o menino sumiu no mato, foi embora. Nitikana acompanhou o seu filho e sumiu no mato com ele. A criança crescia rápido. Logo começou a usar um bodoque (nabalenigi). $\mathrm{O}$ menino matava e comia os pássaros crus, mas ele era uma pessoa.

No dia do aniversário do menino, uma pomba branca pousou em sua cabeça. O menino quis acertar a pomba com o bodoque. A pomba ficou nervosa e falou para o guri: 'O que você pensa de mim, seu bicho?' Em seguida, a pomba arrependeu-se e desculpou-se: 'você não é um bicho, se você fosse um bicho, seria coberto de pelos. Mas você não tem pelo, você tem cabelo na cabeça'. A criança ficou com muita vergonha das palavras da pomba, que perguntou se o menino conhecia os seus avós. O menino negou.

— Você sabe que é uma pessoa? — a pomba perguntou.

- Eu sei, respondeu o menino.

— Você está vendo a sua avó?

— Eu não a vejo.

— Lá está a sua avó. Está tecendo algodão. O seu avô está junto. Lá estão os seus parentes.

O menino tentou ver, mas não conseguiu. A pomba pousou de novo na sua cabeça, tirou uma pena e cutucou nos olhos da criança. Ela tirou muitas coisas dos olhos do menino, coisas que não o deixavam enxergar. E o menino pôde ver seus parentes. Mas não pôde escutar o que eles estavam dizendo. A pomba, então, ajeitou sua asa, tirou outra pena e limpou os ouvidos do menino. Tirou pedaço de pau, folha, muito lixo. E o menino pôde ouvir os seus parentes.

O menino ficou triste porque soube de seus parentes e queria conhecê-los. A sua mãe explicou-lhe: 'eu não sei, meu filho, porque veio na minha cabeça de fazer estas coisas. É porque eu quis fazer estas coisas de admirar as pessoas. Eu sou uma mulher tão sabida. É por isso que a gente está morando aqui nesta mata'. O menino pediu a sua mãe para voltar para a casa dos avós e ela decidiu ir. Nitikana pegou uma corda do mato (ewaloco) e amarrou o guri nas suas costas. Veio uma forte ventania fazendo muito barulho. Os sapos estavam cantando.

Nitikana mastigou a parte vermelha do caraguatá, cuspiu e dali surgiu um homem forte, o Ooloeoligi, que os guiou até a aldeia. 
Na aldeia havia um senhor que tinha só um filho. Ele disse: 'Lá vem a Nitikana, é a nossa oniniona (capitã)'. Ao chegarem, o Ookolanigo ameaçou dar socos em todo mundo e foi embora. Desde então, os índios brincam de "jogar soco".

Nitikana foi conversar com a sua mãe. O menino estava enrolado na manta sob o seu braço e começou a mexer. 'É bicho, não é igual a gente aquele filho dela'. A mãe da Nitikana perguntou-lhe o que era aquilo mexendo, e ela puxou o menino NigaGenigi e disse que era o seu filho. NigaGenigi era pequenininho e já estava andando, já estava falando, já sabia tudo.

NigaGenigi não queria comer nada da comida de seu povo. O seu avô foi buscar lenha para fazer fogo. O machado dele era de pedra. Daí ele bateu e machucou o pé, cortou e saiu sangue. O neto dele estava ali pequenininho, correu, pegou a perna do avô e lambeu o machucado. Comeu aquele vovô dele. O avô ficou triste. Não foi embora porque é filho. Mas ficou triste, ficou admirado: 'por que ele lambeu isso?' O avô disse para a Nitikana: 'Oh, minha filha, este seu filho, decerto ele come algum bicho, carne que não está cozida, não está assada'. Ela falou: 'Come, pai. Ele vai caçar e quando ele traz algum bicho já come sem assar, sem cozinhar'.

No outro dia, o avô fez reunião. Aquela capitãozada se reuniu toda. O avô falou: 'eu quero que o senhor me acompanhe. E o meu neto não quer comer nada, decerto come carne de gente'.

O informante explicou:

Bateu na outra tribo de índio, por isso que índio já gosta de bater no outro indiada, por causa desse exemplo. Então por isso mesmo que já tem esse exemplo. Fez esse exemplo. Por causa disso é que foram bater na outra tribo de indiada, para trazer qualquer um guri, para netinho dele comer. Aquele guri da Nitikana não quer comer nada. Pegaram gurizinho para ele assar e comer. Aí bateram na outra indiada para trazer a bóia do guri da Nitikana. Quando trazia aquele guri, matou, assou e guri comeu. Por isso que tem nome Legaxiwa (nome pessoal). É nome da munheca da gente. Pois é, a munheca, quando cuidou criança bastante para comer. Porque é o capitão que manda. A capitã é filha do capitão. Criançada para pegar legaxiwa. Aquele legaxiwa. Quando o avô chegou, o guri falou: "eu quero pegar aquele legaxiwa para comer, eu quero pegar munheca para comer". O avô trouxe carne assada, decerto, então quer pegar legaxiwa. Niwelanigi quer comer.

Quando o Niwelanigi tornou-se homem, já tinha virado gente, os seus patrícios vieram lhe pedir para deixar de andar no mato, para fazer "paragem", para fazer casa. Mas antigamente, índio usa somente casa feita com varinha. Não chovendo, podia amarrar, fechar, deixar guardada. Quando chovia, armava a barraca. Uma tenda feita de piri. É um capim que nasce d'água, daquele caninho. O índio vai costurando, e tem armação para fazer casa. Os índios foram buscar o "ossamento" da barraca de Niwelanigi. Uns foram jogando as varas para os outros. E ficou pronta a 
epalaGajoGotedice, o ossamento da casa de Niwelanigi. Armaram toda a casa: "agora vamos fazer reunião". Quando terminaram, de repente Niwelanigi encontrou uma mulher, que lhe falou:

— Você não me conhece?

— Não senhora, não a conheço, respondeu Niwelanigi.

- Você é meu irmão, você é meu caçula. Quantas pessoas você já matou? Quanta cabeça de gente você já matou?

— Eu? Não matei por enquanto ninguém, nenhum.

- Bom, então está certo, eu posso cantar a minha alegria porque nos encontramos? Eu posso cantar?

- Ah, como não, pode cantar, pode cantar.

Essa mulher chamava-se coruja, a Awiaje. Ela cantou contando que Niwelanigite comera gente quando pequenininho. Ele é o seu caçula, oloxuxege. Ela declarou na música que ele que iria receber todos do que matou e comeu.

Os conselhos de Niwelanigi:

Índios de outras nações (Terêna, Kayowá, Guaikurú, Guaraní etc.) vieram escutar a palavra de Niwelanigi, aprender as coisas. O caminho estava seco e, quando se aproximavam, todos viram aquela poeira (namocotege) que se levantava, e falavam:

'Niwelanigi, já vem nossa gente'.

A avó de Niwelanigi cantou porque "tudo vizinhado, tudo quanto é espécie de índio vinha chegando na casa de Niwelanigi. A avó cantou de tanta alegria".

O informante comenta:

Não sei, a gente não sabe, a gente não pode saber. Nós recordamos tudo o que a Nitikana fez, mas por causa que é nossa avó. Porque primeira gente que está dando isso. Eu, toda essa indiada aí somos netos de Niwelanigite. Primeira gente que tem capacidade era ele. Todos vieram até Niwelanigi, para saber do seu ensino. Eles vieram saber o que vão fazer. Niwelanigi reuniu todo o pessoal, criança, homem... Reuniu a todos para explicar as coisas perigosas.

No primeiro conselho, Niwelanigi determinou que a carne do caititu deveria ser cozida: 'esse caititu, você tem que comer cozido, porque ele vai fazer mal, porque não tem sangue. Você cozinha, come carne e toma sopa. E convida toda criança para comer junto. A gente comendo de qualquer jeito, não cozinhando, não comendo carne, não tomando sopa, vai tossir quando assustar com qualquer coisa, eh, eh, eh, como queixada'.

Niwelanigi proibiu-os de comer o veado mateiro. Quem teimasse e comesse ficaria estéril (os índios acreditavam que o veado mateiro não se reproduzia com facilidade). Só os velhos podiam comer, porque não havia mais perigo. 
Niwelanigi determinou que a carne do veadinho pururuca fosse comida cozida: 'e convida toda gurizada para eles comerem. E não fazendo isso que eu mandei que faça, se estranhou o que eu mandei fazer, você não cumprindo, você não tem simpatia. Comendo esse veado, aí você não tem simpatia nenhuma. Você pode comer, mas qualquer susto você vai correr, vai correndo, vai fazer assim de curva vai chegar bem ali no inimigo de novo'.

Niwelanigi prosseguiu: 'não vá comer a canela do veado, porque se você correr dá cãibra. Homem não pode comer tutano de qualquer bicho, porque se machucar não sai sangue'.

Niwelanigi deu conselho para moça. Quando vem a "primeira saúde" para a moça, ela não deve comer mel de jataí, porque é muito doce: 'o mel de jataí é bicho. Pode ver aquela abelha dele, é um bichinho, você comendo esse, olha, cuidado, vai te fazer mal. De repente vai, parece que está andando abelhada no rosto, mas não tem nada. Você comeu aquele, você não segue o meu conselho. Aí já está passando ruim, vai arruinar. É perigoso virar bicho também. Qualquer uma coisa de repente, parece que abelhada está ali'. A moça também não pode comer carne de ema: 'aquela ema, você não come antes dessa saúde. Se comer carne de ema, você vai imediatamente ficar como ema, vai virar bicho. Não vai comer bicho, alguma carne. Come namocoli, come bacuri, come palmito, come coco, come farinha.

Aquele é certo, até que você limpa. As mulheres não podem comer carne, só quando acaba, quando não vem mais. Senão, quando você morrer, você vai ficar como aquele bicho que você comeu'.

O informante comenta:

Niwelanigi falou para as mulheres. Por isso mesmo antigamente mulher, ela respeitava aquele exemplo. Quando dessa saúde, carne não come. Toda indiada têm medo de comer carne. Quando a mulher parir, enquanto não está boa, essa dona não come carne. Come alguma sopa, até ficar boa. Por causa daquele conselho.

Niwelanigi ensinou para os que estão de luto: 'quando falece algum parente, quando ficar de luto, até o teu cabelo crescer e vir outro cortar, você não come carne, e você não conversa também, respeita teu cabelo. Enquanto não cortar, não conversa, fica calmo, tem que respeitar o costume. Senão você vai ficar conversadeira, não sabe conversar, aquela ignorância, não sabe nada, é meio variada, porque não respeitou aquele costume'. 